\title{
Structural changes in the cardiac interstitium following myocardial infarction : focus on the renin- angiotensin-system and the sympathetic nervous system
}

Citation for published version (APA):

Kuizinga, M. C. (1999). Structural changes in the cardiac interstitium following myocardial infarction : focus on the renin-angiotensin-system and the sympathetic nervous system. [Doctoral Thesis, Maastricht University]. Universiteit Maastricht. https://doi.org/10.26481/dis.19990312mk

Document status and date:

Published: 01/01/1999

DOI:

10.26481/dis.19990312mk

Document Version:

Publisher's PDF, also known as Version of record

\section{Please check the document version of this publication:}

- A submitted manuscript is the version of the article upon submission and before peer-review. There can be important differences between the submitted version and the official published version of record. People interested in the research are advised to contact the author for the final version of the publication, or visit the DOI to the publisher's website.

- The final author version and the galley proof are versions of the publication after peer review.

- The final published version features the final layout of the paper including the volume, issue and page numbers.

Link to publication

\footnotetext{
General rights rights.

- You may freely distribute the URL identifying the publication in the public portal. please follow below link for the End User Agreement:

www.umlib.nl/taverne-license

Take down policy

If you believe that this document breaches copyright please contact us at:

repository@maastrichtuniversity.nl

providing details and we will investigate your claim.
}

Copyright and moral rights for the publications made accessible in the public portal are retained by the authors and/or other copyright owners and it is a condition of accessing publications that users recognise and abide by the legal requirements associated with these

- Users may download and print one copy of any publication from the public portal for the purpose of private study or research.

- You may not further distribute the material or use it for any profit-making activity or commercial gain

If the publication is distributed under the terms of Article 25fa of the Dutch Copyright Act, indicated by the "Taverne" license above, 


\section{Structural changes in the cardiac interstitium following myocardial infarction}

Focus on the renin-angiotensin-system and the sympathetic nervous system 
Kuizinga, Marti $\mathrm{C}$.

Structural changes in the cardiac interstitium following myocardial infarction -

Focus on the renin-angiotensin-system and the sympathetic nervous system / Marti C. Kuizinga.

Elinkwijk BV Utrecht (drukwerk)

M. Y. Naerebout (omslag)

J.G.F. Beens jr., L. Nijland (layout)

Thesis Maastricht - with ref. - with summary in Dutch ISBN 90-9012465-9

Subject headings: myocardial infarction, remodeling, renin-angiotensin-system sympathetic nervous system

( 1999 M.C. Kuizinga, Maastricht, The Netherlands

All rights reserved. No part of this publication may be reproduced or transmitted in any form or by any means, electronic or mechanical, including photocopy, recording or any informationstorage or retrieval system, without permission in writing from the copyright owner. 


\section{Structural changes in the cardiac interstitium following myocardial infarction}

Focus on the renin-angiotensin-system and the sympathetic nervous system

\section{Proefschrift}

ter verkrijging van de graad van doctor, aan de Universiteit Maastricht,

op gezag van de Rector Magnificus, Prof. dr. A.C. Nieuwenhuijzen Kruseman volgens het besluit van het College van Decanen, in het openbaar te verdedigen op vrijdag 12 maart 1999 om 14.00 uur

door

Martina C. Kuizinga

geboren te 's Gravenhage op 12 maart 1961 


\section{Promotores:}

Prof. dr. M.J.A.P. Daemen

Prof. dr. J.F.M. Smits

\section{Beoordelingscommissie:}

Prof. dr. M. Borgers (voorzitter)

Prof. dr. J.W. Arends

Prof. dr. W. Schaper (Kerckhoff Institut, Bad Neuheim, Deutschland)

Prof. dr. H.A.J. Struijker Boudier

Prof. dr. K.T. Weber (University of Missouri, USA)

Financial support by

Netherlands Heart Foundation, grant 88224 and NWO/NHS grant 902-18-291

De Stichting Klinische Pathologie Zuid-Limburg

Disphar International B.V. te Hengelo is gratefully acknowledged. 
What a sigh is there!

The heart is sorely charged.

William Shakespeare, Macbeth, Act V-Scene I. 
Chapter 6: Effects of sympatholytic agents on DNA synthesis and collagen content in the rat heart after infarction

Introduction

Materials and methods $\quad 130$

Results

Discussion

References

Chapter 7: General discussion

\section{Introduction}

Remodeling and function - vascular growth and cardiac function early after myocardial infarction

Function of the $\mathrm{AT}_{2}$ receptor after myocardial infarction

Interference with sympathetic nervous system after MI

Implications and perspectives

References

Summary

Samenvatting

Curriculum vitae 


\section{Introduction}

\section{General introduction}

Heart failure is a very common syndrome in the Western world with an increasing incidence and prevalence'. In patients aged over 75 years, its prevalence is as high as $10 \%$. One of the major causes of heart failure is ischemic heart disease and acute myocardial infarction ${ }^{2.3}$. The syndrome results in significant morbidity and is a frequent cause of hospitalization. The clinical picture of heart failure includes signs and symptoms like dyspnea, orthopnea, pitting edema, pleural effusion, fatigue and weakness ${ }^{1}$. Moreover, heart failure is a progressive disorder eventually leading to death ${ }^{4}$. In the natural course of progressive heart failure, survival ranges between 6 months and 4 years, depending on the severity of heart failure'.

Despite recent advances in the management of heart failure, this disorder continues to be a major clinical problems. Obviously, understanding of the pathophysiology of heart failure is important for an adequate approach to therapy. To date, much research is focused on neurohormonal aspects and structural cardio- 
Chapter 6: Effects of sympatholytic agents on DNA synthesis and collagen content in the rat heart after infarction

Introduction

Materials and methods

Results

Discussion

References

Chapter 7: General discussion

Introduction

Remodeling and function - vascular growth and cardiac function early after myocardial infarction

Function of the $\mathrm{AT}_{2}$ receptor after myocardial infarction

Interference with sympathetic nervous system after MI

Implications and perspectives

References

Sumınary

Samenvatting 


\section{Introduction}

\section{General introduction}

Heart failure is a very common syndrome in the Western world with an increasing incidence and prevalence'. In patients aged over 75 years, its prevalence is as high as $10 \%$. One of the major causes of heart failure is ischemic heart disease and acute myocardial infarction ${ }^{2.3}$. The syndrome results in significant morbidity and is a frequent cause of hospitalization. The clinical picture of heart failure includes signs and symptoms like dyspnea, orthopnea, pitting edema, pleural effusion, fatigue and weakness ${ }^{1}$. Moreover, heart failure is a progressive disorder eventually leading to death ${ }^{4}$. In the natural course of progressive heart failure, survival ranges between 6 months and 4 years, depending on the severity of heart failure'.

Despite recent advances in the management of heart failure, this disorder continues to be a major clinical problems. Obviously, understanding of the pathophysiology of heart failure is important for an adequate approach to therapy. To date, much research is focused on neurohormonal aspects and structural cardio- 


\subsection{Dilatation}

Dilatation of the heart resulting in enlargement of the cavitary volume, has been shown to be an early ${ }^{22}$ and late event ${ }^{6,23,24}$ following experimental myocardial infarction. Similar findings were obtained in studies in humans ${ }^{25,26}$. The underlying structural mechanisms of ventricular dilatation following infarction concern sideto-side slippage of cells within the surviving tissue, resulting in a decreased number of cells across the ventricular wall ${ }^{22}$, myocellular elongation, as well as infarct expansion (see paragraph 2.3) ${ }^{23,27}$.

Dilatation of the heart can initially be considered to be a compensatory response to maintain stroke volume. On the other hand, dilatation also contributes to increased wall stress, which can further induce progressive chamber dilatation ${ }^{\circ}$. In fact, clinical studies have unequivocally shown that ventricular chamber dilatation is an important unfavorable prognostic factor after myocardial infarction ${ }^{28}$.

Risk lactors for cavity dilatation include sustained abnormal loading conditions associated witl large infarcts and infarct expansion, and the severity of the residual stenosis of the infarct-related coronary artery ${ }^{5.2 \% .30}$.

\subsection{Structural remodeling of the infarct}

Myocardial infarction results from reduction or arrest of a significant portion of the coronary flow leading to myocardial ischemic necrosis. In the infarcted area, myocyte necrosis and an acute inflammatory response at the border of the necrotic myocytes take place, followed by inflammation, fibroblast- and vascular cell proliferation, extracellular matrix deposition and resorption of necrotic tissue. This eventually results into scar formation ${ }^{31}$.

More recently it was suggested that myocyte programmed cell death (apoptosis of myocytes) was the major initial (as early as 2 hours after infarct induction) form of myocardial damage produced by occlusion of the main epicardial coronary artery in rats, whereas necrotic cell death followed apoptosis and contributed to the evolution of the infarct size $\mathrm{e}^{32}$. Apoptosis was largely limited to hypoxic regions during acute infarction ${ }^{33.34}$. Also in human infarcts extensive apoptosis occurred before neutrophilic infiltration was apparent ${ }^{35}$. During the healing phase of the infarction apoptosis has been reported to play an important role in the disappearance of both the infiltrated leucocytes and interstitial cell population in the infarct ${ }^{36}$ 
Changes in collagen metabolism in the infarcted segment have been subject of detailed investigation in the rat heart infarction model. Early after infarction (within hours) degradation of the collagenous network surrounding cardiomyocytes and capillaries in the infarct zone occurs ${ }^{37,38}$. Collagen fibers are broken down by the activation of collagenases and related enzymes. The breakdown of cardiac structure can lead to slippage of surviving myocytes and, in addition, to myocyte loss. This process may cause disproportionate dilatation and thinning of the infarct, also called 'infarct expansion' ${ }^{6,39}$. Infarct expansion is a risk factor for the development of ventricular aneurysm or even rupture and is associated with adverse effects on ventricular function and prognosis $\mathrm{s}^{40.41}$.

Scar formation is the net result of a delicate balance between collagen degradation and synthesis ${ }^{42}$. The expression of type I collagen gene is markedly enhanced in the infarct zone on day 3 and persists for 90 days ${ }^{43,44}$. Fibrillar collagen deposition can be observed by day $7^{45}$. Collagen degradation exceeds synthesis during the very early phase of infarction. Enhanced collagen degradation after myocardial infarction involves a family of matrix metalloproteinases (MMPs) which mediate degradation of fibrillar collagen ${ }^{38,46}$. In turn, the activity of metalloproteinases is controlled by a family of tissue inhibitors of metalloproteinases (TIMPS). Thus, the balance between collagenases (MMP) and TIMP-dependent inhibition ultimately determines the amount of collagenolysis in infarcted tissue $\mathrm{e}^{38}$.

Myofibroblasts (phenotypically transformed fibroblast-like cells) have been shown to be the predominant cell responsible for collagen fonmation at sites of repair in the rat heart ${ }^{4.44}$. These myofibroblasts were shown to remain in mature scar tissue ${ }^{47-48}$. Increases of both types I and III procollagen mRNA levels have been observed within a few days after infarct induction, followed by collagen deposition $^{\text {st }}$. The amount of other constituents of the extracellular matrix, like fibronectin and tenascin, also changes after the induction of an infarction ${ }^{50-52}$.

\subsection{Structural remodeling of the non-infarcted myocardium}

\section{- Cardiomyocytes}

Compensation for the loss of viable tissue after infarction entails myocyte hypertrophy in the non-infarcted myocardium ${ }^{53}$. Commonly used parameters of myocyte hypertrophy are (relative) cardiac weight measurements, evidence of protein synthesis and morphometric features. Myocyte hypertrophy is an early 
response and is apparent within the first week after infarction ${ }^{54}$. The hypertrophic response persists in the course following infarction and has been observed for months and years ${ }^{24.55-5 n}$. In addition to the left ventricle, the right ventricle as well as the transition zone bordering the infarction are also involved in the hypertrophic response ${ }^{5.45,58}$.

Myocyte hypertrophy after infarction is accomplished by addition of new sarcomere units in series with existing sarcomeres (eccentric hypertrophy due to volume overload), as well as parallel addition of filaments as cells increase in diameter (concentric hypertrophy due to pressure overload) ${ }^{54}$.

Hypertrophy early after infarction may be seen as an useful adjustment to loss of contractile tissue, by increasing the number of sarcomeres and by restoring wall stress in the infarcted ventricle ${ }^{11.54}$. This is in agreement with results from studies in which treatment with growth hormone started one day after infarct induction caused additional hypertrophy of the non-infarcted myocardium, reduction of left ventricular dilatation and improvement of cardiac function ${ }^{60}$. However, later on, the hypertrophic process may turn out to be imperfect. It provides benefit for a limited time only, and may ultimately lead to heart failure ${ }^{11.61}$.

Besides through hypertrophy, myocardial mass may also increase through an increase in cell number. For a long time the prevailing perception has been that cardiomyocytes are terminally differentiated cells and lose their ability to proliferate ${ }^{14,62,63}$. After birth, a rapid switch from myocyte hyperplasia to hypertrophy occurs between postnatal day 3 and $4^{64}$. In some species, including man, cardiomyocyte nuclei can replicate DNA without cell division which results in polyploid cells ${ }^{62}$. Other studies, however, have demonstrated that under certain conditions the adult ventricle has the reserve to activate DNA synthesis which may proceed to hyperplasia. In ischemic cardiomyopathy, re-activation of cardiomyocyte DNA synthesis and hyperplasia have been demonstrated ${ }^{65-67}$. Comparable observations have been done by van Krimpen et al ${ }^{68}$, reporting that a small percentage (about 1-2\%) of total DNA synthesis in the non-infarcted ventricle was present in cardiomyocytes. These results are in agreement with quantitative studies in hypertrophic human hearts ${ }^{69.70}$ and animal studies ${ }^{71.73}$.

Apoptosis is another reaction of cardiac myocytes to acute ischemic injury in the area bordering infarction, and in the remote areas of the surviving portion of the hear $\mathrm{t}^{74}$. Heart failure of either ischemic or non-ischemic origin was accompanied by a significant increase in myocyte apoptosis in the human heart ${ }^{75}$.

Not only cell size and number, but also the cellular phenotype may change. Cardiac hypertrophy secondary to infarction is associated with altered gene expression, especially genes of the fetal phenotype ${ }^{23,62}$. For example, a transition 
of the expression of the normally expressed fast contractile protein $\alpha$-myosin heavy chain $(\alpha-\mathrm{MHC})$ to the slower $\beta-\mathrm{MHC}$ results in a decreased capacity to develop contractile speed ${ }^{62,76}$. Such a change can be viewed to be adaptive, because of a lower energy and oxygen consumption of the cardiac muscle ${ }^{77}$. In addition, among others, expression of skeletal $\alpha$-actin, pre-proatrial natriuretic peptide (ppANP) mRNA was noted after infarction ${ }^{23,76}$.

Many other changes are part of the post-infarction remodeling process and include changes in calcium handling and alterations in enzymatic profiles (so-called biochemical remodeling) ${ }^{59,78,70}$

\section{- Extracellular matrix and interstitial cells}

The structural characteristics of the extracellular matrix are important for cardiac function. The collagen network is a major constituent for the preservation of myocardial architecture and chamber geometry and plays an integral role in global ventricular remodeling ${ }^{13.18}$. Fibrosis is defined as a disproportionate increase in myocardial collagen concentration ${ }^{18}$. Changes in collagen content might be considered, again, as beneficial as well as maladaptive. On the one hand, collagen deposition probably can serve an adaptive role in the initial response to overload, where increased wall stiffness can reduce dilatation and, as a consequence of the law of Laplace, lessen wall tension in the overloaded heart ${ }^{80}$. On the other hand, it has been shown that even small increases in the amount of collagen can cause adverse effects on diastolic relaxation and result in stiffness ${ }^{18,42.81 .82}$. Also, cardiac fibrosis is associated with arrhythmia ${ }^{83}$.

An early accumulation of fibrillar collagen in the non-infarcted region has repeatedly been observed following infarction ${ }^{24.68 .84}$. This increase in collagen seems not to be directly related to myocyte necrosis, but resembles the pattern of reactive fibrosis, characterized by thickening of the perimysium and occupation of intermuscular spaces by collagen fibers ${ }^{44}$. The elevation of collagen content in the non-infarcted septum is preceded by a 4 to 5 -fold increased production of type I and III procollagen mRNA until 21 days post-infarction ${ }^{44}$. Interstitial fibroblasts have been shown to be the source of fibrillar collagen production ${ }^{44}$.

Human infarcted hearts also showed a significantly higher collagen content than non-infarcted hearts ${ }^{56.85}$. Another study did not observe differences in collagen content in the non-infarcted human myocardium remote from the scar ${ }^{86}$. This different outcome can be due to the fact that all patients in that particular study had received ACE-inhibitors, known to decrease cardiac fibrosis ${ }^{87}$. 
The stimulus for collagen deposition is not exactly known, but potential candidates are e.g. angiotensin, aldosterone, growth factors like transforming growth factor- $\beta_{1}\left(\right.$ TGF- $\left.\beta_{1}\right)$ and catecholamines (vide infra) $)^{42,44,88}$.

Non-myocytes respond to myocardial infarction with transiently enhanced DNAsynthesis, which is maximum between 7 and 14 days after the infarct in both the non-infarcted septum and the right ventricle ${ }^{68}$. The vast majority (98 per cent) of DNA synthesis was found in the non-myocytes ${ }^{68}$. Similar findings were published by Taylor et al. ${ }^{89}$, who demonstrated increased interstitial cell proliferation early after infarct induction in the rat heart. The phenotype of the participating interstitial cell types, predominantly fibroblasts and endothelial cells ${ }^{13}$, has not been identified in these study.

\section{- Vascular component}

As mentioned above, the cardiac interstitial cells are partly represented by endothelial cells, which will be discussed separately as 'vascular component'.

Cardiac vessel growth is very low in normal adult hearts and is induced only under certain circumstances ${ }^{90}$. In the non-infarcted myocardium an increase of the total capillary density and capillary to myocyte ratio has been reported 30 days after coronary artery occlusion in the rat ${ }^{55}$. In the majority of studies, a deficit in the microvascular network was shown after infarct induction. Early investigations by Roberts and Wearn ${ }^{91}$ found that the capillarity is decreased in myocardial hypertrophy. The authors suggested that capillaries do not proliferate, which results in an increase in intercapillary distances due to a rise in cardiomyocyte diameter. Similar findings have been obtained in many subsequent experimental studies, in which the capillary supply to the surviving hypertrophic cells was decreased in the early and late phases after infarction ${ }^{54,57,63.92-96}$, as expressed in morphometric parameters like capillary density, capillary luminal volume, capillary surface density and elevated diffusion distances. From ultrastructural studies Anversa and co-workers ${ }^{54,94}$ concluded that the capillary density in the hypertrophied non-infarcted part decreased by up to $22 \%$, such that diffusion distances for oxygen were increased by $16 \%$. The capillary density decreased more as the infarct size increased ${ }^{96}$.

The response of the coronary vasculature within the surviving myocardium could be a mechanism generating a relative energy starvation that, in turn, may lead to local ischemia and tissue damage ${ }^{11.96}$ and may account, at least in part, for the impaired performance of infareted hearts ${ }^{96}$ 
Regional differences in vascular adaptation in the surviving myocardium seem to exist after myocardial infarction and several studies have focused on changes of the microvasculature in the peri-infarct region of the left ventricle, also called border zone. The number of myocytes and capillaries across the wall in the noninfarcted region was found to be decreased at the completion of healing of large infarcts ${ }^{97}$. A subnormal vascularization in regions close to the infarction has been reported shortly and several weeks after infarct induction in diverse morphometric studies ${ }^{55,92,98,99}$. On the other hand, results from flow experiments in isolated Langendorff-perfused rat hearts in combination with histological data, indicated substantial vessel growth with normalization of the coronary flow in the same zone within a few weeks after infarct induction ${ }^{100}$

The occurrence of vessel growth has been studied in other experimental models of ischemic heart disease. For example, gradually developing constriction of the epicardial coronary artery has been shown to induce proliferation of vascular endothelial cells in porcine and canine hearts ${ }^{111-1+4}$. Also, in a model of narrowing of the coronary artery in the rat. addition of newly formed capillaries has been observed in the (only examined) right ventriclei? Similar responses of the microvasculature have been obtained after coronary microembolization in the porcine heart ${ }^{104}$

\section{The renin angiotensin system}

Acute loss of cardiac function is associated with activation of neurohormonal systems, primarily the renin-angiotensin system (RAS) and the sympathetic nervous system (SNS), in an effort to enhance the contractile force of the ventricle $^{105}$. Other activated vasoconstrictors include vasopressin and endothelin. The actions of the endogenous vasoconstrictor factors are counterbalanced by the release of endogenous vasodilators such as atrial natriuretic peptide and endothelium-derived relaxing factor ${ }^{105}$.

The RAS was initially thought to be an endocrine system only regulating vascular tone and salt and water balance ${ }^{106}$. The peptide hormone angiotensin II (AngII) is the key mediator. Angll is known to play a role in cardiovascular homeostasis and exerts multiple biological effects, including systemic vasoconstriction, stimulation of the adrenal glands to release aldosterone (with resulting sodium retention and kaliuresis) and catecholamines, as well as pituitary mediated vasopressin 
secretion $^{106}$. Other physiological actions of AngII include direct positive inotropic and chronotropic effects ${ }^{107}$ on the myocardium, and effects on cardiovascular growth (see paragraph 3.5). These effects result in changes in preload and afterload in cardiac function. The endocrine system is activated under conditions of reduced blood pressure, sympathetic stress, or diminished circulating volume and is inactivated when these conditions are normalized ${ }^{106}$. Many observations have yielded evidence for the existence of mutual interactions between the RAS and the SNS at several levels. At the central nervous system level, AngII has been shown to have a facilitating effect on sympathetic outflow ${ }^{108}$ In the periphery, AngII can activate the release of noradrenaline from sympathetic fibers via stimulation of facilitating pre-synaptic AngII receptors and can inhibit the reuptake of noradrenaline ${ }^{108.109}$. Furthermore, AngII may act on the sympathetic ganglia and adrenal medulla to increase the release of catecholamines ${ }^{108}$.

AngII is formed in a cascade of enzymatic reactions. Angiotensinogen is synthesized and released by the liver. The first 10 amino acids of angiotensinogen represent angiotensin I, which is released by the action of renin. Renin is produced by the juxtaglomerular apparatus in the distal tubule in the kidney. Circulating angiotensin $\mathrm{I}$ is exposed to angiotensin converting enzyme (ACE), a primarily membrane-bound protein localized to the endothelial cells lining the vasculature. ACE catalyzes the conversion from angiotensin I into the octapeptide AngII Ior.

AngIl is degraded into several metabolites, such as AngIII and AngIV. AngI and AngII can be converted into Ang (1-7). Functions of AngIII and Ang (1-7) include stimulation of the release of aldosterone and vasopressin, as well as formation of prostaglandins ${ }^{110,111}$. Ang $(1-7)$ can exert vasodepressor and antiproliferative actions $^{111-114}$.

Several ACE substrates other than Angl are known. For example, ACE acts as a bradykinin-degrading enzyme and accordingly, activity of ACE simultaneously results in AngII formation and decreased levels of bradykinin ${ }^{115}$. Bradykinin stimulates prostacyclin formation as well as the release of endothelium-derived relaxing factor (EDRF) or nitric oxide ${ }^{116}$.

$\mathrm{ACE}$ is just one of the enzymes leading to fonmation of AngII. For example, the serine protease (chymase) pathway is likely to play an important role in cardiac Angll formation ${ }^{\text {117-119. }}$.

In recent years, other, at least partially indepent, local renin-angiotensin systems in a variety of tissues including the heart, have received considerable attention ${ }^{120}$. 
Conversion of AngI to AngII in isolated perfused hearts suggests the existence of an endogenous RAS $^{121}$. Further evidence demonstrating the presence of an endogenous RAS in the heart includes the myocardial expression of messengerRNA (mRNA) and protein products of angiotensinogen, renin, ACE, as well as Angll receptors ${ }^{107,122-127}$.

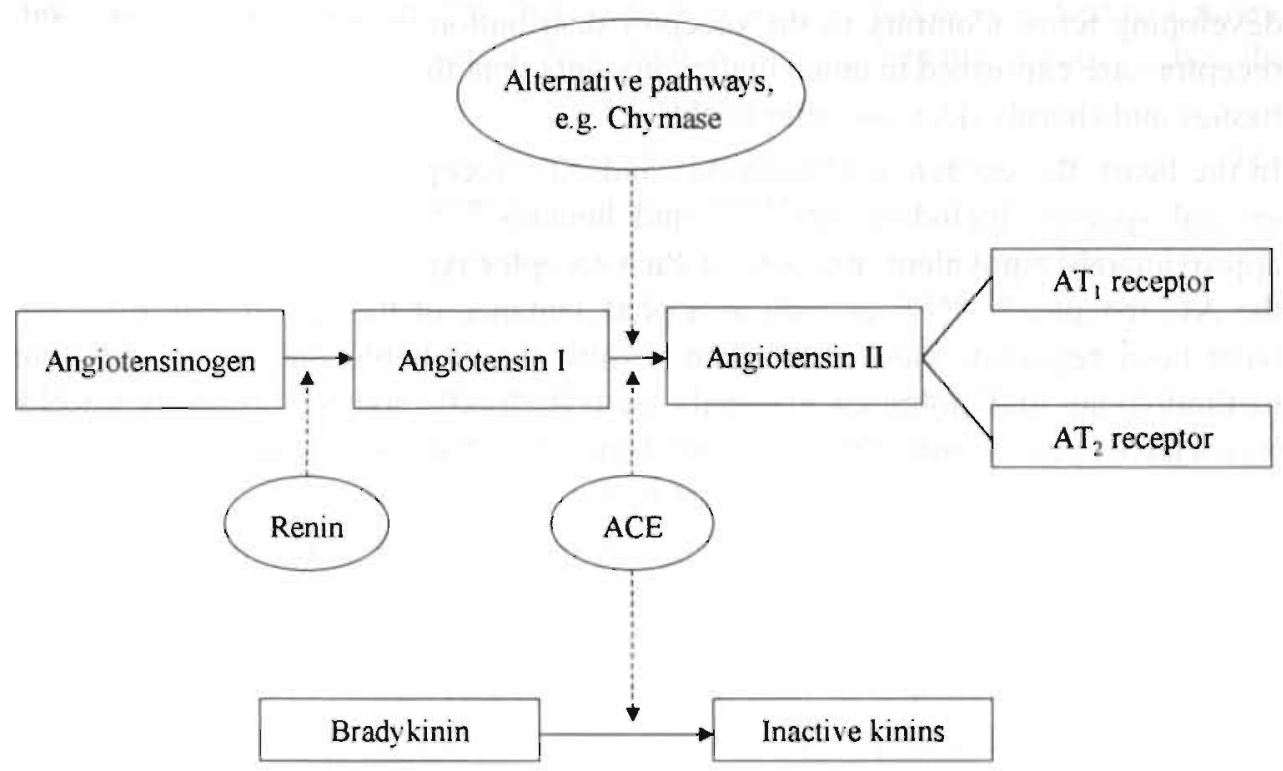

Figure 2: Cascade of the renin-angiotensin system

AngI and AngII have been detected in neonatal rat fibroblasts and ventricular myocytes ${ }^{128.129}$. The ability of cultured myofibroblasts to generate AngI and AngII de novo, has recently been demonstrated ${ }^{130}$. Also, microvascular endothelial cells isolated from adult rat ventricular muscle synthesized and secreted AngII in vitro $^{13 !}$.

\subsection{Angiotensin receptors}

The actions of AngII depend upon the presence of relevant angiotensin receptors. AngII receptors consist of at least two major subtypes ${ }^{1: 2}$ and have been characterized by using potent, highly selective subtype-specific AngII receptor antagonists. For example, the prototypical antagonist of $\mathrm{AT}_{1}$ receptors is losartan (Dup753), whereas PD123139, PD123177, or CGP42112A selectively bind $\mathrm{AT}_{2}{ }^{-}$ 
receptors $^{132,133}$. In rodents, two subvariants of the $\mathrm{AT}_{1}$ receptor have been identified as $\mathrm{AT}_{1 \mathrm{a}}$ and $\mathrm{AT}_{\mathrm{bb}}$ receptors, which have a $95 \%$ homology in amino acid sequence $^{134}$.

The density of $\mathrm{AT}_{1}$ and $\mathrm{AT}_{2}$ receptors in tissues was shown to be developmentally regulated and both $\mathrm{AT}_{1}$ and $\mathrm{AT}_{2}$ receptors are expressed in many tissues of the developing fetus. Contrary to the receptor distribution in mature tissues, the $\mathrm{AT}_{2}$ receptors are expressed in much higher amounts than the $\mathrm{AT}_{1}$ receptors in the fetal tissues and sharply decrease after birth ${ }^{135,136}$.

In the heart, the existence of both $\mathrm{AT}_{1}$ and $\mathrm{AT}_{2}$ receptors has been identified in several species, including rats ${ }^{137-139}$ and humans ${ }^{1+0.141}$. In nornal hearts either approximately equivalent amounts of each receptor type ${ }^{137.142}$, a predominance of the $\mathrm{AT}_{1}$ receptor ${ }^{138.143,144}$, as well as a predominance of the $\mathrm{AT}_{2}$ receptor ${ }^{139,140,145}$ have been reported; these discordant results are probably due to the different methodologies and biological materials used. Both $\mathrm{AT}_{\mathrm{Ia}}$ and $\mathrm{AT}_{\mathrm{Ih}}$ receptor mRNA levels have been identified in the normal heart ${ }^{127.146}$. Neonatal hearts demonstrate a greater abundance of AngIl receptors than the adult heart tissue $e^{137,1+2}$.

Activation of the AT, receptor lead to the majority of known functions of the RAS, like vasoconstriction, renal salt and water retention, the drinking response, inotropy, chronotropy, activation of arachidonic acid synthesis, and cell growth ${ }^{132,44}$. The function of the $\mathrm{AT}_{2}$ receptor is less clear, but it has a possible role in growth and development, differentiation and blood pressure regulation ${ }^{148}$.

Angll binding sites have been described that seem to be different from the known $\mathrm{AT}_{1}$ and $\mathrm{AT}_{2}$ receptors. For example, in the chick embryo chorioallantoic membrane and in the fowl AngIl receptors differ from $\mathrm{AT}_{1}$ and $\mathrm{AT}_{2}$ receptors in binding CGP42112A, but not the subtype specific antagonists PD123177 or losartan (DuP753) ${ }^{49.149}$. Also, human cardiac fibroblasts isolated from end-stage failing hearts were shown to express an atypical AngII receptor. This receptor was stimulated by AnglI, which was not prevented by co-incubation with losartan or $\operatorname{PD} 123317^{150}$.

\subsection{Signal-transduction pathways of AngII receptors}

$\mathrm{AT}_{1}$ and $\mathrm{AT}_{2}$ receptors show a low degree of structural homology $(34 \%)^{151}$ and each receptor subtype couples with its effector molecules via different intracellular pathways. The $\mathrm{AT}_{1}$ receptor is a member of the 7-transmembrane domain $\mathrm{G}$ protein coupled receptor superfamily ${ }^{152}$. The coupling of AngII to the $A T_{1}$ 
receptor involves a number of signaling pathways, including phospholipase $C$, phospholipase A2, phospholipase $\mathrm{D}$, adenylate cyclase and ion channels ${ }^{152}$.

Activation of phospholipase $\mathrm{C}$ results in hydrolysis of phosphatidyl-inositol biphosphate (PIP2) to diacylglycerol (DAG) and inositol-triphosphate (IP3) ${ }^{132}$ leading to the activation of protein kinase $\mathrm{C}$ (PKC) and the mobilization of intracellular $\mathrm{Ca}^{2+}{ }^{232,153}$. Furthermore, the $\mathrm{AT}_{\mathrm{I}}$ receptor has been linked to kinases, like mitogen-activated protein (MAP)-kinases ${ }^{154,155}$, tyrosine kinases, and the Jak/STAT-pathway ${ }^{156-158}$.

Phospholipase $A 2$ and $D$ are responsible for arachidonic acid formation ${ }^{152}$. The $\mathrm{AT}_{1}$ receptor can act on adenylate cyclase, regulating the level of $\mathrm{CAMP}^{152.159 .160}$.

The signaling pathways of the $\mathrm{AT}_{2}$ receptor have been less elucidated. The $\mathrm{AT}_{2}$ receptor selectively couples to $\mathrm{Gi}-\alpha$ in the rat fetus ${ }^{161}$. Some studies have shown that the $\mathrm{AT}_{2}$ receptor mediates levels of cyclic guanosine 3'5'-monophosphate (cGMP) in the rat kidney and in $\mathrm{PCl} 2 \mathrm{~W}$ cells ${ }^{162.163}$. Activation of $\mathrm{AT}_{2}$ receptors have elicited an inhibition of MAP-kinases by activation of specific phosphotyrosine phosphatases ${ }^{164.165}$. Other studies have slown that the $\mathrm{AT}_{2}$ receptor either stimulates ${ }^{163,166,167}$, not affects ${ }^{151}$ or inhibits tyrosine phosphatase activity $^{168}$.

\subsection{Expression of AngII receptors in different cardiac cell types}

A limited amount of studies determining the distribution of AngII receptors on various cardiac cell subtypes (i.e. myocytes, fibroblasts, endothelial cells and cells of the conductive system) has been underlaken

Radioligand binding studies have shown the presence of both $A T_{1}$ and $A T_{2}$ receptors in embryonic and neonatal rat ventricular cardiomyocytes ${ }^{169.170}$. The presence of $A T$, receptor $m R N A$ has been demonstrated in human ${ }^{144}$ and in rat cardiomyocytes ${ }^{170}$, and rat cardiomyocytes were shown to express both $\mathrm{AT}_{\mathrm{la}}$ and $\mathrm{AT}_{16}$ receptor $\mathrm{RRNA}^{170}$. In contrast to $\mathrm{AT}_{1}$ receptors, the amount of $\mathrm{AT}_{2}$ receptors decreases directly after birth and has almost disappeared from adult ventricular myocytes ${ }^{170.17 !}$.

In cardiac fibroblasts, the presence of $\mathrm{AT}_{1}$ receptor expression has been reported in cultured embryonic ${ }^{170}$, neonatal ${ }^{170.172 .173}$ and adult rat cells ${ }^{173-175}$. The fibroblast $\mathrm{AT}_{1}$ receptors were reported to be mainly of the $\mathrm{AT}_{1 \mathrm{a}}{ }^{-r e c e p t o r}$ subtype ${ }^{170}$. In human (adult) and rat (neonatal and adult) hearts the presence of $\mathrm{AT}_{\mathrm{I}}$ mRNA in non-myocytes has been demonstrated ${ }^{144,173}$. Myofibroblasts have been shown to 
express $\mathrm{AT}_{1}$ receptors ${ }^{176}$. Binding studies with cultured rat fetal cardiac fibroblasts showed the presence of $\mathrm{AT}_{2}$ receptors on these cells, and the expression of $\mathrm{AT}_{2}$ receptors decreased dramatically after birth ${ }^{170}$. Both receptor subtypes were also present in cultured fetal rat skin fibroblasts ${ }^{159}$. In the rat subcutaneous sponge granuloma model both $\mathrm{AT}_{1}$ and $\mathrm{AT}_{2}$ receptors were localized to non-vascular stromal cells ${ }^{177}$.

In the vasculature of the one-day-old neonatal heart AngII receptors, predominantly $\mathrm{AT}_{2}$ receptors, were highly concentrated, whereas they were barely detectable in the myocardium using quantitative autoradiographic techniques ${ }^{178}$. Positive immunoreactivity for the $\mathrm{AT}_{2}$ receptor was localized in the endothelium of the coronary vessels of young rats ${ }^{17 !}$. The presence of both $\mathrm{AT}_{1}$ and $\mathrm{AT}_{2}$ receptors in cultured cardiac endothelial cells derived from adult spontaneously hypertensive rats (SHR and Wistar Kyoto rats has been reported ${ }^{180}$. Also in the human heart, $\mathrm{AT}_{1}$-receptor $\mathrm{mRNA}$ has been localized on vessel walls ${ }^{144}$. In the rat subcutaneous sponge granuloma model $\mathrm{AT}_{1}$ receptors were partly localized to microvessels ${ }^{177}$.

In cells of the autonomic nervous system, especially the cardiac conductive tissue and nerve terminals, AngII receptors have also been detected ${ }^{137,178.181}$, with the $\mathrm{Al}_{2}{ }_{2}$ receptor as the major subtype in the neonatal conducting system. In the adult conducting system the total expression of AngII receptors was greatly reduced, with predominance of $\mathrm{AT}_{1}$ receptors ${ }^{178}$.

In summary, studies indicate that all major cell types of the normal heart are able to express $\mathrm{AT}_{1}$ - as well as $\mathrm{AT}_{2}$ receptors; the $\mathrm{AT}_{2}$ receptor is expressed mainly in the fetal and neonatal period, whereas $A T_{1}$ receptors are expressed throughout maturation and adulthood.

\subsection{Expression of the RAS in cardiac remodeling}

In the animal infarct model an upregulation of the AngII receptors in the noninfarcted viable myocardial tissue has been reported, early (from only a few days after infarction) ${ }^{171.182}$, as well as later in the post-infarction course ${ }^{59}$.

In the non-infarcted viable portion an increase in $\mathrm{AT}_{1}$ receptor number and $\mathrm{AT}_{1}$ receptor $\mathrm{mRNA}_{1}$ (especially the $\mathrm{AT}_{1 \mathrm{a}}$ receptor) have been reported $\mathrm{d}^{59,127.171}$, as well as an upregulation of $\mathrm{AT}_{2}$ receptors and $\mathrm{AT}_{2}$ receptor mRNA in whole ventricular 
tissue $^{127}$. In contrast, isolated purified ventricular myocytes were found to exclusively possess the $\mathrm{AT}_{1}$ receptor ${ }^{171}$.

Other conditions associated with myocardial hypertrophy showed a diversity of changes in AngII receptor density. The cardiac hypertrophy induced in rats with two-kidney one-clip renovascular hypertension and in spontaneously hypertensive rats (SHR), is associated with increased cardiac $A T_{1 a}$ receptor $m R N A$, and $A T_{1}$ and $\mathrm{AT}_{2}$ receptor binding sites ${ }^{142}$. Also, an increase of the $\mathrm{AT}_{2}$ receptor has been reported in the hypertrophied left ventricle following partial aortic banding ${ }^{143}$ and after induction of an $\mathrm{AV}$-shunt ${ }^{183,184}$. The $\mathrm{AT}_{2}$ receptor is re-expressed by cardiac fibroblasts from failing myopathic hamsters ${ }^{175}$. An in vitro stretch model using 1 day old rat myocytes showed an upregulation of both $\mathrm{AT}_{1}$ and $\mathrm{AT}_{2}$ receptors ${ }^{185}$. Also, a decrease or no change in AT, receptors in several conditions of cardiac hypertrophy have been reported, for instance in hearts of rats subjected in models of pressure overload ${ }^{143,146}$.

In humans, there is conflicting information on the status of cardiac AngII receptor density in chronic heart failure, with one study ${ }^{186}$ describing no change in total AngII receptor density, and others reporting a decrease in the level of expression of the angiotensin $\mathrm{AT}_{1}$, but not of the $\mathrm{AT}_{2}$ receptors in ventricular tissue ${ }^{144,187}$. These findings differ from the results from human atrial myocardium, in which the level of $\mathrm{AT}_{2}$ receptors was decreased ${ }^{140}$ or was upregulated ${ }^{141}$ in heart failure.

Besides increased levels of AngII receptors, also increased levels of angiotensinogen ${ }^{188}$, renin ${ }^{123}$, and $A C E^{122.189 .190}$ have been described in infarcted rat hearts. The enluanced expression of renin and ACE was localized to the border zone of the infarcted left ventricle ${ }^{122,123}$. ACE and AngII receptor (predominantly the $A T_{1}$ receptor) binding density was enhanced from the first week after infarction ${ }^{191.192}$. Cells expressing ACE at the infarct site include macrophages, endothelial cells, and myofibroblasts ${ }^{43,192}$.

\subsection{The RAS as a regulator of cardiac remodeling}

The RAS not only has a key role in normal cardiovascular function, but also in the regulation of cardiac remodeling and this regulation involves both the myocyte and the non-myocyte compartment. 
Evidence for a direct role for AngIII-mediated myocardial collagen metabolism exists, since in vitro, AngII enhances collagen by a dual effect on cultured cardiac fibroblasts. First, AngII induces enhanced expression of mRNA of collagen type I, collagen type III and fibronectin in cardiac fibroblasts ${ }^{173,232}$. Second, AngII reduces collagenolytic activity through inhibition of collagenase activity in these cells ${ }^{232}$.

In vitro studies have yielded conflicting results regarding the mediating role of the $\mathrm{AT}_{1}$ and $\mathrm{AT}_{2}$ receptors in collagen metabolism. Both $\mathrm{AT}_{1}$ and $\mathrm{AT}_{2}$ receptors have been reported to stimulate collagen synthesis in fibroblasts isolated from normal adult rat hearts ${ }^{232}$, and, in addition, the $\mathrm{AT}_{2}$ receptor appeared to decrease collagenase activity ${ }^{232}$. In contrast, in cardiac fibroblasts isolated from cardiomyopathic hamsters the $\mathrm{AT}_{2}$ receptor has been reported to inhibit synthesis of extracellular matrix components ${ }^{175}$.

Mechanical stretching of cardiac fibroblasts in culture was capable to increase the amount collagen type III protein and $\mathrm{mRNA}^{233}$, indicating that increased pressure and/or mechanical tension in the heart may be mediators for upregulation of collagen gene expression. However, results from many different in vivo studies argue against a primary role of blood pressure in the regulation of collagen accumulation $^{207,224,225,229}$.

Toxic effects of AngII on cardiomyocytes resulting in myocyte necrosis and repair fibrosis might be considered another mechanism responsible for raising myocardial collagen concentration ${ }^{219,225,234}$.

The contribution of bradykinin to the RAS in mediating cardiac fibrosis has been subject to several studies. Co-administration of AngII with the bradykinin B2 receptor antagonist HOE140 completely prevented AngII induced cardiac perivascular and interstitial collagen accumulation ${ }^{220}$. Following infarction kinins appeared to contribute to the effects of ACE inhibition on myocardial collagen, since B2 kinin receptor blockade (partially) reversed the effect of ACE inhibition on left ventricular interstitial collagen ${ }^{57.196}$. Other candidates mediating effects of the RAS on collagen include aldosterone ${ }^{45,221.232}$ and prostaglandins 220 .

Finally, an indirect effect of AngIl through interaction with the sympathetic nervous system may be another mechanism $225,229,234$.

Far less is known about the involvement of the RAS in remodeling of the interstitial cellular compartment of the myocardium, i.e. the non-myocytes consisting mainly of fibroblasts and endothelial cells, as described previously. In most in vivo studies, just 'non-myocytes' (interstitial cells) have been investigated without determining the particular cell type involved. 
AngII infusion in rats increased myocardial $\left[{ }^{3} \mathrm{H}\right]$ thymidine labeling, predominantly nuclei of interstitial cells $\mathrm{s}^{219,223}$. Early ACE inhibition with captopril completely prevented infarction-induced DNA synthesis in interstitial cells in the noninfarcted left ventricle two weeks after infarction in the rat ${ }^{68}$. In the same model, administration of the $\mathrm{AT}_{1}$ antagonist losartan only slightly reduced the increased interstitial cell DNA synthesis ${ }^{198}$. Similar results have been obtained by Taylor et al., who showed that post-infarction enhanced non-myocyte PCNA expression was abolished by the ACE inhibitor enalapril, and not by $\operatorname{losartan}^{89}$. These findings suggest effects on interstitial cell proliferation mediated by non $\mathrm{AT}_{1}$ receptor mechanisms after infarction.

In vitro, AngII induced an increase in DNA synthesis and/or cell number in neonatal $^{172,204}$ and adult non-myocyte (probably mostly fibroblasts) cultures ${ }^{235}$. This response appeared to be mediated by the $\mathrm{AT}$, receptor, and not by $\mathrm{AT}_{2}$ receptors ${ }^{172.204 .235}$. In human cultured cardiac fibroblasts DNA synthesis was stimulated by AngII through an atypical receptor ${ }^{(50)}$.

Inhibition of DNA synthesis was shown to be mediated by the $\mathrm{AT}_{2}$ receptor in cardiac fibroblasts isolated from cardiomyopathic liamsters ${ }^{175}$.

\section{- Vascular compartment}

The endothelial cell, the other major cell-type of the interstitium, may also be part of the proliferative response after infarction. A link between angiogenesis and the RAS has been known for some time but divergent results have emerged on the exact role of the RAS in vascular formation.

AngII has been reported to induce angiogenesis in the avascular rabbit cornea, in the rat cremaster muscle 236.237 , in the rat subcutaneous sponge granuloma model $^{177.238}$ as well as in the chick chorioallantoic membrane ${ }^{49.239}$. In addition, AngII stimulated proliferation of cultured rat glomerular endothelial cells $\mathrm{s}^{240}$.

However, ACE inhibition, which decreases AngII formation, has been reported to increase cardiac vascularity in several experimental models. In infarcted rats the cardiac capillary density was significantly increased by long tern ACE inhibition ${ }^{57}$. Also in young and adult spontaneously hypertensive rats (SHR), longterm ACE inhibition with captopril or ramipril increased cardiac capillarization with or without concurrent reduction of left ventricular mass $\mathrm{s}^{241-24,3}$.

On the other hand, other studies have shown a decrease in number of microvascular vessels after treatment with ACE inhibitors. ACE-inhibition with captopril or zabiciprilate abolished the increase in the capillary-to-fiber ratio in the soleus muscle during ischemia ${ }^{2+4}$. In addition, after 4 weeks' treatment with captopril, the density of small arteriolar vessels in cremaster muscles was reduced 
in renal hypertensive and normotensive rats ${ }^{245}$. Volpert et al. ${ }^{246}$ also demonstrated an anti-angiogenic activity of the ACE inhibitor captopril in the rat cornea.

Several studies explored the function of the AngII receptor subtypes in vascular formation. A mediating role of the $\mathrm{AT}_{1}$-receptor in AngII induced angiogenesis has been reported in the rat subcutaneous sponge granuloma model ${ }^{177,238}$ and in the rat cremaster muscle ${ }^{237}$. In cultured glomerular endothelial cells of the rat, AngII induced mitogenesis was inhibited by $\mathrm{AT}_{1}$-receptor blockade with losartan ${ }^{240}$. In cultured coronary endothelial cells, AngII only stimulated proliferation after pretreatment with the $\mathrm{AT}_{2}$ antagonist $\mathrm{PD} 123177$, an effect that was reversed by additional pretreatment of the $\mathrm{AT}_{1}$ receptor antagonist losartan, while the $\mathrm{AT}_{2}$ specific agent CGP42112A mimicked the antiproliferative actions of AngII ${ }^{180}$. $\mathrm{AT}_{2}$ receptor blockade with PD123319 enhanced the AngII stimulated increase of vascular density in the rat cremaster muscle ${ }^{237}$. These observations suggest a mediating role for the $\mathrm{AT}_{1}$ receptor in stimulating vascular growth and antiproliferative effects mediated through $\mathrm{AT}_{2}$ receptors.

On the other hand, in the setting of myocardial infarction a significant increase in cardiac microvascular density in the non-infarcted region through $A T_{1}$-antagonism has repeatedly been observed ${ }^{57,98}$. Long-term treatment with the $\mathrm{AT}_{2}$ antagonist PD123319 started 2 months after infarction did not alter cardiac capillarity in the rat heart, and did not significantly influence the effects of $\mathrm{AT}_{1}$ receptor antagonism $^{57}$.

Several explanations how $\mathrm{AT}_{1}$-receptor blockade can increase capillary vascularization after infarction can be considered, besides effects directly mediated through $\mathrm{AT}_{1}$ receptors. Increased capillary density could simply reflect reduced post-infarction myocyte hypertrophy after $\mathrm{AT}_{\text {, receptor treatment }}{ }^{57,98}$, but this seems unlikely, since a decrease in myocyte-to-capillary ratio has also been determined in one of these experiments ${ }^{98}$. Altenatively, increased stimulation of $\mathrm{AT}_{2}$ receptors during $\mathrm{AT}$, receptor blockade could account for the observed increased capillary density induced by long-term $\mathrm{AT}_{1}$-antagonist treatment after infarction. Both renin secretion and AngII levels in plasma and the heart increase during blockade of $\mathrm{AT}_{1}$ receptors ${ }^{247}$ and consequently increased AngII levels may stimulate the $\mathrm{AT}_{2}$ receptor.

Taken together, the RAS is likely to play an important, though not fully clarified, role in the regulation of angiogenesis after myocardial infarction. 


\subsection{Effects of RAS interventions in clinical trials}

Early reports of experimental myocardial infarction have shown that ACEinhibition increases cardiac function ${ }^{248}$ and survival ${ }^{12,249}$. A large number of randomized clinical trials have demonstrated the efficacy of several ACE inhibitors in terms of morbidity and mortality in patients with myocardial infarction. Late-entry trials (treatment started after $>3$ days following infarction) have shown an overall survival benefit of $\sim 20 \%{ }^{28,250}$. Most, but not all studies ${ }^{251}$, showed a significant survival benefit with early ACE-inhibitor treatment (started within 24 hours following infarction) ${ }^{252-255}$. The early use of ramipril after infarction attenuated left ventricular dilatation and was associated with a prompter recovery of left ventricular ejection fraction ${ }^{256}$.

Results from a recent clinical trial comparing losartan versus captopril in heart failure patients suggest that $\mathrm{AT}_{1}$ receptor blockade may be superior over $\mathrm{ACE}$ inhibition ${ }^{257}$.

\section{The sympathetic nervous system}

The sympathetic nervous system (SNS) is another important regulator of the structure and function of the cardiovascular system in health and disease. Catecholamines, like noradrenaline released by excitation of sympathetic nerves and adrenaline (the primary adrenal medullary hormone and also a neurotransmitter) are involved in regulating functions that integrate central and peripheral responses to a range of stresses ${ }^{258}$. Central sympathetic outflow is regulated in the brain stem and the medulla oblongata ${ }^{259}$. Both noradrenaline and adrenaline play important roles in the control of vascular tone, myocardial contractile rate and force, airway reactivity, and a variety of metabolic functions ${ }^{258}$.

The SNS is known to be a regulator of renin release in the kidney ${ }^{261}$ Alphaladrenergic receptors have been described to be involved in the Angll-induced increase of vascular smooth muscle cell DNA synthesis in the rat ${ }^{262,263}$.

\subsection{Adrenoceptors}

Adrenoceptors form the interface between the SNS and the cardiovascular system and constitute a large superfamily of receptors, linked to seven-transmembrane guanine-nucleotide-binding proteins $(G \text { proteins })^{264}$. Adrenoceptors are found in 
nearly all peripheral tissues and within the brain ${ }^{260}$. As from before 1948 two general classes of adrenoceptors have been termed $\alpha$ - and $\beta$-adrenoceptors ${ }^{265}$. Alpha-adrenoceptors have been further subdivided into two classes, $\alpha 1$ - and $\alpha 2$ adrenoceptors $^{266,267}$. Alphal-adrenoceptors traditionally have been described to be located on postsynaptic sites mediating the response of the effector organ ${ }^{266}$, but there is also evidence for the existence of pre-junctional inhibitory $\alpha 1$ adrenoceptors $^{266}$. Rats have a relatively high number of cardiac $\alpha 1$-adrenoceptors compared to humans and other mammals ${ }^{268.269}$.

Alphal-adrenergic subtypes are, on the basis of pharmacological and molecular cloning studies further subdivided into $\alpha 1 \mathrm{~A}, \alpha 1 \mathrm{~B}$ and $\alpha 1 \mathrm{D}^{260.270}$ and the existence of additional subtypes is being investigated ${ }^{271}$.

Alpha2-adrenoceptors are located pre-synaptically on nerve terminals and reduce neurotransmitter release from these nerve endings and at postsynaptic sites ${ }^{266,272}$. The pre-synaptic $\alpha 2$-adrenoceptor serves as an important element in a local feedback system modulating neurotransmitter release ${ }^{266}$. At least three subtypes of $\alpha 2$-adrenoceptors have been identified: $\alpha 2 \mathrm{~A}$-, $\alpha 2 \mathrm{~B}$-, and $\alpha 2 \mathrm{C}$-adrenoceptors ${ }^{273}$.

Beta-adrenoceptors have been well characterized and have been subdivided into at least three subtypes, $\beta 1-, \beta 2-$, and $\beta 3$-adrenoceptors (for review see Hieble, $1995)^{267}$.

\subsection{Signal-transduction pathways of adrenergic receptors}

Alphal-adrenoceptors are coupled to a diversity of signaling intracellular pathways. These include the phospho-inositide pathway via a specific phospholipase $C$ (PLC) to produce two intracellular messengers, inositol 1,4,5triphosphate $\left(\mathrm{IP}_{3}\right)$ and diacylglycerol $(\mathrm{DAG})^{27.4} \cdot \mathrm{IP}_{3}$ can release intracellular $\mathrm{Ca}^{2+}$ and DAG activates protein kinase $C$, with resultant phosphorylation of multiple cellular substrates including $\mathrm{Ca}^{2}$ channels ${ }^{271.275}$. In addition to the phosphoinositide metabolism, $\alpha$ l-adrenergic stimulation is also able to affect, at least under certain circumstances, cyclic AMP (cAMP) levels, some phospholipases, ion channels and arachidonic acid metabolism ${ }^{274.276}$. An active area of research is the involvement of second messengers of $\alpha 1$-adrenoceptors in growth and hypertrophy ${ }^{271}$. Among others, the proto-oncogene ras, Raf-l, and mitogenactivated protein (MAP) kinases have been implicated in these processes ${ }^{271.277}$ Alpha2-adrenoceptors have classically been classified as inhibitors of adenylyl cyclase $^{266,278}$, but alternative signaling transduction pathways have also been observed, such as modulation of several phospholipases, the level of intracellular $\mathrm{Ca}^{2+}$, ion channels ${ }^{266.276}$ and a mitogen-activated protein (MAP) kinase cascade ${ }^{278}$. 
Elevation of intracellular $\mathrm{Ca}^{2+}$ and the second messenger cAMP are the most important intracellular signaling pathways in the $\beta$-adrenergic system. Activation of $\beta 1$ - or $\beta 2$-receptor subtypes leads to formation of CAMP via adenylate cyclase $^{273}$. Subsequently this induces the activation of cAMP-dependent protein kinase $A^{277,279}$, which targets and phosphorylates several myocardial proteins, including the MAP kinases ${ }^{277}$. Adrenergic receptor signaling is complex, due, in part, to the ability of a given subtype to couple to several different G-proteins or effector systems ${ }^{267.271}$.

\subsection{Expression of adrenoceptors in different cardiac cell types}

Adrenoceptors are found in a variety of organs and tissues, but description here will be limited to those found in the heart. Cardiac adrenoceptors are located on several different cell types.

On rat myocytes $\beta 1-, \beta 2$ - and $\beta 3$-adrenoceptors are present ${ }^{276,282,283}$, with predominance of the $\beta 1$-receptor ${ }^{282.283}$. Also, $\alpha 1$-adrenoceptors (at least three $\alpha 1$ adrenergic subtypes) have been identified on the surface of cardiomyocytes $^{271,284,285}$.

Myocardial non-inyocytes have been reported to contain $\beta$-adrenoceptors (predominantly $\beta 2,3$-adrenergic) ${ }^{286,287}$. Alphal-adrenoceptors also were described to exist on the cell surface of non-myocytes, without further specification of cell type ${ }^{287}$, whereas no, or a less amount of $\alpha 1$ - adrenoceptors have been detected on these cells by others ${ }^{28+, 285}$.

Coronary vessels have been reported to contain $\alpha 1^{276.284}$ and $\alpha 2$-adrenoceptors $^{276,238}$, as well as $\beta 1$ - and $\beta 2$-adrenoceptors ${ }^{276}$. Alphal-adrenoceptors have also been identified in endothelial cells of the cardiac microvasculature ${ }^{284}$.

Nerve terminals possess $\alpha 2$ - and $\beta 2$-adrenoceptors ${ }^{266.275}$, as well as $\alpha 1$ adrenoceptors $^{284}$.

\subsection{The SNS as a regulator of cardiac remodeling}

Besides mechanical forces and other effectors such as the RAS, the SNS is a likely candidate to play an important role the regulation of cardiac remodeling. 


\section{- Cardiomyocytes}

By far the most attention has been paid to the contribution of the SNS to cardiomyocyte hypertrophy. An early study on the morphological effects of adrenergic stimulation on the rat heart muscle has been reported by Rona et al. ${ }^{289}$, in which high doses of the $\beta$-adrenergic agent isoproterenol induced extensive myocyte necrosis. Continuous infusion of noradrenaline in rats caused increases in absolute ventricular weight and in ventricular weight-to-body-weight-ratio, as well as ventricular expression of mRNAs for atrial natriuretic factor (ANF), skeletal $\alpha$ actin and $\beta$-myosin heavy chain ( $\beta-\mathrm{MHC}$ ), which in the adult rat ventricle generally are accepted as molecular indicators of hypertrophy ${ }^{290}$.

Both $\beta$ - and $\alpha$-adrenoceptors may modulate the development of cardiac hypertrophy. The fact that $\beta$-adrenergic stimulation produces cardiac enlargement in vivo is well established ${ }^{291-299}$, and the hypertrophic response is accompanied by the transient expression of nuclear proto-oncogenes like $c$-fos and jun- $\mathrm{B}^{299}$.

Some studies report on the effects of $\beta$-adrenergic modulation following myocardial infarction. Long-term $\beta$-adrenergic inhibition by propranolol starting 2 days after permanent left coronary artery occlusion to produce transmural infarction, reduced myocyte cross-sectional area and volume, and induced left ventricular dilatation. ${ }^{300}$, suggesting undesirable inhibition of an adaptive hypertrophic response. In rats subjected to short-time coronary occlusion and reperfusion to produce non-transmural infarction, a 3 week administration of propranolol starting 5 days after surgery, suppressed exercise-induced regional myocardial hypertrophy in the infarcted and reperfused region and caused global left ventricular dilatation ${ }^{30 !}$. Furthermore, in other models such as cardiac hypertrophy in response to coarctation of the aorta or right ventricular hypertrophy induced by hypoxia, hypertrophy was significantly attenuated by $\beta$-receptor blockade $^{302,303}$. However, long-term treatment with the $\beta 1$-antagonist metoprolol or a sympatholytic DA2/ $\alpha 2$ agonist (CHF-1024) started late (2 months) after infarct induction did not decrease cardiac hypertrophy nor influence left ventricular dilatation ${ }^{304}$.

Alpha-adrenoceptors may also mediate hypertrophy. In the isolated adult rat heart short-time perfusion with the $\alpha \mathrm{l}$-adrenergic agonist phenylephrine stimulated protein synthesis, an effect that was prevented by the $\alpha 1$-receptor antagonist prazosin $^{305}$. Transgenic mice over-expressing a constitutively active myocardial $\alpha$ lB-adrenergic receptor showed clear cardiac hypertrophy ${ }^{306}$. Seven days after infarct induction, noradrenaline-stimulated phospho-inositol turnover was increased threefold in isolated viable myocytes, suggesting that effector pathways 
linked to the $\alpha$ l-adrenergic receptor stimulate the myocyte hypertrophic response ${ }^{307}$. Following localized myocardial damage by electric DC-shock, $\alpha 1$ adrenergic receptor blockade inhibited the increase in mass during the first week, though it was ineffective by 16 weeks $^{210}$.

Evidence for a direct relationship between the adrenergic system and myocyte hypertrophy has been strengthened by many in vitro studies. The hypertrophic response to adrenergic receptor stimulation has been attributed to activation of the $\alpha 1-{ }^{277.308-310}$ and the $\beta$-adrenergic receptor ${ }^{277.310}$ in neonatal cardiomyocytes. A hypertrophic effect through both $\alpha 1$ - and $\beta$-adrenoceptors could also be demonstrated in adult cultured cardiomyocytes ${ }^{311-314}$ and the hypertrophic effect of $\beta$-adrenoceptor stimulation was shown to be due to stimulation of the $\beta 2$ adrenergic receptor subtype ${ }^{312}$.

Concomitant stimulation of $\beta$-adrenergic (by isoproterenol) and $\alpha 1$-adrenergic receptors (by phenylephrine) exerted a synergistic effect on increased protein synthesis in cultured cardiomyocytes ${ }^{277}$.

Besides quantitative changes, also qualitative alterations in myocytes have been determined, including induction of immediate early genes (like $c-m y c, c-f o s, c-j u n$ ) and selective upregulation of early developmental iso-genes (like $\beta$-myosin heavy chain ( $\beta-\mathrm{MHC}$ ) and skeletal $\alpha$-actin) ${ }^{275,277,315-317}$.

There are also studies that failed to show a mediating role of the SNS in cardiac hypertrophy. For example, epicardial denervation or $\alpha$ - / $\beta$-receptor blockade did not influence right ventricular hypertrophy after hemodynamic overloading by banding the pulmonary artery ${ }^{318}$. Concordant with these results, neither $\alpha$-nor $\beta$ adrenergic stimulating agents were able to induce cardiac growth in the absence of accompanying hemodynamic load in a model of a hemodynamically unloaded heterotopically transplanted heart ${ }^{319}$. These studies suggest that neither adrenergic activation is necessary for the cardiac hypertrophic response to hemodynamic overload, nor that adrenergic stimulation is able to cause hypertrophy independently from hemodynamic load. However, the hypertrophic effect induced by noradrenaline seemed to be independent of changes in the peripheral circulation in experimental animals ${ }^{291.292,320}$. In line with this observation, increased left ventricular mass in normotensive and in hypertensive patients was closely coupled to an increased cardiac sympathetic activity, whereas blood pressure did not correlate with left ventricular mass ${ }^{321}$. In an in vitro study comparing the effects of mechanical activity with $\alpha 1$-adrenergic effects, it was shown that $\alpha 1$ adrenergic stimulation with phenylepinephrine increased $\beta$-myosin heavy chains $(\beta-M H C)$ in neonatal myocytes, whereas mechanical activity per se did not alter 
the MHC pattern ${ }^{322}$. Isoproterenol induced muscle gene expression in high density cultured neonatal myocytes was shown to be independent of contractile activity ${ }^{317}$.

Furthermore, $\beta$-adrenoceptor mediated hypertrophy has been linked to the presence of myocardial necrosis in some studies ${ }^{293}$, but it did not appear to be merely a direct compensation for myocyte loss or necrosis in other studies ${ }^{297.319}$. The case for a direct effect of the sympathetic nervous system on cardiac growth is also clouded by the interaction of this system with several humoral factors such as the RAS. Indeed, some studies suggest participation of the RAS in $\beta$-adrenergic induced cardiac hypertrophy. Concomitant ACE-inhibition attenuated left ventricular hypertrophy induced by $\beta$-adrenergic stimulation ${ }^{323-325}$. This effect has also been described for co-administration of an $\mathrm{AT}_{1}$ receptor antagonist ${ }^{325}$, whereas other authors did not find a decreasing effect of $\mathrm{AT}_{1}$ receptor antagonism on the cardiac hypertrophic response to isoproterenol ${ }^{298}$.

\section{- Extracellular matrix and interstitial cells}

Administration of hypertensive doses of noradrenaline significantly increased myocardial hydroxyproline concentration (reflecting the amount of collagen) and mRNA concentration of collagen I in the rat witlin one week ${ }^{326.327}$.

Beta- as well as $\alpha$-adrenergic effects on collagen metabolism have been described. An increase of cardiac collagen content is a well-known effect of $\beta$-adrenergic stimulation in the adult rat with treatment duration varying from several days to 6 weeks $^{292.293 .297 .328 .329}$. Isoproterenol-induced myocardial fibrosis was initiated by the appearance of fibrillar collagen disruption, followed by the formation of collagen fibers encircling cardiomyocytes ${ }^{320}$. On the other hand, $\beta$-adrenergic inhibition by celiprolol during 3 weeks induced a further increase in cardiac collagen concentration in adult spontaneously hypertensive rats ${ }^{330}$.

In the infarcted rat, long-term treatment with the $\beta 1$-receptor antagonist metoprolol or the sympatholytic agent DA2/ 22 agonist (CHF-1024) started 2 months after surgery significantly reduced collagen content in the non-infarcted left ventricle ${ }^{304}$. Early studies showed that in young spontaneously hypertensive rats (SHR), short-term (3-6 weeks) treatment with the sympatholytic agent $\alpha$ methyldopa increased cardiac collagen concentration ${ }^{331}$, whereas long-tenn (21 weeks) therapy prevented the increase of collagen content ${ }^{322}$, suggesting that the duration of drug therapy could be an important factor in altering the amount of collagen. Farivar et al. have suggested a stimulatory role for the $\alpha$ l-adrenergic receptor in cardiac fibrosis in adult rats ${ }^{333}$. 
Mechanisms whereby the sympathetic nervous system affect cardiac collagen metabolism may, again, be related to (an interplay with) several factors. Effects independent of hemodynamic actions have been proposed, since low doses of catecholamines induced a significant increase in ventricular collagen, while systemic blood pressure and heart rate were unchanged ${ }^{292}$. An association of noradrenaline-induced fibrosis with myocyte necrosis has also been noticed, suggesting reparative fibrosis secondary to necrosis ${ }^{326,297}$. Since noradrenaline treatment of cardiac fibroblasts in vitro did not result in changes of collagen type I mRNA expression in these cells, it seems unlikely that noradrenaline has direct stimulating effects on collagen type I synthesis ${ }^{326}$. Indirect mechanisms, such as the noradrenaline-induced release of growth factors like TGF- $\beta_{1}$ (a regulator of collagen type I gene expression) may contribute to the noradrenaline-induced cardiac fibrosis ${ }^{326}$. Since $A C E$-inhibition and $A T_{1}$-receptor antagonism did not prevent isoprenaline-induced expression of collagen types I and III mRNA, the renin angiotensin system may not be important in $\beta$-adrenergic stimulated cardiac fibrosis in rats ${ }^{325}$. Other studies, however, have suggested a role for the AT, receptor in $\alpha 1$-adrenergic stimulated cardiac fibrosis ${ }^{333}$.

Far less research has focused on the role of the SNS in non-myocyte remodeling, but several studies suggest that catecholamines may represent mediators of growth of non-myocytes in the heart. A striking proliferation of interstitial cells was noted after several days of pressor doses of noradrenaline ${ }^{335}$. Both the $\beta$ adrenergic agent isoproterenol ${ }^{297}$ and the $\alpha$ l-adrenergic agent phenylepinephrine $^{333}$ stimulated DNA synthesis in both left and right ventricles, and virtually all nuclear labeling appeared to be limited to non-myocyte cells.

In vitro, noradrenaline induces proliferation of several strains of fibroblasts ${ }^{336,337}$, including cardiac fibroblasts ${ }^{326,338}$. In mouse $3 \mathrm{~T} 3$ cells, a mitogenic effect was observed predominantly through $\alpha 1$-receptor activation, whereas antimitogenic effects via $\alpha 2$ receptors have been suggested ${ }^{337}$. Activation of $\beta$-adrenergic receptors in cultured ventricular neonatal rat non-myocytes induced DNA synthesis $^{287}$. In addition, noradrenaline treatment resulted in hypertrophy of cultured cardiac fibroblasts, as determined by an increased expression of cytoskeletal actin mRNA ${ }^{326}$.

Several mechanisms have been proposed to underlie the effects on interstitial cell DNA synthesis induced by the adrenergic system, including a reactive response to myocyte necrosis ${ }^{297}$. There is also evidence for an autocrine / paracrine pathway; a combination of delayed stimulation of DNA synthesis together with 
induction of production of the growth factor TGF- $\beta$ and TGF- $\beta$ mRNA by adrenergic activation in cultured non-cardiomyocytes may point to autocrine / paracrine effects ${ }^{287,338}$. Noradrenaline treatment also enhanced the cardiac expression of TGF- $\beta$ mRNA in vivo ${ }^{326}$, supporting the concept that catecholamines may act indirectly on fibroblasts via an augmented secretion of growth factors like TGF- $\beta$.

As co-administration of the $\mathrm{AT}_{1}$ receptor antagonist losartan resulted in a significant decrease in interstitial cell proliferation induced by the $\alpha 1$ adrenergic agent phenylephrine in the rat heart, a cooperative interaction between an $\alpha 1$ adrenergic agonist and AngII has been proposed ${ }^{333}$. On the other hand, combined effects of these agents in heart tissue may not always be simply additive. Whereas both noradrenaline and AngII caused hyperplastic growth of cultured fibroblasts, combinations of both agents paradoxically inhibited proliferation, and rather induced fibroblast hypertrophy ${ }^{338}$. Thus, in conditions in which activation of the sympathetic and RAS axis occurs concomitantly, e.g. in myocardial infarction, effects on cardiac DNA synthesis by drugs interfering with these systems, might not be predictable

Together, the data point to a modulating effect of catecholamines in non-myocyte proliferation, with involvement of both $\alpha$-and $\beta$-adrenoceptors. This effect might, at least in part, be mediated via indirect patluways, like stimulated secretion of growth factors such as TGF- $\beta$ and interaction with the RAS.

\section{- Vascular compartment}

Our knowledge of effects of the sympathetic nervous system on coronary microvascular growth is rather limited. Sympathectomy has been reported to affect capillary growth during normal growth and hypertrophic cardiac growth, since chronic denervation during postnatal maturation increased myocardial capillary density in both spontaneously hypertensive and normotensive rats ${ }^{340}$. Similar findings have been obtained after chronic regional sympathectomy in hypertrophic hearts of adult renal hypertensive rabbits, but not in adult normotensive animals ${ }^{339}$. Moreover, prevention of sympathetic innervation did not influence the extent of vascularization of fetal hearts cultured in oculo (i.e. in the absence of significant hemodynamic load and mechanical forces $)^{341}$. These results suggest that enhanced myocardial capillary growth following denervation may be secondary to exaggerated hemodynamic and mechanical loading associated with hypertension and left ventricular hypertrophy ${ }^{341}$. Furthermore, since capillaries have been reported not to be innervated by sympathetic nerves ${ }^{340}$, the mechanisms for their 
enhanced growth after sympathectomy may be due to other factors, like enhanced blood flow and an increase in wall tension ${ }^{340,342}$.

Long-term inhibition of $\beta$-adrenoceptors by propranolol and metoprolol respectively, increased cardiac capillary density in young rabbits ${ }^{343}$ and in young normotensive rats ${ }^{340}$. On the other hand, sympathetic stimulation by dobutamine ( $\beta$ - and $\alpha$-adrenergic effect) also increased the capillary supply in adult rabbit hearts ${ }^{344}$. Long-term administration of the $\alpha$ l-adrenergic receptor blocker prazosin did not affect capillary density in the adult rat heart ${ }^{345}$.

Enhanced capillary growth by $\beta$-adrenergic blockade may be secondary to reduction of heart rate $\mathrm{r}^{340,346}$, whereas the increase of capillary density after adrenergic stimulation by dobutamine could be the result of mechanical factors connected with enhanced inotropic stimulation ${ }^{3+4}$.

To date, in vitro studies on the growth effects of adrenergic agents on cultured cardiac endothelial cells have not been described. In cultured bovine aortic endothelial cells, adrenaline stimulated DNA synthesis ${ }^{337}$, an effect that has been reported to be $\alpha 1$-adrenergic receptor mediated. The effects of the $\alpha 2$-agonist clonidine suggested an antimitogenic effect of $\alpha 2$-receptor stimulation in this study ${ }^{337}$.

Beta2-adrenergic receptor stimulation resulted in proliferation of human umbilical venous endothelial cells, an effect which appeared to be independent of cAMP, since direct activation of downstream effectors in the cAMP cascade even reduced cell proliferation ${ }^{3+47}$.

All in all, the sympathetic nervous system may be involved in the complex process of cardiac vessel growth in several, possibly indirect and sometimes opposing ways.

\subsection{Effects of SNS interventions in clinical studies}

Benefit of $\beta$-blocker therapy as a secondary preventive therapy for myocardial infarction has been demonstrated by data from a large number of trials, which showed a significant mortality reduction ${ }^{348-350}$. Also a reduction of the risk of reinfarction has been demonstrated ${ }^{348}$. Thus, $\beta$-blockers have an accepted role in the secondary prevention of myocardial infarction ${ }^{351}$.

Reports published in the seventies from Sweden ${ }^{352,353}$ demonstrating the possible beneficial effects of $\beta$-blockade in chronic heart failure in congestive cardiomyopathy were followed by many studies. Clinical trials of several different $\beta$-blockers have shown that these drugs can produce hemodynamic and symptomatic improvement in chronic heart failure due to non-ischemic and 
ischemic cardiomyopathy ${ }^{354-359}$. Non-selective agents without intrinsic sympathomimetic activity appeared to have the maximal potential benefit ${ }^{3+10 !}$. A large multicentre heart failure trial has indicated that the addition of carvedilol, a vasodilating $\beta$-blocker, to conventional therapy is associated with a decrease in mortality ${ }^{361}$. Serial echocardiography has shown that carvedilol treatment in patients with ischemic heart failure is associated with a reduction in left ventricular dimensions ${ }^{362}$.

On the other hand, the use of potent inotropic drugs, like $\beta$-adrenergic agonists (dobutamine) and phosphodiesterase inhibitors (milrinone), were found to worsen survival in patients with congestive heart failure ${ }^{363,364}$.

\section{Outline of this thesis}

The rat infarct model is a well established experimental model of cardiac failure, which is associated with neurolumoral activation of the renin-angiotensin-system and the sympathetic nervous system. In this model alterations in cardiac structure (cardiac remodeling) have been examined extensively.

\section{Hypothesis:}

The aim of the present thesis is to investigate structural changes which occur in the interstitium of the non-infarcted part of the myocardium after infarction. Since after myocardial infarction interstitial cells are stimulated to enhance DNA synthesis $^{68}$, and the interstitial cell population consists mainly of fibroblast likecells and endothelial cells ${ }^{13}$, we postulated that both cell types may participate in the increased DNA synthesis after myocardial infarction. Furthennore, since ACE inhibition $^{68}$ and $\mathrm{AT}_{1}$ receptor antagonism ${ }^{198}$ inhibit interstitial cell DNA synthesis completely or only to a minor extent respectively, we hypothesized that activation of the renin-angiotensin-system is associated with enhanced DNA synthesis by endothelial and/or non-endothelial cells through a non- $\mathrm{AT}_{1}$ receptor mechanism, possibly through the $\mathrm{AT}_{2}$ receptor. Furthermore, because of the close interaction between the renin-angiotensin-system and the sympathetic nervous system it is possible that effects of the activated renin-angiotensin-system are mediated through interaction with the activated sympathetic nervous system following infarction. Moreover, the sympathetic nervous system per se has been implicated in modulating cardiac structure, including the interstitium. Thus, we hypothesized 
that activation of the sympathetic nervous system is associated with changes in interstitial cell DNA synthesis and collagen content after myocardial infarction.

The answer to the question which particular interstitial cell type is involved in the infarct-induced increase in DNA synthesis will be addressed in chapter 2. A method will be described by which DNA-synthesizing endothelial cells can be visualized in paraffin embedded rat heart tissue.

Chapter 3 will investigate the effects of early treatment with ACE-inhibitors on post-infarction DNA synthesis of endothelial and non-endothelial cells. Also, the functional consequences of $\mathrm{ACE}$-inhibition on endothelial proliferation, reflected by the effect on maximal coronary flow, will be determined.

Having determined the effects of ACE-inhibition on DNA synthesis in endothelial cells and non-endothelial cells, chapter 4 will outline the effects of $\mathrm{AT}_{1}$ - and $\mathrm{AT}_{2}$ receptor blockade on these parameters. The effects of blockade of both these AngII receptor subtypes on hemodynamic parameters will also be studied in parallel experiments.

Evidence exists that the sympathetic nervous system itself might be a factor in the process of remodeling of the cardiac interstitium. However, the effects of drugs interfering with the sympathetic nervous system on interstitial remodeling early after infarction are not known. Therefore, in chapter 5 and 6 the effects of early treatment with different pharmacological agents either stimulating or reducing the adrenergic drive on cardiac DNA synthesis and collagen content will be described.

In chapter 5 the effects of adrenergic stimulation by dobutamine ( $\alpha$ l- and $\beta$ adrenergic) will be reported. In a parallel study the effects of milrinone (phosphodiesterase III inhibitor) will be studied.

The effects of inhibition of $\beta$-adrenoceptors by propranolol and inhibition of sympathetic outflow by clonidine and moxonidine will be outlined in chapter 6 .

Finally, in chapter 7 the data obtained in the studies described in the previous chapters will be discussed. 


\section{References}

1. Braunwald E: Heart failure, in Fauci AS, Braunwald E, et al (eds): Harrison's principles of internal medicine, fourteenth ed. New York, McGraw-Hill, 1998, vol 1, pp. 1287-1298.

2. The SOLVD Investigators: Effect of enalapril on survival in patients with reduced left ventricular ejection fractions and congestive heart failure. N Engl J Med 1991;325:293302.

3. The SOLVD Investigators: Effect of enalapril on mortality and the development of heart failure in asymptomatic patients, with reduced left ventricular ejection fractions. $N$ Engl J Med 1992:327:685-692.

4. Packer M: Beta-blockade in heart failure. Basic concepts and elinical results Am f Hyperiens 1998:11:23S-37S.

5. Bonneux L, Looman CW, Barendregt JJ, Van der Maas PJ: Regression analysis of recent changes in cardiovascular morbidity and mortality in The Netherlands. Br Med $J$ 1997:314:789-792

6. Pfeffer MA. Braunwald E: Ventricular remodeling after mocardial infarction. Experimental observations and clinical implications. Circulation 1990:81:1161-1172.

7. Dacmen MJAF. Snits JFM: The wound healing response after myocardial infarction: structural and pharmacological aspects, in Weber KT (ed): Wound healing in cardiorascular disease. New-Y̌ork. Arnonk. Futura Publishing Company Inc., 1995, pp. $23-33$.

8. Ginaton LE. Conant R. Rodrigues DM, Laks MM: Functional significance of hypertrophy of the noniniareted mycordium sfier myocardial survival in lumans. Circulation $1989: 80: 816-822$.

9. Amersa P. LiP. Zhang X, Olivetti G. Capasso JM: Ischaemic mocardial injury and ventricular remodelling. Cardiovasc Res
1993:27:145-157.

10. Pfeffer JM, Pfeffer MA. Fleicher PJ. Braunwald E: Progressive ventricular remodeling in rat with myocardial infarction. Am J Physiol 1991:260:H1406-H1414.

11. Katz AM: Cardiomyopathy of overload. A major determinant of prognosis in congestive hear failure $N$ Engl J Med 1990:322:100. 110.

12. Pfeffer MA. Pfeffer M, Steinberg C, Finn P Sunival after an experimental myocardial infarction: beneficial effects of long-term therapy with captopril. Circulation 1985;72:406-412.

13. Weber KT, Anversa P, Armstrong PW, Brilla CG. Burnet JC Jr. Cruickshank IM. Devereux RB. Giles TD. Korsgaard N, Leier $\mathrm{CV}, \mathrm{et}$ al: Remodeling and reparation of the cardiovascular sysiem. J Am Coll Cardiol 1992:20:3-16.

14. Zak R: Cell proliferation during cardiac growth. Am $J$ Cardiol 1973;31:211-219.

15. Frank JS. Langer GA: The myocardial interstitium: Its structure and its role in ionic exclange. J Cell Biol' 1974;60:586-601.

16. Caulfield JB. Borg TK: The collagen network of the heart. Lab Invest 1979:40 364-372.

17. Rotinson TF, Collen-Gould L, Factor SM: Skeletal framework of mammalian hear muscle. Arrangernent of inter- and pericellular connective tissue structures. $L a b$ Imest 1983:49:482-498.

18. Weber KT, Sun Y. Tyagi SC, Cleuljens JP: Collagen network of the myocardium: function. structural remodeling and regulatory mechanisms. J Mol Cell Cardid $1994: 26: 279-292$

19. Weber K.T: Cardiac interstitium in lealth and disease: the fibrillar collagen network. $J \mathrm{Am}$ Coll Cardiol 1989:13:1637-1652. 
20. Eghbali M, Blumenfeld OO, Seifter S, Buttrick PM. Leinwand LA, Robinson TF, Zern MA. Giambrone MA: Localization of types I,III and IV collagen mRNAs in rat heart cells by in situ hybridization. $J$ Mol Cell Cardiol 1989;21:103-133.

21. Chapman D. Weber KT, Eghbali M: Regulation of fibrillar collagen types I and III and basement membrane type IV collagen gene expression in pressure overloaded rat myocardium. Circ Res 1990:67:787-794.

22. Olivetti G, Capasso JM, Sonnenblick EH, Anversa P: Side-to-side slippage of myocytes participates in ventricular wall remodeling acutely after myocardial infarction in rats. Circ Res 1990;67:23-34.

23. Anversa P, Olivetti G, Meggs LG, Sonnenblick EH, Capasso JM: Cardiac anatomy and ventricular loading after myocardial infarction. Circulation 1993;87.(Suppl. VII):22-27.

24. Mulder P, Devaux B, Richard V, Henry J-P, Wimart M-C. Thibout E, Mace B, Thuillez C: Early versus delayed angiotensin-converting enzyme inhibition in experimental chronic hear failure. Circulation 1997:95:1314-1319

25. Baur LH, Schipperheyn JJ, Van der Wall EE. Van der Velde EA. Schalij MJ, Van Eck-Smit BL, Van der Laarse A. Voogd PJ, Sedney MI. Reiber JH. Bruschke AV: Beneficial effect of enalapril on left ventricular remodelling in patients with severe redidual stenosis after acute anterior wall infaretion. Eur Heart $J$ 1997:18:1313-1321.

26. Pfeffer MA, Lamas GA, Vaughan DE, Parisi $A F$. Braunwald $E$ : Effect of captopril on progressive ventricular dilatation after myocardial infarction. $N$ Engl $\mathrm{J} \mathrm{Med}$ 1988:319:80-86.

27. Capasso JM, Li P, Zhang X, Anversa P: Heierogeneity of ventricular remodeling after acute myocardial infarction in rats. $A m J$ Physiol 1992:262:H486-H495.
28. Pfeffer MA, Braunwald E, Moye LA, Basta L, Brown EJ, Cuddy TE, Davis BR, Geltman EM, Goldman S, Flaker GC, Klein M, Lamas GA, Packer M, Rouleau J, Rouleau $\mathrm{L}$, Rutherford J. Wertheimer JH, Hawkins CM, The SAVE Investigators: Effect of captopril on mortality and morbidity in patients with left ventricular dysfunction after myocardial infarction: results of the Survival and Ventricular Enlargement Trial. N Engl J Med 1992:327:669-677.

29. Jeremy RW, Hackworthy RA, Bautovich G, Hutton BF. Harris PJ: Infarct artery perfusion and changes in left ventricular volume in the month after actute myocardial infarction. $J$ Am Coll Cardiol 1987:9:989-995.

30. Leung W-H. Lau C-P: Effects of severity of residual stenosis of the infarct related coronary antery on left ventricular remodeling and function after myocardial infarction [abstract]. Circulation 1991:84(suppl.II):476.

31. Fishbein MC, Maclean D, Maroko PR: Experimental myocardial infarction in the rat. Am J Pathol 1978:90:57-70.

32. Kajstura J, Cheng W. Reiss K. Clark WA, Sonnenblick EH. Krajewski S, Reed. JC, Olivetti G. Anversa P: Apoptotic and necrotic myocyte cell death are independent contributing variables of infarct size in rats. Lab Invest 1996:74:86-107.

33. Bialik S. Geenen DL, Sasson IE, Cheng R, Homer JW, Evans SM. Lord EM. Koch CJ. Kitsis RN: Myocyte apoptosis during acute myocardial infarction in the mouse localizes to hypoxic regions but occurs independently of p53. J Clin Invest 1997:100:1363-1372.

34. Akiyama K. Gluckman TL. Terhakopian A, Jinadasa PM. Narayan S, Singaswamy $S$. Massey B. Bing RJ: Apoptosis in experimental myocardial infarction in situ and in the perfused heart in vitro. Tissue \& Cell 1997:29:733-743.

35. Veinot JP. Gattinger DA. Fliss H: Early apoptosis in human myocardial infarcts. Hum Pathol 1997:28:485-492. 
36. Takemura G. Ohno M, Hayakawa Y, Misao J, Kanoh M, Ohno A, Uno Y, Minatoguchi S, Fujiwara T, Fujiwara $\mathrm{H}$ : Role of apoptosis in the disappearance of infiltrated and proliferated interstitial cells after myocardial infarction. Circ Res 1998;82:1130-1138.

37. Takahashi S, Barry AC, Factor SM: Collagen degradation in ischaemic rat hearts. Biochem $J$ 1990;265:233-241.

38. Cleutjens JPM, Kandala JC, Guarda E, Weber $\mathrm{KT}$ : Regulation of collagen degradation in the rat myocardium after infarction. $J \mathrm{Mol} \mathrm{Ce} ! l$ Cardiol 1995:27:1281-1292.

39. Weisman HF. Bush DE, Mannisi JA. Bulkley BH: Global cardiac remodeling after acute myocardial infarction: a study in the rat model. $J$.4m Coll Cardiol 1985:5:1355-1362.

40. Vannan MA. Tavlor DJE: Ventricular remodeling after myocardial infarction. $\mathrm{Br}$ Heart .J 1992:68:257-259.

41. Schuster EH. Bulkley BH: Expansion of transmural myocardial infarction: A pathophysiologic factor in cardiac rupture Circulation 1979:60:1532-1538.

42. Weber $\mathrm{KT}$ : Extracellular matrix remodeling in heart failure. Circulation 1997:96:40654082.

43. Sun Y: Local angiotensin II and myocardial fibrosis. Review. Athanc Exp A/ed Biol 1997:432:55-61.

44. Cleutjens JPM. Verluyien MJA. Smits JFM. Daemen MJAP: Collagen remodeling after myocardial infarction in the rat heart. $A \mathrm{~m} \mathrm{~J}$ Pathol 1995:147:325-338.

45. Weber KT. Sun Y, Katwa LC: Myofibroblasts and local angiotensin 11 in rat cardiac tissue repair. Ini J Biochem Cell Biol 1997;29:3142.

46. Tyagi SC, Matsubana L. Weber KT: Extraction and estimation of collagenase(s) activity by zyinograply in microquantitics of rat myocardium. Clin Biochem 1993:26:191-
198.

47. Vracko R, Thorning D: Contractile cells in rat myocardial scar tissuc. Lab Invest 1991,65:221-227.

48. Willems IEMG. Havenith MH, De Mey JGR, Daemen MJAP: Alpha smooth muscle actin positive cells in healing human myocardial scars. Am J Pathol 1994:145:868-875.

49. Le Noble FAC, Schreurs NHJS, Van Straaten HWM. Slaaf DW. Sinits JFM. Rogg H, Sinuijker-Boudier HAJ: Evidence for a novel angiotensin II receptor involved in angiogenesis in chick embryo chorioallantoic membrane. Am J Physiol 1993;264:R460R465.

50. Willems IEMG. Arends J-W, Daemen MJAP: Tenascin and fibronectin expression in healing human myocardial scars. $J$ Pathol 1996:179:321-325.

51. Casscells W. Kimura H. Sanchez JA. Yu Z-X Ferrans VJ: Imınunohistochemical study of fibronectin in experimental myocardial infarction. Am J Pathol 1990:137:801-810

52. Ulrich MMW. Janssen AMH. Dacmen MJAP. Rappaport L. Samuel J-L. Contard F. Sunits JFM. Cleutjens JPM: Increased expression of fibronectin isoforms after myociardial infarction in rats. J Mel Cell Cardiol 1997:29:2533-25+3

53. Anversa P. Beghi C. Kikkawa Y. Oliveti G Myocardial response to infarction in the rat. Morphometric measurement of infiart sise and myocyte cellular hypertrophy. $A m J$ Pathol 1085:118.484-4')2.

54. Anversa P. Loud AV. Levicky V. Guideri G: Left ventricular failure induced by myocardial intarction. II. Tissue morphomelry. $4 \mathrm{~m} \mathrm{~J}$ P'hiswl 1985:2+8:H88:3-H889

55. Xie Z. Gano M. Batra S. Koyama T: The capillarity of left ventricular tissuc of rats subjected to coronary artery occlusion. Cardiovasc Res 1997:33:671-676. 
56. Volders PGA. Willems IEMG, Cleutjens JPM, Arends JW, Havenith MG. Daemen MJAP: Interstitial coilagen is increased in the non-infarcted human myocardium after myocardial infarction. J Mol Cell Cardiol 1993:25:317-323.

57. Liu Y-H, Yang X-P. Sharov VG. Nass O. Sabbah HN. Peterson E. Carretero OA: Effects of angiolensin-converting enzyme inhibitors and angiotensin II type 1 receptor antagonists in rats with heart failure. $J \mathrm{Clin}$ Invest 1997:99:1926-1935.

58. McDonald KM. Chu C. Francis GS. Carlyle W. Judd DL. Hauer K. Hartınan M. Coln JN: Effect of delayed interiention with ACEinhibitor therapy on myocyle hypertrophy and growth of the cardiac interstitium in the rat model of myocardial infarction. J Mol Cell Cardiol 1997:29:3203-3210.

59. Makino N, Hata T, Sugano M, Dixon IMC. Yanaga $T$ : Regression of hypertrophy after myocardial infarction is produced by the chronic blockade of angiotensin type 1 receptor in rats. J Mol Cell Cardiol 1996:28:507-517.

60. Cittadini A. Grossman JD. Napoli R, Katz SE. Stroemer H. Smith RJ. Clark R, Morgan JP. Douglas PS: Growth hormone attenuates early left ventricular remodeling and improves cardiac function in rats with large myocardial infarction. $J \mathrm{Am}$ Coll Cardiol 1997:29:1109-1116.

61. Francis GS. Cohn JN: Heart failure: mechanisms of cardiac and vascular dysfunction and the rationalc for plarmacologic intervention. Faseb $J$ 1990;4:30683075 .

62. Lompre AM. Mercadicr JJ. Schwarly K: Changes in gene expression during cardiac growth. Int Rev Cytol 1991:124:137-186.

63. Anversal P. Ricci R. Olivettı G: Quantitative structural analysis of the myocardiun during phisiologic growth and induced cardiac hypertrophy: a review. I Am coll curetiol 1986:7:1140-[1+9.
64. Li F, Wang X, Capasso JM, Gerder AM: Rapid transition of cardiac myocytes from hyperplasia to hypertrophy during postnatal development. J Moi Cell Cardiol 1996:28:1737-1746.

65. Reiss K, Kajstura I. Zlang X. Li P, Szoke E, Oliveti G. Anversa P: Acute myocardial infarction leads 10 upregulation of the IGF-1 autocrine systcm, DNA replication, and nuclear mitotic division in the remaining viable cardiac myocytes. Exp Cell Res $1994: 213: 463-472$

66. Capasso JM. Bruno S. Clieng W. Li P. Rodgers R, Darzynkiewicz Z, Anversa P: Ventricular loading is coupled with DNA synthesis in adult cardiac myocytes after acute and chronic myocardial infarction in rats. Circ Res 1992:71:1379-1389.

67. Kajstura J, Zlang X. Reiss K, Szoke E, Li P. Lagrasta C. Cheng W, Darynkiewicz Z. Olivetti G. Anversa P: Myocyte cellular lyperplasia and myocyte cellular hypertrophy contribute to chronic ventricular remodeling in coronary artery narrowing-induced cardiomyopathy in rats. Circ Res 1994:74:383-400.

68. Van-Krimpen C. Smits JF. Cleutjens JP. Debets JJ. Schoemaker RG. Struyker-Boudier HA. Bosman FT, Daemen MJ: DNA synthesis in the non-infarcied cardiac interstitium after left coronary artery ligation in the rat: effects of captopril. JA/ol Cell Cardiol 1991:23:1245-1253.

69. Linzbach AJ: Heart failure from the point of viets of quantitative anatomy. Am.J Cardiol $1960.5370 \cdot 382$.

70. Grajek S. Lesiak M. Pyda M. Zajac M, Paradowski S. Kacmarek E: Hypertroplyy or hyperplasia in cardiac muscle. Post-mortem human morphometric study. Eur hearl.J 1993:14:40-47.

71. Oliveti G. Ricei R. Anversa P: Hyperplasia of myocyte nuclei in long-term cardiac hypertrophy in rats. $I$ Clin hinest $1987,80: 1818-1821$. 
72. Anversa P, Palackal T, Sonnenblick EH. Olivetti G, Meggs LG, Capasso JM: Myocyte cell loss and myocyte ceilular hyperplasia in the hypertrophied aging rat heart. Circ Res 1990;67:871-885.

73. Anversa P, Fitzpatrick D, Argani S, Capasso JM: Myocyte mitotic division in the aging mammalian rat heart. Circ Res 1991;69:1159-1164.

74. Olivetti G, Quaini F, Sala R, Lagrasta C, Corradi D, Bonacina E, Gambert SR, Cigola E, Anversa P: Acule myocardial infarction in humans is associated with activation of progranmed myocyte cell death in the surviving portion of the heart. $J \mathrm{Mol} \mathrm{Cell}$ Cardiol 1996;28:2005-2016.

75. Olivetti G, Abbi R. Quaini F, Kajstura J, Cheng W. Nitahara JA, Quaini E, Di Loreto C, Beltrami CA, Krajewski S, Reed JC, Anversa P: Apoptosis in the failing human heart. N Eng/ J Med 1997:336:1131-1141.

76. Young RL, Gundlach AL, Louis WJ: Altered cardiac hormone and contractile protein messenger RNA levels following left ventricular myocardial infaretion in the rat: an in situ hybridization histochemical study. Cardiovasc Res 1998;37:187-201.

77. Schwartz K. Boheler KR, De La Bastie D. Lompre AM. Mercadier Jy: Switches in cardiac muscle gene expression as a result of pressure and volume overload. Am J Physiol 1992;262:R364-R369.

78. Laser A, Ingwall JS, Tian R, Reis I. Hu K. Gaudron P. Erll G, Neubauer S: Regional biochemical remodeling in non-infarted tissue of rat heart post-myocardial infarction. $J$. $/$ ol Cell Cardiol 1996:28:1531-1538.

79. Yamaguchi F, Sanbe A, Takeo S: Effects of long-term treatment with trandolapril on sarcoplasmic reticulum function of cardiac muscle in rats with chronic heart failure following myocardial infarction. Br $J$ Pharmacol 1998:123:326-334.
80. Katz AM: Heart failure. in Fozzard HA (ed): The heart and cardiovascular system (SG WG 202), 2ndl ed. New York, Raven Press, 1992, pp. $333-353$.

81. Doering CW. Jalil JE, Janicki JS, Pick R. Aghili S, Abrahams C. Weber KT: Collagen network remodelling and diastolic stiffiness of the rat left ventricle with pressure overload lypertrophy. Cardiovasc. Res 1988;22:686695 .

82. Covell JW: Factors influencing diastolic function. Possible role of the exiracellular matrix. Circulation 1990;81:1I1155-111158.

83. Whittaker P: Unravelling the mysteries of collagen and cicatrix after myocardial infarction. Cardiorasc Res 1995;29:758-762.

84. Ju H, Zhao S. Jassal DS. Dixon IMC: Effect of ATI receplor blockade on cardiac collagen remodeling after myocardial infarction. Cardiovase Res 1997:35:223-232.

85. Adler C-P, Neuburger M, Herget GW, Muchlbach D: Regeneration processes in human myocardium after acute ischacmiaquantitative determination of DNA. cell number and collagen content. Virch Arch 1997:430:149-153.

86. Marijianowski MMH. Teeling P. Becker AE: Remodeling after myocardial infaretion in humans is not associated with interstitial fibrosis of noninfarcled myocardium. $J . A m$ Coll Cardhol 1997:30:76-82.

87. Volders PG. Daemen MJ: Interstitial fibrosis and angiotensin-converting-enzyme inhibition in patients with end-stage myocardial infarction. $J$ A $m$ Coll Cardiol 1998:32:552553.

88. Boluyt MO. Bing OHL: The lonely failing heart: a case for ECM genes. Cordiovasc Res $1995 ; 30: 835-840$.

89. Taylor K. Patten R. Smith JJ, Aronovitz M. Gao W. Wight J. Salomon RN, Konstam MA Divergent effects of angiotensin converting enryme inhibition and angiotensin receptor 
antagonism on cell proliferation, collagen deposition and ventricular remodeling following myocardial infarction in rats (Abstract). Circulation 1995;92(Suppl.I):I-25

90. Hudlicka O, Brown M, Egginton S: Angiogenesis in skeletal and cardiac muscle. Physiol Rev 1992;72:369-417.

91. Roberts JT, Wearn JT: Quantitative changes in the capillary-muscle relationship in human hearts during normal growth and hypertrophy. Am Heart J 1941:21:617-633.

92. Anversa P., Sonnenblick EH: Ischemic cardiomyopathy: pathophysiologic mechanisms. Prog Cardiovasc Dis 1990;33:49-70.

93. Turek Z, Grandıner M, Kubat K, Ringnalda BEM, Kreuzer F: Arlerial blood gases, muscle fiber diameter and intercapiliary distance in cardiac hypertrophy of rats with an old myocardial infarction. Pfugers Archiv 1978:376:209-215.

94. Anversa P, Beghi C, Kikkawa Y, Olivetti G: Myocardial infarction in rats. Infarct size, myocyte hypertrophy and capillary growth. Circ Res 1986:58:26-37.

95. Anversa P. Loud AV. Levicky V. Guideri G: Left ventricular failure induced by myocardial infarction. I. Myocyte hypertrophy. $4 \mathrm{~m} \mathrm{~J}$ Physiol 1985:248:H876-H882.

96. Anversa P, Sonnenblick EH: Ischemic Cardiomyopathy: pathoplysiologic mechanisms. Prog Cardiovasc Dis $1990 ; 33: 49-70$.

97. Olivetti G. Capasso JM. Mcggs LG, Sonnenblick EH. Anversa P: Cellular basis of chronic ventricular remodeling after myocardial infarction in rats. Circ Res 1991:68:856-869.

98. Sladek T. Sladkova J, Kolar F, Papousek F. Cicutti N. Korecky B. Rakusan K: The effect of ATl receptor antagonist on chronic cardiac response to coronary artery ligation in rats. Cardiovase Res 1996:31:568-576.
99. Przyklenk K, Groom AC: Microvascular evidence for a transition zone around a chronic myocardial infarct in the rat. Can $J$ Physiol Pharmacol 1983;61:1516-1522.

100. Nelissen-Vrancken HJMG, Debets JJM, Schnoeckx LHEH, Daemen MJAP, Smits JFM: Time-related normalization of maximal coronary flow in isolated perfused hearts of rats with myocardial infarction. Circulation 1996;93:349-355.

101. Gorge G, Schmidt T, Ito BR, Pantely GA, Schaper W: Microvascular and collateral adaptation in swine hearts following progressive coronary artery stenosis. Basic Res Cardiol 1989;84:524-535.

102. Schaper W: Coronary collateral development: concepts and hypotheses, in Schaper W. Schaper J (eds): Collateral circulation: heart. brain, kidney, limbs. Dordrecht, the Netherlands, Kluwer Academic Publishers, 1992, pp. 41-64.

103. Schaper W: New paradigms for collateral vessel growth. Basic Res Cardiol 1993:88:193-198.

104. Zimmermann R, Arras M, Ulmann C, Strasser R, Sack S, Mollnau H, Schaper J. Schaper W: Time course of mitosis and collateral growth following coronary microembolization in the porcine heart. Cell Tissue Res 1997;287:583-590.

105. Packer M: New concepts in the pathophysiology of hean failure: beneficial and deleterious interaction of endogenous haemodynamic and neurohormonal interactions. $J$ Im Med 1996;239:327-333.

106. Dzau VJ: Local expression and pathophysiological role of renin-angiotensin in the blood vessels and heart, in Grobecker $\mathrm{H}$, Heusch G、 Straucr BE (eds): Angiotensin and the Heart. Supplement to Basic Research in Cardiology. Darmstadt, Steinkopff Verlag. 1993, vol 88, Suppl.1, pp. 1-14.

107. Lindpaintner K, Ganten D: The cardiac reninangiotensin system. An appraisal of present 
experimental and clinical evidence. Circ Res 1991:68:905-920.

108. Reid IA: Interactions between AngII, sympathetic nervous system, and baroreceptor reflexes in regulation of blood pressure. $\mathrm{Am} \mathrm{J}$ Physiol 1992:262:E763-E778.

109. Zimmerman BG: Adrenergic facilitation by angiotensin: does it serve a physiological function. Clin $S_{c i}$ 1981;60:343-348.

110. Goodfriend TL: Angiotensins. A family that grows from within Hypertension 1991:17:139-140.

111. Ferrario CM. Chappell MC, Tallant EA Brosnihan KB. Diz DI: Counterregulatory actions of angiotensin-(1-7). Hypertension 1997:30:535-541.

112. Metsarimric KP. Stoll M. Gohlke P. Paul M. Unger T: Angiotensin II is antiproliferative for coronary endothelial cells in vitro. Pharm Pharmacol Lett 1942:2.150)-152.

113. lyer SN, Chappell MC. Averill DB. Diz DI. Ferrario CM: Vasodepressor actions of angiotensin-(1-7) unmasked during combined treatment with lisinopril and losartan. Hypertension 1998:31:699-705.

114. Freeman EJ, Chisolm GM, Ferrario CM, Tallant A: Angiotensin-(1-7) inhibits vascular smooth muscle cell growth. Hypertension 1996:28: 104-108.

115. Erdos EG: Angiotensin I converting enzyme and the changes in our concepts through the years. Lewis K. Dahl memorial lecture. Hypertension 1990: 16:363-370.

116. Becker RHA, Wiemer G, Linz W Preservation of endothelial function by ramipril in rabbits on a long-term atherogenic diet. J Cardiovasc Pharmacol 1991:18(Suppl.2):S110-\$115.

117. Urata H. Kinoshita A, Misono KS. Bumpus FM, Husain A: Identification of a highly specific chymase as the major angiotensin IIforming enrame in the human heart. $J$ Biol
Chem 1990:265:22348-22357.

1118. Wolny A, Clozel J-P, Rein J, Mory P. Vogt P, Turino M, Kiowski W. Fischli W: Functional and biochemical analysis of angiotensin IIforming pathways in the human heart. Circ Res 1997;80:219-227.

119. Daemen MJAP, Urata H: Healing human myocardial infarction associated with increased chymase immunoreactivity. In: Heart and vessels. Proc. of the International Session at the 61st Annual Scientific Meeting of the Japanese Circulation Society "Circulation 97". Tokyo, Springer-Verlag, 1997, vol Suppl. 12.

120. Smits JF, Passier RC. Daemen MJ: Should we aim at tissue renin-angiotensin systems. Pharm World Sci 1998;20:93-99.

121. Lindpaintner K. Jin M. Wilhelm MJ. Suzuki F. Liny W. Schoelkens BA. Ganten D: Intracardiac generation of angiotensin and its physiological role. (irtulatiem I988:7? (Suppl.I): I-18

122. Pissier RCJJ. Smits JFM, Verluyten MJA. Studer R. Drexler H. Daemen MJAP: Activation of angiotensin-converting-enzyme expression in the infarct zone following myocardial infarction. Am J Physiol 1995:269:H1268-H1276.

123. Passier RCJJ, Smits JFM, Verluyten MJA, Daemen MJAP: Expression and localization of renin and angiotensinogen in rat heart after inyocardial infarction. . I $J$ Phisiol 1990:271:H1040-H1048

124. Schunkert H, Dzau VJ, Tang SS. Hirsch AT, Apsicin CS. Lorell BH: Increased rat cardiac angiotensin converting enzyme activity and mRNA expression in pressure overload lcft ventricular hypertrophy. Effects on coronary resistance, contractility, and relaxation. $J$ Clin Invest 1990;86:1913-1920.

125. Lindpaintner $\mathrm{K}$. Jin $M$. Nicdermaier $N$. Wilhelm M. Ganten D: Cardiac angiotensinogen and its local activation in the isolated perfused beating heart. Circ Res 
$1990 ; 67: 564-573$.

120. Dostal DE, Rothblum KN, Chernin MI, Cooper GR, Baker KM: Intracardiac detection of angiotensinogen and renin: a localized renin-angiotensin system in neonatal rat heart. Am J Physiol 1992;263:C838-C850.

127. Nio Y, Matsubara H, Murasawa S, Kanasaki M, Inada M: Regulation of gene transcription of angiotensin Il receptor subtypes in myocardial infarction. $J$ Clin Invest 1995;95:46-54.

128. Dostal DE, Rothblum KN, Conrad KM, Cooper GR, Baker KM: Detection of angiotensin I and II in cultured rat cardiac myocytes and fibroblasts. Am $J$ Physiol 1992;263:C851-C863.

129. Sadoshima J, Xu Y, Slayter HS, Izumo S: Autocrine release of angiotensin II mediates stretch-induced hypertrophy of cardiac myocyles in vitro. Cell 1993;75:977-984.

130. Katwa LC, Campbell SE, Tyagi SC, Lee SJ, Cicila GT, Weber KT: Cultured myofibroblasts generate angiotensin peptides de novo. $J \mathrm{Mol}$ Cell Cardiol 1997;29:13751386.

131. Fischer TA. Ungureanu-Longrois D. Singlı K, De Zengotila J. De Ugarte D. Alali A. Gadbut AP, Lee M-A. Balligand J-L. Kifor I. Smith TW, Kelly RA: Regulation of bFGF expression and Ang 11 secretion in cardiac myocytes and microvascular endothelial celis. Am J Physiol 1997;272:H958-H968.

132. Timmermans PB, Wong PC. Chiu AT. Herblin WF, Benfield P, Carini DJ. Lee RJ. Wexler RR. Saye JA. Smith RD: Angiotensin II receptors and angiotensin II receptor antagonists. Pharmacol Rev 1993:45:205251.

133. Bumpus FM. Catt KJ. Chiu AT, DeGasparo M, Goodfriend T, Husain A. Peach MJ. Taylor DG, Timmermans PBMWM: Nomenclature for angiotensin receptors. A report of the Nomenclature Committee of the Council for High Blood Pressure Research.
Hypertension 1991;17:720-721.

134. Kakar SS, Sellers JC, Devor DC, Musgrove LC, Neill JD: Angiolensin Il type-1 receptor subtypes $\mathrm{CDN}$ as differential tissue expression and hormonal regulation. Biochem Biophys Res Commun 1992;183:1090-1096.

135. Grady EF, Sechi LA, Griflin CA, Schambelan M. Kalinyak JE: Expression of AT2 receptors in the developing rat fetus. $J$ Clin Invest 1991;88:921-933.

136. Tsutsumi K, Stromberg C, Viswanathan M, Saavedra JM: Angiotensin-II receptor subtypes in fetal tissue of the rat:Autoradiography, guanine nucleotide sensitivity, and association with phosphoinositide hydrolysis. Endocrinology 1991:129:1075-1082.

137. Sechi LA, Griffin CA, Grady EF, Kalinyak $\mathrm{JE}$, Schambclan M: Characterization of angiotensin II receptor subtypes in rat heart. Circ Res 1992;71:1482-1489.

138. Chang RS. Lotti VJ: Angiotensin receptor subtypes in rat, rabbit and monkey tissues: Relative distribution and species dependency. Life Sei 1991:49:1485-1490.

139. Feolde E. Vigne P. Frelin C: Angiotenin II receptor subtypes and biological responses in the rat hean, $\mathrm{M}$ Mol Cell Cardiol 1993;25:1359-1367.

140. Regitz-Zagrosek V, Friedel N, Heymann A, Bauer P. Neuss M, Rolfs A. Steffen C, Hildebrand A, Hetzer R, Fleck E: Regulation. chamber localization, and subtype distribution of angiotensin II receplors in human hearts. Circulation 1995;91:1461-1471.

141. Rogg H, de Gasparo M, Graedel E. Stulz P, Burkan F. Eberhard M, Eme P: Angiotensin II-receptor subtypes in human atria and evidence for alterations in patients with cardiac dysfunction. Eur Heart $J$ 1996;17:1112-1120.

142. Suzuki J, Matsubara H, Urakami M. Inada M: Rat angiotensin II (type 1A) receptor mRNA 
regulation and subtype expression in myocardial growth and hypertiophy. Circ Res 1993;73:439-447.

143. Lopez JJ, Lorell BH, Ingelfinger JR, Weinberg EO, Schunkert H, Diamant D, Tang S-S: Distribution and function of cardiac angiotensin AT1- and AT2-receptor subtypes in hypertrophied rat hearts. $A m J$ Physiol 1994; 267:H844-H852.

144. Asano K, Dutcher DL, Port JD. Minobe WA, Tremmel KD, Roden RL, Bohlmeyer TJ, Bush EW, Jenkin MJ, Abraham WT. Raynolds MV, Zisman LS. Perryman MB. Bristow MR: Sclective downregulation of the angiotensin II AT l-receptor subtype in failing human ventricular myocardium. Circulation 1997:95: 1 193-1200

145. Rogg H, DcGasparo M. Gradel E, Stulz P. Erne P: Identification of angiotensin-IIreceptor subtypes in human atrial tissue. Eur Heart J 1991:12(abstract suppl.):224.

146. Wolf K, Bruna RD, Bruckschlegel G, Schunken H, Riegger GAJ, Kurtz A: Angiolensin II receplor gene expression in hypertrophied left ventricles of rat hearts. $J$ Hypertens 1996:14:349-354.

147. Baker KM, Booz GW. Dostal DE: Cardiac actions of angiotensin II: Role of an intracardiac renin-angiotensin system. Annu Rev Physiol 1992:54:227-241.

148. Csikos T. Chung O. Unger T: Receptors and their classification: focus on angiotensin II and the AT2 receptor. 3 Hum Hivpertens 1998: 12:311-318.

149. Nishimura H, Walker OE. Patton CM. Madison AB. Chiu AT, Keiser J: Novel angictensin receptors in the fowl. $A m . J$ Physiol 1994:267:R1174-RI 181.

150. Neuss M. Regitz-Zagrosek V. Hildebrandt A. Fleck E: Isolation and characterisation of luman cardiac fibroblasts from explanted adult hearts. Cell Tissue Res 1996:286:145153.
I5l. Mukoyama M, Nakajima M, Horiuchi M, Sasamura H, Pratı RE, Dzau VJ: Expression cloning of type 2 angiotensin II reccptor reveals a unique class of seventransmembrane receptors. $J$ Biol Chem 1993:268:24539-24542.

152. de Gasparo M, Boitari S, Levens NR: Characteristics of angiotensin II receptors and their role in cell and organ physiology, in Laragh $\mathrm{JH}$. Brenner BM (eds): Hypertension: pathophysiology, diagnosis and management. second ed. New York, Raven Press Lid., 1995. pp. 1695-1720.

153. Sadoshima J. Izumo S: Signal transduction pathways of angiotensin II--induced c-fos gene expression in cardiac myocytes in vitro. Roles of phospholipid-derived second messengers. Circ Res 1993;73:424-438.

154. Huang X-C. Richards EM, Sumners C: Mitogen-activated protein kinases in rat brain neuronal cultures are activated by angiotensin II type 1 receptors and inhibited by angiolensin II type 2 receptors. $J$ Biol Chem 1996;271:15635-15641.

155. Schmiz U, Ishida T, Surapisitchat J, Hasham MI, Peiech S. Berk BC: Angiotensin II stimulates $\mathrm{p} 2 \mathrm{l}$-activated kinase in vascular sinooth muscle cells. Circ Res 1998:82:12721278.

156. Marrero MB. Schieffer B, Paxion WG. Heerdt L. Berk BC. Delafontaine P. Bernstein KE: Direct stimulation of Jak/STAT pathway by the angiotensin II ATI receptor. Nature $1995: 375: 247-250$.

157. Sadoshima J. Qiu Z, Morgan JP. Izumo S: Angiotensin II and olher hypertrophic stimuli mediated by $G$ protein-coupled receptors activate tyrosine kinase. mitogen-activated protein kinase, and 90-kD 56 kinase in cardiac myocytes. Circ Res 1995;76:1-15.

158. Hughes AD: Molecular and cellular mechanisms of action of angiolensin II (ATI) recentors in vascular smooth muscle cells. $J$ Hum Hypertens 1998; 12:275-281. 
159. Johnson MC. Aguilera G: Angiotensin-II receptor subtypes and coupling to signaiing systems in cultured fetal fibroblasts. Endocrinology 1991:129:1266-1274.

160. Rainey WE. Byrd EW, Sinnokrot RA, Carr BR: Angiotensin-II activation of CAMP and corticosterone production in bovine adrenocortical cells: effects of nonpeptide angiotensin-II antagonists. $\mathrm{Mol}$ Cell Endocrinol 1991:81:33-41.

161. Zhang J. Pratt RE: The AT2 receptor selectively associates with Gialpha2 and Gialpha 3 in the rat fetus. $J$ Biol Chem 1996:271:15026-15033.

162. Siragy HM, Carey RM: The subtype-2 (AT2) angiotensin receptor regulates renal cyclic guanosine $3^{\prime} .5^{\prime}$-monophosphate and ATIreeptor mediated prostaglandin $\mathrm{E}_{2}$ production in conscious rats. J Clin liwest 1996:97:19781982.

163. Brechler V. Levens NR, de Gasparo $M$. Bottari SP: Angiotensin AT2 receptor mediated inhibition of particulate guanylatc cyclase: a link with protein tyrosine phosphatase stimulation? Receptors and Channels 1994:2:79-87.

164. Hayashida W. Horiuchi M. Dzau VJ: Intracellular loop domain of angiotensin II type-2 receptor. $J$ Biol Chem 1996;271:21985-21992.

165. Yamada T. Horiuchi M. Dzau VJ: Angiotensin II type 2 receptor mediates programmed cell dcath. Proc Natl Acad Sci USA 1996:93:156-160.

166. Tsuzuki S. Matoba T. Eguchi S. Inagami T: Angiotensin II type 2 receptor inhibits cell proliferation and activates tyrosine phosphatase. Hypertension 1996:28:916-918.

167. Bollari SP. King IN, Reichlin S. Dahlstroem I. Lydon N, de-Gasparo M: The angiotensin AT2 receptor stimulates protein tyrosine phosphatase activity and mediates inhibition of particulate guanylase cyclase. Biochem Biophys Res Commun 1992:183:206-211.
168. Kambayashi Y, Bardhan S, Takahashi K, Tsuzuki S, Inui $\mathrm{H}$, Hamakubo $\mathrm{T}$, inagami $\mathrm{T}$ : Molecular cloning of a novel angiotensin II receptor isoform involved in phosphotyrosine phosphate inhibition. $J$ Biol Chem 1993:268:24543-24546.

169. Booz GW. Baker KM: Role of type I and type 2 angioiensin receptors in angiotensin IIinduced cardiomyocyte hypertroply. Hypertension 1996:28:635-640.

170. Matsubara H, Kanasaki M. Murasawa S. Tsukaguchi Y. Nio Y. Inada M: Differential gene expression and regulation of angiotensin II receptor subtypes in rat cardiac fibroblasts and cardiomyocytes in culturc. $J$ Clin Invesi 1994:93:1592-1601.

171. Meggs LG. Coupet J. Huang H, Cheng W, Li P. Capasso JM. Homcy CJ, Anversa P: Regulation of angiotensin II receptors on ventricular myocytes after inyocardial infarction in rats. Circ Res 1993:72:1149. 1162.

172. Schorb W. Booz GW. Dostal DE. Conrad KM. Chang KC. Baker KM: Angiotensin II is mitogenic in neonatal rat cardiac fibroblasts. Circ Res 1993:72:1245-1254.

173. Villareal FJ. Kim NN. Ungab GD, Printz MP. Dillmann WH: Identification of functional angiotensin II receptors on rat cardiac fibroblasts. Circulation 1993:88:2849-2861.

174. Farch \}. Touyz RM, Schiftrin EL. Thibault G: Endollelin- 1 and angiotensin II receptors in cells from rat hypertrophicd licart. Circ Res 1996:78:302-311.

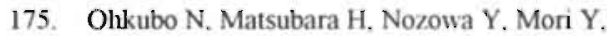
Murasawa S. Kijima K. Maruyama K. Masaki H. Tsutumi Y. Shibazaki Y. Iwasaka T', Inada $M$ : Angiotensin type 2 receptors are reexpressed by cardiac fibroblasts from failing miopathic hamster hearts and inhibit cell growth and fibrillar collagen metabolism. Circulation 1997:96:3954-3962.

176. Sun Y. Weber KT: Cells expressing angiotensin II receptors in fibrous tissue of rat 
heart. Cardiovasc Res 1996;31:518-525.

177. Walsh DA, Hu D-E, Wharion J, Catravas ID. Blake DR, Fan T-P: Sequential development of angiotensin receptors and angiotensin I converting enzyme during angiogenesis in the rat subcutaneous sponge granuloma. $\mathrm{Br} J$ Pharmacol 1997;120:1302-1311.

178. Bastien NR, Ciuffo GM, Saavedra JM, Lambert C: Angiotensin II receptor expression in the conduction system and arterial duct of neonatal and adult rat hearts. Regul Pept 1996;63:9-16.

179. Wang Z-Q, Moore AF, Ozono R, Siragy HM, Carey RM: Immunolocalization of subtype 2 angiotensin II (AT2) receptor protein in the heart. Hypertension 1998:32:78-83.

180. Stoll M. Steckelings M. Paul M, Bottari SP. Metzger R, Unger T: The angiotensin AT2receptor mediates inhibition of cell proliferation in coronary endothelial cells. $J$ Clin Invest 1995:95:651-657.

181. Allen AM. Yamada H. Mendelsohn FA: In vitro autoradiographic localization of binding to angiotensin receptors in the rat heart. $I n t J$ Cardiol 1990;28:25-33.

182. Reiss K, Capasso JM, Huang H, Meggs LG. Li P, Anversa P: Angll receptors, c-myc, and $c$-jun in myocytes after myocardial infarction and ventricular failure. Am J Physiol 1993:264:H760-H769.

183. Iwai $\mathrm{N}$, Shimoike $\mathrm{H}$, Kinoshita $\mathrm{M}$ : Cardiac renin angiolensin system in the hypertrophied heart. Circulation 1995:92:2690-2696.

184. Pieruzzi F, Abassi ZA. Keiser HR: Expression of renin angiotensin system components in the hear, kidneys, and lungs of rats with experimental heart failure. Circulation 1995;92:3105-3112.

185. Kijima K. Matsubara H. Murasawa S. Manuyama K, Mori Y. Olkubo N, Komuro I. lwasaka T, Inada M: Mechanical stretch induces enhanced expression of angiotensin II receptor subtypes in neonatal rat cardiac myo- cytes. Circ Res 1996;79:887-897.

186. Urata H, Healey B, Stewart RW, Bumpus FM. Husain A: Angiotensin II receptors in normal and failing human hearts. I Clin Endocrinol Metab 1989:69:54-66.

187. Haywood GA. Gullestad L. Katsuya T, Hutchinson HG. Pratt RE. Horiuchi M, Fowler MB: AT1 and AT2 angiotensin receplor gene expression in human heart failure. Circulation 1997:95:1201-1206.

188. Lindpaintner K. Lu W. Neidermajer N. Schicfler B. Just H. Ganten D. Drcxler H: Sclective activation of cardiac angiotensinogen gene expression in postinfarction ventricular remodeling in the rat. $J$ lul Cell c ardiol 1993:25:133-143.

189. Hirsch AT, Talsness CE. Schunker H, Paul M. D/au VJ: Tissue-specific activation of cardiac angiotensin converting ensme in experimental hear failure. ('irc Res $1091: 09+475-482$.

190. Sun Y, Weber KT: Angiotensin converting encylne and my ofibroblasts during tissue repair in the rat heart. $J .1 / 0 /\left(^{\circ} e l /\right.$ ( $^{\prime}$ ardiol 1996:28:851-8:88

191. Sun Y. Weber KT: Angiotensin Il receptor binding following myocardial infarction in the rat. Corchovasc Res 1994:28:1623-1628.

192. Sun Y, Cleutjens JPM. Diaz-Arias AA, Weber KT: Cardiac angiotensin converting enzyme and inyocardial fibrosis in the rat. Cardiovase Res 1994:28:1423-1432.

193. Everett $A D$. Fisher A. Tufro-McReddie A. Harris $M$ : Developinental regulation of angiotensin type 1 and 2 receptor gene expression and heart growth. $J \mathrm{~A} / \mathrm{O} / \mathrm{Ce} / \mathrm{l}$ Cardiol 1997:29:141-148.

194. Susic D. Nunez E, Frohlich ED. Prakash O: Angiotensin II increases left ventricular mass without affecting myosin isoform mRNAs. Hypertension 1996;28:265-268.

195. Schieffer B, Wirger A, Meybrunn M, Seiz S. Holtz. J. Ricde UN. Drexler H: Comparative 
effects of chronic angiotensin-converting enzyme inhibition and angiotensin II type 1 receptor blockade on cardiac remodeling after myocardial infarction in the rat. Circulation $1994 ; 89: 2273-2282$.

196. Wollert KC, Studer R. Doerfer K, Schieffer E. Holubarsch C. Just H. Drexler H: Differential effects of kinins on cardiomyocyte hypertrophy and interstitial collagen matrix in the surviving myocardium after myocardial infarction in the rat. Circulation 1997;95:1910-1917.

197. Duncan A-M. Burrell LM, Kladis A. Campbell DJ: Effects of angiotensinconverting enzyme inhibition on angiotensin and bradykinin peptides in rats with myocardial infarction. $J$ Cardiovasc Pharmacol 1996;28:746-754.

198. Sinits JFM. Van Krimpen C. Schoemaker RG, Cleutjens JPM. Daemen MJAP Angiotensin II receptor blockade after myocardial infarction in rats: effects on hemodyramics, myocardial DNA synthesis and interstitial collagen content. $J$ Cardiovasc Pharmasel 1942:20:772-778.

199. Childs TJ. Adams MA. Mak AS: Regression of cardiac lypertrophy in spontaneously hyperiensive rats by enalapril and the expression of contractile proteins. IT:pertension 1990:16:662-668

200. Mizuno K. Tani M. Hashimoto S. Niimura S. Sanada H. Watanabe H. Oltisuki M. Fukuchi $S$ : Effects of losartan. a nonpeptide angiotensin II receptor antagonist. on cardiac hypertrophy and the tissue angiotensin II content in spontaneously hypertensive rats. Life Sci 1992:51:367-374

201. Linz W. Henning R. Scholkens BA: Role of angiotensin II receptor antagonism and converting enzyme inhibition in the progression and regression of cardiac hypertroply in rats. J Hypertens Suppl 19)1:9:S $400-\mathrm{S}+01$

202. Everett AD. Tu厅ro-McReddie A. Fisher A. Gomez. RA: Angiotensin receptor regulates cardiac hyperirophy and transforming growth factor-beta 1 expression. Hypertension 1994:23:587-592.

203. Ruzicka M, Yuan B. Harmsen E, Leenen FH: The renin-angiotensin system and volume overload-induced cardiac hypertrophy in rats. Effects of angiotensin converting enzyme inhibitor versus angiotensin II receptor blocker. Circulation 1993;87:921-930.

204. Sadoshima J. Izumo S: Molecular characterization of angiotensin II-induced hypertrophy of cardiac myocytes and hyperplasia of cardiac fibroblasts. Critical role of the ATI receptor subtype. Circ Res 1993:73:413-423.

205. Baker KM. Accto JF: Angiotensin II stimulation of protein synthesis and cell growth in chick heart cells. Am J Physiol 1990:259:H610-H618.

206. Liu Y, Leri A. Li B, Wang X, Cheng W, Kajstura J. Anversa P: Angiotensin II stimulation in vitro induces hypertrophy of normal and postinfarcted ventricular myocytes. Circ Res 1998:82:1145-1159.

207. Regan CP. Anderson PG, Bishop SP, Berecek $\mathrm{KH}$ : Captopril prevents vascular and fibrotic changes but not cardiac hypertrophy in aorticbanded rats. Am J Physiol 1996;271:H906H913.

208. Thienelt CD. Weinberg EO. Bartunek J, Lorell BH: Load-induced growth responses in isolated adult rat hearts; role of the AT1 receptor. Circulation 1997:95:2677-2683.

209. Weinberg EO. Lee MA. Weigner M, Lindpaintner K, Bishop SP, Benedic CR, Ho KKL. Douglas PS. Chafizadeh E. Lorell BH: Angiotensin ATl receptor inhibition. Effects on hypertrophic remodeling and $A C E$ expression in rats with pressure-overload hypertroplyy due to ascending aortic stenosis. Circulation 1997:95:1592-1600

210. McDonald KM, Garr M. Carlyle PF, Francis GS, Hauer K, Hunter DW, Parish T, Stillman A. Coln JN: Relative effects of alpha 1- 
adrenoceptor blockade, converting enzyme inhibitor therapy, and angiotensin II subtype 1 receptor blockade on ventricular remodeling in the dog. Circulation 1994:90:303+-3046.

211. Wada H, Zile MR, Ivester CT, Cooper IV G, McDermott PJ: Comparative effects of contraction and angiotensin II on growth of adult feline cardiocytes in primary culture. Am J Physiol 1996:271:H29-H37.

212. Kent RL, McDcrmott PJ: Passive load and angiotensin Il evoke differential responses of gene expression and protein synthesis in cardiac myocytes. Circ Res 1996:78:829-838.

213. Sadoshima J. Izumo S: The cellular and molecular response of cardiac myocytes to mechanical stress. Anmu Rev Physiol 1997:59:551-571.

214. Poenicke K. Heinroth-Hoffmann I. Becker K. Brodde O-E: Trophic effect of angiotensin II in neonatal cardiomyocytes: role of endothelin-I and non-myocyte cells. $\mathrm{Br} J$ Pharmacol 1997;121:118-124

215. Linz W. Scholkens BA: A specific B2bradykinin receptor antagonist HOE 140 abolishes the antilypertrophic effect of ramipiil. Br.J Pharmacol 1992:105:771-772.

216. McDonald KM, Mock J, D'Aloia A, Parrish $T$. Haner K. Francis G. Stillman A. Cohn $\mathbb{N}$ Bradykinin antagonism inlibits the antigrowih effect of converting enzyme inhibition in the dog myocardium after discrete transmural myocardial necrosis. Circularion 1995:91:2043-2048.

217. Wollert KC. Drexler H: The kallikrein-kinin system in post-myocardial infarction cardiac remodeling Am $j$ Cardiol 1997:80:158A$161 \mathrm{~A}$.

2IS. Xiang J, Linz W, Becker H, Ganten D, Lang RE, Schoelkens B. Unger T: Eflects of converting enzyme inlibitors: ramipril and enalapril on peptide action and sympathetic neurotransmission in the isolated rat hear. Eur J Pharmacol 1985:113:215-223.
219. Tan LB, Jalil JE, Pick R, Janicki JS, Weber KT: Cardiac myocyte necrosis induced by angiotensin li. Circ Res 1991:69:1185-1195.

220. Sigusch HH, Campbell SE, Weber KT: Angiotensin Il-induced myocardial fibrosis in rats: role of nitric oxide, prostaglandins and bradykinin. Cardiovasc Res 1996:31:546-554

221. Ramires FJA, Sun Y, Weber KT: Myocardial fibrosis associated with aldosterone or angiotensin II administration: attenuation by calcium channel blockade. $J \mathrm{Mol}$ Cell Cardiol 1998:30:475-483.

222. Ju H. Dixon IMC: Effect of angiotensin II on Imyocardial collagen gene expression. $\mathrm{Mol}$ Cell Biochem 1996;163/164:231-237.

223. Crawford DC. Chobanian AV, Brecher P: Angiotensin Il induces fibronectin expression associated with cardiac fibrosis in the rat. Circ Res 1994;74:727-739.

224. Brilla CG. Pick R, Tan LB, Janicki JS, Weber $\mathrm{KT}$. Remodeling of the rat right and left ventrieles in experimental hypertension. Circ Res 1990;67:1355-1364.

225. Weber KT, Brilla CG: Pathological hypertrophy and cardiac interstitium. Fibrosis and renin-angiotensin-aldosterone system. Circulation 1991:83:1849-1865.

226. Weber KT. Brilla CG. Campbell SE. Guarda E. Zhou G. Sriram K: Myocardial fibrosis: role of angiotensin $\mathrm{Il}$ and aldosterone, in Grobecker.H. Heusch G, Strauer BE (eds): Angiotensin and the Heart. Supplement to Basic Research in Cardiology. Darmstadt. Sieinkopff Verlag. 1993, vol 88(Suppl.1). pp 107-12t

227. Michel JB. Lattion AL. Salzmann 几. Cerol ML. Plilippe M. Camilleri JP. Corvol P. Hormonal and cardiac effects of converting enzyme inhibition in rat myocardial infarction. Circ Rex 1988:62:641-650

228. Makino N. Matsui H. Masutomo K. Hata T. Yanaga $T$ : Effect of angiotensin converting etsyme inlibition on regression in cardiac 
hypertrophy. Mol Cell Biochem 1993:119:2328.

229. Linz W, Schaper J, Wiemer G, Albus U, Schoclkens BA: Ramipril prevents left ventricular hypertrophy with myocardial fibrosis without blood pressure reduction: a one year study in rats. Br J Pharmacol 1992; 107:970-975.

230. Jalil JE, Janicki JS, Pick R, Weber KT: Coronary vascular remodeling and myocardial fibrosis in the rat with renovascular hypertension. Response to captopril. Am J Hypertens 1991;4:51-55.

231. Brilla CG, Matsubara L, Weber KT: Advanced hypertensive heart disease in spontaneously hypertensive rats. Lisinoprilmediated regression of myocardial fibrosis. Hypertension 1996;28:269-275.

232. Brilla CG, Zhou G, Matsubara L, Weber KT: Collagen metabolism in cultured adult cardiac fibroblasts: response to angiotensin II and aldosterone. J Mol Cell Cardiol 1994;26:809820 .

233. Carver W, Nagpal ML, Nachtigal M, Borg TK, Terracio L: Collagen expression in mechanically stimulated cardiac fibroblasts. Circ Res 1991:69:116-122

234. Ratajska A. Campbell SE. Sun Y. Weber KT: Angiotensin II associated cardiac myocytc necrosis: role of adrenal catccholamines. Cardiovasc Res 1994;28:684-690.

235. Ashizawa N, Graf K, Do YS, Nunohiro T, Giachelli CM. Meehan WP. Tuan T-L. Hsueh WA: Ostcopontin is produced by rat cardiac fibroblasts and mediales AngIl-induced DNA synthesis and collagen gel contraction. $J \mathrm{Clm}$ Imest 1996;98:2218-2227.

236. Fernandez L, Twickler J, Mead A: Neovascularization produced by angiotensin II. J Lab Clin Med 1985;105:141-145.

237. Munzenmaier DH, Greene AS: Opposing actions of angiotensin II on microvascular growth and arterial blood pressure.
Hyperiension 1996;27:759-765.

238. Hu D-E, Hilley CR, Fan T-PD: Comparative studies of the angiogenic activity of vasoactive intestinal peptide, endothelins -1 and -3 and angiotensin $\mathrm{ll}$ in a rat sponge model. $\mathrm{Br} J$ Pharmacol 1996;117:545-551.

239. Le-Noble FAC, Hekiking JWM, Van-Straaten HWM, Slaaf DW, Striyker-Boudier HAJ: Angiotensin Il stimulates angiogenesis in the chorio-allantoic membrane of the chick embryo. Eur J Pharmacol 1991:195:305-306.

240. Wolf G, Ziyadeh FN, Zahner G, Staht RAK: Angiotensin II is mitogenic for cultured rat glomenular endothelial cells. Hypertension 1996:27:897-905.

241. Canby CA, Tomanek RJ: Role of lowering arterial pressure on maximal coronary flow with and without regression of cardiac hypertrophy. Am J Physiol 1989:257:H1110H1118.

242. Unger T, Mattfeidt T. Lamberty V, Bock P, Mall G, Linz W, Scholkens BA, Goh!ke P: Effect of early onset angiotensin converting enzyme inhibition on myocardial capillaries. Ilypertension 1992;20:478-482.

243. Clozel J-P. Kuhn H. Hefi F: Effects of chronic ACE inhibition on cardiac hypertrophy and coronary vascular reserve in spontaneously hypertensive rats with developed hyperiension. J Hypertens 1989;7:267-275.

244. Nelissen-Vrancken HJMG. Struyker-Boudier HAJ. Diemen MJAP. Smils JFM: Antihyperiensive therapy and adaptive mechanisms in periphenal ischemia. Flypertension 1993:22:780-788

245. Wang DH. Prewill RL: Captopril reduces aortic and microvascular growth in hypertensive and normotensive rats Hypertension !990: 15:68-77.

246. Volpert OV. Ward. WF, Lingen MW, Chesler L. Solt DB. Johnson MD, Molteni A.

Polverini PJ. Bouck NP: Captopril inlibits 
angiogenesis and slows the growth of experimental tumours in rats. J Clin Invest 1996;98:671-679.

247. Campbell DJ, Kladis A, Valentijn AJ: Effects of losartan on angiotensin and bradykinin peptides and angiotensir-converting enzyme. $J$ Cardiovasc Pharmacol 1995;26:233-240.

248. Plefler JM, Pfeffer MA, Braunwald E: Influence of chronic captopril therapy on the infarcted left ventricle of the rat. Circ Res 1985:57:84-95.

249. Sweet CS, Emmert SE, Stabilito II, Ribeiro L.G: Increased survival in rats with congestive heart failure treated with enalapril. $J$ Cardiovase Pharmacol 1987:10:634-642.

250. The Acute Infarction Ramipril Eflicacy (AIRE) Study Investigators: Effect of ramipril on mortality and morbidity of survivors of acute myocardial infarction with clinical evidence of heart failure. Lancet 1993:342:821-828.

251. Swedberg K. Held P. Kjekshus J. Rasmussen K. Ryden L. Wedel H: Effects of the early administration of enalapril on monality in patients with acute myocardial infarctionresults of the cooperative new Scandinavian enalapril survival study (CONSENSUS II). $N$ Engl J Med 1992;327:678-684.

252. Gruppo Italiano per lo Studio della Sopravivenza Nell'Iníarto Miocardico. GISSI-3: Effects of lisinopril and transdermal glyceryl trinitrate singly and together on 6 week mortality and ventricular function after acute myocardial infarction. Lances 1994:343:1115-1122.

253. Ambrosioni $\mathrm{E}$. Borghi $\mathrm{C}$, Mignnani $\mathrm{B}$, For the Survival of Myocardial Infarction Long-term Evaluation (SMILE) Study Investigators: The effect of the angiotensin-converting enzyme inhibitor zofenopril on morality and morbidity after anterior myocardial infaretion. $N$ Engl J Med 1995:332:80-85.

254. ISIS-4 (Fourth International Study of Infarct Survival) Collaborative Group. ISIS -4 : A randomised factorial trial assessing early oral captopril, oral mononitrate, and intravenous magnesium sulphate in 58,050 patients with suspected acute myocardial infarction. Lancet $1995 ; 345: 669-685$.

25.5. Franzosi MG. Santoro E. Zuanetti G, Baigent C. Yusuf S et al, ACE Inhibitor Myocardial Infarction Collaborative Group: Indications for ACE inlibitors in the early treatment of acute myocardial infarction. Circulation 1998;97:2202-2212.

256. Pfeffer MA. Greaves SC. Arnold O, Glynn $\mathrm{RJ}$, et al: Early versus delayed angiotensinconverting enzyme inhibition therapy in acute myocardial infarction. The Healing and Early Afterload Reducing Therapy Trial (HEART). Circulation 1997:95:2643-2651.

257. Pill B, Segal R, Martinez FA, Meurers G, Cowley AJ, Thomas I, Deedwania PC. Sanvely DB. Chang PI: Randomised trial of losartan versus captopril in patients over 65 with heart failure (Evaluation of Losartan in the Elderly Study, ELITE). Lancet 1997:349:747-752.

258. Rockman HA. Koch WJ. Lefkowit7. RJ Cardiac function in genetically engineered mice with altered adrenergic receptor signaling. Invited review. $1 \mathrm{~m} . / \mathrm{Ph}$ isiol 1997:272:H1553-H1559.

259. Noll G. Wenzel RR, Binggeli C. Corti C. Luescher TF: Role of sympathetic nervous system in hypertension and effects of cardiovascular drugs. Eur Heart $J$ 1998:19(Suppl.F):F32-F38.

260. Bylund DB. Eikenberg DC, Hieble JP, Langer SZ. Lefkowitz RJ. Minneman KP. Molinoff PB. Ruffolo RR. Trendelenburg U: International union of pharmacology nomenclature of adrenoceptors. Pharmacol Rev 1994:46:121-136.

261. Struyker-Boudier HA. Janssen BJ, Smits JF: Adrenoceptors in the kidney: localization and pharmacology. Clin Exp Hyperfens 1987:9(Suppl 1): 135-150. 
262. van-Klecf EM, Smits JF. De-Mey JG. Cleutjens JP, Lombardi DM, Schwartz SM. Dacmen MJ: Alpha 1-adrenoreceptor blockade reduces the angiotensin II-induced vascular smooth muscle cell DNA șmthesis in the rat thoracic aorta and carotid artery. Circ Re's 1992:70:1122-1127.

263. Van Klecf EM, Smits JFM. Schwart/ SM. Dacmen MJAP: Doxazosin blocks the angiotensin II-induced smooth muscle cell DNA synthesis in the media. but not in the neointima of the rat carotid arter after balloon injury. Cardiorase Res 1996:31:324330.

264. Lefkowitz RJ, Caron MG: Adrenergic receptors: models for the study of receptors coupled to guanine nucleotide regulatory proteins. J Biol Chem 1988:263:4993-4996.

265. Ahlquist RP: A study of the adrenergic receptors. Am J Physiol 1948; 153:586-600.

266. Ruffolo RR. Hieble JP: Alpha-adrenoceptors. Pharmacol Ther 1994:61:1-64.

267. Hieble JP, Bondinell WE, Ruffolo RR: Alphaand beta-adrenoceptors: From the gene to the clinic. 1. Molecular biology and adrenoceptor subclassification. Journal of Medicinal Chemistry 1995:38:3415-3443.

268. Endolı M. Hiramoto T, Ishihata A. Takanashi M. Inui J: Myocardial alpha 1-adrenoceptors mediate positive inotropic effect and changes in phosphatidylinositol metabolism. Species differences in receptor distribution and the intracellular coupling process in manmalian ventricular myocardium. Circ Res 1991:68:1179-1190.

269. Stcinfath M. Chen YY, Lavicky J, Magnussen O. Nose M. Rosswag S. Schmitz W. Scholz. $\mathrm{H}$ : Cardiac alphal-adrenoceptor densities in different mammalian species. Br J Phormacol 1992;107:185-188.

270. Hieble JP. Bylund DB. Clarke DE. Eikenburg DC, Langer SZ. Lefkowite RJ, Minneman KP. Ruffolo RR: International union of pharmacology X. Recommendation for nomenclature of alphal-adrenoceptors: consensus update. Pharmaco! Rev $1995 ; 47: 267-270$.

271. Graham RM, Perez DM, Hwa J, Piascik MT: A.lphal-adrenergic receptor subtypes. Circ Res 1996:78:737-749.

272. Van Zwieten PA: Alpha-adrenoceptorblocking agents in the treatment of hypertension, in Laragh JH, Brenner BM (eds): Hypertension, Pathophysiology. Diagnosis; and Management, second ed. New York, Raven Press, 1995, pp. 2917-2935.

273. Insel PA: Adrenergic receptors-evolving concepts and clinical implications. $N$ Engl J Med 1996:334:580-585.

274. Terzic A, Puceat M, Vassort G, Vogel SM: Cardiac alphal-adrenoceptors: an overvicw. Pharmacol Rev 1993;45:147-175.

275. Simpson PC, Kariya K, Karns LR. Long CS, Karliner JS: Adrenergic hormones and control of cardiac myocyie growth. Mol Cell Biochem 1991;104:35-43.

276. Milligan G. Svoboda P. Brown CM: Why are there so many adrenoceptor subtypes? Biochem Pharmacol 1994;48: 1059-1071.

277. Yamazaki T. Komuro I, Zou Y, Kudoh S, Shiojima I. Hiroi Y, Mizuno T. Aikawa R, Takano $H$, Yazaki $Y$ : Norepinephrine induces the raf-I kinascimitogen-activated protein cascade through bolh alphal - and betaadrenoceptors. Circulation 1997:95:12601268.

278. Alblas J, van Corven EJ. Hordijk PL. Milligan G. Moolenaar WH: Gi-mediated activation of the $\mathrm{p} 2 \mathrm{I}$ ras-mitogen-activated protein kinase pathway by alpha2 adrenergic receptors cxpressed in fibroblasts. $J$ Biol Chem 1993;268:22235-22238.

279. Morgan HE. Baker KM: Cardiac hypertrophy. Mechanical, neural, and endocrine dependence. Circulation 1991:83:13-25. 
280. Kuhlmann WD, Peschke P: Comparative study of procedures for histological detection of lectin binding by use of Griffonia simplicifolia agglutinin I and gastrointestinal mucosa of the rat. Histochemistry $1984 ; 81: 265-272$.

281. Purdy RE, Weber MA: Angiotensin II amplification of alpha-adrenergic vasoconstriction: role of receptor reserve. Circ Res 1988;63:748-757.

282. Cui $Y$, Shen Y-T, Kalthof B. Iwase M, Sato N, Uechi M. Vatner SF, Vatner DE: Identification and functional role of betaadrenergic receptor subtypes in primate and rodent: in vivo versus isolated myocytes. $J$ Mol Cell Cardiol 1996;28:1307-1317.

283. Cerbai E, Guerra K, Varani M, Barbieri M Borea PA. Mugelli A: Bcta-adrenoceptor subtypes in young and old rat ventricular myocytes: a combined patch-clamp and binding study. BrJ Pharmacol $1995 ; 116: 1835-18+2$

284. Schulze W, Fu MLX: Localization of alpha 1adrenoceptors in rat and human hearts by immunocytochemistry. Mol Cell Biochem 1996; 164/164:159-165.

285. Stewart AFR, Rokosh DG. Bailcy BA. Karns LR Chang KC. Long CS, Kariya K, Simpson $\mathrm{PC}$ : Cloning of the rat alphalc-adrenergic receptor from cardiac myocytes. Circ Res $1994 ; 75: 796-802$

286. Lat YH, Robinson RB. Rosen MR, Bilezikian JP: Subclassification of beta-adrenergic receptors in cullured rat cardiac myoblasts and fibroblasts. Circ Res 1980;47:41-48.

287. Long CS, Harlogensis WE, Simpson PC: bAdrenergic stimulation of cardiac nonmyocytes augments the growth-promoting activity of non-myocyle conditioned medium. $J$ Mol Cell Cardiol 1993:25:915-925.

288. Bockman CS. Jeflries WB, Abel PW: Binding and functional characierization of alpha-2 adrenergic receptor subtypes on pig vascular endothclium. J Pharmacol Exp Ther
1993:267:1126-1!33.

289. Rona G. Chappel Gi, Balasz T, Gaudry T: An infarct-like myocardial lesion and other toxic manifestations produced by isoproterenol in the rat. Arch Pathol 1959;67:443-455.

290. Kaddoura S, Firth JD, Boheler KR, Sugden PH. Poole-Wilson PA: Endothelin-1 is involved in norepinephrine-induced ventricular hypertrophy in vivo. Circulation [996; $93: 2068-2079$.

291. Zierhu W, Zimmer HG: Significance of myocardial alpha- and beta-adrenoceptors in catecholamine-induced cardiac hypertrophy. Circ Res 1989;65:1417-1425.

292. Genovese A, Chiaricilo M, Bozzaotre M. Latte S. De Alfieri W, Condorelli M: Adrenergic acitivity as a modulating factor in the genesis of myocardial hypertrophy in the rat. Exp Mol Pathol 1984:41:390-396.

293. Collins P. Billings CG. Barer GR, Daly JJ. Jolly A: Quantitation of isoprenaline-induced changes in the ventricular myocardium. Cardiowasc Res 1975:9:797-806.

294. Alderman EL, Harrison DC: Myocardial hypertrophy resulting from low dosage isoproterenol administration in rats. Proc Soc Exp Biol Med 1971:136:268-270.

295. Stanton HC. Brenner G, Mayfield ED: Studies on isoproterenol-induced cardiomegaly in rats. Am Heart $J$ 1969;77:72-80.

296. Yamori Y. Tarazi RC, Ooshima A: Effect of beta-receptor-blocking agents on cardiovascular structural changes in spontaneous and noradrenaline-induced lypertension in rats. Clin Sci 1980;59:457s460 s.

297. Benjamin IJ. Jalil JE. Tan LB. Cho K. Weber KT. Clark WA: Isoproterenol-induced myocardial fibrosis in relation to myocyte necrosis. Circ Res 1989;65:657-670.

298. Golomb E, Abassi ZA, Cuda G. Stylianou M. Panchal VR. Trachewsky D. Keiser HR: 
Angiotensin II maintains, but does not mediate, isoproterenol-induced cardiac hypertrophy in rats. Am $J$ Physiol 1994;267:H1496-H1506.

299. Brand T, Sharma HS, Schaper W: Expression of nuclear proto-oncogenes in isoproterenolinduced cardiac hypertrophy. $J \mathrm{Mol} \mathrm{Cell}$ Cardiol 1993:25:1325-1337.

300. Fishbein MC. Lei LQ, Rubin SA: Long-term propranolol administration alters myocyte and ventricular geometry in rat hearts with and without infarction. Circulation 1988;78:369375

301. Oh BH, Ono S, Gilpin E. Ross J Jr: Altered left ventricular remodeling with beta-adrenergic blockade and exercise after coronary reperfusion in rats. Circulation 1993:87:608616.

302. Oestman-Smith I: Reduction by oral propranolol treatment of left ventricular hypertroply secondary to pressure-overload in the rat. Br J Pharmacol 1995; 116:2703-2709.

303. Oestman-Smith I: Reduction of betaadrenoceptor blockade of hypoxia-induced right heart hypertrophy in the rat. $\mathrm{Br} J$ Pharmacol 1995:116:2698-2702.

304. Latini R, Masson S. Jeremic G. Luvara G. Fiordaliso F. Calvillo L. Bernasconi R. Torri M, Rondelli I, Razzelti R, Bongrani S: Comparative cflicacy of a DA2/alpha2agonist and a beta-blocker in reducing adrenergic drive and cardiac fibrosis in an experimental model of left ventricular dysfunction after coronary artery occlusion. $J$ Cardiovasc Pharmacol 1998:31:601-608.

305. Bogovevitch MA. Fuller SJ, Sugden PH: CAMP and protein synthesis in isolated adult heart preparations Aim J Phwsiol 1993:265:C1247-C1257.

306. Milano CA. Dolber PC. Rockman HA. Bond RA. Venable ME. Allen LF, Lefkowitz RJ: Myocardial expression of a constitutively active alphalB-adrenergic receptor induces cardiac hypentophy. Proc Nall Acad Sci USA

\section{4;91:10109-10113.}

30?. Meggs LG, Tillotson J, Huang H, Sonnenblick EH, Capasso JM, Anversa P: Noncoordinate regulation of alpha- 1 adrenoceptor coupling and reexpression of alpha skeletal actir in myocardial infarction-induced left ventricular failure in rats. $J$ Clin Imest 1990:86:1451-1458.

308. Simpson P. Stimulation of hypertrophy of cultured neonatal rat heart cells through an alpha 1-adrenergic receptor and induction of beating through an alpha 1 - and beta 1 adrenergic receptor interaction. Evidence for independent regulation of growth and beating. Circ Res 1985:56:884-894.

309. Meidell RS, Sen A, Henderson SA, Slahetka MF. Chien KR: Alpla 1-adrenergic stimulation of rat myocardial celís increases protein syntlicsis. Am J Physiol 1986:251:H1076-H1084.

310. Bogoyevitch MA, Andersson MB, GillespicBrown J, Clerk A, Giennon PE. Fuller SJ, Sugden PH: Adrenergic receptor stimulation of the mitogen-activated protein kinase cascade and cardiac hypertroplyy. Biochem $J$ 1996:314:115-121.

11. Schlueter K-D. Piper HM: Trophic effects of catecholamines and parathyroid hormone on adult ventricular cardiomyocyies. Am J Plysiol 1992;236:H1739:H1746

312. Zhou XJ, Schlweter K-D, Fiper HM: Hypertrophic responsiveness of beta2adrenoceptor stimulation on aduli ventricular cardiomyocytes. Aol Cell' Biochem 1996:163/164:211-216.

3i3. Ikcda U, Tsuruya Y, Yaginuma T: Alpha 1adrenergic stimulation is coupled to cardiac inyocyle hyperiroply. Am J Physiol 1991:260:H953-H956.

314. Pinson A. Schluter KD, Zhou XJ, Schwartz P. Kessler IG. Piper HM: Alpha- and Betaadrenergic stimulation of protein synthesis in cultured adult ventricular cardiomyocytes. $J$ Mol Cell Cardiol 1993:25:477-490. 
315. Chien KR, Knowlton KU, Zhu H, Chien S: Regulation of cardiac gene expression during myocardial growth and hypertrophy: molecular studies of an adaptive physiologic response. FASEB $J$ 1991:5:3037-3046.

316. Waspe LE, Ordahl CP. Simpson PC: The cardiac betia-myosin heavy chain isogene is induced selectively in alpha l-adrenergic receptor-stimulated hypertrophy of cultured rat heart myocytes. I Clin Imvest $1990 ; 85: 1206-1214$

317. Goldspink PH, Russell B: Physiological role of phosphorylation of the cyclic AMP response element binding protein in rat cardiac nuclei. Cell Tissue Res 1996:285:379385 .

318. Cooper GIV, Kent RL, Uboh CE. Thompson EW. Marino TA: Hemodynamic versus adrenergic control of riglts ventricular hypenrophy. J C'lin Lw'st 1985;75:140131414.

319. Petrie J, Ojamaa K, Hong C. Smilari T, Klein I: Effects of adrenergic agonists on the growth and gene expression of the transplanted heart. $J$ Lab Clin Med 1994:124:789-795.

320. Laks MM. Moridy F. Swan HJC: Myocardial hypertroply produced by chronic infusion of subhyperterisive doses of norepinephrine in the dog. Chest 1973:64:75-78

321. Kclm M, Schaefer S, Mingers S. Heydthausen M. Vogt M. Molz W. Strauer BE: Left ventricular mass is linked to cardiac noradrenaline in normotensive and hypertensive patients. $J$ Hypertens 1996:14:1357-1364.

322. Luther HP. Hille S. Haase H, Morano I: Influence of mechanical activity, adrenergic stimulation. and calcium on the expression of inyosin heavy chains in cultivated neonatal Cardiomyocytes. $J$ Cell Biochem 1997:64:458465 .

323. Nagano $M$, Higaki J, Nakamura $F$, Higashimori K, Nagano N. Mikami $H$, Ogihara T: Rolc of cardiac angiotensin II in isoproterenol-induced left ventricular hypertrophy. Hypertension 1992;19:708-712

324. Sasaki H. Shimizu M. Sanjo J, Kato H, Ogawa K. Mizokami T, Hannaya K. Namiki A Isogai $Y$ : Effect of captopril on isoproterenol-induced cardiac hypertrophy. $J$ Mol Cell Cardiol 1991;23(Suppl. II):S33.

325. Omura T, Kim S. Takeuchi K, Iwao H. Takeda $T$ : Transforming growth factor beta 1 and extracellular matrix gene expression in isoprenaline induced cardiac hypertrophy: effects of inhibition of the renin-angiotensin system. Cardiowasc Res 1994:28: 1835-1842.

326. Bhambi B. Eghbali M: Effect of norepinephrine on myocardial collagen gene expression and response of cardiac fibroblasts after norepinephrine treatment. $A \mathrm{~m} J$ Pathol 1991:139:1131-1141.

327. Siri FM. Smith RM: Elfects of plasma norepincphrine elevation on the licart's adaptation to chronic aortic constriction in rats. Can J Phisiol Pharmacol 1986:(14:934939.

328. Jalil JE, Janicki JS. Pick R. Abrahams C, Weber KT: Fibrosis-induced reduction of endomyocardium in the rat after isoproterenol treatment. Circ. Res 1989:65:258-264

329. Pick R. Jalil JE, Janicki JS. Weber KT: The fibrillar nature and structure of isoproterenolinduced myocardial fibrosis in the rat. $\mathrm{Am} \mathrm{J}$ Pathol 1989:134:365-371.

330. Arita M. Horinaka S, Komatsu K. Frohlich ED: Reversal of left ventricular lypertrophy with different classes of drugs causes differing ventricular biochenical changes. $J$ Hypertens 1993; 11(Suppl. 5):S354-\$355

331. Sen S, Tarazi RC. Bumpus FM: Biochemical changes associated with development and reversal of cardiac hypertrophy in spontaneously hypenensive rats. Cardiovasc Res 1976:10:254-261.

332. Sen S. Bumpus FM: Collagen synthesis in development and reversal of cardiac 
hypertroply in spontancously hypentensive rats. Am J Cordiol 1979:44:254-958.

333. Farivar RS, Craw ford DC, Chobanian AV: Brecher $P$ : Ellect ol angiotensin II blockade on the fibroprolifcrative response to phenylephrine in the rat heart. Hypertersion 1995:25:809-813.

334. Tomanek RJ, Wessel TJ. Harrison DG: Capillary growth and gcometry during longterm hypencension and myocardial hypertrophy in dogs. Am.I Phisiol 1991:261:H1011-H1018

335. Gans JH. Cater MR: Norepineplurine induced cardiac hypertroply in dogs. life. ici 1970:9:731-740.

336. Boucek RJ, Nobel NL: Histamine, norepinephrine and bradykinin stimulation of fibroblast growth and modification of serotonin response. Proc Soc Exp Biol Med 1973; 144:929-933.

337. Sherline P, Mascardo R: Catecholamines are mitogenic in 3T3 and bovine aortic endothelial cells. J Clin Invest 1984:74:483487.

338. Fisher SA, Absher M: Norepinephrine and ANG II stimulate secretion of TGF-beta by neonatal rat cardiac fibroblasts in vitro. $A \mathrm{~m} J$ Physiol 1995:268:C910-C917.

339. Torry RJ. Connell PM. O'Brien DM. Chilian WM, Tomanck RJ: Sympatheciomy stimulates capillary but not precapillary growth in hypertrophic hearts. Am J Physiol 1991:260:H1515-H1521.

340. Tomanek RJ: Sympathetic nerves modify mitochondrial and capillary growth in nonnotensive and hypertensive rats. $J$.Mol Cell Cardiol 1989:21:755-764.

341. Torry RJ, Rongish BJ. Tucker DC. Kostreva DR. Tomanck RJ: Influcnce of grafi innervation on neovascularization of embryonic heart tissuc grafted in oculo. $A m J$ Physiol 1996:270:H33-H37.
342. Hudlicka $\mathrm{O}$. What makes blood vessels grow? J Physiol (London) 1991;444:1-24.

343. Tasgal j, Vaughan Williams EM: The effect of prolonged propranolol administration on myocarcial transmural capiliary density in young rabbits. I Physiol Lond 1981;315:252367.

344. Brown MD, Hudlicka O: Capillary supply and cardiac performance in the rabbit after chronic dobutamine treatment. Cardiovasc Res 1991;25:909-915.

345. Ziada A, Hudlicka O, Tyler KR: The effect of long-term administration of alpha 1-blocker prazosin on capillary density in cardiac and skeletal muscle. Pflugers Arch 1989;415:355360 .

346. Wright AJA. Hudlicka O Capillary growth and changes in hearl performance induced by chronic bradycardial pacing in the rabbit. Circ Re's 1981:49:469-478.

347. Sexl V. Mancusi G. Baumgartner-Parzer S. Schutz W. Freissmuth M: Stimulation of human umbilical vein endothelial cell proliferation by A2:-adenosine and beta-2adrenoceptors. BrJ Pharmacol 1995:114:1577-1586.

348. Yusur S, Peto R, Lewis J. Collins R, Sleight $P$ : Beta-blockade during and after myocardial infarction: an overview of the randomised trials. Prog Cardiavasc Dis 1985:27:335-371.

349. Chadda K. Goldstcin S, Eivington R, Curb JD: Effect of propranolol after acute myocardial infarction in patients with congestive heart failure. Circulation 1986:73:503-510.

350. The Beta-Blocker Pooling Project Research Group: The Beta-Blocker Pooling Project (BPPP): subgroup findings from randomized trials in posi-infarction patients. Eur Heart $J$ 1988:9:8-16.

351. Williams JF, Bristow MR, Fowler MB, Francis GS. Garson A, Gersh BJ, Hammer DF. ot al: Guidelines for the evaluation and management of heart failure. $J \mathrm{Am} \mathrm{Coll}$ 


\section{Cardiol 1995;26:1376-1398.}

352. Waagstein F, Hjalmarson A, Varnauskas E, Wallentin I: Effect of chronic beta-adrenergic receptor blockade in congestive cardionnopathy. Br Heart J 1975;137: 1022-1036.

353. Swedberg K, Hjalmarson A, Waagstein F, Wallentin I: Prolongation of survival of congestive cardiomyopathy by beta-receptor blockade. Lancel 1979:1:1374-1376.

354. Fisher ML, Gottlieb SS, Plotnick GD, Greenberg NL, Patten RD, Bennett SK. Hamilton BP: Beneficial effects of metoprolol in heart failure associated with coronary artery disease: a randomized trial. $J \mathrm{Am}$ Coll Cardiol 1994:23:943-950.

355. Woodley SL, Gilbert EM, Anderson IL, et al: Beta-blockade with bucindolol in hear failure caused by ischemic versus idiopathic dilated cardiomyopathy. Circulation 1991:84:24262441 .

356. Bristow MR, O'Connell JB, Gilbert EM, French WJ, Leatherman G. Kantrowitz NE, Orie J, Smucker ML. Marshall G, Kelly P. Deitchman D, Anderson JL, for the Bucindolol Investigators: Dose-response of chronic beta-blocker treatment in heart failure from either idiopathic or ischemic cardiomyopathy. Circulation 1994:89: 16321642.

357. Olsen SL, Gilbert EM, Renlund DG. Taylor DO, Yanowitz FD. Bristow MR: Carvedilol improves left ventricular function and symptoms in chronic heart failure: a doubleblind randomized study. $J \mathrm{Am}$ Coll Cardiol $1995: 25: 1225-1231$.

358. Waagstein F. Bristow MR, Swedberg K. Camerini F, Fowler MB, Silver MA, Gilbert
EM, Johnson MR, Goss FG. Hjalmarson A: Beneficial effects of metoprolol in idiopathic dilated cardiomyopathy. Lancet 1993;342:1441-1446.

359. CIBIS Investigators and Committees: A randomized trial of beta-blockade in heart failure: the Cardiac Insufficiency Bisoprolol Study (CIBIS). Circulation 1994:90:17651773.

360. Fowler MB: Are all beta-adrenergic blocking drugs erzual? Amsterdam, Excerpla Medica, 1998.

361. Packer M. Bristow MR. Colnn JN. Colucci WS. Fowler MB. Gilbert EM. Shusterman NH. For the U.S. Carvedilol Heart Failure Study Group: The effect of carvedilol on morbidity and mortality in patients with chronic heart failure. $N$ Engl $J$ Mfed 1996:334:1349-1355

362. Australian-New Zealand Heart Failure Research Collaborative Group: Effects of carvedilol. a vasodilator bela-blocker, in patients with congestive heart failure duc to isclicmic henrt disease. Circulation 1995:92:212-2!8

363. Dies $F$, Krell MJ, Whitlow $P$, Liang $C$, Goldenberg I. Applefeld MM, Gilber EM: Intcrmittent dobutamine in ambulatory outpatients with chronic cardiac failure. Circulation 1986;74 (Suppl. II):II-38.

364. Packer M. Carver JR. Rodeheffer RJ. Ivanhoe RI. Dibianco R, Zeldis SM. Hendrix GH. Bommer WJ. Elkayam U, Kukin ML, Mallis Gl. Sollano JA Shannon J. Tandon PK. DeMets DL: Effect of oral milrinone on mortality in severe chronic heart failure. $N$ Engl J Med 1991:325:1468-1475. 


\section{Evaluation of vascular cell markers for paraffin embedded rat heart tissue Quantification of endothelial cell DNA synthesis}

\section{Summary}

The microvasculature of the rat heart is subject to extensive research. Since tissue morphology is superior in paraffin embedded tissue as compared to frozen sections, paraffin embedding is preferred, especially if cellular details are important, as in double staining procedures or in situ hybridization. However, a microvascular cell marker suitable for paraffin embedded rat heart tissue has not yet been described. Therefore, a qualitative study was performed using a panel of several vascular cell markers (polyclonal antibodies to von Willebrand Factor (FVIII), FVIII-Related Antigen (FVIII-RA), Angiotensin Converting Enzyme (ACE), laminin and monoclonal antibodies including rat endothelial cell antibody-I (RECA-1), MRCOX-2, CD31(JC 70A), collagen IV, and the lectin Griffonia simplicifolia I (GSI)), to evaluate their usefulness for visualization of the cardiac microvascular network in paraffin embedded rat tissue. Staining patterns of the best microvascular marker (GSI) were compared to semithin (2 $\mu \mathrm{mi})$ adjacent serial paraffin sections stained with the Jones' methenamine silver 
method. Excellent staining results were obtained with the lectin Griffonia simplicifolia $I$.

To identify DNA synthesis of endothelial cells at the microvascular level after infarction in the non-infarcted myocardium, a lectin-BrdU double staining procedure was developed, using the lectin GSI and an anti-5-bromo-2'deoxyuridine (BrdU)-antibody. Using this double staining technique, the percentage of DNA synthesizing endothelial cells was quantified in shamoperated and infarct animals. Myocardial infarction was induced by ligation of the left anterior descending coronary artery in normotensive adult male Wistar rats and animals were sacrificed $1+$ days after surgery. About one third of DNA synthesizing cells were identified as cells derived from the microvasculature in the non-infarcted part of the left ventricle, indicating increased vascular growth in the first weeks after infarction.

\section{Introduction}

Several histological techniques are available to visualize the capillaries in the heart in order to estimate tissue capillarity and microvascular growth. Often used techniques include the visualization of alkaline phosphatase activity in the capillary bed on frozen sections, direct visualization of capillaries in semi-thin sections in plastics or evaluation of the microvasculature at the ultrastuctural level ${ }^{1}$. An altcmative approach to evaluate vascular growth is quantification of endothelial cells in the S-phase of the cell cycle by visualizing endothelial cells labeling ${ }^{13}$ 'thymidine or the thymidine analogue 5-bromo-2'-deoxyuridine (BrdU) ${ }^{2}$.

Since tissue morphology is superior in paraffin embedded tissue as compared to frozen sections, paraffin embedding is preferred, especially when cellular details are important, as in double staining procedures or in situ hybridization. Although several endothelial cell markers are currently available, information on speciesand organ- specificity is fragmentary, and a specific and sensitive marker suitable to visualize the microvascular network in paraffin embedded rat heart tissue has not yet been described. Therefore, in the present qualitative study, we applied a panel of so called "vascular cell" markers to evaluate their usefulness in routinely processed paraffin embedded rat cardiac tissue.

Subsequently, we used the most suitable vascular marker (the lectin GSI) to optimize a lectin-BrdU double staining procedure in paraffin embedded rat tissue. Using this double staining teclinique the percentage of DNA synthesizing endothelial cells was quantified in sham-operated and infarct animals. 


\section{Materials and methods}

\subsection{Microvascular cell markers in paraffin embedded rat heart tissue}

All vascular cell markers were examined on frozen- and paraffin embedded rat cardiac tissue sections.

\section{- Animals}

Normotensive adult male Wistar rats (Harlan-Winkelmann, Borchen, Germany), weighing 280-320g, were used. Animals had free access to standard food (Hope Farms, type RMH-TM, Woerden, the Netherlands) and tap water, and were housed in groups of 2-4 rats. Animals were kept at a 12-hour light-dark cycle. The experimental procedures were approved by the Ethical Committee for the Use of Experimental Animals of the institution, and conform with the "Guide for the Care and the Use of Laboratory Animals" published by the US National Institute of Health (NIH Publication No. 85-23, revised 1985).

\section{- Tissue samples and tissue processing}

All animals were killed in deep ether anesthesia after arresting the heart in diastole by injecting $1-5 \mathrm{ml}$ cadmiumchloride $(0.1 \mathrm{M})$ into the intiorior caval vein and were perfused with phosphate buffered saline (PBS, pH 7.4) containingr 1 ) $.5 \mathrm{mg} / \mathrm{ml}$ nitroprusside (Hoffimann-La Roche, Mijdrecht, The Netherlands) for 5 minutes at a pressure of $100 \mathrm{mmHg}$ via a catheter placed in the abdominal aorta.

To obtain freshly frozen tissue the hearts were excised and rapidly frozen in liquid nitrogen and stored at $-80^{\circ} \mathrm{C}$. Frozen sections were cut at $6 \mu \mathrm{m}$.

To obtain tissue for paraffin embedding, the hearts were further perfusion-fixed for 10 minutes with $10 \%$ phosphate buffered formalin (1:1 diluted in PBS, pH 7.4) containing $0.5 \mathrm{mg} / \mathrm{ml}$ nitroprusside at a pressure of $100 \mathrm{mmHg}$. The hearts were removed and blotted dry. After removal of the atria and large vessels, the ventricular mass was weighed and fixed ovenight with $10 \%$ phosphate buffered formalin at room temperature. Subsequently, the hearts were cut into four $2 \mathrm{~mm}$ slices in a plane parallel to the atrioventricular groove. After dehydration and clearing, the slices were embedded in paratfin (Paraplast. Sherwood, Missouri, USA), according to routine histological procedures. Paraffin embedded sections were cut at $4 \mu \mathrm{m}$ or $2 \mu \mathrm{m}$. 


\section{- Reagents and antibodies}

- The biotinylated derivative of the Griffonia simplicifolia I (GSI) lectin, binding to microvessels in adult rodent skeletal ${ }^{3}$ and cardiac muscle ${ }^{4}$, was purchased from Signa, St. Louis, USA.

- Polyclonal rabbit anti rat antiserum against rat laminin $(57 \mathrm{E} / 6)$ located in the basement membrane ${ }^{5}$ was provided by Dr. U. Wever, The University Institute of Pathological Anatomy, Copenhagen, Denmark.

- Monoclonal antibody 1042 against human type IV collagen ${ }^{6}$ located in the basement membrane ${ }^{5}$, was purchased from Eurodiagnostics, Apeldoorn, The Netherlands.

- Monoclonal rat endothelial cell antibody-1 (RECA-1) ${ }^{7}$ was provided by Dr. A.M. Duijvestijn, Department of Immunology, University of Limburg, The Netherlands.

- Monoclonal antibody to rat thymocyte protein MRCOX $-2^{8}$, binding to endothelium", was purchased from Serotec Limited, Oxford, England.

- Polyclonal anti-human von Willebrand Factor (FVIII), which is present in endothelial cells ${ }^{5}$, was purchased from Dakopatts, Glostrup, Denmark.

- Polyclonal antibody against human Factor VIII-Related Antigen, which is a component of Factor FVIII complex, was obtained from Biogenex Laboratories, San Ramon, USA.

- Polyclonal goat anti rabbit antibody to Angiotensin Converting Enzyme $(\mathrm{ACE})^{10}$, was provided by Dr. R.L. Soffer, Department of Biochemistry, Comell University Medical College, New York, USA.

- Monoclonal anti-human endothelial cell CD31 (JC/70A $)^{1 \mathrm{I}}$ was purchased from Dakopatts, Glostrup, Denmark.

\section{- Immunohistochemical staining}

Frozen sections were either unfixed or fixed. Fixation was performed in acetone at $-20{ }^{\circ} \mathrm{C}$ or in $10 \%$ formalin at room temperature for 10 minutes. Paraffinembedded sections were dewaxed in xylene and rehydrated through gradual ethanol series.

In all sections endogenous peroxidase activity was blocked using $0.6 \% \mathrm{H}_{2} \mathrm{O}_{2}$ methanol. Then, sections were rinsed in aqua bidest for 10 minutes. In paraffin sections the influence of enzymatic digestion was examined. The sections were treated with either $0.1 \%$ pepsin (Sigma, St. Louis, USA) in $0.1 \mathrm{M} \mathrm{HCl}$ for 30 minutes at room temperature, or with $0.1 \%$ trypsin (Difco, Detroit, USA) in $0.1 \%$ $\mathrm{CaCl}_{2}$ (Merck, Darmstadt, Germany), $\mathrm{pH} 7.8$ for 20 minutes at $37^{\circ} \mathrm{C}$, or with $0.025 \%$ pronase (Boehringer, Mannheim, Gernany) in Tris $\mathrm{HCl}, \mathrm{pH} 7.6$ for 20 
minutes at $37^{\circ} \mathrm{C}$, or not treated. Enzymatic digestion was performed prior to the addition of the primary antibodies or the lectin GSI. Primary antibodies and the lectin GSI were diluted with PBS containing $1 \%(\mathrm{w} / \mathrm{v})$ bovine serum albumin (BSA, RIA grade, Sigma, USA) and 0.1\% Tween 20 (Sigma, St. Louis, USA). Serial dilutions of primary antibodies and the lectin GSI were examined. The sections were incubated with the respective primary antibodies for 1 hour. The lectin GSI was incubated for varying times (from 30 minutes to 24 hours incubation). The second layer included a biotinylated sheep anti mouse antibody (Amersham Int., Slough, UK), diluted 1:250, for monoclonal antibodies; peroxidase conjugated rabbit anti goat antibody (Dakopatts, Glostrup, Denmark), diluted 1:1000, for $\mathrm{ACE}$; biotinylated swine anti rabbit immunoglobulin (Dakopatts, Glostrup, Denmark), diluted 1:1500, for polyclonal rabbit antisera. Peroxidase conjugated biotin-avidin complex (diluted 1:100) was obtained from Vector Laboratories Inc., Burlingam, USA.

PBS washes ( $3 \times 5$ minutes) were performed between all steps and all incubations were carried out at room temperature.

Peroxidase activity was revealed by incubation of 3,3'-diaminobenzidine (Serva, Heidelberg, Germany; $0.5 \mathrm{mg} / \mathrm{ml}$ in $50 \mathrm{mM}$ Tris/HCl pH 7.6 containing $0.002 \%$ $\mathrm{H}_{2} \mathrm{O}_{2}$ and $1.0 \mathrm{mM}$ Imidazole for 5 minutes). Finally, the sections were counterstained with hematoxylin. Negative controls were made by omitting the primary antibodies/ the lectin GSI.

\section{- Comparison between adjacent semithin GSI stained and silver stained paraffin embedded tissue sections}

An alternative, though nonspecific technique visualizing capillaries that is feasible in paraffin embedded cardiac tissue ${ }^{12}$, consists of Avalone's modification of Jones' methenamine silver method for staining basement membranes ${ }^{13}$. Semithin (2 $\left.\mu \mathrm{m}\right)$ adjacent serial paraffin sections were individually processed for either the GSI binding or the silverstaining method. Staining patterns of random corresponding fields in consecutive semithin paraffin tissue sections stained with either GSI or Jones' methenamine silver method were compared at an original magnification of $400 \mathrm{x}$, in order to determine whether there were any silver stained capillaries that failed to bind GSI. 


\subsection{Quantification of DNA synthesizing endothelial cells in the non-infarcted myocardium in rat heart tissue}

\section{- Animals}

Normotensive adult male Wistar rats (Harlan-Winkelınanu, Borchen, Gerınany), weighing $280-320 \mathrm{~g}$, were used (see above).

\section{- Myocardial infarction surgery}

Myocardial infarction (MI) was induced by ligation of the left anterior descending coronary artery (LAD), according to the method of Fishbein and colleagues ${ }^{14}$, as described in detail previously ${ }^{15}$. Animals were anesthetized with sodium pentobarbital $(60 \mathrm{mg} / \mathrm{kg}$ i.p.). Intraoperatively, the animals were respirated with room air ( 60 strokes $/ \mathrm{min}$, tidal volume $3 \mathrm{ml}$ ) after the trachea was intubated. After thoracotomy in the fourth left intercostal space, the heart was exteriorized and a 6-() silk suture was looped under the LAD near the origin of the pulmonary artery. After the heart was returned to its normal position, the ligature was pulled, occluding the artery. In sham-operated animals the suture was looped through the epicardium next to the LAD. The ribs were pulled together with 3-0 silk, negative intra-thoracic pressure was restored, and the skin sutured.

\section{- Infusion of 5-bromo-2'-deoxyuridine (BrdU)}

Starting 7 days before sacrifice, 5-Bromo-2'-deoxyUridine (infusion rate 0.8 $\mathrm{mg} / \mathrm{kg} / \mathrm{day}$; BrdU, Serva, Heidelberg, Gennany), a thymidine analogue which labels DNA synthesizing cells, was given via a subcutaneously implanted osmotic minipump (Alzet 2001, Alza Corp., Palo Alto, CA, USA).

\section{- Tissue samples and tissue processing}

At day 14 the rats were killed in deep ether anesthesia and heart tissue was processed and paraffin embedded as described above. Paraffin sections were cut at $4 \mu \mathrm{m}$. The 2-week point was chosen, because interstitial cell DNA synthesis within the non-infarcted zone has been shown to peak between 7 and 14 days after infarction in the rat ${ }^{16}$.

\section{- Measurement of infarct size}

To determine infarct size, the hearts were cut into four transverse slices of $2 \mathrm{~mm}$ at four different levels (level 1 is basal level; level 4 is apical level), as described above. The correlation between the mean infarct size and the infarct size at the 
four different levels was investigated. As demonstrated in figure 1, there was a very good correlation between the mean infarct size and the infarct size at level 2 (mid-ventricular slice). Therefore, sections $(4 \mu \mathrm{m})$ from the mid-ventricular slice were stained according to the modified AZAN technique ${ }^{16}$. Infarct size was determined by computerized morphometry (Quantimet 570, Leica, The Netherlands), and expressed as a percentage of left ventricular circumference ${ }^{14,17}$.
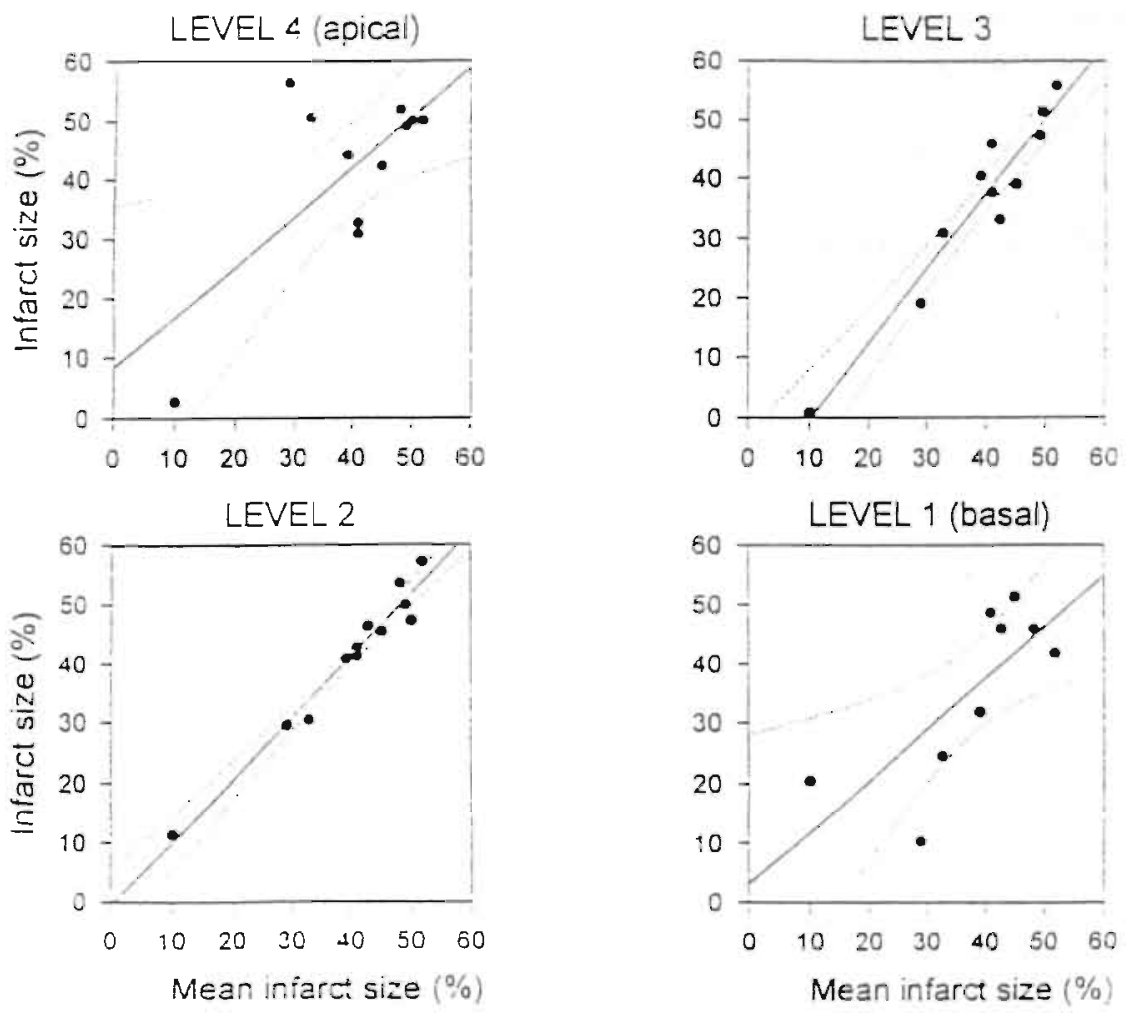

Figure 1: Correlation between mean infarct size (calculated as the mean of the infarct sizes at all levels) and infarct size at the individual levels of the heart. Level 1 is the basal level, and level $t$ is the apical level. The straight line represents the correlation between infarct size at level and mean infarct size. The dotted lines represent the $95 \%$ confidence intervals. There is a very good correlation between infarct size at level 2 (mid-ventricular slice) and mean infarcl size $\left(r^{2}=0.960\right)$. 


\section{- Single staining with anti-5-bromo-2'-deoxyuridine (anti-BrdU)}

The incorporation of $\mathrm{BrdU}$ was visualized by staining with a murine monoclonal anti-BrdU antibody ${ }^{18}$, as described previously ${ }^{16}$. Briefly, after blocking of endogenous peroxidase activity, washing in phosphate buffered saline (PBS pH $7.4,3 \times 5$ minutes) and digestion in $0.1 \mathrm{mg} / \mathrm{ml}$ pepsin (Sigma, St. Louis, USA) in $0.1 \mathrm{~N} \mathrm{HCl}\left(30\right.$ minutes $37^{\circ} \mathrm{C}$ ), the sections were incubated in $2 \mathrm{~N} \mathrm{HCl}$ (30 minutes $37^{\circ} \mathrm{C}$ ) and washed in $0.1 \mathrm{M}$ sodium tetraborate $(\mathrm{pH} 8.5)$. Incubation with a monoclonal anti-BrdU antibody was followed by incubation with peroxidase conjugated rabbit anti-mouse IgG (Dakopatts, Glostrup, Denmark), for 1 hour at room temperature. 3,3' Diaminobenzidine was used as chromogen. The sections were counterstained with hematoxylin, dehydrated through graded series of alcohols, cleared in xylene and mounted.

\section{- Double staining procedure (GSI-antiBrdU)}

To discriminate between DNA synthesizing endothelial cells and non-endothelial cells in the myocardium, transverse sections were double stained with the lectin Griffonia Simplicifolia I (GSI; Sigma, St. Louis, USA) and the monoclonal antiBrdU antibody (Eurodiagnostics, Apeldoorn, the Netherlands). Therefore, $4 \mu \mathrm{m}$ sections were dewaxed and rehydrated, and endogenous peroxidase was inlibited by methanol $/ \mathrm{H}_{2} \mathrm{O}_{2}(0.3 \%)$ for 15 minutes. The sections were incubated overnight with the biotinylated lectin GSI $(1: 100)$ at room temperature, followed by incubation with an alkaline phosphatase conjugated biotine-avidine complex (1:200; Dakopatts, Glostrup, Denmark) for 30 minutes at room temperature and development with Fast Blue BB' (Sigma, St. Louis, USA). The second staining step involved incubation with an anti-BrdU antibody ${ }^{18}$ (see above). The slides were coverslipped using an aqueous medium. Negative controls were made by omitting the primary antibodies/ the lectin GSI.

\section{- Measurements of total and endothelial cell DNA synthesis}

The percentage of all DNA synthesizing cells was detennined in hearts of shamoperated and infarcted rats ( $n=14 ; n=15$, respectively). The percentage of DNA synthesizing endothelial cells was also detennined. Counting was performed microscopically in the septal region of the left ventricle with an eyepiece grid ( $400 \times$ magnification), as described previously ${ }^{16}$. Measurements were performed by two investigators (MD, MK). Intra- and inter-observer variations were less than 10\%. Tissue areas containing larger arterioles and venules were excluded from counting. DNA synthesizing endothelial cells were identified based on the co-localization of both BrdU positive nuclei and GSI stained microvascular 
profiles. Since identification of both structures is best appreciated in transicrsely cut capillaries, counting was performed in the subendocardial region of the left ventricle.

For the single BrdU staining a total of $\sim 900-1300$ cells per heart were counted, whereas for the double staining at least $500 \mathrm{BrdU}$ positive nuclei were counted. The percentage of BrdU positive nuclei was calculated from the number of $\mathrm{BrdU}$ positive nuclei and the total number of nuclei. The percentage of BrdU positive endothelial nuclei was calculated from the number of BrdU positive endothelial nuclei and the total number of $\mathrm{BrdU}$ positive nuclei.

\section{- Data analysis}

Only hearts with infarct sizes larger than $21 \%$ were used in the MI group, since smaller infarcts do not have detectable hemodynamic consequences in vivo ${ }^{14}$. Data from experiments were compared by one-way analysis of variance followed by a post-hoc test (Bonferroni procedure) ${ }^{2 i}$. Data were expressed as mean \pm SEM. Differences were regarded to be statistically significant at a value of $\mathrm{P}<0.05$.

\section{Results}

\subsection{Microvascular cell markers in paraffin embedded rat heart tissue}

The staining results of the different antibodies and the GSI lectin on cryostat and paraffin embedded tissue sections are listed in table 1 and illustrated in figures 2 to 9

In general, formalin fixation yielded the best staining results on frozen sections. Antibodies reactive with laminin and collagen IV showed positive staining in large and small vessels including capillaries, on both frozen and paraffin sections. However, precise identification of vascular structures was hampered, because of cross-reactivity with the basal lamina of myocytes (figures 2 and 3 ).

RECA-1, a pan-endothelial cell-specific monoclonal antibody in the rat, showed good staining with endothelium of small and large vessels on frozen sections (figure 4), as previously described by Duijvestijn? Immunoreactivity in paraflin tissue sections was absent, with or without enzymatic pretreatment. In comparison with RECA-1, the monoclonal antibody MRCOX-2 displayed a virtually similar staining pattern (figure 5), and was also positive on frozen sections only. 

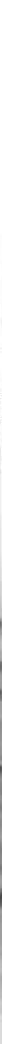

Figures 2 and 3 (upper left and right figures): Immunohistochemical staining of laminin (2) and collagen IV (3) im paraffin embedded tissue. Origimal magnification $250 x$.

Figures 4 and 5 (lower left and right figures): Immmohistochemical staiming of RECA-1 (4) and MRCOX-2 (5) in frozen fissue. Original magnification $400 x$. 

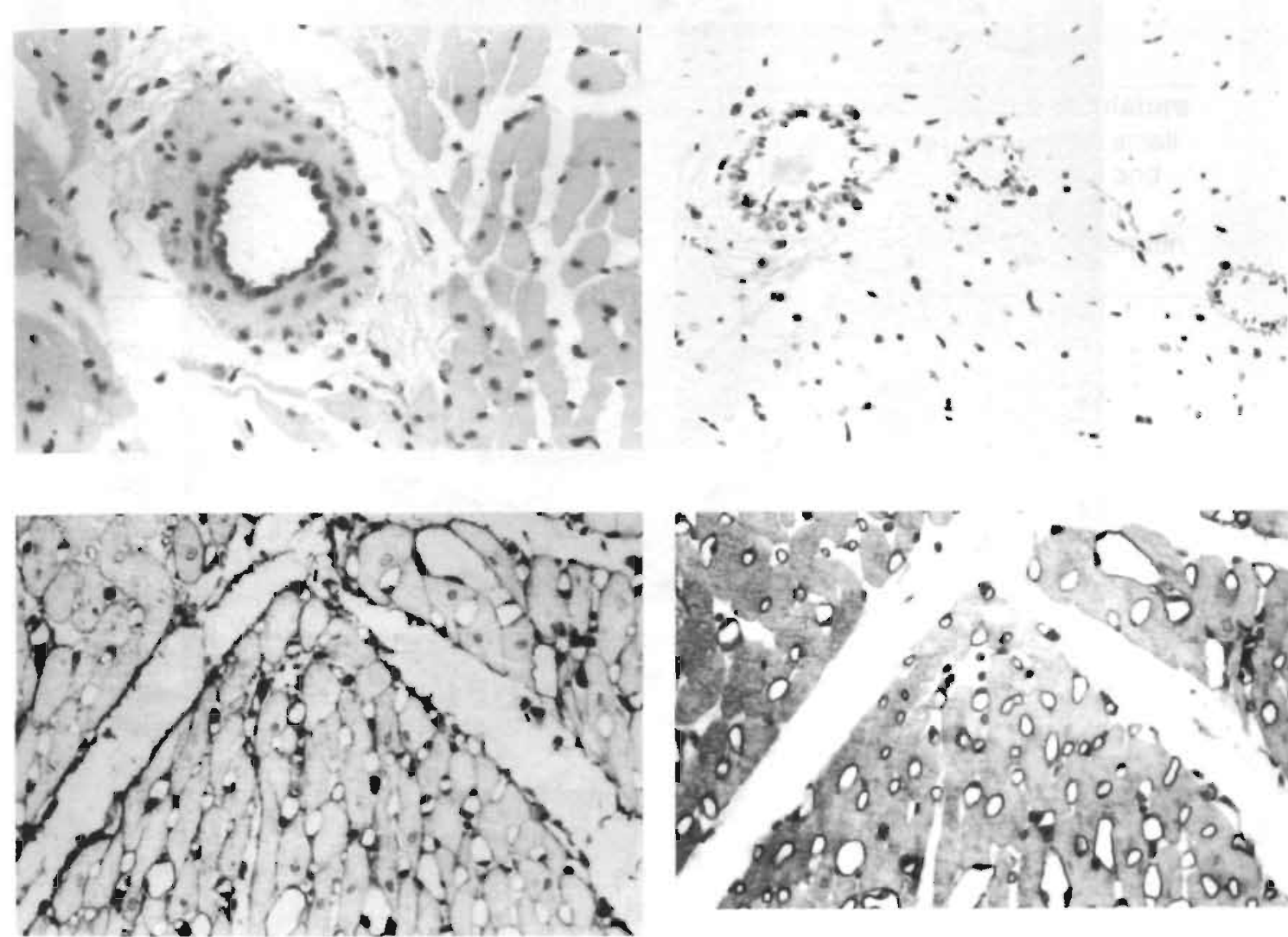

Figures 6 and 7 (upper left and right figures): Immmohistochemical staining of FVIII (6) and $A C E$ (7) in paraffin embedded issue. Original magnification $250 x$.

Figures 8 and 9 (lower left and right figures): Histochemical staining with Jones' methenamine silver in paraffin embedded tissue (8) and in adjacent semithin paraffin embedded tissue stained with the lectin GSI (9). Original magnification $400 x$. 

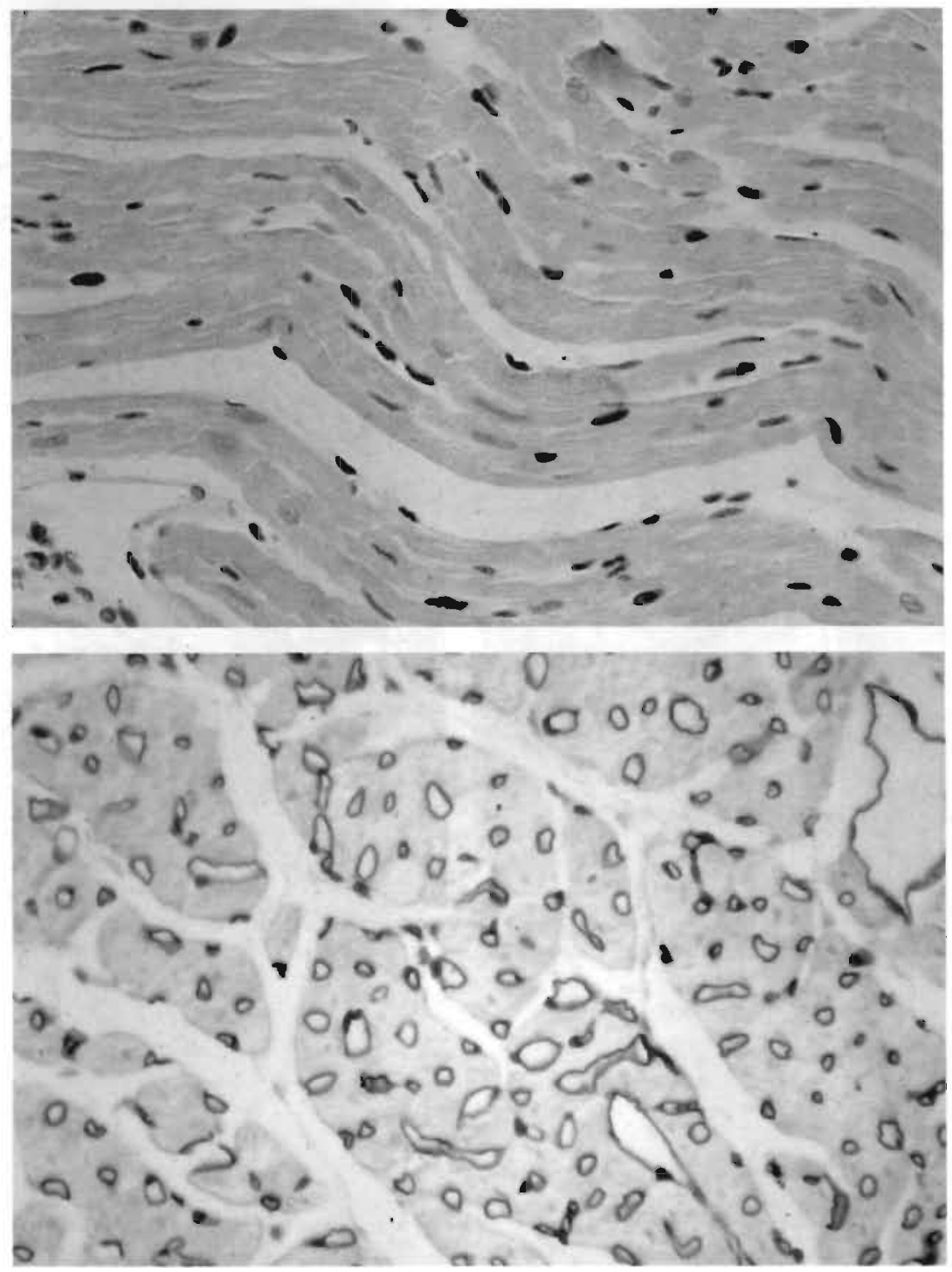

Figure 10 (upper figure): Heart section stained with the monochonal anti-Brdl : antibody and hematoxylin. Original magnification $400 x$.

Figure 11 (lower figure): Representative picture of a heart section dowble-stained with the lectin Griffonia Simplicifolia I (GSl) and the monoclonal anti-BrdU antibody. Brown colored dots: BrdU positive nuclei; blue colored lines: endothelial cells. Original magnification 400x. 
Table 1: Staining resulls of various vascular markers in rat heart tissue.

\begin{tabular}{|c|c|c|c|c|}
\hline \multirow[t]{2}{*}{ Marker } & \multicolumn{2}{|c|}{$\begin{array}{l}\text { Large vessels } \\
\text { arteries and venes }\end{array}$} & \multicolumn{2}{|c|}{$\begin{array}{l}\text { Microvasculature } \\
\text { capillaries, small } \\
\text { arterioles and } \\
\text { venules }\end{array}$} \\
\hline & Frozen & Paraffin & Frozen & Paraffin \\
\hline Polyclonal antiserum to rat laminin & + & + & + & + \\
\hline $\begin{array}{l}\text { Monoclonal antibody to human collagen } \\
\text { type IV }\end{array}$ & + & + & + & + \\
\hline $\begin{array}{l}\text { Monoclonal rat endothelial cell antibody-1 } \\
\text { (RECA-1) }\end{array}$ & + & - & + & - \\
\hline $\begin{array}{l}\text { Monoclonal antibody to rat thymocyte } \\
\text { glycoprotein (MRCOX-2) }\end{array}$ & + & - & + & - \\
\hline $\begin{array}{l}\text { Polyclonal anti human von Willebrand } \\
\text { Factor (FVIII) }\end{array}$ & + & + & \pm & \pm \\
\hline $\begin{array}{l}\text { Polyclonal antibody to human Factor VIII- } \\
\text { related antigen (FVIII-RA) }\end{array}$ & + & + & \pm & \pm \\
\hline $\begin{array}{l}\text { Polyclonal anti rabbit Angiotensin } \\
\text { Converting Enzyme (ACE) }\end{array}$ & + & + & \pm & \pm \\
\hline $\begin{array}{l}\text { Monoclonal antibody to human endothelial } \\
\text { cell CD31/ JC70A }\end{array}$ & - & - & - & - \\
\hline Lectin Griffonia Simplicifolia I (GSI) & - & - & + & + \\
\hline
\end{tabular}

$$
\begin{aligned}
& +=\text { distinct bright staining } \\
& \pm=\text { weak staining } \\
& -\quad=\text { no staining }
\end{aligned}
$$

The antibodies against von Willebrand Factor, Factor-VIII related antigen and ACE gave essentially similar results with a distinct reaction in larger vessels on frozen and paraffin tissue sections. but almost completely failed to detect capillaries (figures 6 and 7). The monoclonal anti-CD31 antibody did not reveal any staining reactivity.

Only the lectin GSI selectively bound to the microvasculature on both cryostat and paraffin embedded tissue sections. In addition to capillaries, venules and arterioles were also stained. The endothelial lining of large veins and arteries did not stain. Immunoreactivity was also present, though less intense, in vascular smooth muscle layers and in the cytoplasm of some scattered interstitial cells, 
presumably macrophages ${ }^{21}$. The binding pattern to vascular linings was identical on formalin-fixed paraffin sections and frozen sections. Staining experiments with different incubation times and GSI lectin dilutions on paraffin tissue sections showed that the best staining results with GSI were obtained at a dilution of 1:100 and by overnight incubation ( $16 \mathrm{~h})$ at room temperature. Our own and previous experiments $^{22}$ have demonstrated that such prolonged incubation times markedly increase the sensitivity of GSI lectin stainings. Pretreatment with digestive enzymes appeared not to be necessary, but rather induced background staining. In frozen sections the best results were obtained with a 75 minutes incubation time of the lectin GSI at a 1:50 dilution.

The lectin GSI sensitively revealed capillaries and terminal microvascular elements (small venules and small arterioles). Staining patterns of the microvasculature in consecutive paraffin tissue sections stained by the Jones' methenamine silver method or with the lectin GSI were completely comparable (figures 8 and 9). In the nonspecific silver method, myocyte basement membranes were also stained.

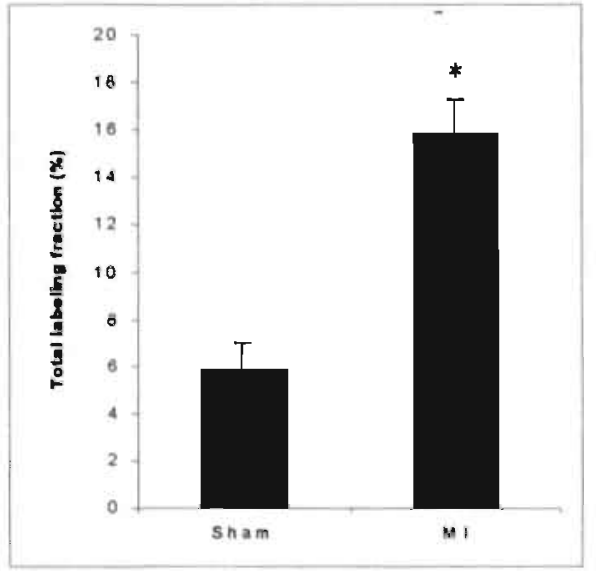

Figure 12: Total BralU labeling fraction in sham-operated (Sham) and infarcted (MI) hearts. * $P<0.05$ compared to sham-operated hearts. Dafa are expressed as mean \pm SFM.

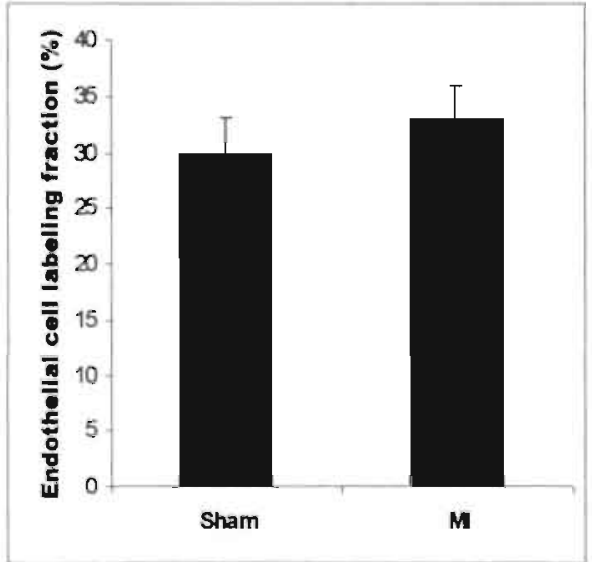

Figure 13: The percentage of BrdU labeled endothelial cells of the tolal labeling fraction in sham-operated (Sham) and infarcted (MI) hearts.

* $P<0.05$ compared to sham-operated hearts. Data are expressed as mean \pm SEM 


\subsection{Quantification of DNA synthesizing endothelial cells in the non-infarcted myocardium in rat heart tissue}

Examples of cardiac tissue sections stained with the monoclonal anti-BrdU antibody and with the double-staining GSI-BrdU technique are depicted in figures 10 and 11 , respectively.

The total labeling fraction of DNA synthesizing cells in sham-operated hearts was $5.9 \pm 1.1 \%$ (figure 12 ). Of these cells $30 \pm 3 \%$ were identified as endothelial cells (figure 13). Induction of MI significantly increased the total DNA synthesizing cell fraction at day 14 after surgery (15.9 $\pm 1.4 \%$; figure 12$)$. The proportion of endothelial cells of this population was comparable to that in sham-operated hearts ( $33 \pm 3 \%$; figure 13 ).

\section{Discussion}

The purpose of these studies was two-fold. One aim was to find and validate a reliable endothelial cell marker to quantify the capillary network in paraffin embedded rat heart tissue. Second, by using the most suitable endothelial marker (the lectin GSI) together wilh an anti-BrdU antibody, the percentage of BrdUincorporating endothelial cells in the non-infarcted myocardium was determined.

\subsection{Microvascular cell markers in paraffin embedded rat heart tissue}

A large variety ofantibodies to endothelial cell specific antigens is available, but positive immunohistochemical staining is frequently lost after paraffin embedding. Also in our panel, two monoclonal antibodies RECA-1 and MRCOX-2 distinctly stained rat cardiac endothelium including the capillary network, but only on frozen sections. In contrast, the recently described monoclonal antibody to human endothelium CD31, was shown to be suitable for routinely processed tissue in a wide range of human tissues, including the myocardium ${ }^{\prime \prime}$. The negative staining results in our study with this antibody in the rat heart probably reflects species specificity. The polyclonal antibodies to von Willebrand Factor and to Factor VIII related antigen, which are commonly used for identifying rat endothelial cells $^{2.3}$, as well as the polyclonal antibody to angiotensin converting enzyme ( $\mathrm{ACE}$ ), only faintly and partially visualized the microvascular cells in paraffin embedded tissue. 
The best results on paraffin embedded sections were obtained with the lectin Griffonia simplicifolia I (GSI). This lectin, also known as Bandeiraea simplicifolia $\mathrm{I}$, specifically binds $\mathrm{N}$-acetyl-D-galactosamine and D-galactose residues ${ }^{24}$, which appeared resistant to formalin fixation and paraffin embedding. Affinity of the lectin GSI to capillaries was first described in mouse tissues ${ }^{25}$. Ultrastructurally, GSI labeling in the rat myocardium was associated with the plasmalemma proper in the microvascular beds ${ }^{4}$. It was shown that GSI labeled endothelium of the entire microvasculature in the myocardium in frozen sections ${ }^{4}$, but there were no data on cardiac paraffin embedded tissue. In the present studies the simple GSI staining method yielded excellent results, and comparisons between GSI staining to the silver staining method indicate that the lectin GSI is a sensitive and specific marker for detecting the microvasculature in cardiac tissue following paraffin embedding. In addition, it has been reported that GSI lectin staining is stable during hypoxia ${ }^{21}$. The GSI staining pattern was more or less complementary to that of the anti-Factor VIII and anti-ACE antibodies

\subsection{Quantification of DNA synthesizing endothelial cells in the non-infarcted myocardium in rat heart tissue}

Previously, it has been shown that enhanced post-infarction DNA synthesis is a transient event, occurring in the first 2 weeks after induction of a myocardial infarction in the rat. DNA synthesis was mainly (for $\sim 98 \%$ ) confined to nonmyocytes (i.e. interstitial cells) ${ }^{16}$. Similar findings have been obtained by Taylor et al. ${ }^{27}$, who slowed the development of significant non-myocyte cellular proliferation in the non-infarct zone in rats by immunohistochemical staining of proliferating cell nuclear antigen (PCNA). The observation in the present study that total interstitial cell DNA synthesis increases in the non-infarcted myocardium confirms earlier observations ${ }^{16}$, although the absolute numbers of BrdU labeling cells are somewhat lower than in that study. Myocardial cells in the interstitium comprise predominantly fibroblasts and endothelial cells ${ }^{28}$. To further identify the phenotype of the interstitial cells participating in the increased post-infarction DNA synthesis, the above described double staining technique with the specific endothelial cell marker GSI was used. In this way, a substantial proportion of interstitial cell DNA synthesis was shown to occur in microvascular endothelial cells, likely reflecting enhanced growth of the microvasculature after infarction. On the other hand, morphometric studies have shown that numerical capillary density decreases in the non-infarcted myocardium in a young rat myocardial infarction model ${ }^{29}$. This apparent paradox can be explained by a 
relative but not absolute decline in capillarity. In other words, capillary growth does not keep pace with myocyte hypertrophy, but the reduction of capillary density by no means excludes the possibility of capillary endothelial cell proliferation. Though cardiac angiogenesis has been considered to be a rare event in adult mammals at physiological conditions, the present results and observations from other laboratories ${ }^{30-33}$ indicate that capillaries do retain their capacity to proliferate in various forms of cardiac hypertrophy.

In sham animals, positive endothelial BrdU-labeling was present as well, although to a lesser extent. The unstimulated basic DNA synthesis may reflect physiological growth ${ }^{34}$, since relatively young animals of approximately 3 months of age were used in our experiments.

In conclusion, of all vascular cell markers tested in the present studies, the lectin GSI was found to be the best marker to visualize microvascular elements in the paraffin embedded rat heart, and was found to be suitable for the development of a double staining procedure with the monoclonal antibody anti-BrdU. Results from the double staining GSI-BrdU procedure in infarcted animals show that the microvasculature in the non-infarcted myocardium substantially contributes to the enhanced DNA synthesis, indicating enhanced vascular outgrowth early after infarction. Furthermore, the double staining GSI-BrdU technique can be an useful tool to evaluate the effects of pharmacological interventions on microvascular growth after myocardial infarction in the rat heart. 


\section{References}

1. Hudlicka O: What makes blood vessels grow? I Physiol (London) 1991;444:1-24.

2. Ware JA, Simons M: Angiogenesis in ischemic heart discase. Nature Medicine 1997:3:158-164.

3. Hansen-Smith FM, Watson L, Lu DY, Goldstein I: Griffonia simplicifolia I: fluorescent tracer for microcirculatory vessels in nonperfused thin muscles and sectioned muscle. Mifrovasc Res 1988:36:199-2'15.

4. Porter GA. Palade GE, Milici AJ: Differential biriding of the lectins Griffonia simplicifolia I and Lycopersicon esculentum to microvascular endothelium: organ-specific localization and partial glycoprotein characterization. Eur I Cell Biol 1990;51:85-95.

5. Jaffe EA: Cell biology of endothelial cells. Hum Pathol 1987:18:234-239.

6. Havenith MG. Cleutjens JPM. Beek C. Van der Linden E. De Goey A.FPM. Bosman FT: Human specific anti-1ype IV monoclonal antibodies, characterization and immunolistochemical application. Histochemistry 1987:87: 123-128.

7. Duijvestijn AM. van-Goor $H$. Klatter $F$. Majoor GD, van-Bussel E, van-BredaVriesman PJ: Antibodies defining rat endothelial cells: RECA.-1. a pan-endothelial ccll-specific monoclonal antibody. Lab Invest 1992,66: 459-466.

8. McMaster WR. Williams AF: Identification of la glycoproteins in ral thymus and purification from rat spleen. Eur J Immunol $1979: 9: 426-433$.

9. Barclay AN: Different reticular elements in rat Jymphoid tissue identified by localization of la. Thy -1 and MRC OX 2 antigens. Sommanology $1981: 44727-736$.

10. Conroy JM. Hoffman H. Kirk ES, Hirzel HO Sonnenblick EH. Soffer RL: Pulmonary angiotensin-comerting enzyme. Interspecies homology and inhibition by heterologous antibody in vivo. $I \mathrm{Biol}$ Chem 1976:251:4828-4832.

11. Parums DV. Cordell JL, Micklem K, Heryet AR, Gatter K.C. Mason DY: JC70: a new monoclonal antibody that detects vascular endothelium associated antigen on routinely processed tissue sections. $J$ Clin Pathol 1990:43:752-757.

12. Yarom R. Zirkin H. Stammler G, Rose AG: Human coronary microvessels in diabetes and ischaemia. Morphometric study of autopsy material. J Pathol 1992:166:265-270.

13. Luna LG: Methods for connective tissue. in Luna LG (ed): Momal of histologic staining methods of the Armed Forces Institute of Pathology. New York. McGraw-Hill Book Company, 1968. pp. 97-99.

14. Fishbein MC. Maclean D. Maroko PR: Experimental myocardial infarction in the rat Am J Pathol 1978:90:57-70

15. Schoemaker R.G. Urquhart J. Debets JJ. Struyker-Boudicr HA. Smits JF: Acute hemody namic effects of coronary artery ligation in conscious rats. Basic Res Cardiol 1990:85:9-20.

16. Van-Krimpen C. Smits JF, Clcutjens JP, Debets JJ. Schoemaker R.G. Struyker-Boudier HA. Bosman FT. Dacmen MJ: DNA synthesis in the non-infarcted cardiac interstitium after left coronary artery ligation in the rat: effects of captopril $J$ thol Cell Cardiol $1991: 23: 1245-1253$

17. Passier RCII. Smits JFM, Verluyten MJA, Studer R:. Drexler H. Daemen MJAP: Activation of angiotensin-converting-enzyme expression in the infaret zone following myocardial infarction. A $\mathrm{m} . J$ Phusiof 1995:269:H1268-H1276.

18. Schutte B. Reynders MM, Bosman FT, Blijham GH: Studies with anti-bromodeoxyuridine antibodies: II. Simultaneous 
immunocytochemical detection of antigen expression and DNA synthesis by in vivo labeling of mouse intestinal mucosa. $J$ Histochem Cytochem 1987:35:371-374.

19. Schoemaker RG. Debets JJ, Struyker-Boudier HA, Smits JF: Delayed but not immediate captopril therapy improves cardiac function in conscious rats following myocardial infarction. J Mol Cell Cardiol 1991;23:187197.

20. Wallenstein S, Zucker CL, Fleiss JL: Some statistical methods useful in circulation research. Circ Res 1980;47:1-9.

21. Maddox DE, Shibata S, Goldstein IJ: Stimulated macrophages express a new glycoprotein receptor reactive with Griffonia simplicifolia I-B4 isolectin. Proc Natl Acad Sci USA 1982;79:166-170.

22. Kuhlmann WD, Pesclke P: Comparative study of procedures for histological detection of lectin binding by use of Griffonia simplicifolia agglutinin I and gastrointestinal mucosa of the rat. Histochemistry 1984:81:265-272.

23. Nishida M, Carley WW. Gerritsen ME, Ellingsen O, Kelly RA, Smith TW: Isolation and characterization of human and rat cardiac microvascular endothelial cells. Am J Phusiol 1993:264:H639-H652.

24. Murply LA, Goldstein IJ: Five alpla-Dgalactopyranosyl-binding isolectins from Bandeiraea simplicifolia seeds. $J$ Biol Chem 1977:252:4739-4742.

25. Laitinen L: Griffonia simplicifolia lectins bind specifically to endothelial cells and some epithelial cells in mouse tissues. Histochem $J$ $1987 ; 19: 225-234$.

26. Christie KN. Thomson C: Bandeiraea simplicifolia lectin demonstrates significantly more capillaries in rat skeletel muscie than enzyme methods. $J$ Histochem Cytochem 1989;37:1303-1304.

27. Taylor K, Patten RD, Smith JJ, Aronovitz MJ, Wight J, Salomon RN, Konstam MA: Divergent effects of angiotensin-converting enzyme inhibition and angiotensin II-receñtor antagonism on myocardial cellular proliferation and collagen deposition after: myocardial infarction in rats. $J$ Cardiovasc Pharmacol 1998;31:654-660.

28. Weber KT, Brilla CG: Pathological hypertrophy and cardiac interstitium. Fibrosis and renin-angiotensin-aldosterone system. Circulation 1991:83: 1849-1865.

29. Anversa P, Beghi C, Kikkawa Y. Olivetti G: Myocardial infarction in rats. Infarct size, myocyte hypertrophy and capillary growth. Circ Res 1986;58:26-37.

30. Tomanek RJ, Hovanec JM: The effects of long-term pressure-overload and aging on the myocardium. JMol Cell Cardiol 1981:13:471-488.

31. Olivetti G. Lagrasta $C$, Ricci R. Sonnenblick EH. Capasso JM. Anversa P: Long-teren pressure-induced cardiac hypertrophy: capillary and mast cell proliferation. $A \mathrm{~m} \mathrm{~J}$ Physial 1989:257:H1766-H1772.

32. Anversa P. Capasso JM: Loss of intermediatesized coronary arteries and capillary proliferation after left ventricular failure in rats. Am J Physiol 1991:260:H1552-H1560.

33. Tornanck RJ, Wessel TJ, Harrison DG:

Capillary growth and geometry during longterm hypenension and myocardial hypertrophy in dogs. Am J Phusiol 1991:261:H1011-H1018

34. Klinge O. Stocker E: Die DNA-Synthese im Rattenherzen als Funktion des Lebensalters. Autoradiographische Untersuchungen mit 3H-Thymidin. Experientia 1968;24:167-168. 



\section{Early captopril treatment inhibits DNA synthesis in endothelial cells and normalization of maximal coronary flow in infarcted rat hearts}

\section{Summary}

Objectives: Cardiac remodeling due to myocardial infarction (MI) includes myocyte hypertrophy, collagen deposition, a rise in DNA synthesis, and normalization of initially diminished maximal coronary bloodflow. Previously, it was demonstrated that early captopril treatment can prevent the rise in total DNA synthesis, collagen deposition and hypertrophy. In the present experiments, we investigated the effects of captopril or perindoprilat treatment on cardiac endothelial cell proliferation and maximal coronary flow.

Methods: MI was induced by ligation of the left coronary artery in Wistar rats. Sham-operated and infarcted rats were treated with captopril (12 $\mathrm{mg} / \mathrm{kg} . \mathrm{d}$ s.c.) from either day 0-21 (early) or day 21-35 (late) after surgery. In isolated. retrogradely perfused rat hearts, maximal coronary flow was determined following maximal dilatation with nitroprusside and adenosine (ImM each). In separate groups, sections of hearts of sham-operated and MI rats treated with BrdU (day 7-14) and either captopril or perindoprilat (1 mg kg.d s.c.; day 0-14) were double stained with a monoclonal anti-BrdU antibody and the lectin GSI. 
The total fraction of DNA synthesizing cells and its proportion of endothelial cells was determined.

Results: Maximal coronary flow was completely normalized in MI hearls within three weeks after surgery. Early captopril, but not late captopril, inhibited the normalization of maximal coronary flow in MI hearts (Early: sham, 27.4 1.0; MI, 21.2 $\pm 1.4 \mathrm{ml} / \mathrm{min} ; P<0.05$; mean $\pm S E M$ ) without affecting the hypertrophic response. The total fraction of DNA synthesizing cells was significantly

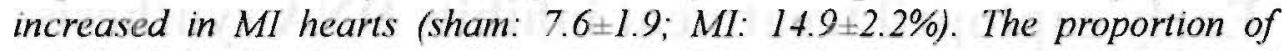
endothelial cells, however, was comparable in sham-operated and infarcted hearts (sham: $30 \pm 3 ;$ MI: $33 \pm 3 \%$ ). Both early captopril and perindoprilat treatment inhibited total DNA synthesis in MI hearts. Only in captopril treated hearts, this inhibition was associated with a disproportionate inhibition of the endothelial cell proliferation (10.3 $\pm 2.0 \%)$.

Conclusion: Early captopril treatment inhibits endothelial cell proliferation and coronary vessel growth following $M I$, which seems to be partly due to inhibition of the renin-angiotensin system.

\section{Introduction}

Induction of myocardial infarction (MI) induces remodeling of both the infarcted and the non-infarcted regions of the heart ${ }^{\prime}$. Structural remodeling in the infarcted part results predominantly in dilatation, scarring, and thinning of the infarcted tissue, whereas remodeling of the non-infarcted part of the ventricles includes hypertrophy of the myocytes, and an increase in collagen content ${ }^{1-4}$. These changes in the non-infarcted part are associated with an early increase in DNA synthesis ${ }^{3}$, which is predominantly localized in fibroblasts and endothelial cells (chapter 2). Furthermore, total maximal coronary flow normalizes within 5 weeks after MI due to a combination of recruitment of pre-existing coronary vessels and growth of new vessels 5 .

The cardiac renin-angiotensin system (RAS) plays an important role in the remodeling processes of the heart. With respect to angiotensin converting enzyme (ACE), both increased activity and mRNA expression were observed in rat hearts with pressure overload-induced hypertrophy ${ }^{6}$, in the right ventricle and the septum of infarcted rat hearts ${ }^{7}$, and in the left ventricle of failing human hearts ${ }^{8}$. Similarly, an increase in mRNA expression in the infarcted rat heart was observed ${ }^{9}$. 
Late captopril treatment (week 3-5 following MI) significantly improved cardiac function $^{10.11}$, and increased the 1 year survival rate of MI rats ${ }^{12}$. It had no effect on cardiac collagen deposition and DNA synthesis ${ }^{3}$. In contrast, early captopril treatment (week 0-3 following MI) worsened cardiac function in MI rats ${ }^{10}$. This negative effect on cardiac function was associated with inhibition of the rise in total DNA synthesis and collagen deposition ${ }^{3}$. It is, however, not known whether captopril treatment also affects the previously observed normalization of maximal coronary flow, which is due to a combination of recruitment of pre-existing coronary vessels and growth of new vessels ${ }^{5}$. To investigate the effect of captopril treatment on coronary vessel growth in infarcted hearts, both endothelial cell DNA synthesis, as an index for vessel growth, and maximal coronary flow were quantified in sham-operated and infarcted hearts following early captopril treatment. Endothelial cell proliferation was measured at day 14, because DNA synthesis is maximal between day 7 and 14 and returns to baseline within 3 weeks ${ }^{3}$. Because the outcome of the proliferative response (vessel growth) should be expected to be complete at 3 weeks after MI, which agrees with our observations $^{5}$, the effect of captopril treatment on this normalization was investigated at day 21 . In addition, maximal coronary flow was investigated in sham-operated and infarcted hearts following late captopril treatment (day 21-35). To evaluate the ACE specificity of the captopril effects, also total proliferation and endothelial cell proliferation were investigated following early perindoprilat treatment.

\section{Materials and methods}

\section{- Animals}

Male Wistar rats (Harlan-Winkelmann, Borchen, Germany), weighing 280-320 g, were used. Animals had free access to standard food (Hope Farms, Woerden, the Netherlands) and tap water, and were housed in groups of 2-4 rats. The experimental procedures were approved by the Ethical Committee for the Use of Experimental Animals of the institution, and conform with the Guide for the Care and the Use of Laboratory Animals published by the US National Institute of Health (NIH Publication No. 85-23, revised 1985). 


\section{- Myocardial infarction surgery}

Myocardial infarction (MI) was induced by coronary artery ligation, as described in chapter 2. Animals were allowed to recover from surgery for 14 days in histological experiments and for 21 or 35 days in perfusion experiments.

\subsection{Perfusion experiment}

\section{- Treatment}

Osmotic minipumps were implanted subcutaneously in the neck under ether anesthesia and rats were infused with captopril (12 mg/kg.d s.c., Alzet 2001; Alza, Palo Alto, USA). Early captopril treatment (day 0-21) started immediately after sham or MI surgery and was continued for 3 weeks. Late captopril treatment (day 21-35) started 3 weeks after sham or MI surgery and captopril was infused for 2 weeks. (Osmotic minipumps were replaced every week under ether anesthesia.

\section{- Isolated heart perfusion}

Isolated hearts were perfused as described previously ${ }^{5.13}$. Under pentobarbital anesthesia ( $60 \mathrm{mg} / \mathrm{kg}$ i.p.), hearts of $\mathrm{MI}$ and sham-operated animals (day 21 or 35) were rapidly excised and immediately immersed in ice-chilled perfusion medium (see below). After removal of lung and fat tissue, hearts were connected to the aortic cannula of the perfusion system and retrograde perfusion (Langendorff perfusion model) was started at a perfusion pressure of $60 \mathrm{mmHg}$. The hearts were perfused with a modified Krebs-Henseleit solution (mM: $\mathrm{NaCl}$, 130; KCl, 5.6; $\mathrm{CaCl}_{2}, 2.2 ; \mathrm{MgCl}_{2}, 1.2 ; \mathrm{NaH}_{2} \mathrm{PO}_{4}, 1.2 ; \mathrm{NaHCO}_{3}, 25.0 ;$ glucose, 10.0; pyruvate, 5.0). The solution was maintained at $37^{\circ} \mathrm{C}$, gassed with $95 \% \mathrm{O}_{2}$ and $5 \% \mathrm{CO}_{2}$ to obtain a pH of 7.4 , and continuously filtered (1.2 $\mu \mathrm{m}$ Millipore filter) throughout the perfusion period. The hearts were paced at $5 \mathrm{~Hz}$.

Coronary flow was measured by an electromagnetic flow probe (Skalar, Delft, the Netherlands) mounted in the aortic inflow tract. Perfusion pressure was measured by a pressure transducer (Gould Spectramed DTX', Spectramed) connected to the inflow of the aortic canula. Both variables were continuously monitored online by a computer (486DX2; 40MHz) using a hemodynamic data acquisition system (HDAS; Instrumental Services, Universiteit Maastricht, the Netherlands). 


\section{- Perfusion measurements}

The hearts were prepared for retrograde perfusion at day 21 (control and early captopril) or day 35 (control and late captopril) after sham surgery or induction of MI. After equilibration of the isolated hearts, basal values of coronary flow were determined. Thereafter, coronary vasodilatation was induced by subsequent injections of $0.5 \mathrm{ml}$ of adenosine $(1 \mathrm{mM})$, nitroprusside $(1 \mathrm{mM})$ and adenosine + nitroprusside ( $1 \mathrm{mM}$ each). Maximal coronary flow was defined as smallest resistance observed.

- Measurement of infarct size

Infarct size measurement was performed, as described in chapter 2.

\subsection{Structural experiments}

\section{- Captopril treatment}

Osmotic minipumps were implanted subcutaneously in the neck under ether anesthesia and sham-operated and MI rats were infused with captopril (12 $\mathrm{mg} / \mathrm{kg} . \mathrm{d}$ s.c., Alzet 2001) from day 0 to 14 . Osmotic minipumps were replaced after one week under ether anesthesia.

\section{- Perindoprilat treatment}

Osmotic minipumps were implanted subcutaneously in the neck under ether anesthesia and sham-operated and MI rats were infused with perindoprilat (1 $\mathrm{mg} / \mathrm{kg} . \mathrm{d}$ s.c., Alzet 2002; a generous gift from dr. E. Scalbert, Servier, Paris, France) from day 0 to 14 . In pilot experiments, the doses used of perindoprilat and captopril resulted in a comparable shift of the angiotensin I dose-pressure curve (data not shown).

\section{- BrdU infusion}

Osmotic minipumps were implanted subcutaneously in the neck under ether anesthesia, and sham-operated and infarcted rats were infused with $\mathrm{BrdU}(0.8$ $\mathrm{mg} / \mathrm{kg}$.d s.c., Alzet 2001) from day 7 to 14 .

\section{- Tissue processing}

Tissue processing was performed according to materials and methods described in cliapter 2. 


\section{- Single staining with anti-5-bromo-2'-deoxyuridine (antiBrdU)}

The incorporation of $\mathrm{BrdU}$ was visualized by staining with a murine monoclonal anti-BrdU antibody, as described in chapter 2 .

\section{- Double staining procedure (GSI-antiBrdU)}

To identify DNA synthesizing endothelial nuclei in the non-infarcted part of the myocardium, transverse sections $(4 \mu \mathrm{m})$ were double stained with the lectin Griffonia Simplicifolia I (GSI) and the monoclonal anti-BrdU antibody, as described in chapter 2.

\section{- Measurements}

Total DNA synthesizing cells and the amount of DNA synthesizing endothelial cells were determined in hearts of untreated and treated sham-operated and infarcted rats. The origin of all samples was blinded to the investigators. Cell numbers were determined microscopically with an eyepiece grid (400x magnification), as described in clapter 2 . All measurements were performed by two investigators. Intra- and inter-observer variations were less than $10 \%$.

DNA synthesizing endothelial cells in the subendocardial region of the left ventricle (septum and papillary muscle) were identified based on the colocalization of both BrdU positive nuclei and GSI stained microvascular profiles. For the single BrdU staining a total of 700-1300 cells per heart were counted, whereas for the double staining at least $500 \mathrm{BrdU}$ positive nuclei were counted. The percentage of BrdU positive nuclei was calculated from the number of BrdU positive cells and the total number of cells. The percentage of BrdU positive endothelial cells was calculated from the number of BrdU positive endothelial cells and the total number of BrdU positive cells.

Infarct size was detenmined in the mid-ventricular slice, as described in chapter 2.

\subsection{Data analysis}

Only hearts with infarct sizes larger than $21 \%$ were used in the MI groups, since smaller infarcts do not have detectable hemodynamic consequences in vivo ${ }^{10}$.

Data from all experiments were compared by one-way analysis of variance followed by a post-hoc test. For comparison of groups to untreated sham animals, we used Dunnett's test, defining untreated sham rats as controls. For all other comparisons, we employed a Bonferroni procedure ${ }^{14}$. Data were expressed as mean \pm SEM. Differences were regarded to be statistically significant at a value of $\mathrm{P}<0.05$. 


\section{Results}

\subsection{Perfusion experiments}

Induction of MI resulted in an increase in heart weight, although only significantly at day 35 (table 1). Neither early nor late captopril treatment affected body and heart weight. Infarct sizes were comparable in the groups.

Basal coronary flow was comparable in sham-operated and infarcted hearts at days 21 and 35, and was not affected by captopril treatment (data not shown). Although more than $40 \%$ of the left ventricle was infarcted (table 1), there were no significant differences between maximal coronary flow in untreated shamoperated and infarcted hearts at days 21 and 35 following surgery (figure 1). Both in sham-operated and infarcted hearts, maximal coronary flow was unaffected by late captopril treatment (day 21-35). In contrast, early captopril treatment (day 021) inhibited the normalization of maximal coronary flow in infarcted hearts. In sham-operated rats, captopril treatment had no significant effect on maximal coronary flow.

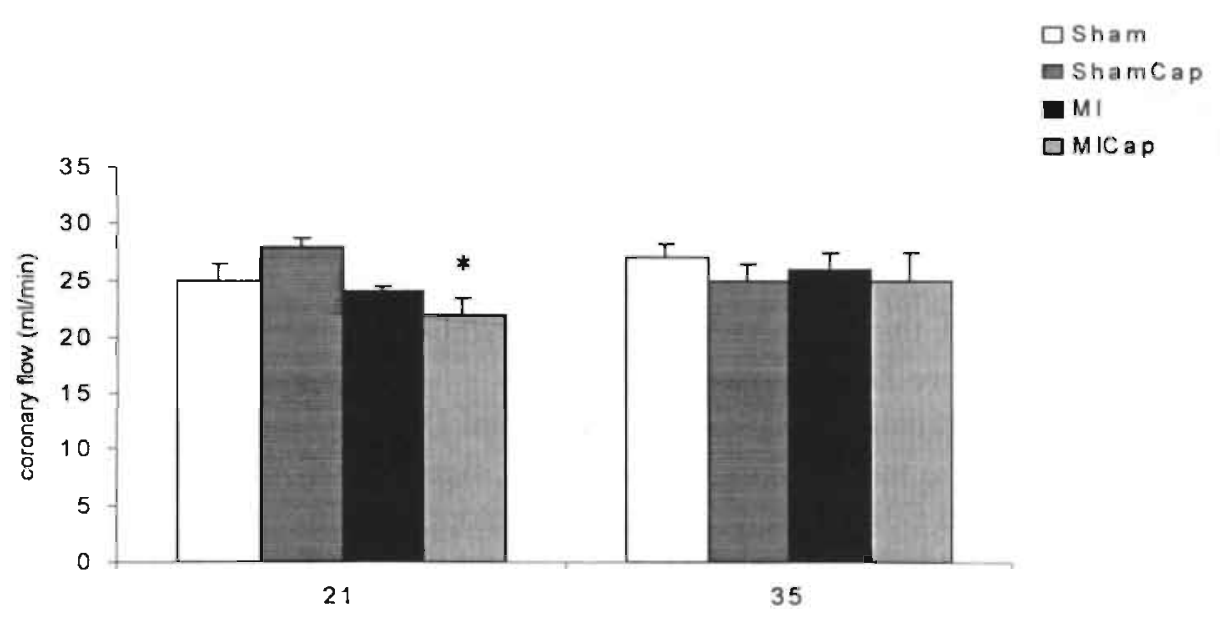

Figure 1: Maximal coronary flow of untreated and caplopril treated sham-operated (Sham) hearts, and of untreated and captopril treated infarcted (MI) hearts at day 21 and 35 after surgery. $\left({ }^{*} P<0.05\right.$ compared to captopril treated sham-operated hearts). Data are expressed as mean $+S E M$. 
Table 1: Body weight, heart weight and infarct size of untreated and treated sham-operated (sham) and infarcted (MI) rats in perfusion experimenis.

\begin{tabular}{l|ccclcc}
\hline Day & Group & Captopril & N & BW & HW & IS \\
\hline \multirow{2}{*}{21} & Sham & - & 8 & $362 \pm 11$ & $1.01 \pm 0.04$ & - \\
& Sham & + & 10 & $344 \pm 8$ & $1.02 \pm 0.04$ & - \\
& MI & - & 7 & $346 \pm 8$ & $1.13 \pm 0.08$ & $50.6 \pm 5.4$ \\
& MI & + & 9 & $344 \pm 10$ & $1.18 \pm 0.05^{\star}$ & $48.6 \pm 4.9$ \\
\multirow{5}{*}{35} & Sham & - & 9 & $378 \pm 8$ & $1.09 \pm 0.05$ & - \\
& Sham & + & 12 & $344 \pm 10$ & $1.02 \pm 0.02$ & - \\
& MI & - & 6 & $386 \pm 15$ & $1.33 \pm 0.04^{*}$ & $46.3 \pm 3.7$ \\
& MI & + & 9 & $366 \pm 13$ & $1.28 \pm 0.05^{*}$ & $42.5 \pm 5.6$ \\
\hline
\end{tabular}

Data are expressed as mean \pm SEM.

Day: days after surgery; BW: body weight (g): HW: total ventricular weight (g):

IS: infarct size ( $\%$ of left ventricle).

- Significantly different from values of corresponding sham-operated heans.

\subsection{Structural experiments}

The total labeling fraction of DNA synthesizing cells in sham-operated hearts was $7.6 \pm 1.9 \%$ (figure $2 \mathrm{~A}$ ). Of these cells $30 \pm 3 \%$ were identified as endothelial cells (figure 2B). Induction of MI almost doubled the total DNA synthesizing cell fraction at day 14 after surgery (14.9 $\pm 2.2 \%$; figure $2 \mathrm{~A}$ ). The proportion of endothelial cells of this population was comparable to that in sham-operated hearts ( $33 \pm 3 \%$; figure $2 \mathrm{~B}$ ).

Early captopril treatment (day 0-14) inhibited total DNA synthesis both in shamoperated $(4.0 \pm 0.5 \%)$ and $\mathrm{MI}$ hearts $(7.8 \pm 1.5 \%$; figure $2 \mathrm{~A}$ ). As shown in figure $2 \mathrm{~B}$, the inhibition of DNA synthesis by early captopril treatment had no effect on the proportion of endothelial cells that DNA synthesized in sham-operated hearts $(32.0 \pm 1.2 \%$ ), but was associated with a disproportionate inhibition of DNA synthesis in endothelial cells in MI hearts (10.3 $\pm 2.0 \%$ ).

Early perindoprilat treatment (day 0-14) inhibited total DNA synthesis in MI hearts (figure 2A). In contrast to captopril, the inhibition of DNA synthesis by early perindoprilat treatment had no effect on the proportion of endothelial cells that synthesized DNA in MI hearts $(32.7 \pm 1.3 \%$; figure $2 \mathrm{~B})$. 


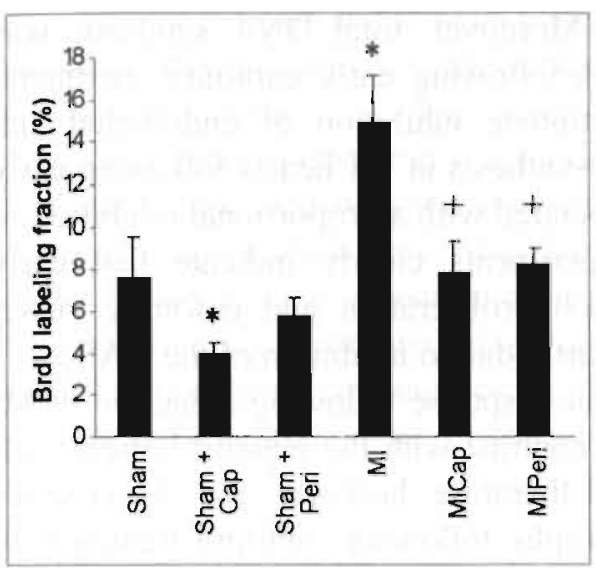

A

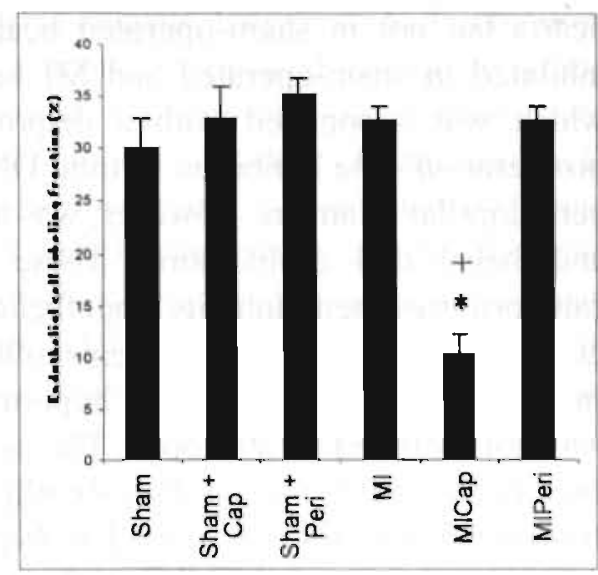

$\mathrm{B}$

Figure 2: Total BrdU labeling fraction (A) and the percentage of labeled endothelial cells of the toral labeling fraction (B) in untreated sham-operated (Sham) and infarcted (MI) hearts, in captopril (Cap) treated sham-operated and MI hearts, and in perindoprilat (Peri) treated sham-operated and $M I$ hearts. $\left({ }^{*} P<0.05\right.$ compared to untreated sham-operated hearts; ${ }^{+} P<0.05$ compared to untreated $M I$ hearts). Data are expressed as mean $\pm S E M$.

\section{Discussion}

In previous experiments, it was demonstrated that following MI remodeling processes in the non-infarcted part of the heart are characterized by an increase in collagen content, and an early increase in DNA synthesis, which is mainly confined to fibroblasts and endothelial cells (reviewed ${ }^{l}$, (chapter 2)). Recent studies from our laboratory showed a complete nomalization of maximal coronary flow within 5 weeks after MI due to a combination of recruitment of pre-existing vessels and growth of new coronary vessels in the borderzone between infarcted and surviving myocardium ${ }^{5}$. The increase in collagen content and the early rise in (total) DNA synthesis following MI could be prevented by early (0-2 weeks) captopril treatment ${ }^{3}$. In the present experiments, we investigated the effect of chronic captopril treatment on endothelial cell DNA synthesis and its possible functional consequences on maximal coronary flow.

Maximal coronary flow was comparable in hearts of untreated sham-operated and infarcted rats both at days 21 and 35 , which confirms previous findings ${ }^{5}$. Late captopril treatment did not affect maximal coronary flow. In contrast, early captopril treatment significantly decreased maximal coronary flow in infarcted 
hearts but not in sham-operated hearts. Moreover, total DNA synthesis was inhibited in sham-operated and MI hearts following early captopril treatment, which was associated with a disproportionate inhibition of endothelial cell proliferation. The inhibition of total DNA synthesis in MI hearts following early perindoprilat treatment, however, was associated with a proportional inhibition of endothelial cell proliferation. These experiments clearly indicate that early captopril treatment inhibits endothelial cell proliferation and coronary vessel growth following MI, which seems to be partly due to inhibition of the RAS.

In the present experiments, the hypertrophic response following induction of MI was not inhibited by captopril. This is in contrast with the general believe that captopril prevents cardiac hypertrophy. In literature, however, the observations conceming a regression of cardiac hypertrophy following captopril treatment in infarcted rats are not consistent. Several studies demonstrated no regression of cardiac hypertrophy following late captopril treatment ${ }^{10.15,16}$, whereas others showed a diminished heart weight in rats with large infarct sizes ${ }^{11,17}$. Also following early captopril treatment, the observations are not consistent. Both a regression ${ }^{3,10,18,19}$ and no regression of cardiac weight ${ }^{3 i-23}$ have been observed. The reason for this inconsistency is not clear, but does not seem to depend on doses used and/or duration of therapy. Due to unaltered heart weights in captopril pre-treated rats, the observed decrease in maximal coronary is not caused by a diminshed heart weight in the present experiment.

Thus far, the influence of the RAS on coronary vascularization and coronary flow has predominantly been investigated in hypertensive patients and hypertensive animal models. In hypertension, the increase in vascularization is mainly secondary to hypertrophic growth of the myocytes and to a lesser extent to normal tissue growth. The increase in vascular density or coronary flow, however, is not proportional to the hypertrophic growth response ${ }^{24-27}$, although the increase in coronary flow seems to depend on the duration of hypertension ${ }^{28,29}$. Long-term treatment with the ACE inhibitor enalapril decreased minimal coronary resistance and increased maximal coronary flow and flow reserve in hypertensive patients with angina pectoris ${ }^{30}$. In hypertension induced by aortic-banding, 4-weeks of captopril treatment decreased minimal coronary resistance, and thus increased maximal coronary flow ${ }^{20}$. Long-term ramipril treatment ( 20 week; treatment started in utero) of spontaneously hypertensive rats (SHR) increased myocardial capillary length density, independent of blood pressure reduction or inhibition of development of hypertrophy ${ }^{31}$. In the cremaster muscle, however, an inhibition of vascular growth has been observed following long-term captopril treatment in one-kidney, one clip hypertensive rats ${ }^{32}$. Thus, in 
hypertensive patients and in most hypertensive animals, long-term ACE inhibition enhances maximal coronary flow, due to a more pronounced outgrowth of the coronary vascularization. The observations in hypertension are in contrast to observations in non-hypertensive models. Angiogenic responses to angiotensin II have been described in chick chorioallantoic membrane ${ }^{33}$, in dog kidney ${ }^{34}$, and rabbit cornea ${ }^{35}$. Furthermore, Munzenmaier and Greene ${ }^{36}$ observed an increase in vessel density in rat cremaster muscle following a subpressor dose of angiotensin II. Previous studies from our laboratory showed an abolishment of the increase in capillarization in soleus muscles by ACE inhibitors in a rat model for chronic peripheral ischemia ${ }^{37}$. The observations in this latter model of ischemia are consistent with the observations in the present chronic ischemia model. The discrepancy between hypertensive models and severely ischemic models suggests that the role of the RAS in vessel growth may depend on the pathophysiological condition.

The inhibition of endothelial cell proliferation and coronary vessel growth following early ACE inhibition may depend on the blood pressure lowering effect of the ACE inhibitor. Late captopril treatment, however, did not prevent the nonnalization in maximal coronary flow, despite a comparable decrease in blood

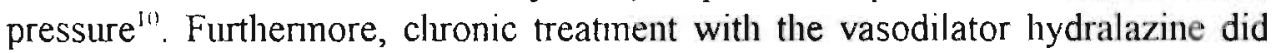
not lower total DNA synthesis in MI hearts ${ }^{3}$, suggesting a lack of involvement of blood pressure reduction in the present observations. The contribution of elevated bradykinin levels due to inhibition of its degradation can not be ruled out. Thus far, however, only a stimulatory rather than an inhibitory effect of bradykinin on endothelial cell proliferation in vitro ${ }^{38}$ and on myocardial capillary growth in hypertensive rats ${ }^{39}$ has been described.

A more likely explanation for the present observations is the prevention of (local) angiotensin II formation by inhibition of ACE. Munzenmaier and Greene observed an increase in vessel density in rat cremaster muscle following a subpressor dose of angiotensin II, which was enhanced following co-infusion of the $\mathrm{AT}_{2}$-antagonist PD123319 and inhibited following co-infusion of the $\mathrm{AT}_{1}$ antagonist losartan ${ }^{36}$. In cultured rat coronary endothelial cells, anglutensin II inhibits growth ${ }^{40.41}$. In accordance with the observations of Munzenınaier and Greene $^{36}$, this inhibitory response depended upon $\mathrm{AT}_{2}$-receptor stimulation, since addition of the $\mathrm{AT}_{2}$-antagonist PD123177 resulted in a stimulation of proliferation. Thus, in vivo the balance may be in favour of ( $\mathrm{AT}_{1}$-mediated) proliferation, whereas in vitro, inhibition ( $\mathrm{AT}_{2}$-mediated) may be favoured.

In contrast to early treatment with perindoprilat, captopril treatment resulted in a disproportionate inhibition of proliferating endothelial cells in hearts of infarcted 
rats. This suggests that in addition to the effect on the RAS, captopril may influence other angiogenic factors involved in coronary vascular remodeling following MI, like VEGF, FGF, IGF-I, and PDGF ${ }^{42}$.

Previously, worsening of cardiac function in infarcted rats following early captopril treatment was observed ${ }^{10}$. The inhibition of e.g. cardiac collagen deposition in the early phase following MI was assumed to be responsible for the deleterious effect of early captopril treatment ${ }^{1}$. The present observations suggest that also the prevention of endothelial DNA synthesis and normalization of maximal coronary flow contributes to the reduction of cardiac function in infarcted rats following early captopril treatment.

The present study employed functional and structural data to obtain an indication of endothelial cell proliferation following MI, its effect on the coronary system, and the effect of ACE inhibition thereupon. For technical reasons, we chose the septum and papillary muscles for the quantitation of BrdU/lectin staining. In contrast, maximal coronary flow is obviously an overall measure. There may be regionally different adaptive mechanisms in the ventricle remote from the infarct versus the borderzone. Our functional methods do not allow to differentiate between the effects on coronary vessels in septum, borderzone and infarcted area. However, we previously demonstrated a very low coronary flow in the infarcted area $^{5}$. Therefore, it is not likely that blood vessels in the infarct zone contribute to the observed effects in a significant manner. On the other hand, the borderzone may be an interesting area, because coronary blood flow following MI was enhanced in this areas. We tried to quantify total DNA synthesis and endothelial cell proliferation in the borderzone of MI hearts, but no reproducible data could be obtained. Nonetheless, we demonstrated both a diminished endothelial cell proliferation in the healthy part of the MI heart and a diminished maximal coronary flow. This suggests that the alterations observed in the healthy part of the infarcted heart substantially contribute to the maximal coronary blood flow. In conclusion, early captopril treatment inhibits endothelial cell proliferation and normalization of maximal coronary flow, which suggests inhibition of coronary vessel growth in infarcted rat hearts. The present experiments suggest that the RAS plays a prominent role in the coronary vessel growth as part of the remodeling processes in infarcted hearts. Considering that these processes are beneficial, inhibition of cardiac $\mathrm{ACE}$ in the early phase after myocardial infarction may inhibit the functional adaptation of the infarcted heart. Besides inhibition of cardiac ACE, captopril may also influence other angiogenic factors involved in the coronary vascular remodeling following $\mathrm{MI}$. 


\section{References}

1. Smits JFM, Passier RCJJ, Nelissen-Vrancken HJMG, Cleutjens JPM, Kuizinga MC, Daemen MJAP: Does ACE inhibition limit sinuctural changes in the heart following myocardial infarction? Eur Heart $J$ 1995; 16(Suppl.N):4651.

2. Anversa P, Beghi C, Kikkawa Y, Olivetti G: Myocardial infarction in rats. Infarct size. myocyte hypertrophy and capillary growth. Circ Res 1986;58:26-37.

3. Van-Krimpen C. Smits JF, Cleutjens JP, Debets JJ, Schoemaker RG. Struyker-Boudier HA, Bosman FT, Daemen MJ: DNA synthesis in the non-infarcted cardiac interstitium after left coronary artery ligation in the rat: effects of captopril. JMol Cell Cardiol 1991:23:12451253.

4. Cleutjens JPM, Verluyten MJA, Smits JFM, Daemen MJAP: Collagen remodeling after myocardial infarction in the rat heart. $A \mathrm{~mJ}$ Pathol 1995; 147:325-338.

5. Nelissen-Vrancken HJMG, Debets JJM, Schnoeckx LHEH, Daemen MJAP. Smits JFM: Time-related normalization of maximal coronary flow in isolated perfused hearts of rats with myocardial infarction. Circulation 1996;93:349-355.

6. Schunkert H. Dzau VJ. Tang SS. Hirsch AT. Apstein CS. Lore!I BH: Increased rat cardiac angiotensin converting enzyme activity and mRNA expression in pressure overioad left ventricular hypertrophy. Effects on coronary resistance. contractility, and relaxation. $J \mathrm{Clin}$ Invest 1990:86:1913-1920.

7. Hirsch AT, Talsness CE. Schunkert H. Paul M, Dzau VJ: Tissue-specific activation of cardiac angiotensin converting enzyme in experimental heart failure. Circ Res 1991:69:475-482.

8. Studer R, Reinecke H. Muller B. Holtz J. Just H. Drexler $\mathrm{H}$ : Increased angiotensin-I converting enzyme gene expression in the failing human heart. Quantification by competitive RNA polymcrase chain reaction. $J$ Clin Invest
1994;94:301-310.

9. Passier RCJ, Smits JFM, Verluyten MJA, Studer R, Drexler H, Daemen MJAP: Activation of angiotensin-converting-enzyme expression in the infarct zone following myocardial infarction. Am J Physiol 1995;269:H1268H1276.

10. Schoemaker RG, Debets JJ, Struyker-Boudier HA, Smits JF: Delayed but not immediate captopril therapy improves cardiac function in conscious rats following myocardial infarction. JMol Cell Cardiol 1991:23:187-197.

11. Litwin SE, Litwin CM. Raya TE. Warner AL, Goldman S: Contractility and stiffness of noninfarcted myocardium after coronary ligation in rats. Effects of chronic angiotensin converting enzyme inhibition. Circulation 1991:83:1028-1037.

12. Pfeffer MA, Pfeffer JM, Steinberg C, Finn P: Survival after an experimental myocardial infarction: beneficial effects of long-term therapy with captopril. Circulation $1985,72: 406-412$.

13. Snoeckx L.HEH, Van der Vusse GJ, Coumans WA. Willemsen PHM, Van der Nagel T. Reneman RS: Myocardial function iń normal and spontaneously hypertensive rats during reperfusion after a period of global ischaemia. Cardiovasc Res 1986;20:67-75.

14. Wallenstein S, Zucker CL, Fleiss JL: Some statistical methods useful in circulation research. Circ Res 1980;47;1-9.

15. Raya TE, Fonken SJ, Lee RW, Daugherty S Goldman S. Wong PC. Timmermans PBMWM, Morkin E: Hemodynamic effects of direct angiotensin II biockade compared to converting, enzyme inhibition in rat model of heart failure. Am J Hypertens i99 [:4:3345-3405.

16. Hirsch AT, Talsness CE, Smith AD, Schunkert H. Ingelfinger JR. Dzau VJ: Differential effects of captopril and enalapril on tissuc reninangiotensin systems in experimental heart 
failure. Circulation 1992:86:1566-1574.

17. Litwin SE, Raya TE, Warner A, Litwin CM, Goldman S: Effects of capiopril on contracuility after myocardial infarction: experimental observations. Am J Cardiol 1991;68:26D-34D.

18. Bralet J, Marie C. Mossiat C, Lecomte J-M, Gros C, Schwartz J-C: Effects of alatriopril, a mixed inhibitor of atriopeptidase and angiotensin I converting enzyme, on cardiac hypertrophy and hormonal responses in rats with myocardial infarction. Comparison with captopril. J Pharmacol Exp Ther 1994;270:814.

19. Belichard P. Savard P. Cardinal R, Nadeau R, Gosselin H, Paradis P, Rouleau $\Omega$ : Markedly different effects on ventricular remodeling result in a decrease in inducibility of ventricular arrhythmias. J Am Coll Cardiol 1994:23:505513.

20. Regan CP. Anderson PG. Bishop SP, Berecek KH: Captopril prevents vascular and fibrotic changes but not cardiac hypertrophy in aorticbanded rats Am J Physiol 1996;271:H906H913.

21. Capasso JM. Anversa P. Mechanical performance of spared myocytes after myocardial infarction in rats: effects of captopril treatment. Am J Physiol 1992:263:H841-H849.

22. Mill JG, Gomes APV. Carrara AB. Gomes MGS. Vassallo DV: Influence of chronic captopril therapy on the mechanical performance of the infareted rat heart. Pharmacol Res 1994:29:77-88.

23. Capasso JM, Li P. Meggs LG. Herman MV, Anversa $P$ : Eflicacy of angiotensin-converting enzyme inhibition and ATI receptor blockade on cardiac pump performance after myocardial infarction in rats. $J$ Cardiorase Pharmacol 1994:23:584-593.

24. Vitullo JC, Peñn MS. Rakusan K. Wicker P: Effects of hypertension and aging on coronary arteriolar density Hypertension 1993:21:406+14 .
25. Tomanek RJ: Capillany and pre-capillary coronary vascular growth during left ventricular hypertrophy. Can J Physiol Pharmacol 1986;2:114-119.

26. Anversa P, Ricci R. Oliveti G: Coronary capillaries during normal and pathological growth. Can J Physiol Pharmacol 1986:2:104113.

27. Mall G. Zinmer G, Baden S. Matteldt T: Capillary neoformation in the rat heartstereological studies on papillary muscles in hypentrophy and plysiologic growth. Basic Res Cardiol' 1990;85:531-540.

28. Tomanek RJ. Schalk KA. Marcus ML, Harrison DG: Coronary angiogenesis during long-term lypertension and left ventricular hypertrophy in dogs. Circ Res 1989;65:352-359.

29. O'Keefe DD. Hoffman JIE. Cheitlin R. O'Neill MJ. Allard JR. Shapkin E: Coronary blood flow in experimental canince left ventricular hyertrophy. (irc Re's 1978:4:43-51

30. Motz W. Straner BE: Improvement of coronary flow reserve after long-tern therapy with enalapril. Hypertension 1996:27:1031-1038.

31. Unger $T$, Mattfeldt $T$, Lamberty $Y$, Bock $P$. Mall G. Linz W. Scholkens BA. Gohlke P: Effect of early onset angiotensin converting enzyme inhibition on myocardial capillaries. Hypertension 1992;20:478-482.

32. Wang DH. Prewitt RL: Captopril reduces aortic and micrewascular growth in hypertensive and normotensive rats. Hypertension 1990: 15:6877.

33. Le-Noble FAC. Hekking JWM. Van-Straaten HWM, Slaaf DW, Struyker-Boudier HAJ: Angiotensin II stimulates angiogenesis in the chorio-allantoic membrane of the chick embryo. Eur J Pharmacol 1991:195:305-306.

34 Fernandez LA. Caride VJ, Twickler J. Galardy $R E$ : Renin-angiotensin and development of collateral circulation after renal ischemia. $A m J$ Phvsiol 1982:243:H869-H875. 
35. Fernandez L, Twickler J, Mead A:

Neovascularization produced by angiotensin II. $J$ Lab Clin Med 1985: 105:141-145.

36. Munzenmaier DH. Greene AS: Opposing actions of angiotensin IT on microvascular growth and aricrial blood pressure. Hyperiension 1996.27:759-765.

37. Nelissen-Vrancken HJMG. Struyker-Boudier HAJ, Daemen MJAP. Smits JFM: Antihypertensive therapy and adaptive mechanisms in peripheral ischemia Hypertension 1993:22:780-788.

38. Ziche M. Parenti A. Morbidelli L, Meiniger CJ, Granger HJ. Ledda F: The effect of vasoactive factors on the growth of coronary endothelial cells. Cardiologia 1992:37:573-575.

39. Gohlke P. Kuwer I. Sclmnell A. Amann K. Mall G. Unger T: Blockade of bradykinin B2 receptors prevents the increase in capillary density induced by chronic angiotensinconverting enzyme inhibitor treatment in stroke-prone spontaneously hypertensive rats. Hypertension 1997:29;478-482.

40. Metsarinne KP, Stoll M, Gohlke P, Paul M, Unger T: Angiotensin II is antiproliferative for coronary eridothelial cells in vitro. Pharm Pharmacol Lett 1992;2:150-152.

41. Stoll M, Steckelings M, Paul M, Bottari SP, Metzger R, Unger T: The angiotensin AT2receptor mediates inhibition of cell proliferation in coronary endothelial cells. J Clin Invest 1995:95:651-657.

42. Sunderkotter C. Steinbrink K, Goebeler M, Bhardwaj J, Sorg C: Macrophages and angiogenesis. J Leukoc Biol 1994:55:410-422. 


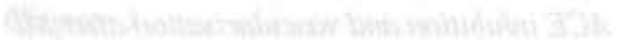




\section{$\mathrm{AT}_{2}$ receptor blockade reduces cardiac interstitial cell DNA synthesis and cardiac function after rat myocardial infarction}

\section{Summary}

The objective of the study was to investigate the involvement of angiotensin II receptor subtypes $I\left(A T_{1}\right)$ and $2\left(A T_{2}\right)$ in total interstitial cell and endothelial cell DNA synthesis and cardiac function after myocardial infarction (MI) in the rat. Rais with a MI were treated with either the AT, receptor antagonist GRI38950C (2 $\mathrm{mg} / \mathrm{kg}$ day) or the $A T_{2}$ receptor antagonist PDI23319 (3 $\mathrm{mg} / \mathrm{kg}$ day). Total interstitial cell (that is endothelial cells and fibroblast-like cells) DNA synthesis in the interventricular septum was significantly increased 2 weeks after MI (chapter 2). $33 \pm 3 \%$ of DNA synthesizing cells were identified as endothelial cells (chapter 2). PDI23319, but not GR138950C significantly reduced total interstitial DNA synthesis. Both agents did not alter the fraction of DNA synthesizing endothelial cells.

The effects on cardiac function were studied in parallel groups. MI reduced both cardiac output (CO) and stroke volume at 3 weeks after MI. PDI23319 reduced $C O$, whereas $G R I 38950 \mathrm{C}$ did not affect cardiac function. 
Thus, the data show that $A T_{2}$ receptor blockade, but not $A T_{1}$ receptor blockade early after rat myocardial infarction inhibits interstitial DNA synthesis and decreases cardiac function.

\section{Introduction}

Following myocardial infarction (MI), a series of changes occurs which affect the infarcted and non-infarcted areas of the left ventricle ${ }^{20}$. These changes are referred to as cardiac remodeling, and include changes in the myocyte ${ }^{21}$ and nonmyocyte compartment. In the latter, interstitial collagen increase ${ }^{14-16}$, whereas capillary density decreases ${ }^{22}$. Previous work in our laboratory has shown that DNA synthesis transiently increases in the non-infarcted part of the myocardium in the rat heart in the first 2 weeks after myocardial infarction. This increase is mainly found in interstitial cells ${ }^{23}$, comprised of two major cell types: endothelial cells and fibroblasts ${ }^{18,24}$ (chapter 2).

The renin-angiotensin system seems to be involved in the regulation of interstitial DNA synthesis after MI, since ACE inhibition with captopril during the first 2 weeks after MI inhibits the increase in DNA synthesis ${ }^{23}$. Although recent studies show an upregulation of ACE, renin and angiotensin II receptors ${ }^{1+6}$ in the rat infarct model, interstitial DNA synthesis after MI was only partly affected by the $\mathrm{AT}_{1}$ receptor antagonist losartan?, suggesting a role for the $\mathrm{AT}_{2}$ receptor in the regulation of interstitial DNA synthesis after MI.

Also cardiac function following $\mathrm{MI}$ is affected differentially by treatment with captopril $^{25}$ or losartan ${ }^{7.26}$. Similar to observations by others ${ }^{27}$, captopril, when administered from 3-5 wecks post MI, improved cardiac function, whereas early treatment during the first 3 weeks after infarction further attenuated cardiac function ${ }^{3}$. I osartan had neither of these effects ${ }^{7.26}$, although it was found to reduce cardiac filling pressures ${ }^{26}$. This suggests that the functional effects of $\mathrm{ACE}$-inhibition may not depend upon the $\mathrm{AT}_{1}$, but on the $\mathrm{AT}_{2}$ receptor.

To test this hypothesis, DNA synthesis in interstitial fibroblasts and endothelial cells was quantitied in $\mathrm{MI}$ rats that were treated with the $\mathrm{AT}_{1}$ receptor antagonist GR138950C or the $\mathrm{AT}_{2}$ receptor antagonist PD123319. In parallel experiments, the hemodynamic effects of both substances were studied. 


\section{Materials and methods}

- Animals

Normotensive adult male Wistar rats (Winkelmann, Borchen, Germany), $\mathbf{n}=101$, weighing $295 \pm 4 \mathrm{~g}$ (mean $\pm \mathrm{SEM}$ ) at the time of surgery, were used cf. chapter 2 .

- Coronary artery ligation

Myocardial infarction was induced by ligation of the left anterior descending coronary artery (LAD), as described in chapter?

\subsection{Structural methodologies}

- Infusion of 5bromo2'deoxyuridine

To label DNA synthesizing cells, all animals received 5-bromo-2'deoxyuridine (BrdU, Serva, Heidelberg, Germany; infusion rate $0.8 \mathrm{mg} / \mathrm{kg} /$ day), as described in chapter 2.

\section{- Tissue processing}

Tissue processing was performed according to materials and methods described in chapter 2.

\section{- Measurement of infarct size}

Infarct size measurement was performed, as described in chapter 2.

- Single staining with anti-5-bromo-2'-deoxyuridine (antiBrdU)

The incorporation of BrdU was visualized by staining with a murine monoclonal anti-BrdU antibody, as described in chapter 2 .

\section{- Double staining procedure (GSI-antiBrdU)}

To identify DNA synthesizing endothelial nuclei in the non-infarcted part of the myocardium, transverse sections $(4 \mu \mathrm{m})$ were double stained with the lectin Griffonia Simplicifolia I (GSI) and the monoclonal anti-BrdU antibody, as described in chapter 2.

\section{- Counting of total and endothelial cell DNA synthesis}

Total DNA synthesizing cells and the amount of DNA synthesizing endothelial cells were determined, as described in chapter 2 . The investigators were blinded for the treatment group. The total labeling fraction $\left(\mathrm{LF}=\right.$ number of $\mathrm{BrdU}^{+} /$total 
number of nuclei counted $\times 100 \%$ ) was calculated.The endothelial cell labeling fraction (ECLF) was calculated from the number of $\mathrm{BrdU}^{+}$endothelial cells and the total number of $\mathrm{BrdU}^{+}$cells (see chapter 2).

\subsection{Hemodynamic methodologies}

\section{- Implantation of measuring equipment}

Animals were equipped with an electromagnetic flow probe $(2.7 \mathrm{~mm}$ diameter; Skalar, Delft, The Netherlands) on the ascending aorta at least 1 week before the experiments according to previously described methods ${ }^{25}$.

Five to six days later, animals were anesthetized with ether and implanted with a PE-10 catheter in the abdominal aorta through a femoral artery to measure arterial blood pressure (BP). Furthermore, a Silastic catheter was advanced into the thoracic vena cava for measurement of central venous pressure (CVP). All catheters were exteriorized in the neck. After the latter operation, animals were allowed to recover for 1-2 days before experiments were started.

\section{- Measurements and protocol}

On the experimental day, the electromagnetic flow probe was connected to a sinewave flowmeter (model MDL 401, Skalar) to measure blood flow through the ascending aorta. Although this flow comprises cardiac output (CO) minus coronary blood flow, we refer to it as $\mathrm{CO}$. The baseline was established by taking late diastolic blood flow as zero. The arterial and central venous catheters were connected to low-volume displacement pressure transducers (CP01; Century Technology, Inglewood, CA, USA). All signals were fed into an AT-compatible microcomputer, sampling all signals at $500 \mathrm{~Hz}$ each. Mean values for arterial BP (MAP) and CVP were obtained by digital integration. Stroke volume (SV) was calculated from the flow signal by integration of each beat. Total peripheral resistance (TPR) was calculated as (MAP-CVP)/CO. All derivations were made on-line and stored on disk for later processing.

After the animals were acclimated for 45-60 min, recordings were made for 15 min.

\subsection{Drug treatments}

Drugs or saline were infused by subcutaneously implanted minipumps (PDI23319: Alzet 2MLl; GR138950C and saline: Alzet 2001), which were 
replaced after 1 week. GR138950C (2 $\mathrm{mg} / \mathrm{kg} /$ day) was dissolved in $0.8 \%$ $\mathrm{NaHCO}_{3}$ and $10 \%$ ethanol. PD123319 (3 mg/kg/day) was dissolved in $0.9 \%$ $\mathrm{NaCl}$. Saline infused $\mathrm{MI}$ or sham rats served as controls.

The dose of GR $138950 \mathrm{C}$ was based on pilot-studies, in which $2 \mathrm{mg} / \mathrm{kg} /$ day was found to induce a 20 -fold right-ward shift of the dose-pressor-response curve to angiotensin II. Infusion of PD123319 at a dose of $3 \mathrm{mg} / \mathrm{kg} /$ day in the rat results in plasma levels around $100 \mathrm{nM}^{28}$. Since the IC50 of PD123319 for the $\mathrm{AT}_{2}$ receptor is approximately $10 \mathrm{nM}^{29}$, infusion of $3 \mathrm{mg} / \mathrm{kg}$ /day PD123319 should result in an effective $\mathrm{AT}_{2}$ receptor-blocking dose, without affecting the $\mathrm{AT}_{1}$ receptor. The latter was verified in a separate group of animals, which were subcutaneously infused with saline $(n=6)$ or $3 \mathrm{mg} / \mathrm{kg} /$ day PD123319 $(\mathrm{n}=6)$ during 2 weeks. At the end of the infusion period, animals were anesthetized with pentobarbital $(60 \mathrm{mg} / \mathrm{kg}$, i.p.) and catheters were inserted into the right femoral vein for injections, and into the right femoral artery for measurement of blood pressure. Animals were placed on a heating pad $\left(37^{\circ} \mathrm{C}\right)$ and, following establishment of base line, $0.03 \mu \mathrm{g}$ angiotensin II was injected. In saline-infused animals, the resultant increase in mean arterial pressure (MAP) was $36 \pm 3$ $\mathrm{mmHg}$; in the PD 123319-infused animals, this dose of angiotensin II increased MAP $37 \pm 3 \mathrm{mmHg}$, suggesting a total lack of inhibition of the pressor response to angiotensin $\Pi$, which we interpret as a lack of $\mathrm{AT}_{1}$ receptor antagonism.

In structural studies animals were infused from 0-2 weeks after MI, and from 0-3 weeks for the hemodynamic studies.

\subsection{Statistics}

Data are expressed as means \pm SEM. Groups were compared by one-way analysis of variance (ANOVA) and Bonferroni-modified t-test ${ }^{30}$. The level of statistical significance was assumed to be at $\mathrm{P}<0.05$.

\section{Results}

\subsection{Structural experiments}

The starting body weights in all experimental groups were similar (table 1). Induction of MI had no effect on body weight. Treatment of infarcted rats with GR138950C was associated with a small increase of the body weight. The infarct size in PD123319-treated animals was comparable with the untreated control group. In GR138950C-treated animals infarct size was significantly larger than in the untreated and PD123319-treated groups (P.0.05). 
Table 1: Characteristics of animals used for structural studies

\begin{tabular}{l|cccc}
\hline & Sham & MI & $\begin{array}{c}\text { MI- } \\
\text { PD123319 }\end{array}$ & $\begin{array}{c}\text { MI- } \\
\text { GR138950C }\end{array}$ \\
\hline Body weight start (g) & $295 \pm 4$ & $287 \pm 7$ & $305 \pm 3$ & $303 \pm 7$ \\
Body weight end (g) & $314 \pm 6$ & $291 \pm 10$ & $306 \pm 4$ & $327 \pm 7^{*}$ \\
Ventricular weight (g) & $1.07 \pm 0.03$ & $0.95 \pm 0.04$ & $0.87 \pm 0.04$ & $0.96 \pm 0.05$ \\
Ventricular weight/ body & $3.45 \pm 0.14$ & $3.26 \pm 0.09$ & $2.88 \pm 0.09$ & $2.94 \pm 0.22$ \\
weight (g/1000g) & & & & \\
Mean infarct size (\%) & - & $44 \pm 2$ & $45 \pm 3$ & $52 \pm 1^{*}$ \\
$\mathrm{~N}$ & 14 & 15 & 8 & 6 \\
\hline
\end{tabular}

$\because \mathrm{P}<0.05$ as compared to MI

- Total interstitial, endothelial and fibroblast DNA synthesis

Infarct induction caused a three-fold increase in interstitial DNA synthesis in the non-infarcted septum of the left ventricle from $5.9 \pm 1.1 \%$ in sham animals to $15.9 \pm 1.4 \%$ in infarct animals (chapter 2 ). PD123319 significantly reduced total labeling to $10.2 \pm 1.6 \%$. GR $138950 \mathrm{C}$ had no effects on BrdU-incorporation (15.2 $\pm 2.6 \%$, fig. 1). In sham animals approximately one-third of the cells that synthesized DNA were positively identified as endothelial cells (fig. 2), which means that approximately two-thirds of the cells synthesizing DNA were fibroblasts. Neither infarct induction nor infarct induction and PD123319treatment altered the fraction of endothelial cells synthesizing DNA (32.9 \pm 2.6 and $25.5 \pm 3.0 \%$ in untreated and PD123319-treated MI animals, respectively). Also, GR $138950 \mathrm{C}$-treatment of infarct animals did not affect the fraction of endothelial cells synthesizing DNA ( $27.9 \pm 0.6 \%$, fig. 2$)$. 


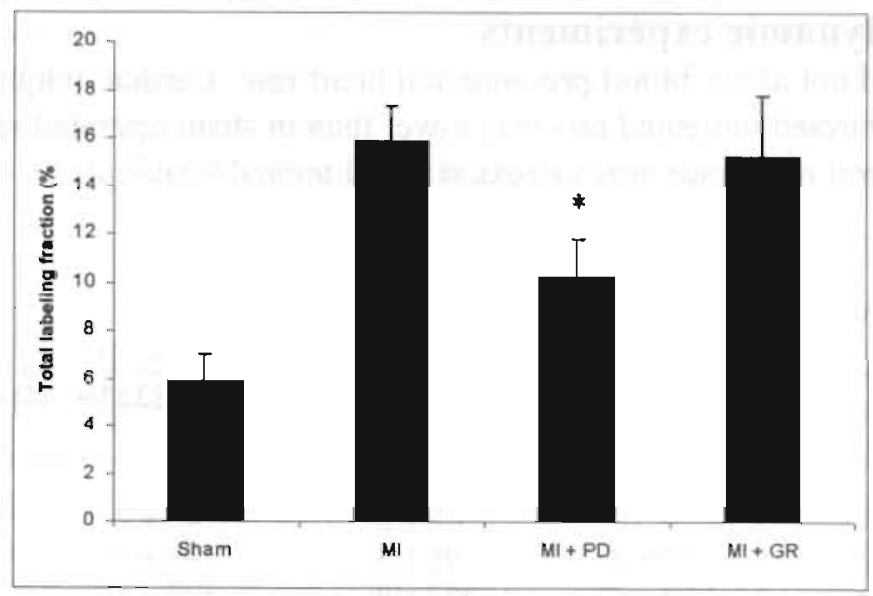

Figure 1: BrdU-labeling of interstitial cells in the left ventricular wall in non-treated sham operated animals (Sham), non-treated infarct animals (MI), GR138950C-treated infarct animals $(M I+G R)$, and PD123319-treated infarct animals $(M I+P D) 14$ days after surgery.

*, $P<0.05$ as compared to MI.

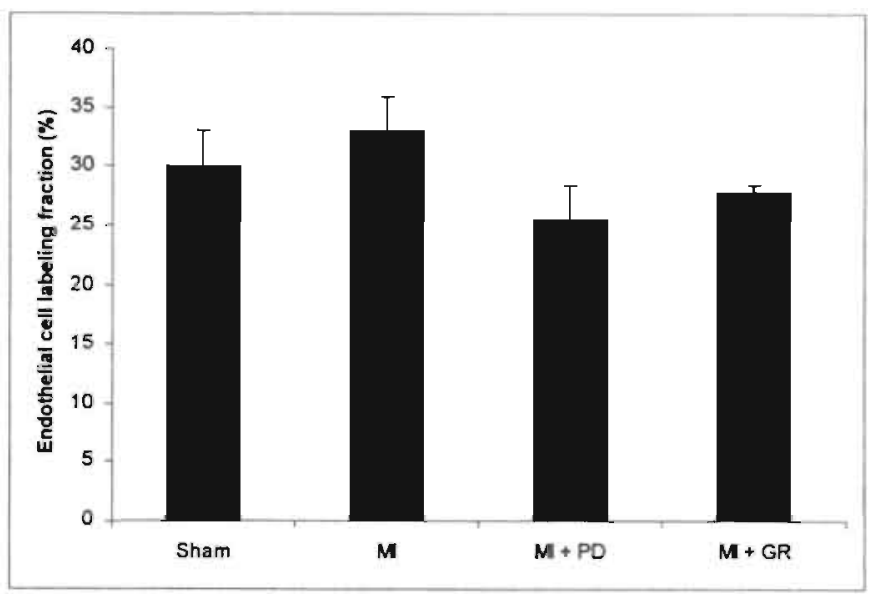

Figure 2: Fraction of endothelial cells incorporating BrilU in the lefi ventricular wall in non-Ireated sham operated animals (Sham), non-treated infarct animals (MI). GRI38950C-treated infarct animals (MI GR), and PDI23319-treated infarct animals $(M I+P D) 14$ doys after surgery. 


\subsection{Hemodynamic experiments}

Infarction did not affect blood pressure and heart rate. Cardiac output and stroke volume in infarcted untreated rats was lower than in sham operated rats (table 2). Total peripheral resistance was increased in MI animals (table 2).

Table 2: Hemodynamic characteristics of the treaiment groups

\begin{tabular}{l|cccc}
\hline & Sham & MI & MI-PD123319 & MI-GR138950C \\
\hline & & & & \\
Infarct size (\%) & - & $42 \pm 2$ & $45 \pm 2$ & $48 \pm 3$ \\
MAP (mmHg) & $97 \pm 2$ & $95 \pm 3$ & $95 \pm 3$ & $81 \pm 3^{\star+}$ \\
HR (beats/min) & $359 \pm 12$ & $382 \pm 8$ & $366 \pm 10$ & $379 \pm 10$ \\
TPR(mmHg.min/ml) & $1.15 \pm 0.05$ & $1.46 \pm 0.09^{+}$ & $1.65 \pm 0.16$ & $1.11 \pm 0.08$ \\
CO (ml/min) & $86 \pm 3$ & $70 \pm 2^{+}$ & $61 \pm 4^{\star}$ & $73 \pm 5$ \\
SV $(\mu l / m i n)$ & $246 \pm 11$ & $191 \pm 7^{*}$ & $167 \pm 14^{*}$ & $191 \pm 13$ \\
$N$ & 19 & 24 & 8 & 7 \\
& & & & \\
\hline
\end{tabular}

MAP: mean arterial pressure; HR: heart rate; TPR: total peripheral resistance; $\mathrm{CO}$, cardiac output; SV, stroke volume.

*, $\mathrm{P}<0.05$ as comparcd to MI:, $\mathrm{P}<0.05$ as compared to sham

\section{- Hemodynamic effects of AT receptor blockade}

GR138950C, but not PD123319, significantly reduced blood pressure (table 2). Total peripheral resistance was not affected by PD123319; GR138950C tended to reduce total peripheral resistance. Heart rates were similar in all groups. Cardiac output and stroke volume in GR138950C-treated rats were similar to those in untreated rats, but lower in PD123319-treated animals (table 2).

\section{Discussion}

This study contains several major findings. First, it describes that $\mathrm{AT}_{2}$ but not $\mathrm{AT}_{1}$ receptor blockade prevents the increase of total interstitial DNA synthesis post $\mathrm{MI}$, and shows that the phenotype of interstitial cells synthesizing DNA does not change during $\mathrm{AT}_{2}$ receptor blockade. This indicates that the increase in DNA synthesis in cardiac endothelial cells and interstitial fibroblasts after myocardial 
infarction is mediated through $\mathrm{AT}_{2}$ receptors. Second, treatment with PD) 23319 further attenuated cardiac function, whereas GR138950C had no such effect, suggesting that the hemodynamic effects of $\mathrm{AT}_{2}$ receptor blockade after $\mathrm{MI}$ may depend upon reduction of interstitial cell DNA synthesis in the hypertrophying myocardium.

\subsection{Post-infarction DNA synthesis}

Previous studies have shown that the post-infarction increase in DNA synthesis is a transient event occurring early in the first 2 weeks after induction of a myocardial infarction in the rat ${ }^{23}$. This increase in interstitial cell DNA synthesis is most probably stimulated by angiotensin II, since systemic and local levels of angiotensin II are increased in the first weeks after myocardial infarction ${ }^{34}$, and the increase in interstitial DNA synthesis can be blocked by ACE-inhibitors ${ }^{2.3}$ and by an $\mathrm{AT}_{2}$ antagonist (this study). PD123319 did not return DNA synthesis to sham levels, which is different from the results that have been obtained after ACE inhibition with captopril ${ }^{23}$ or perindoprilat (chapter 3), where DNA synthesis did return to sham levels. This differential effect of $\mathrm{AT}_{2}$ receptor blockade and $\mathrm{ACE}$ inhibition may suggest that other factors than angiotensin Il may be involved. Candidate factors are aldosterone ${ }^{8,9}$, bradykinin ${ }^{10-12}$ and chymases $^{13}$, which all have been shown to be present, or even actively involved in the remodeling after infarction. There are, however, no direct data on their effect on interstitial DNA synthesis after infarction in the rat.

The increase in interstitial collagen that is present in the non-infarcted region after infarction $^{14-17}$ is most probably derived from the increased number of cardiac interstitial fibroblasts, which are known to increase the synthesis of collagen type I and III mRNA in the non-infarcted regions ${ }^{18}$.

\subsection{Angiotensin receptor subtypes, post-infarction DNA synthesis and cardiac function.}

Both $\mathrm{AT}_{1}$ and $\mathrm{AT}_{2}$ receptors are expressed in the normal rat heart. An equal proportion of both subtypes ${ }^{31.32}$, as well as predominance of $\mathrm{AT}_{1}$ receptors in the normal myocardium has been reported ${ }^{33,34}$. Whereas Sun and Weber ${ }^{6}$ found an upregulation of predominantly $\mathrm{AT}_{1}$ receptors, Nio et $\mathrm{al}^{2}{ }^{2}$ described that both receptor subtypes are upregulated in the infarct as well as in the remote tissue. The nonnal human heart is known to have comparable numbers of $\mathrm{AT}_{1}$ and $\mathrm{AT}_{2}$ 
receptors ${ }^{35}$. In human heart failure a downregulation of only $\mathrm{AT}_{1}$ receptors ${ }^{36,37}$ or both $\mathrm{AT}_{1}$ and $\mathrm{AT}_{2}$ recepors has been described ${ }^{35}$, as well as an upregulation of $\mathrm{AT}_{2}$ receptors ${ }^{38}$.

AT receptors are present on cardiomyocytes and non-myocytes. Angiotensin II exerts its hypertrophic effects on cardiomyocytes through $\mathrm{AT}_{1}$ receptors. In addition, $\mathrm{AT}_{1}$ receptors are considered to have mitogenic effects on cultured cardiac fibroblasts ${ }^{39}$.

Although neither $\mathrm{AT}_{1}$ receptor nor $\mathrm{AT}_{2}$ receptor blockade changed the fraction of DNA synthesizing endothelial cells, $\mathrm{AT}_{2}$, but not $\mathrm{AT}_{1}$ receptor blockade did reduce the total number of DNA synthesizing interstitial cells. This indicates that $\mathrm{AT}_{2}$ but not $\mathrm{AT}_{1}$ receptors are involved in the regulation of total interstitial cell (endothelial cells and fibroblasts) DNA synthesis in the heart after myocardial infarction, and suggests that $\mathrm{AT}_{2}$ receptorsare localized on cardiac endothelial cells and fibroblasts. Recent unpublished data from our own group, using RT$P C R$ and in situ hybridization confirm an upregulation of $A T_{1}$ and $\mathrm{AT}_{2}$ receptor mRNA in fibroblast-like cells and in endothelial cells in the infarct.

Our in vivo functional studies show that the inhibitory effect of early $\mathrm{AT}_{2}$ receptor blockade on DNA synthesis is associated with a further attenuation of the already impaired function after MI. Early $\mathrm{AT}_{1}$ receptor blockade had no effect on cardiac function, as has been shown before with another $\mathrm{AT}_{1}$ receptor antagonist ${ }^{7.26}$. The inhibitory effects of $\mathrm{AT}_{2}$ receptor blockade on interstitial cell DNA synthesis and cardiac function suggest that prevention of vascular endothelial cell or interstitial fibroblast DNA synthesis in the non-infarcted myocardium may be associated with a reduction of cardiac function.

Our finding that $\mathrm{AT}_{2}$ receptor mediates proliferative effects in cardial endothelial cells and fibroblasts is in contrast with reports from in vitro studies in endothelial cells ${ }^{40}$, cardiac cells $s^{41}$, and vascular smooth muscle cells ${ }^{42}$, where the $\mathrm{AT}_{2}$ receptor has antiproliferative effects. Although we have no clear explanation for this apparent discrepancy between those data and the data presented here, the results of the group of Levy et al. ${ }^{19}$ also indicate a reduction of DNA synthesis in vascular smooth muscle cells after treatment with the $\mathrm{AT}_{2}$ receptor blocker $\mathrm{PD} 123319$. Thus, although the $\mathrm{AT}_{2}$ receptor may clearly mediate antiproliferative effects in vitro, it may not be unequivocal in vivo, since there are at least two independent observations that indicate that the $\mathrm{AT}_{2}$ receptor may mediate proliferative effects in vivo.

Although many studies detail $\mathrm{AT}_{2}$ receptor localization and clanging patterns of receptor expression throughout development, information concerning its possible function and signalling mechanisms has emerged only recently. The $\mathrm{AT}_{2}$ receptor 
subtype is highly expressed in the developing fetus and rapidly disappears after birth, suggesting an association between this receptor and cell growth and/or differentiation ${ }^{43}$. Upregulation of cardiac $\mathrm{AT}_{2}$ receptors has also been reported in several pathophysiological conditions. In a model of pressure overload hypertrophy, the hearts were found to contain primarily $\mathrm{AT}_{2}$ receptors ${ }^{34}$. Increased expression of $\mathrm{AT}_{2}$ receptors has been shown after myocardial infarction ${ }^{2}$ and in cardiac hypertrophy induced by an AV-shunt ${ }^{44.45}$. In this context, it is conceivable that the $\mathrm{AT}_{2}$ receptor is in some way involved in these pathological processes. Our findings suggest that the $\mathrm{AT}_{2}$ receptor mediates fibroblast and endothelial cell DNA synthesis after myocardial infarction.

As in some studies PD123319 has been shown to be not entirely specific for $\mathrm{AT}_{2}$ receptors having affinity for some particular $\mathrm{AT}_{1}$ binding sites ${ }^{46}$, it could be argued that our experiment reflects $\mathrm{AT}_{1}$ rather than $\mathrm{AT}_{2}$ receptor blockade. This is unlikely, however, because the $\mathrm{AT}_{1}$ receptor antagonist GR138950C was ineffective. Alternatively, it could be argued that nonspecific receptor binding with PD123319 has occurred because of high dosing. This also is not very likely, since our infusion rate of $3 \mathrm{mg} / \mathrm{kg} /$ day is well below an infusion rate of 1000 $\mu \mathrm{g} / \mathrm{kg} / \mathrm{min} \mathrm{PD} 123319$, which should be expected to interact exclusively with $\mathrm{AT}_{2}$ receptors ${ }^{47}$. Moreover we did not observe any effect of PD123319 on the angiotensin II-induced pressor response.

The lack of effect of GR138950C on interstitial DNA synthesis seems to be in conflict with earlier data from our lab ${ }^{7}$, which show that the $\mathrm{AT}_{1}$ receptor antagonist losartan did reduce interstitial DNA synthesis as compared to untreated MI ( $16 \%$ for the losartan group vs $23 \%$ for the MI group), but did not reduce DNA synthesis to sham levels (5\%). In the present study GR138950C did not reduce DNA synthesis (15.2\%) as compared to the infarct group (15.9\%; $\mathrm{n}=14$ ). Thus, it appears that DNA synthesis in the losartan and GR138950C groups are not different, but that DNA synthesis in the present group of untreated infarct animals is lower than the DNA synthesis in the group of infarct animals in the former paper. Infarct sizes did not differ between the two untreated infarct groups.

\subsection{Possible implications of the findings}

The positive correlation between a reduction in endothelial cell and fibroblast proliferation and a reduction in cardiac function, suggests that fibroblast and endothelial cell proliferation early after infarction is beneficial for the heart. Since we are not able to selectively decrease fibroblast proliferation and leave 
endothelial cell proliferation intact, it is impossible to further specify whether inhibition of fibroblast or endothelial cell proliferation is responsible for the decrease in cardiac function. Since we and others ${ }^{7,12,17,48}$ have shown that $\mathrm{AT}_{1}$ receptor blockade reduces the collagen content, but not cardiac function, we would favor the endothelial cell, where proliferation is indeed an integral part of the angiogenic process in both the infarct and non-infarcted area ${ }^{49-51}$ (chapter 2). Although the step from rat experiments to human patients is a large one, which should be taken with great care, the results of the recently published ELITE trial $^{52}$, that showed AT, receptor blockade was superior over ACE-inhibition, may indicate that selective $\mathrm{AT}_{2}$ receptor stimulation (by blocking the $\mathrm{AT}_{1}$ receptor in conditions of elevated angiotensin II levels) may be beneficial for the heart. It remains to be proven whether the positive results in the human studies are indeed due to positive effects on interstitial DNA synthesis.

\section{Acknowledgements}

Glaxo (UK) and Parke-Davis (USA) are gratefully acknowledged for their gifts of GR $138950 \mathrm{C}$ and PD123319, respectively. 


\section{References}

1. Meggs LG, Coupet J, Huang H. Cheng W. Li P, Capasso JM. Homcy CJ, Anversa P: Regulation of angiotensin II reccptors on ventricular myocytes after inyocardial infarction in rats. Circ Res 1993;72:1149-1162

2. Nio $Y$, Matsubara $H$. Murasiwa S, Kanasaki M, Inada M: Regulation of gene transcription of angiotensin II receptor subtypes in myocardial infarction. J Clin Jmest 1995:95:46-54.

3. Passier RCJJ, Smits JFM, Verluyten MJA, Studer R. Drexler H. Daemen MJAP: Activation of angiotensin-converting-enzyme cxpression in the infarct zone following myocardial infarction. $A m J / h$ wsiol 1995:269:H1268$\mathrm{H} 1276$.

4. Passier RCJJ. Smits JFM. Verluyten MJA. Diemen MJAP: Expression and localization of renin and angiotensinogen in rat heart after myocardial infarction. Am $J$ Physiol 1996:271:H1040-H1048.

5. Sun $Y$, Weber KT: Angiotensin converling enzyme and myofibroblasts during tissue repair in the rat heart. J.Mol Cell Cardiol 1996:28:851-858

6. Sun Y, Weber KT: Cells expressing angiotensin II receptors in fibrous tissue of rat heart. Cardiovase Res 1996:31:518-525

7. Smits JFM. Van Krimpen C. Schocmaker RG, Cleutjens JPM. Dacmen MJAP: Angiotensin II receptor blockade after myocardial infarction in rats: effects on hemodynamics. myocardial DNA synthesis and interstitial colligen content. $J$ Cardiovase Pharmacol 1992:20:772-778.

8. Brilla CG, Weber KT: Mineralocorticoid excess, dietary sodium, and inyocardial fibrosis. $J$ Lab Clin Med 1992;120:893-901.

9. Robert V. Silvestre JS. Charlemangne D. Sabri A. Trouve P. Wassef M. Swynghedauw B.
Delcraye C: Biological determants of aldosterone-induced cardiac fibrosis in rats. Hyperiension 1995;26:971-978.

10. Martorana P, Kettenbach B, Breipohl G, Linz W, Scholkens B: Reduction of infarct size by local angiotensin converting enzyme inhibition is abolished by a bradykinin antagonist. Eur $J$ Pharmacol 1990:182:395-396.

11. De Carvalho Frimm C, Sun Y, Weber KT: Wound healing following myocardial infarction in the rat: a role for bradykinin and prostaglandins. J Mol Cell Cardiol 1996;28:1279-1285.

12. Wollert KC, Studer R, Doerfer K, Schieffer E, Holubarsch C, Just H, Drexler H: Differential effects of kinins on cardiomyocyte hypertrophy and interstitial collagen matrix in the surviving myocardium after myocardial infarction in the rat. Circulation 1997:95:1910-1917.

13. Daemen MIAP. Urata H: Healing human myocardial infarction associated with increased chymase immunoreaclivity. In: Heart and vessels: Proc of the International Session at the 6Ist Annual Scientific Meeting of the Japanese Circulation Society "Circulation 97". Tokyo, Springer-Verlag. 1997, vol Suppl.12.

14. Michel JB, Lattion AL. Salzmann JL, Cerol ML, Philippe M, Camilleri JP. Corvol P: Hormonal and cardiac effects of converting enzyme inhibition in nat myocaráial infarction. Circ Res 1988:62:641-650.

15. van-Krimpen C, Schoemaker RG, Cleutjens JPM, Smits JFM, Struyker-Boudier HAJ, Bosman FT, Daemen MJAP: Angiotensin I converting enzyme inhibitors and cardiac remodeling. Basic Res Cardiol 1991;86 (Suppl. 1): $149-155$

16. Volders PGA. Willems IEMG, Cleutjons JPM, Arends JW. Havenith MG, Daemen MJAP: Interstitial collagen is increased in the noninfarcted human myocardium after myocardia! 
infarction. J Mol Cell Cardiol 1993:25:317. 323.

17. De Carvalho Frimm C, Sun Y, Weber KT: Angiotensin II receptor blockade and myocardial fibrosis of the rat heart. J Lab Clin Med 1997;129:439-446.

18. Cleutjens JPM, Verluyten MJA, Smits JFM, Daemen MJAP: Collagen remodeling after myocardial infarction in the rat heart. $\mathrm{Am} \mathrm{J}$ Pathol 1995; 147:325-338.

19. Lery BI, Benessiano J, Henrion D, Caputo L, Heymes C, Duriez M, Poitevin P, Samucl JL: Chronic blockade of AT2-subtype receptors prevents the effect of angiotensin II on rat vascular structure. J Clin Invest 1996:98:418425 .

20. Daemen MJAP, Smits JFM: The wound healing response after myocardial infarction: structural and pharmacological aspects, in Weber KT (ed): Nound healing in cardiovascular disease. New-York, Arnonk, Futura Publishing Company Inc.. 1995, pp. 23-33.

21. Anversa P, Beghi C, Kikkawa Y. Olivetti G: Myocardial response to infarction in the rat. Morphometric measurement of infaret size and myocyte cellular hypertrophy. Am J Pathol $1985 ; 118: 484-492$.

22. Anversa $P$, Sonnenblick EH: Ischemic cardiomyopathy: pathophysiologic mechanisms Prog Cardiovasc Dis 1990:33:49-70.

23. Van-Krimpen C. Smits JF, Cleutjens JP, Debets JJ. Schoemaker RG. Struyker-Boudier HA, Bosman FT, Daemen MJ: DNA synthesis in the non-infarcted eardiac interstitium after left coronary artery ligation in the rat: effects of captopril. J Mol Cell Cardiol 1991;23:12451253.

24. Weber KT: Cardiac interstitium in health and disease: the fibrillar collagen network. $J . \mathrm{Am}$ Coll Cardiol 1989:13:1637-1652.

25. Schoemaker RG, Debets JJ. Struyker-Boudier HA, Smits JF: Delayed but not immediate captopril therapy improves cardiac function in conscious rats following myocardial infarction. JMol Cell Cardiol 1991;23:187-197.

26. Capasso JM, Li P, Meggs LG, Herman MV, Anversa P: Efficacy of angiotensin-converting enzyme inhibition and ATl receptor blockade on cardiac pump performance after myocardial infarction in rats. $J$ Cardiovase Pharmacol $1994 ; 23: 584-593$.

27. Pfeffer IM, Fischer TA, Pfeffer MA: Angiotensin-converting enzyme inhibition and ventricular remodeling after myocardial infarction. Ann Rev Physiol 1995;57:805-826.

28. Macari D, Whitebread S, Cumin F, De Gasparo M, Levens N: Renal actions of the AT2 receptor ligands CGP 42112 and PD 123319 after blockade of the renin-angiotensin system. Eur $J$ Pharmacol 1994:259:27-36.

29. Keiser JA. Panek RL: Pharmacology of AT2 receptors, in Saavedra JM, Timmermans PBMWM (eds): Angiotensin Receptors. New York, Plenum Press, 1994, pp. 135-149.

30. Wallenstein S, Zucker CL. Fleiss JL: Some statistical methods useful in circulation research. Circ Res 1980,47:1-9.

31. Sechi LA. Griffin CA. Grady EF, Kalinyak JE. Schambelan $M$ : Characterization of angiotensin II receptor subtypes in rat heart. Circ Res 1992:71:1482-1489.

32. Suzuki J, Matsubara H, Urakami M, Inada M Rat angiotensin II (type lA) receptor mRNA regulation and subtype expression in myocardial growth and hypertrophy. Circ Res 1993;73:439447.

33. Chang RS, Lotti VJ: Angiotensin receptor sublypes in rat, rabbit and monkey tissues: Relative distribution and species dependency. Life Sci 1991:49:1485-1490.

34. Lopez JJ, Lorell BH, Ingelfinger JR, Weinberg EO. Schunkert H. Diamant D. Tang S-S: Distribution and function of cardiac angiotensin AT1-and AT2-receptor subtypes in hypertrophied rat hearts. Am J Physiol 1994:267:H844-H852 
35. Regitz-Zagrosek V. Fricdel N. Heymann A, Baucr P. Ncuss M. Rolfs A. Steffen C. Hildcbrandt A. Het/ar R. Flcck E: Regulation. chamber localization. and subtype distribution of angiotensin II receptors in human hearts. Circulation 1995:91:1461-1471.

36. Asano K, Dutcher DL, Port JD. Minobe WA. Trcmmel KD. Roden RL, Bohlmeycr TJ, Bush EW. Jenkin MJ. Abraham WT, Ruynolds MV. Zisman LS. Perryman MB. Bristow MR Selcctive downregulation of the angiotensin II AT l-reccptor subtype in failing human ventricular myocardium. Circulation 1997:95:1193-1200

37. Haywood GA. Gullestad L, Katsuya T, Hutchinson HG. Pratt RE. Horiuchi M. Fowler MB: AT 1 and AT2 angiotensin receptor gene expression in human hear failure. Circulation 1997:95:1201-1206.

38. Rogg H. de Gasparo M. Graedel E. Stulz P. Burkart F, Eberhard M, Erne P: Angiotensin IIreceptor subtypes in human atria and evidence for alterations in patients with cardiac disfunction. Fur Heart J 1996:17:1112-1120.

39. Sadoshima J. Lzuno S: Molecular characterization of angiolensin II-induced hypertrophy of cardiac myocytes and hyperplasia of cardiac fibroblasts. Critical role of the ATI reccptor subtype. Cin Re's 1993:73:413-423.

40. Stoll M. Stcckclings M, Paul M, Bottari SP, Met/ger R, Unger T: The angiotensin A'T2receptor mediates inhibition of cell proliferation in coronary endothelial cells. $J$ Clin Imest 1995:95:651-657.

41. Booz GW. Baker KM: Role of type I and type 2 angiotensin receptors in angiotensin II-induced cardiomyoctitc lypertrophy. Hypertension 1996:28:635-640.

42. Nakajina M. Hutchinson HG. Fujinaga M. Hayashida W. Morishita R. Zliang L. Horiuchi M, Pratt RE. Dzau VJ: The angiotensin II type 2 (AT2) receptor antagonizes the growth efects of the AT 1 receptor: gain-of-function study using gene transfer. Proc Natl Acad Sci USA 1995:92:10663-10667.

43. Grady EF, Sechi LA, Griffin CA, Schambelan M, Kalinyak JE: Expression of AT2 receptors in the developing rat fetus. $J$ Clin Invest 1991;88:921-933.

44. Iwai N, Shimoike H. Kinoshita M: Cardiac renin angiotensin system in the hypertrophied heart. Circulation 1995:92:2690-2696.

45. Pienzzi F, Abassi ZA, Keiser HR: Expression of renin angiotensin system components in the heart, kidneys, and lungs of rats with experimental heart failure. Circulation 1995;92:3105-3112.

46. Zhou J, Emsberger P. Douglas JG: A novel angiotensin receptor subtype in rat mesangium Coupling to adenylyl cyclase. Hypertension 1993;21:1035-1038.

47. de Gasparo M, Bottari S. Levens NR: Characteristics of angiotensin II receptors and their role in cell and organ physiology, in Laragh JH. Brenner BM (ects): Mypertension: pathophysioiogy. duagnosis and management, second ed. New York. Raven. Pressi Lid., 1995, pp. 1695-1720.

48. Schieffer B. Wirger A, Meybrunn M, Seitz S, Holz J, Riede UN, Drexler H: Comparative effects of chronic angiotensin-converting enzyme inhibition and angiolensin II type 1 receptor blockade on cardiac remodeling after myocardial infarction in the rat. Circulation 1994:89:2273-2282.

49. Anversa P, Beghi C. Kikkawa Y. Olivetu G: Myocardial infarction in rats. Infarct size. myocyte hypertrophy and capillary growh. Circ Res 1986:58:26-37.

50. Nelissen-Vrancken HJMG, Debets JJM, Schnoeckx LHEH, Dacmen MJAP, Smits JFM: Time-related normalization of maximal coronary flow in isolated perfused hearts of rats with myocardial infarction. Circulation 1996:93:349-355.

51. Zimmermann R. Arras M. Ulmann C. Strasser 
R, Sack S, Mollnau H, Schaper J, Schaper W: Time course of mitosis and collateral growth following coronary microembolization in the porcine heart. Cell Tissue Res 1997;287:583590.
52. Pitt B, Segal R, Martinez FA. Meurers G, Cowley AJ, Thomas I, Deedwania PC. Sanvely DB, Chang PI: Randomised trial of losartan versus captopril in patients over 65 with heart failure (Evaluation of Losartan in the Elderly Study, ELITE). Lancet 1997;349:747-752. 


\section{Effects of dobutamine and milrinone on DNA syn- thesis and collagen content in the non-infarcted myocardium after left coronary artery ligation in the rat}

\section{Summary}

Cardiac remodeling of the interstitium following myocardial infarction (MI) involves increased DNA synthesis in interstitial cells and increased collagendeposition. In spite of evidence for a mediating role of the sympathetic nervous system (SNS) in interstitial remodeling, there are no data on cardiac interstitial remodeling during therapy with sympathomimetic drugs in heart failure. Therefore, in the present study the effects of dobutamine $\left(a_{1}\right.$ - and b-receptor agonist properties) and milrinone (phosphodiesterase III inhibitor) on interstitial cell DNA synthesis and collagen deposition were characterized in rats following MI. MI was induced by ligation of the left anterior descending coronary artery in normotensive adult male Wistar rats. Sham-operated and MI rats were treated with dobutamine (l mg/kg.day, $n=7-8$ ), milrinone (150 $\mu \mathrm{g} k \mathrm{~kg}, n=3-8)$, or saline $(n=14-15)$ during the first 14 days after infarct induction. During the last 7 days, 5-Bromo-2'-deoxyUridine (Brd(J) was infused to label DNA-synthesizing cells, which was assessed immunohistochemically. 
The relative collagen area of the non-infarcted left ventricle was determined morphometrically. Following infarction the incorporation of BrdU was increased in the left ventricle in untreated infarct animals as compared to untreated sham animals $(5.9 \pm 1.1$ vs. $15.9 \pm 1.4 \%)$. Dobutamine caused a significant further increase of BrdU labeling in the septum of the left ventricle $(26.4 \pm 3.1 \%)$. Milrinone did not affect BrdU incorporation following MI (18.6 3.5\%). In sham animals BrdU labeling was unaffected by either treatment (dobutamine: $7.5 \pm 1.2$; milrinone: $3.0 \pm 0.3 \%$ ) compared to saline-treated controls $(5.9 \pm 1.1 \%)$.

The collagen content was significantly increased in the left ventricle of infarct animals $(1.8 \pm 0.2 v s .3 .4 \pm 0.3 \%$; sham vs. MI). In sham animals, dobutamime treatment significantly increased the percentage of collagen in the left ventricle $(2.6 \pm 0.2 \%)$. In MI animals, it did not cause a further increase $(2.6 \pm 0.3 \%)$. Milrinone treatment did not significantly alter the left ventricular collagen content after infarction $(2.5 \pm 0.5 \%)$, as well as in sham animals $(2.7 \pm 0.3 \%)$. In conclusion, adrenergic stimulation by dobutamine after myocardial infarction further stimulated DNA synthesis. Since the increase in DNA synthesis after infarction is enhanced by dobutamine and not by milrinone. this effect may depend upon $\alpha_{1}-$, rather than $\beta$-receptor stimulation. Similarly, the dobutamineinduced collagen deposition in sham animals in the present study also may depend upon $\alpha_{1}$ adrenergic stimulation, in spite of the fact that there seems to be a dissociation between the regulation of DNA-synthesis and collagen-deposition. In MI-animals, collagen deposition may already be stimulated to its maximum.

\section{Introduction}

For many years, sympathetic stimulation of the heart during heart failure, for instance following myocardial infarction (MI), has been one of the leading paradigms for the therapy of this syndromel. Although activation of the sympathetic nervous system (SNS) is part of the neurohumoral reflex response in heart failure ${ }^{2}$, downregulation of cardiac $\beta$-adrenoceptors was thought to result in a net reduction of cardiac sympathetic support ${ }^{3}$. Prototypical drugs that have been developed in this framework are dobutamine and milrinone. Dobutamine (Dobutrex) is a synthetic sympathomimetic drug. It is a racemate; the (-) isomer is an agonist for $\alpha_{1}$-adrenergic receptors, whereas the $(+)$ isomer is a $\beta_{1}-$ and $\beta_{2}$ adrenoceptor agonist ${ }^{4}$. In humans, dobutamine increases cardiac output and 
myocardial blood flow with relatively little effect on heart rate and blood pressure $^{5}$. Major drawbacks of this drug are the requirement for intravenous administration and, more importantly, the $\beta$-adrenoceptor downregulation that occurs during long term administration.

To circumvent these problems, phosphodiesterase III inhibitors were developed for the therapy of heart failure. The prototype for this class of drugs is the orally active bipyridine milrinone ${ }^{6}$. Phosphodiesterase III inhibition results in inhibition of the degradation of the second messenger cyclic adenosine monophosphate $(\mathrm{cAMP})^{7}$, thereby mimicking $\beta$-adrenoceptor stimulation in a non- $\beta$-adrenoceptor mediated fashion. In patients, similarly to dobutamine, milrinone elevates cardiac output; in contrast to dobutamine, it reduces blood pressure.

The response to MI not only involves a functional adaptation of the circulation, but also structural changes of the heart (cardiac remodeling) ${ }^{8}$. Cardiac remodeling involves not only cardiomyocytes", but also the cardiac interstitium, including increased DNA synthesis in interstitial cells ${ }^{10}$ and increased collagen deposition $^{1-13}$. The SNS has been implicated in both cardiomyocyte and interstitial remodeling. Results from in vivo studies indicate a mediating role of both $\alpha_{1}$ - and $\beta$-adrenoceptors in cardiac hypertrophy ${ }^{14}$. Also, in neonatal as well as in adult cultured cardiomyocytes, a growth-promoting effect through $\alpha_{1}$ - and $\beta$ adrenoceptors has been demonstrated ${ }^{15-18}$. The SNS has been implicated in cardiac structural alterations in the non-myocyte compartment like interstitial fibrosis $^{19-23}$, interstitial cell DNA synthesis ${ }^{22,23}$ and capillary growth ${ }^{24-26}$.

In spite of the evidence for the effects of adrenergic stimulation on interstitial structure, there are no data on cardiac interstitial remodeling during therapy with sympathomimetic drugs during heart failure. Therefore, in the present study the effects of dobutamine and milrinone on interstitial cell DNA synthesis and collagen deposition were characterized in rats following MI.

\section{Materials and methods}

For materials and methods used for coronary artery ligation, visualization of BrdU labeled nuclei, determination of the BrdU labeling fraction, and determination of BrdU labeled nuclei of endothelial cells, see chapter 2. 
- Animals

Normotensive adult male Wistar rats (Winkelmann, Borchen, Germany), weighing 270-320 gram at the time of surgery, were used.

\subsection{Drug treatment}

Sham-operated and MI rats were randomly assigned to groups treated with dobutamine (Dobutrex, Eli Lilly, Amsterdam, The Netherlands; $n=7-8$ ), milrinone (Sterling Winthrop, Haarlem, The Netherlands, $n=3-8)$, or $0.9 \% \mathrm{NaCl}(n=14-15)$. Drugs were dissolved in $0.9 \% \mathrm{NaCl}$. Dobutamine treatment consisted of two daily i.p. injections of $1 \mathrm{mg} / \mathrm{kg}$ (injected volume $0.3 \mathrm{ml}$ ); milrinone (150 $\mu \mathrm{g} / \mathrm{kg} . \mathrm{hr}$ ) was administered by subcutaneously implanted osmotic minipumps (ALZET 2001, Alza Corp., Palo Alto, CA, USA). Treatınents started immediately after surgery and were continued during the first 14 days after surgery. Milrinonepumps were replaced after 7 days under ether anesthesia.

\subsection{In vivo labeling of DNA synthesizing cells}

Starting 7 days before animals were sacrificed, 5-Bromo-2'-deoxyUridine (BrdU, Serva, Heidelberg, Germany; infusion rate of $2,3 \mathrm{mg} / \mathrm{kg} /$ day), a thymidine analogue which labels DNA-synthesizing cells, was given via a separate osmotic minipump (ALZET 2001, Alza Corp., Palo Alto, CA, USA), implanted subcutaneously between the shoulder blades under ether anesthesia.

\subsection{Tissue processing}

14 Days after infarct-induction or sham surgery the animals were killed in ether anesthesia. The heart was arrested in diastole by injecting $1 \mathrm{ml} \mathrm{KCl}(1 \mathrm{~mol} / \mathrm{l})$ into the inferior caval vein, and further processed, as described in chapter 2.

\subsection{Infarct size measurement}

For determination of infarct sizes, $4 \mu \mathrm{m}$ sections from 4 transverse slices were stained with the AZAN technique. Infarct sizes were measured by morphometry (Quantimet 570, Leica, The Netherlands) and determined as a percentage of the circumference of the left ventricle ${ }^{27}$.

\subsection{Determination of the BrdU labeling fraction}

For determination of the total BrdU labeling fraction, see materials and methods in chapter 2. The investigator was blinded to the treatment protocol. 


\subsection{Identification of DNA synthesizing endothelial cells}

In dobutamine-treated MI-animals the fraction of endothelial nuclei within the population of BrdU positive nuclei was determined, by the double staining method GSI-BrdU, as described in chapter 2.

\subsection{Determination of collagen protein content}

$6 \mu \mathrm{m}$ Sections were stained for collagen by incubation in $0.2 \%$ ( $\mathrm{wt}$ vol ) aqueous phosphomolybdic acid ${ }^{28}$ during 5 minutes, followed by incubation in $0.1 \%$ Sirius red F3BA (Polysciences, Northampton, UK) in saturated picric acid ( 90 minutes). Sections were washed in $0.01 \mathrm{~N} \mathrm{HCl}$ (2 minutes), cleared and mounted. The relative collagen area of the non-infarcted ventricle, i.e. the percentage of total measured area that stained positive for Sirius red, was determined under a inicroscope coupled to a computerized morphometry system (Quantimet 57(), Leica, The Netherlands). Six fields (magnification 250x) per tissue slide were analyzed in the central area of the septum. Of every cardiac slice one section was analyzed. Measurements were restricted to the interstitial collagen. Perivascular collagen was not included in the measurements.

\subsection{Statistics}

Data are expressed as mean \pm SEM. Groups were compared by one way analysis of variance (ANOVA) and a Bonferroni modified t-test, if differences existed between the groups. The level of statistical significance was assumed to be at $\mathrm{P}<0.05$.

\section{Results}

\subsection{General characteristics of the groups}

Table 1 summarizes the characteristics of the experimental groups. Starting body weights were slightly lower in dobutamine-treated sham animals than in the other groups. Induction of myocardial infarction significantly $(\mathrm{P}<0.05)$ reduced the gain in body weight seen in non-infarcted animals ( $4 \pm 5 \mathrm{vs} .19 \pm 4 \mathrm{~g}$; in $\mathrm{MI}$ and sham rats). Dobutamine-treatment increased the gain in body weight ( $28 \pm 5$ and $30 \pm 7$ grams in MI and sham rats), although statistical significance was achieved only in the MI-group. Milrinone did not affect the weight of the animals (Table 1).

Infarcts in the milrinone-group were significantly larger $(53 \pm 2 \%)$ than in the saline- $(44 \pm 2 \%)$ and dobutamine-treated $(40 \pm 4 \%)$ groups. In spite of this, 
ventricular weights were comparable in the groups, and ventricular weight to body weight ratio was even slightly, although not statistically significant, greater in the milrinone-treated MI group than in the other two MI groups.

MI increased lung weight $(2.21 \pm 0.24 \mathrm{~g})$ as compared to sham surgery ( $1.64 \pm$ 0.06 ; $\mathrm{P}<0.05$ ), suggesting pulmonary congestion due to heart failure. Neither in sham-operated, nor in $\mathrm{MI}$ rats did treatment with dobutamine or milrinone affect pulmonary weight, as compared to their respective saline-infused controls.

Table 1: General characteristics of the animal groups. Rats treated with dobutamine (Dob) or milrinone (Mil) 14 days after surgery. $M I=$ myocardial infarction; Sham = sham operated animals.

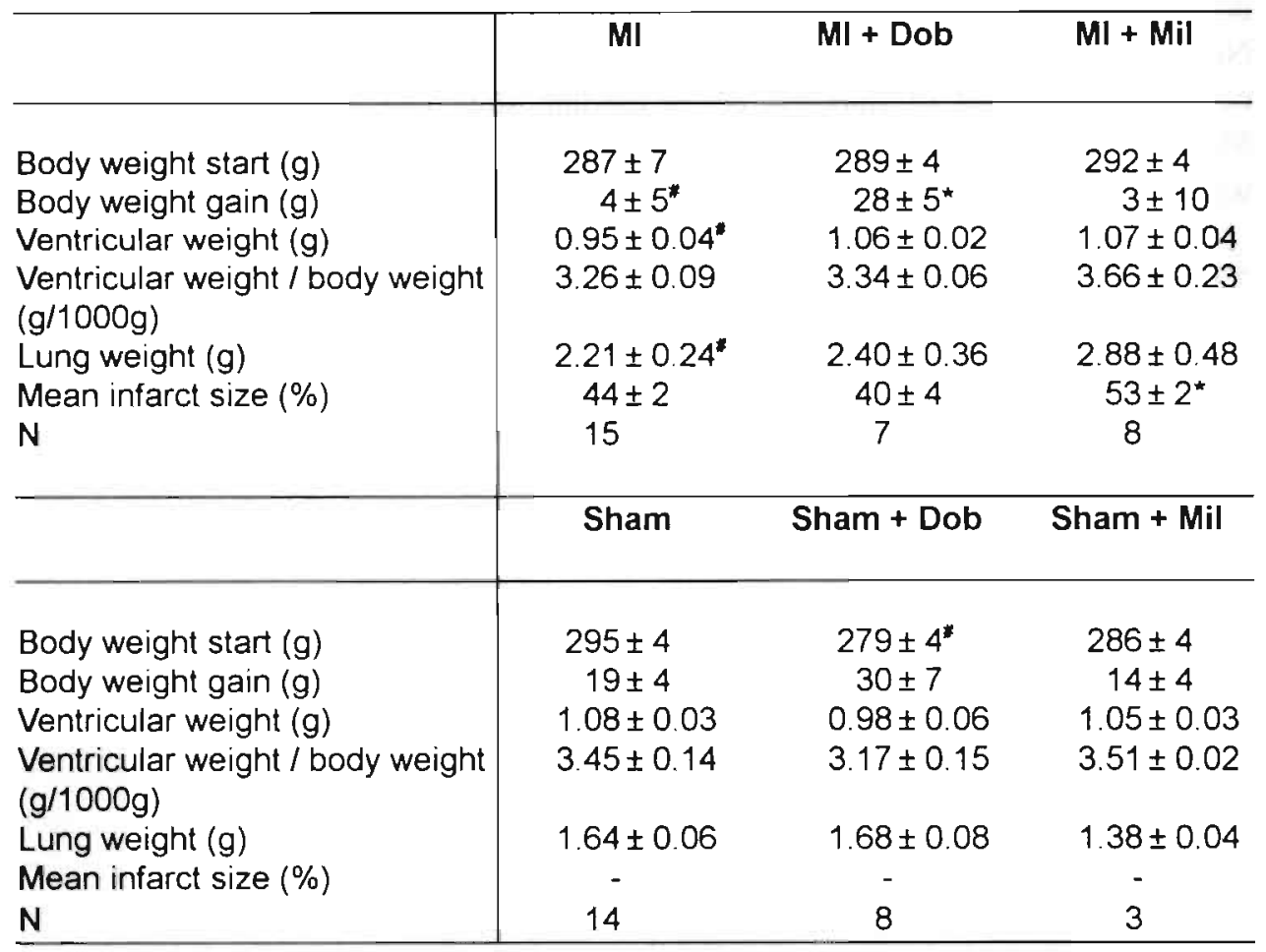

\footnotetext{
"vs. Sham

vs. MI

$\mathrm{P}<0.05$
} 


\subsection{Cardiac interstitial DNA synthesis}

Figure 1 shows the results of BrdU labeling studies in dobutamine- and milrinonetreated animals. Following infarction the incorporation of BrdU was increased in the left ventricle in untreated infarct animals as compared to untreated sham animals (see chapter 2; $5.9 \pm 1.1$ vs. $15.9 \pm 1.4 \%$ ). Dobutamine caused a significant further increase of BrdU labeling in the septum of the left ventricle $(26.4 \pm 3.1$ vs. $15.9 \pm 1.4 \%$; $\mathrm{MI}+$ dobutamine vs. MI). Milrinone did not affect BrdU incorporation following MI (18.6 $\pm 3.5 \%)$. In sham animals BrdU labeling was unaffected by either treatment (dobutamine: $7.5 \pm 1.2$; milrinone: $3.0 \pm 0.3 \%$ ) compared to saline-treated controls $(5.9 \pm 1.1 \%)$.

To investigate whether dobutamine in MI-animals caused a selective increase in endothelial cells or fibroblasts, sections were stained with both the monoclonal anti-BrdU antibody and the lectin Griffonia Simplicifolia I (see chapter 2). In untreated animals, $33 \pm 3 \%$ of BrdU-positive cells could thus be identified as endothelial cells (see chapter 2). In dobutamine-treated animals, this fraction was not affected $(30.4 \pm 3.1 \%)$, indicating that the increase in DNA synthesis occurred to a similar extent in endothelial cells and fibroblasts.

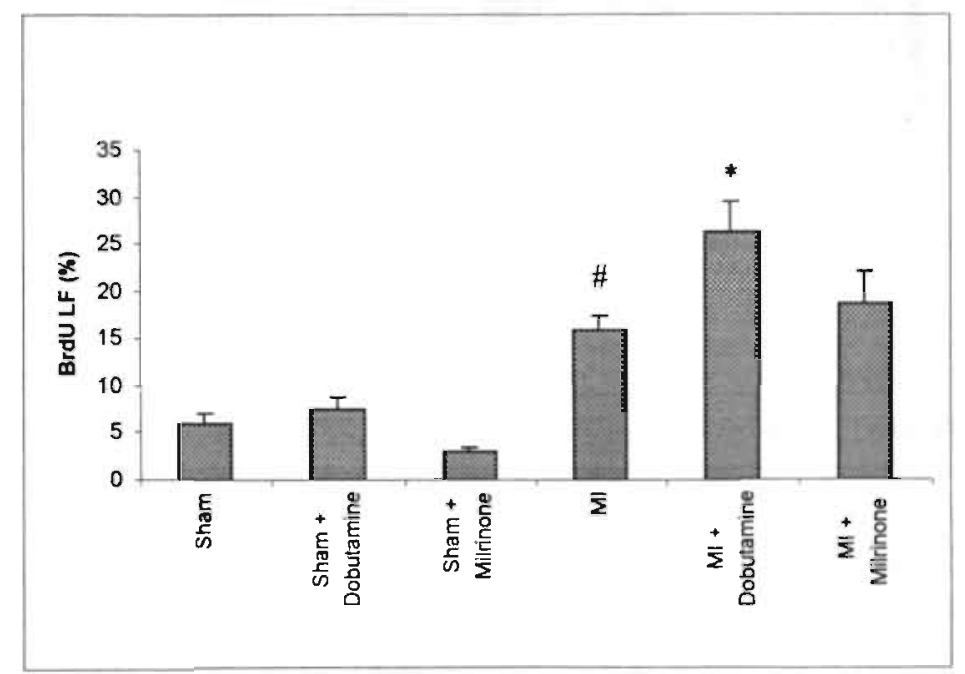

Figure 1: BrdU labeling fractions (LF\%) in the septal region of the left ventricle $1+$ days after myocardial infarction and effects of dobutamine and milrinone. Sham = non-treated sham-operated animal. $M I=$ nontreated infarct animals.

"vs. Sham

* vs. $M I$ 


\subsection{Cardiac collagen content}

Figure 2 shows results of collagen measurements. The percentage Sirius red positive area, reflecting collagen content, was significantly increased in the left ventricle of infarct animals ( $1.8 \pm 0.2$ vs. $3.4 \pm 0.3 \%$; sham vs. MI). In sham animals, dobutamine treatment significantly increased the percentage of collagen in the left ventricle $(2.6 \pm 0.2 \%)$. In MI animals, it did not cause a further increase $(2.6 \pm 0.3 \%)$. Milrinone treatment did not significantly alter the left ventricular collagen content after infarction $(2.5 \pm 0.5 \%)$, as well as in sham animals $(2.7 \pm 0.3 \%)$.

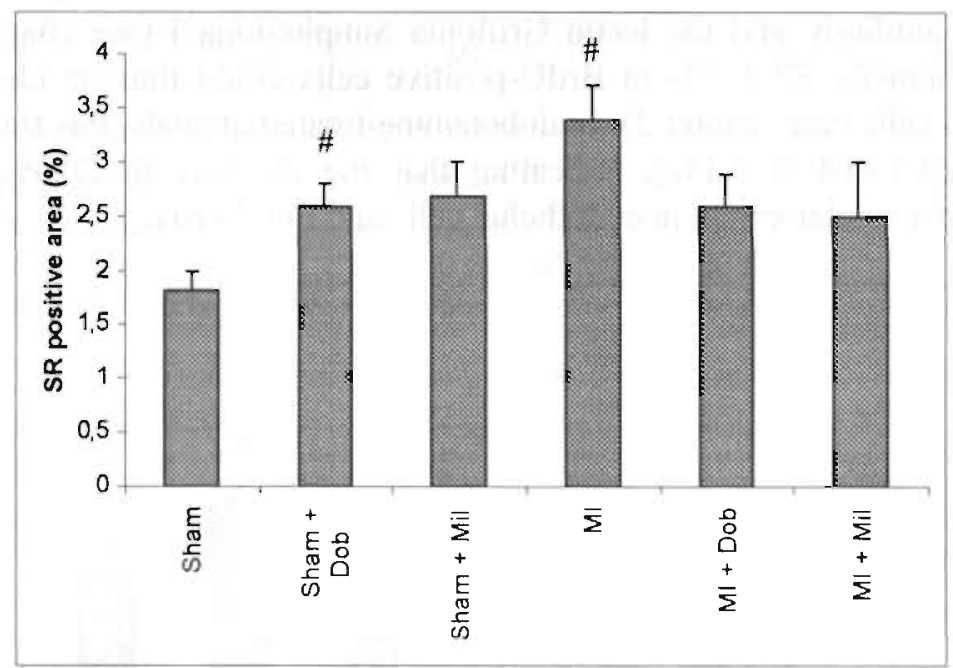

Figure 2: Sirius red (SR) positive area (\%) in the septal region of the left ventricle 14 days after myocardial infarction and effects of dobutamine and milrinone. Sham = non-treated sham-operated animal. $M I=$ nontreated infarct animals.

"vs. Sham 


\section{Discussion}

In the present study, the effects of sympathomimetics on cardiac DNA synthesis and collagen deposition were studied following MI in rats. This was achieved through twice daily injections of dobutamine, a synthetic receptor agonist with $\alpha_{1}$ and $\beta$-receptor agonist properties, or infusion of the phosphodiesterase III inhibitor milrinone. Protocols and dosages were chosen on the basis of previous hemodynamic studies, in which these drugs were found to improve cardiac function $^{29.30}$.

The findings in the present study confirm and extend previous results, indicating that the cardiac collagen content increases early after myocardial infarction ${ }^{10,11}$. Sympathetic stimulation with dobutamine or phosphodiesterase III inhibition with milrinone has divergent effects on DNA synthesis after infarction. While dobutamine increased DNA synthesis to even higher levels, milrinone did not affect this parameter after infarction. Both agents failed to elevate the collagen content in infarcted animals. In contrast, in sham animals dobutamine did elevate the collagen concentration in the heart, without affecting DNA synthesis. Milrinone, again, had no significant effects on these parameters. Taken together, these findings indicate i) a dissociation of the regulation of DNA synthesis and collagen content after myocardial infarction; ii) dissociation of the effects of dobutamine in infarcted and sham-operated animals; iii) a dissociation of the effects of adrenergic receptor stimulation with dobutamine and phosphodiesterase III inhibition on DNA synthesis.

The data indicate divergence of the regulation of interstitial DNA synthesis and collagen synthesis, since dobutamine further increased DNA synthesis, but not collagen content after myocardial infarction. Such divergent effects on DNA synthesis and collagen after MI have also been found in previous studies from our laboratory. ACE-inhibition inhibited both parameters in $\mathrm{MI}$ animals, whereas the $\mathrm{AT}_{1}$-receptor antagonist losartan decreased collagen deposition to sham levels, and only partially inhibited DNA synthesis ${ }^{\prime \prime} ; \mathrm{AT}_{2}{ }_{2}$ antagonisin showed divergent effects in the opposite direction with inhibition of DNA synthesis (chapter 4), and no effects on the post-infarction collagen content (M. Daemen en J. Smits, unpublished observation). Obviously, this might derive from the fact that proliferating interstitial cells comprise not only fibrillar collagen synthesizing fibroblasts, but also endothelial cells (chapter 2), and that proliferation of both 
cell types may be regulated differentially. However, quantification of the percentage of endothelial cells within the BrdU-positive cell population indicated no differences between untreated and dobutamine-treated animals.

Likewise, others have noted similar divergences in a model of vascular injury ${ }^{31}$ and in cultured mesangial cells ${ }^{32}$. In human atherosclerotic plaques, both PCNApositive and collagen synthesizing cells were observed, but coincidence of these two phenomena within the same cells occurred rarely ${ }^{33}$. Thus, cell DNA synthesis and collagen deposition should be considered independent processes.

Administration of dobutamine increased the amount of myocardial collagen in sham animals, but not in MI animals. A possible role for sympathetic stimulation in collagen metabolism has been reported in several studies. Administration of norepinephrine, which stimulates both $\alpha$ - and $\beta$-receptors, significantly increased the amount of mRNA for collagen $I$ in the normal rat heart ${ }^{19}$. Augmentation of cardiac collagen content by $\beta$-adrenergic stimulation in the rat has been well documented ${ }^{20-22}$. Furthermore, a stimulatory role of the $\alpha_{1}$-adrenergic agonist phenylephrine on cardiac fibrosis has also been reported ${ }^{23}$. Thus, both $\beta$ - and $\alpha_{1}$ adrenergic effects of dobutamine might be responsible for the observed increase in collagen content in sham animals. Since milrinone, which activates $\beta$-but not $\alpha$-adrenoceptor pathways, did not significantly affect the amount of collagen in sham animals, the data would suggest a role for $\alpha_{1}$-adrenoceptors in the regulation of collagen metabolism in sham animals. The lack of effect of adrenergic stimulation on collagen following infarction could indicate that the sympathetic component in the regulation of collagen deposition is already maximally stimulated in this condition.

The effect of dobutamine on post-infarction DNA synthesis in the present study could, again, be mediated by $\beta$ - and/or $\alpha_{1}$-adrenergic receptors. In the rat heart, in vivo, both the $\beta$-adrenergic agent isoproterenol ${ }^{22}$ and the $\alpha_{1}$-adrenergic agent phenylephrine ${ }^{2.3}$ have been reported to stimulate DNA synthesis in non-myocyte cells. Also in vitro, norepinephrine ${ }^{19}$ and selective $\beta$-adrenergic stimulation ${ }^{34}$ have been shown to be mitogenic for cultured cardiac fibroblasts. A recent study showed inhibition of proliferation in $3 \mathrm{~T} 3$ cells in culture by cyclic $\mathrm{AMP}^{35}$. Similarly, increased levels of cyclic AMP caused suppression of angiogenesis in the chick chorioallantoic membrane system (CAM) and in human umbilical venous endothelial cells (HUVEC) ${ }^{30}$. In the present study, the complete lack of effect of milrinone suggests again a primary role for the $\alpha_{1}$-receptor. This is 
consistent with the notion that in heart failure, in view of the $\beta$-receptor desensitization (vide supra), the $\alpha_{1}$-adrenoceptor may become more important ${ }^{37}$.

Cardiac interstitial effects could also depend on mechanical factors. Inotropic stimulation has been hypothesized as a primary responsible mechanism in a study by Brown et al. ${ }^{26}$, in which chronic intermittent dobutamine treatment increased interstitial capillary growth in rabbit hearts. Our observation that dobutamine increases DNA synthesis in endothelial cells is consistent with increased capillary growth. Since milrinone also has been reported to act as an inotropic agent in chronically infarcted hearts ${ }^{7.29 .38 .39}$, the divergence between the effects of milrinone and of dobutamine after infarction seems not to depend upon inotropy. Local cardiac mechanics could also be affected by dilatation. In this respect, dobutamine and milrinone can act differently. Consistently, milrinone treated animals had larger infarct measurements than dobutamine treated animals, in spite of random assignment of MI-animals to either treatment groups. Infarct elongation could depend upon the presence of myofibroblasts in the infarct ${ }^{40,41}$. These cells exhibit vascular smooth muscle-like properties ${ }^{42}$. Similar to vascular preparations, milrinone was found to relax isolated infarcts from rat hearts (J. De Mey, personal communication). Differences in wall stress, resulting from the different ventricular diameters of dobutamine and milrinone treated animals may thus have contributed to the observed differences between the two drugs. However, the observed effects in the present study differ from what one would anticipate in this context (i.e. an increase in wall stress associated with an increase in DNA synthesis), making this explanation less likely.

In conclusion, adrenergic stimulation by dobutamine after myocardial infarction affects the structure of the cardiac interstitium through further stimulation of DNA synthesis. Since the increase in DNA synthesis after infarction is enhanced by dobutamine and not by milrinone, this effect may depend upon $\alpha_{1}-$, rather than $\beta$ receptor stimulation. Similarly, the dobutamine-induced collagen deposition in sham animals in the present study also may depend upon $\alpha_{1}$-adrenergic stimulation, in spite of the fact that there seems to be a dissociation between the regulation of DNA synthesis and collagen deposition. In MI-animals, collagen deposition may already be stimulated to its maximum. 


\section{References}

1. Packer M: Role of the sympathetic nervous system in chronic hear failure. A historical and philosophical perspective. Circulation 1990;82(Suppl.):I1-I6.

2. Remme WJ: Congestive heart failurepathophysiology and medical treatment. $J$ Cardiovasc Pharmacol 1986;8 (Suppl.1):S36S52.

3. Bristow MR, Ginsburg R. Minobe W, Cibiccioti RS, Sageman WS, Luric K. Billingham ME, Harrison DC. Stinson EB: Decreased catecholamine sensilivity and beta-adrenergic density in failing human hearts. $N$ Engl IJ Med 1982:307:205-211.

4. Ruffolo RR: The pharmacology of dobutamine. Am JMed Sci 1987;294:244-248.

5. Tuttle RR, Mills J: Dobutamine-development of a new catecholamine to selectively increase cardiac contractility. Circ Res 1975:36:185-196.

6. Alousi AA. Canter JM. Montenaro MJ. Fort DJ. Ferrari RA: Cardiotonic activity of milrinone. a new potent cardiac bipyridine, on the normal and failing heart of experimental animals. $J$ Cardiovasc Pharmacol 1983:5:792-803.

7. Earl CQ, Linden J, Weglicki WB: Biochemical mechanisms for the inotropic effect of the cardiotonic drug milrinone. $J$ Cardiovase Pharmacol 1986:8:864-872.

8. Daemen MJAP. Smits JFM: The wound healing response after myocardial infarction: structural and pharmacological aspects, in Weber KT (ed): Hewnd healing in cardiovascular disease. New-York, Arnonk, Futura Publishing Company Inc., 1995, pp. 23-33.

9. Anversa P. Loud AV, Levicky V, Guideri G: Left ventricular failure induced by myocardial infaretion. 1. Myocyte hypertrophy. Am J Physiol 1985:248:H876-H882.

10. Van-Krimpen C, Smits JF, Cleutjens JP, Debets Jj. Schoemaker RG. Stnuyker-Boudier HA.
Bosman FT, Daemen MJ: DNA syuthesis in the non-infarcted cardiac interstitium after left coronary artery ligation in the rat: effects of capiopril. JMol Cell Cardial 1991:23: 12451253.

11. Smits JFM, Van Krimpen C, Schoemaker RG, Cleutjens JPM, Daemen MJAP: Angiotensin II receptor blockade after myocardial infarction in rats: effects on hemodynamics, myocardial DNA synthesis and interstitial collagen content. $J$ Cardiovase P'harmacol 1992:20:772-778.

12. Volders PGA, Willems IEMG. Cleutjens JPM, Arends JW, Havenith MG, Daemen MJAP: Interstitial collagen is increased in the noninfarcted human myocardium after myocardial infaretion. J Mo/ Cel/ Carliol 1993:25:3 17323.

13. Michel JB. Lattion AL, Salzmann JL. Cerol ML. Philippe M. Camilteri JP. Corvol P: Hormonal and cardiac effects of converting enzyme inhibition in rat myocardial infarction. Cinc Res 1988:62:641-650.

14. Zierhut W, Zimmer HG: Significance of myocardial alpha- and beta-adrenoceptors in catecholamine-induced cardiac hypertroplyy. Circ Res 1989:65:1417-1425.

15. Simpson P: Stimulation of hypertrophy of cultured neonatal rat heart cells through an alpha 1-adrenergic receptor and induction of beating through an alpha $\mathrm{l}$ - and beta $\mathrm{l}$ adrenergic receptor interaction. Evidence for independent regulation of growth and beating. Circ Res 1985:56:884-894.

16. Schlucter K-D, Piper HM: Trophic effects of catecholamines and parathyroid hormone on adult ventricular cardiomyocytes. A $\mathrm{m} J$ Physiol 1992;236:H1739-H1746.

17. Yamazaki T, Komuro I, Zou Y, Kudoh S. Shiojima I, Hiroi Y. Mizuno T, Aikawa R. Takano H. Yazaki Y: Norepinephrine induces the raf-1 kinase/mitogen-activated protein cascade through both alpha l- and beta- 
adrenoceptors. Circulation 1997;95:1260-1268.

18. Zhou XJ, Schlueter K-D. Piper HM: Hypertrophic responsiveness of beta2adrenoceptor stimulation on adult ventricular cardiomyocytes. Mol Cell Biochem $1996 ; 163 / 164: 211-216$.

19. Bhambi B, Eghbali M: Effect of norepinephrine on myocardial collagen gene expression and response of cardiac fibroblasts after norepincphrine treatment. $A m J$ Pathol 1991;139:1131-1141.

20. Jalil JE. Janicki JS, Pick R, Abrahams C, Weber $\mathrm{KT}$ : Fibrosis-induced reduction of endomyocardium in the rat after isoproterenol treatment. Circ Res 1989:65:258-264.

21. Pick R, Jalil JE, Janicki JS, Weber KT: The fibrillar nature and structure of isoproterenolinduced myocardial fibrosis in the rat. $A \mathrm{~m} \mathrm{~J}$ Pathol 1989;134:365-371.

22. Benjamin IJ. Jalil JE. Tan LB. Cho K. Wether KT. Clark WA: Isoproterenol-induced nyocardial fibrosis in relation to myocyte necrosis. Circ Res 1989:65:657-670.

23. Farivar RS. Crawford DC. Chobanian AV. Brecher P: Effect of angiotensin II blockade on the fibroproliferative response to phenylephrine in the rat heart. Hypertension 1995:25:809-813.

24. Tomanck RJ: Sympathetic nerves modify mitochondrial and capillary growth in normotensive and hypertensive rats. $J \mathrm{Mol} \mathrm{Cell}$ Cardiol 1989:21:755-764.

25. Torry RJ. Connell PM. O'Bricn DM. Clilian WM. Tomanck RJ: Sympathectomy stimulates capillary but not precapillary growih in lipertrophic hearts. A $m J$ Phisiol 1991;260:H1515-H152 I

26. Brown MD. Hudlicka O: Capillary supply and cardiac performance in the rabbil after chronic dobutamine treatment. Cardiovasc Res 1991;25:909-915.

27. Fislbein MC, Maclean D. Maroko PR: Experimental myocardial infarction in the rat.
Am .I Pathol 1978;90:57-70.

28. Dolher PC, Spach MS: Picrosirius red staining of cardiac muscle following phosphomolybdic acid treatment. Stain Technol 1987:62:23-26.

29. Schoemaker RG. Debets JIM. Struyker-Boudier HAJ, Smits JFM: Beneficial hemodynamic effects of two weeks' milrinone treatment in conscious rats with heart failure. Eur.J Pharmacol 1990:182:527-535.

30. Schoemaker RG. Debets JJM, Struyker-Boudier HAJ, Smits JFM: Two weeks of iniermittent dobutamine therapy restores cardiac performance and inotropic responsiveness in conscious rats with heart failure. $J$ Cardiovase Pharmacol 1991:17:949-956.

31. Plissonnier D, Amichot $G$, Duriez $M$, Legagneux J. Lery BI. Michel J-B: Effect of converting enzyme inhibition on allograftinduced arterial wall injury and response. Hypertension 1991:18(Suppl.II):II47-II54.

32. He C-J, Striker LJ, Tsokos M, Yang C-W. Peten EP. Striker GE: Relationships between mesangial cell proliferation and types I and IV collagen mRNA levels in vitro. Am.J Physiol $1995: 269:$ C554-C562.

33. Rekhter MD. Gordon D: Cell proliferation and collagen synthesis are two independent events in human alherosclerotic plaques. $J$ lasc Res 1994:31:280-286.

34. Long CS. Hartogensis WE, Simpson PC: $\beta$ Adrenergic stimulation of cardiac non-myocytes augments the growth-promoting activity of nonmyocyte conditioned medium. J Mol Cell Cardiol 1993:25:915-925.

35. McKenzie FR. Pouyssegur J: CAMP-mediated growth inhibition in fibroblasts is not mediated via mitogen-activated protein (MAP) kinase (ERK) inlibition. $J$ Biol Chem 1996:271:13476-13483.

36. Tsopanoglou NE, Haralabopoulos GC, Maragoudakis ME: Opposing effects on modulation of angiogenesis by protein kinase $\mathrm{C}$ and CAMP-mediated pathways. J Vasc Res 


\section{Chapter 5}

\section{4:31:195-204.}

37. Milligan G, Svoboda P, Brown CM: Why are there so many adrenoceptor subtypes? Biochem Pharmacol 1994;48:1059-1071.

38. Schoemaker RG. Urquhart J, Debets JJM, Struyker-Boudier HAJ. Smits JFM: Cardiac function in conscious rats: acute effects of dobutamine and milrinone. in Progress in Pharmacology and Clinical Pharmacology., Gustav Fischer Verlag-Stuttgan-New York, 1990 , vol 7/3, pp. 37-47.

39. Katano $Y$, Endoh M: Effects of a cardiotonic quinolinone derivative $Y-20487$ on the isoproterenol-induced positive inotropic action and cyclic AMP accumulation in rat ventricular myocardium: comparison with rolipram. Ro 20-
1724. milnnone. and isobuly/methylxanthine. $J$ Cardiovax l'harmacol 1992:20:715-722.

40. Willems IEMG, Havenith MH. De Mcy JGR. Dacmen MJAP: Alpha smooth muscle actin positive cells in healing human myocardial scars. A $m$. Pathol 1994: 145:868-875.

41. Vracko $R$, Thorning D: Contractile cells in rat myocardial scar tissue. lah lmvest 1991:65:221227.

42. Sappino AP. Schuerch W. Gabbiani G: Differentiation repentoire of fibroblastic cells: expression of cyloskeletal proteins as a marker of phenotypic modulations. Lab Inest $1990 ; 63: 144-161$. 


\section{Effects of sympatholytic agents on DNA synthesis and collagen content in the rat heart after infarction}

\section{Summary}

Previous studies from our laboratory have shown that an increase in interstitial cell DNA synthesis and in the amount of collagen in the non-infarcted myocardium early after myocardial infarction (MI) induction are parts of the remodeling response in the rat. Sympathetic nervous system (SNS) activation following MI may contribute to these phenomena, since it has been shown to be activated in this condition and has been implicated in cardiac fibrosis and cell proliferation in several models. In the previous chapter results from experiments showed that, following MI in rats, sympathomimetic drugs did not increase the post-infarction enhanced collagen deposition, whereas dobutamine did increase collagen content in sham-operated animals. Possibly, this reflects a maximal activation of SNS-dependent control mechanisms for this process after MI. In the present study it was tested whether adrenergic blockade by means of the nonselective b-adrenergic receptor antagonist propranolol, or by means of the centrally acting sympatholytic agents clonidine or moxonidine, affects curdiac 
interstitial remodeling after $M I$ in the rat. MI was induced by ligation of the left anterior descending coronary artery in normotensive adult male Wistar rats. Sham and MI rats were treated with moxonidine (1 $\mathrm{mg} / \mathrm{kg}$. day), clonidine ( 100 $\mathrm{mg} / \mathrm{kg}$.day), propranolol (5 $\mathrm{mg} / \mathrm{kg}$.day) or saline during the first 14 days after surgery. During the last 7 days, 5-Bromo-2'-deoxyUridine (BrdU) was infused to label DNA-synthesizing cells, which was assessed immunohistochemically. The relative collagen area of the non-infarcted left ventricle was determined morphometrically. MI significantly increased interstitial cell DNA-synthesis (left ventricle; sham: $5.9 \pm 1.1 \%$ BrdU-positive cells, $n=14 ; M I ; 15.9 \pm 1.4 \%, n=15$ ) and collagen content (sham: $1.8 \pm 2 \% ;$ MI: $3.4 \pm 0.3 \%$ ). Treatment with moxonidine, clonidine or propranolol did not affect these processes. In contrast, collagen content was increased after treatment with moxonidine (left ventricle: $2.6 \pm 0.7 \% ; n=7)$, clonidine $(3.4 \pm 0.8 \% ; n=8)$ and propranolol $(3.0 \pm 0.4 \%$; $n=8)$ in sham-operated animals.

In conclusion, our data indicate that propranolol, clonidine and moxonidine increase interstitial collagen in sham-operated animals. Further studies are needed to clarify the possible stimulating role of $\alpha$-adrenergic and imidazoline receptors in this process. Sympathetic inhibition with these drugs does not affect fibrosis after infarction, possibly because of activation of the fibrotic process by other dominant systems early after MI. Similarly, interstitial cell proliferation is unaffected. Our data indicate that, in the early phase following MI, the sympathetic nervous system does not substantially contribute to interstitial remodeling.

\section{Introduction}

Following myocardial infarction (MI) several neuroendocrine systems are activated, such as the sympathetic nervous system (SNS) and the renin-angiotensinaldosterone system (RAAS) ${ }^{1.2}$. Neurohumoral activation occurs very early, probably almost immediately after an acute $\mathrm{MI}^{3}$. Acutely, these processes may contribute to maintenance of the circulation. However, an important question remains whether activation of the RAAS and SNS, as can be observed after major cardiac insults, might eventually be detrimental to the structure and function of the surviving myocardium. In this respect, studies show a significant correlation between neurohumoral activation and mortality ${ }^{2,4.5}$. Pharmacological modulation of the RAAS is now believed to be a major goal in the treatment of heart failure . $^{6}$ 
Suppression of the RAAS after acute MI, by angiotensin-converting enzyme (ACE) inhibitors, improves the long-term outcome of patients ${ }^{7.8}$. From these studies it has become clear that prevention or regression of ventricular remodeling is one of the major contributors to their favorable effects ${ }^{9.10}$. This cardiac response not only consists of left ventricular dilatation and hypertrophy ${ }^{11,12}$, but also of interstitial remodeling including cellular proliferation and collagen deposition $^{13}$. In rats, it has been observed previously that ACE-inhibition also prevents interstitial remodeling (chapter 3$)^{14}$. Interstitial remodeling appears to be associated with functional changes of the myocardium ${ }^{15-17}$.

Successful clinical trials with $\beta$-adrenergic receptor antagonists ${ }^{18-20}$ and disappointing effects of sympathomimetic agents ${ }^{21-23}$ have recently drawn attention to the SNS as an other key player in MI and heart failure ${ }^{24-26}$. However, the basis for the beneficial effects of $\beta$-blockade is still not completely understood, but might be related to the suppression and occurrence of arrhythmias, respectively ${ }^{24,26}$. Fibrosis is known to contribute to the occurrence of arrhythmias ${ }^{27}$.

Excessive activation of the SNS has been proposed to affect ventricular remodeling ${ }^{26.28}$. In several models, the SNS has similarly been implicated in cell proliferation ${ }^{29-32}$ and cardiac fibrosis ${ }^{15,29-31,33}$. In the previous chapter an increase in cardiac interstitial collagen deposition in sham-operated, but not in MI rats after treatment with the adrenergic agent dobutamine has becn observed. It was hypothesized that one possible explanation for the lack of response following MI could be that, in this condition, the sympathetic component of this process is already maximally activated.

Few data are available on effects of adrenergic blockade on the structure of surviving myocardium after MI. In the rat, following MI, propranolol blunted hypertrophy and promoted left ventricular dilatation ${ }^{34,35}$. Treatment of rats with the $\beta$-adrenoceptor antagonist metoprolol or the centrally acting sympatholytic agent CHF-1024, from 2-3 montlss after MI reduced cardiac collagen content ${ }^{36}$, which seems to corroborate our hypothesis, although a $\beta$-adrenergic component in the response was not apparent (chapter 5). No data are available on the effects of adrenergic inhibition on the cardiac interstitium shortly after MI. The purpose of the present study was to investigate if adrenergic blockade by means of propranolol, or inhibition of the SNS by the centrally acting sympatholytic agents clonidine or moxonidine, affects cardiac interstitial remodeling after myocardial infarction in the rat. 


\section{Materials and methods}

For materials and methods used for coronary artery ligation, tissue processing, infarct size measurement, visualization of BrdU labeled nuclei, determination of the BrdU labeling fraction see cliapter 2 , and for determination of collagen protein content see chapter 5 .

\section{- Animals}

Normotensive adult male Wistar rats (Winkelmann, Borchen, Gennany), weighing 275-33.1 gram at the time of surgery, were used.

\subsection{Drug treatment}

Sham and MI rats were treated with moxonidine ( $1 \mathrm{mg} / \mathrm{kg}$.day; $\mathrm{n}=7$ each), clonidine (100 mg/kg.day; $n=8$ each), propranolol (5 mg/kg.day; $n=7-8$ ) or saline $(n=14-15)$. Drugs were dissolved in normal saline and administered by subcutaneously implanted osmotic minipumps (ALZET 2001, Alza Corp., Palo Alto, CA, USA). Treatment started immediately after surgery and was continued during the first 14 days after surgery. Pumps were replaced after 7 days under ether anesthesia.

Clonidine. $\mathrm{HCl}$ and propranolol. $\mathrm{HCl}$ were purchased from Sigma Chemicals (St. Louis, Mo, ISSA). Moxonidine. $\mathrm{HCl}$ was a gift from Dr. D. Thormählen (Solvay, Hannover, (iemany). All doses are expressed on the basis of the salts.

\subsection{Statistics}

Data are expressed as mean \pm SEM. Groups were compared by one way analysis of variance (ANOVA) and a Bonferroni modified t-test, if differences existed between the groups. The level of statistical significance was assumed to be at $\mathrm{P}<$ 0.05 . 


\section{Results}

\subsection{General characteristics of the groups}

Table 1 summarizes the characteristics of the experimental groups. Infarct-sizes were similar in the MI-groups, ranging from 40 to $44 \%$ of the LV. Body weights for the groups before surgery were between 281 and 319 grams. Saline-treated MI animals gained significantly less weight ( $4 \pm 5$ grams) than sham-operated rats ( $19 \pm 4$ grams). Such differences were not observed in clonidine- or moxonidinetreated animals, which exhibited slightly increased weight gains (Table 1). Propranolol abolished weight gain in sham-operated rats $(+5 \pm 12$ grams), whereas it reduced body weight by $27 \pm 6$ grams in MI-animals.

Ventricular weight to body weight ratios were similar in all groups (Table 1). For the saline-treated MI group ( $3.26 \pm 0.09$ as compared to $3.45 \pm 0.14$ in shamoperated rats), this implies hypertrophy of the remnant myocardium, in view of the loss of $44 \%$ of their left ventricular wall. Similarity of ventricular weights also implies a lack of effect of any of the drug-treatment regimens on normal ventricular weights in shams and on the hypertrophic response following MI.

Lung weight was taken as an indicator for pulmonary congestion. Lung weights were significantly higher in all MI groups as compared to sham groups. Within the sham-operated groups, none of the drug treatments affected lung weights (Table 1). Within the MI-groups, clonidine and moxonidine had no effects on increased lung weights. Propranolol, however, caused a further increase in lung weight (3.32 \pm 0.43 grams) as compared to saline-treatment $(2.21 \pm 0.24$ grams). 
Table 1: (jeneral sharacteristus of the amimal groups. Rats treated with moxonidimo (Afox),

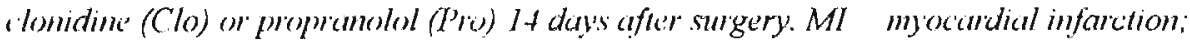
Sham = shom operated amimals.
MI
MI + Mox
$\mathrm{MI}+\mathrm{Clo}$
MI + Pro

$\begin{array}{lcccc}\text { Body weight start }(\mathrm{g}) & 287 \pm 7 & 281 \pm 4 & 287 \pm 5 & 308 \pm 3 \\ \text { Budy weight gain }(\mathrm{g}) & 4 \pm 5^{*} & 28 \pm 13 & 24 \pm 5 & -27 \pm 6 \\ \text { Ventricular weight }(\mathrm{g}) & 0.95 \pm 0.04^{*} & 1.11 \pm 0.05 & 1.03 \pm 0.04 & 1.04 \pm 0.07 \\ \text { Ventricular weight/ } & 3.26 \pm 0.09 & 3.59 \pm 0.22 & 3.32 \pm 0.12 & 3.70 \pm 0.28 \\ \text { body weight }(\mathrm{g} / 1000 \mathrm{~g}) & & & & \\ \text { Lung weight }(\mathrm{g}) & 2.21 \pm 0.24^{*} & 2.70 \pm 0.38 & 2.29 \pm 0.41 & 3.32 \pm 0.43^{*} \\ \text { Mean infarct size (\%) } & 44 \pm 2 & 44 \pm 2 & 40 \pm 2 & 40 \pm 3 \\ \mathrm{~N} & 15 & 7 & 8 & 7\end{array}$

\section{Sham Sham + Mox Sham + Clo Sham + Pro}

$\begin{array}{lcccc}\text { Body weight start }(\mathrm{g}) & 295 \pm 4 & 312 \pm 5 & 309 \pm 4 & 319 \pm 5 \\ \text { Body weight gain }(\mathrm{g}) & 19 \pm 4 & 25 \pm 7 & 20 \pm 4 & 5 \pm 12 \\ \text { Ventricular weight }(\mathrm{g}) & 1.08 \pm 0.03 & 1.14 \pm 0.04 & 1.10 \pm 0.05 & 1.02 \pm 0.03 \\ \text { Ventricular weight/ } & 3.45 \pm 0.14 & 3.38 \pm 0.11 & 3.34 \pm 0.06 & 3.14 \pm 0.31 \\ \text { body weight }(\mathrm{g} / 1000 \mathrm{~g}) & & & & \\ \text { Lung weight }(\mathrm{g}) & 1.64 \pm 0.06 & 1.51 \pm 0.11 & 1.50 \pm 0.13 & 1.33 \pm 0.17 \\ \text { Mean infarct size (\%) } & - & - & - & - \\ \mathrm{N} & 14 & 7 & 8 & 8\end{array}$

\subsection{Interstitial DNA-synthesis}

The incorporation of BrdU in the non-infareted left ventricle (cf. figure 1) was increased in saline-treated MI animals (LF: $15.9 \pm 1.4 \%$ ) as compared to untreated sham animals $(5.9 \pm 1.1 \%)$ (see chapter 2$)$. Treatment with moxonidine $(12.1 \pm$ $2.5 \%$ ), clonidine $(14.2 \pm 3.3 \%)$, nor propranolol $(13.8 \pm 2.1 \%$ ) affected this parameter. Similarly, these parameters were unaffected by treatments in shamoperated animals. 


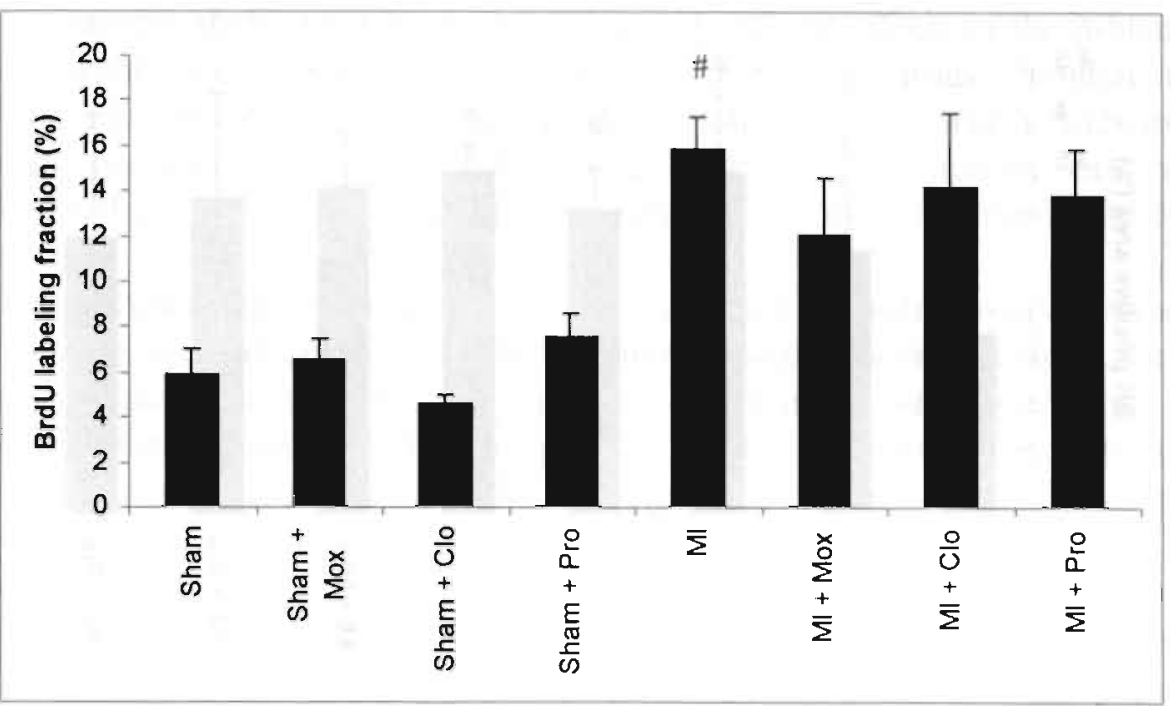

Figure 1: Effects of treatment with moxonidine (Mox), clonidine (Clo) and propranolol (Pro) on BrdU labeling fraction in the left ventricle of sham-operated (Sham) and infarcted (MI) rats.

", P. 0.05 as compared sham-eperated rats.

\subsection{Interstitial collagen concentrations}

Interstitial collagen concentrations in the different groups of animals arc shown in figure 2. Interstitial collagen increased in the non-infarcted left ventricle in infarct animals as compared to untreated sham animals (sham: $1.8 \pm 0.2 \% ; \mathrm{MI}: 3.4 \pm$ $0.3 \%$; see chapter 5). In MI-animals, treatment with moxonidine ( $3.2 \pm 0.5 \%$ ), clonidine $(3.1 \pm 1.0 \%)$ or propranolol $(2.8 \pm 1.2 \%)$ did not affect this parameter after infarction. In contrast, all three drugs significantly increased LV collagen content in sham animals. 


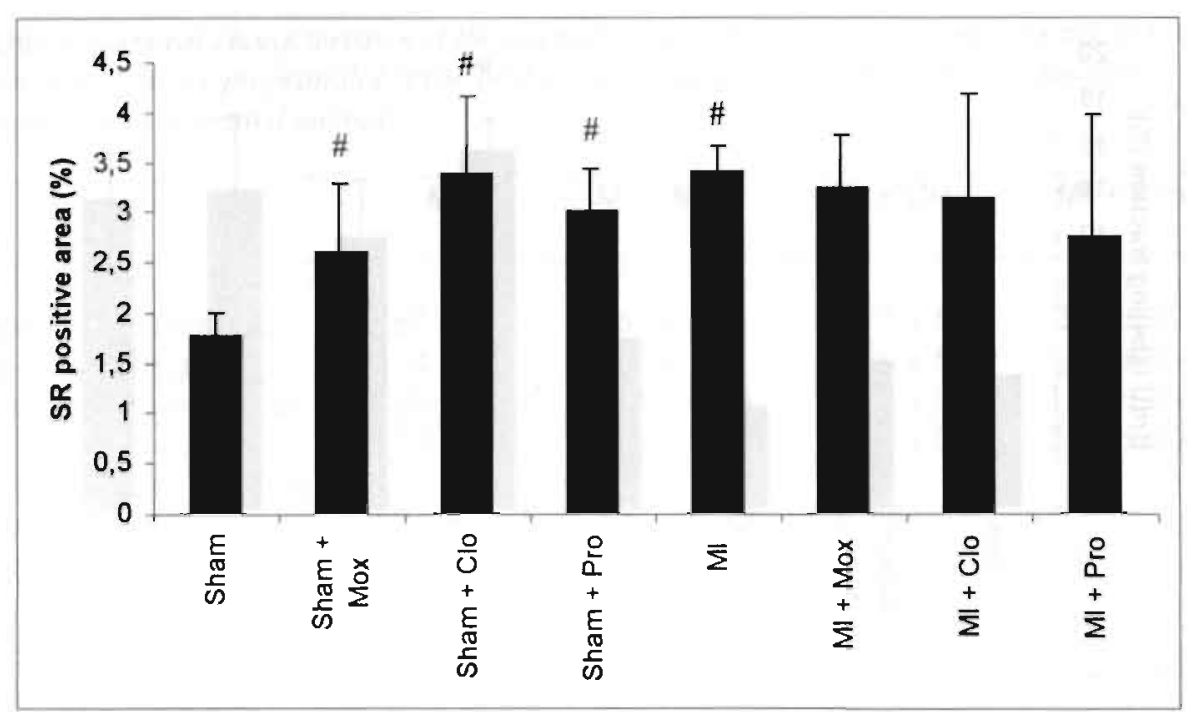

Figure 2: Effects of treatment with moxomidine (Mox), clonidime (Clo) and propranolol (Pro) on interstitial collagen fractions in the left ventricle of sham-operated and infarcted rats.

", $P<0.05$ as compared to sham-operated rats.

\section{Discussion}

There is now considerable interest in the use of sympatholytic drugs in the treatment of heart failure, based on the observed beneficial effects of $\beta$ adrenoceptor blocking drugs in clinical trials for this syndrome ${ }^{18-20.24}$. Evidence for involvement of the SNS in the control of interstitial cardiac remodeling was extensively discussed in the introduction to this thesis and in the previous chapter. Based upon the proposed suppression of arrhythmias as one of the potential mechanisms for the improvement in clinical outcome ${ }^{24.26}$, together with the notion that cardiac interstitial fibrosis contributes to the development of arrhythmias, we sought to investigate the effects of $\beta$-adrenoceptor blockade and central sympatholysis on interstitial changes following $\mathrm{MI}$ in rats. The experiments also follow the observations in the previous chapter which led us to propose that, the (presumed) sympathetic component in the control of collagen changes is maximally activated in this model for heart failure, albeit that, at least in the rat, $\alpha_{1-}$, rather than $\beta$-adrenergic mechanisms seemed to be involved. 
In the present study we did not observe any signiticant effects of the $\beta$-blocker propranolol, nor of the centrally acting sympatholytic drugs clonidine and moxonidine on cardiac interstitial remodeling following $\mathrm{MI}$, which leads us to discard our previous hypothesis. Rather, all treatments did increase interstitial collagen deposition in sham-operated animals, without affecting interstitial DNAsynthesis.

In the previous chapter, increased interstitial collagen deposition was observed in dobutamine-treated, but not in milrinone-treated sham-operated animals. Given the pharmacological profile of the two compounds, we argued that $\alpha_{1}$ adrenoceptor stimulation might be responsible for this phenomenon. Results in the present study with propranolol do not argue against this. Beta-adrenoceptor blockade results in activation of the baroreflexes, which, in turn, activates the $\mathrm{SNS}^{37}$. In fact, the observed increase in peripheral resistance following propranolol has been suggested to depend upon this SNS-activation ${ }^{38}$. Thus, in the propranolol-treated sham-operated animals, this SNS activation results in $\alpha_{1}$ adrenoceptor stimulation in face of $\beta$-blockade. In MI-animals, propranolol did not affect interstitial collagen, which suggests that control mechanisms other than $\beta$-adrenergic receptors may be of greater importance in this condition.

In view of the results in the previous chapter, one should also expect increased interstitial DNA synthesis during propranolol treatment. Although, in shamanimals, there was a tendency to an increase in DNA synthesis (LF $5.9 \pm 1.1 \%$ in controls; $7.6 \pm 1.0 \%$ in treated animals), this effect did not reach statistical significance, and was absent in MI-animals. Possibly, endogenous $\alpha_{1}$-stimulation (through baroreflexes) during propranolol treatment is less efficient than dobutamine in MI animals. Alternatively, because one of the consequences of $\beta$ blockade is a reduction of plasma renin-activity ${ }^{39}$, a stimulatory effect of $\alpha_{1}$ adrenergic stimulation might be canceled by a reduction of circulating angiotensinII.

Clonidine and moxonidine did also not affect cardiac interstitial remodeling following $\mathrm{MI}$ in the doses used in the present study. In separate hemodynamic experiments in sham and MI-rats (J. Smits et al., unpublished observations), both drugs did reduce blood pressure and heart rate at the present doses, which indicates effective inhibition of sympathetic activity. The fact that under these conditions interstitial remodeling is not affected, clearly indicates a lack of involvement of the SNS in this process following MI.

In sham-operated animals, similar to propranolol, both agents increased interstitial collagen deposition. In contrast to what was argued for propranolol, $\alpha_{1}-$ 
adrenoceptor stimulation should not occur during these treatments. Thus, alternative mechanisms should be involved. Both drugs combine $\alpha_{2^{-}}$and imidazoline-receptor stimulatory properties ${ }^{40,4}$. With respect to fibrosis, the importance of $\alpha_{2}$-adrenoceptors and imidazoline-receptors is not clear, since the presence of these receptors has not been documented on (collagen synthesizing) cardiac fibroblasts. Possibly, these receptors mediate a stimulatory effect on collagen synthesis in cardiac rat fibroblasts. If so, this pathway is again of minor importance following MI. This aspect needs, however, further studies.

With respect to collagen deposition, our results in the present study appear not in accordance with data from a study that has recently addressed the effects of $\beta$ blockade and central sympathetic inhibition in rats following $\mathrm{MI}^{36}$. These authors studied the effects of metoprolol as a $\beta$-adrenoceptor blocker and CHF-1024, with combined $\alpha_{2}$ - and dopamine type- 2 receptor agonist activity, as a centrally acting compound. In that study, both drugs did reduce collagen, upon treatment of $\mathrm{Ml}$ animals from 2-3 months after MI, although levels were not normalized. The authors did not provide data from sham-operated animals. Obviously, the main difference between the two studies is the timing and duration of the treatment. Taken together, their and our study suggest that a temporal component is involved. It is conceivable that, over time, the quantitative contributions of the different systems that may control interstitial remodeling cliange. In fact. differences in activation-state after MI have been documented for the (local cardiac) renin-angiotensin system ${ }^{42,43}$ in rats, which is only activated in the first weeks after MI, and the SNS which, after an initial rapid activation, is normalized in the first week and re-activated around 3 months after $\mathrm{MI}^{+4}$. The time-frames of activation and de-activation of these processes fit with the observations in both studies.

In conclusion, the present studies show that the SNS does not contribute to the control of cardiac interstitial remodeling in the first weeks following MI, although we can not nule out such an involvement at a later stage. Data with propranolol lend direct liurther support for the lack of a role of $\beta$-adrenoceptors in cardiac remodeling of the interstitium and, indirectly, support our hypothesis for involvement of $\alpha_{1}$-adrenoceptors in the control of collagen deposition in shamoperated animals.

Results with moxonidine and clonidine in sham-animals suggest a role for $\alpha_{2}$ and/or imidazoline-receptors in collagen deposition. Further studies are needed to clarify the possible stimulating role of $\alpha$-adrenergic and imidazoline receptors in collagen metabolism in sham animals. 


\section{References}

1. Cleland JGF, Cowburn PJ, Morgan K: Neuroendocrine activation after myocardial infarction: causes and consequences. Heart 1996:76 (Suppl.3):53-59.

2. Rouleau J, Packer M, deChamplain J, Bichet JR, Roulcau JR, Sussex B, Arnold M. McEwan P. Cuddy TE. Nadeau TE, Wun CC, Pfeffer M: Activation of ncurohumoral systems in postinfarction left ventricular dysfunction. $J . A m$ Coll Cardiol 1993;22:390-398.

3. Sigurdsson A. Held P. Swedberg K: Short and long term neurohumoral activation following acute myocardial infarction. Am Heort J 1993;126:1068-1076.

4. Cohn JN, Levin TB, Olivari MT. Garberg V, Lura D, Francis GS, Simon AS. Rector T: Plasma norepinephrine as a guide 10 prognosis in patients with chronic heart failure. $N$ Engl $J$ Med 1984;311:819-823.

5. Benedict CR, Shelton B. Johnstone DE. Francis G. Greenberg B, Konstam M, Probstfield $\pi$. Yusuf S, for the SOLVD Investigators: Prognostic significance of plasma norepinephrine in patients with asymptomatic left ventricular dysfunction. Circulation 1996:94:690-697.

6. Pfeffer JM. Fischer TA. Pfeffer MA: Angiotensin-converting enzyme inlubition and ventricular remodeling after myocardial infarction. Ann Rev lhusiul 1995:57:805-826

7. Pfeffer MA. Lamas GA. Vaughan DE. Parisi AF. Braunwald E: Effect of captopril on progressive ventricular dilatation after myocardial infarction. $V$ Engl, J Hed 1988:319:80-86.

8. Franzosi MG. Santoro E. Zuanctti G. Baigent C. Yusuf S et al, ACE Inlibitor Myocardial Infarction Collaborative Group: Indications for ACE inhibitors in the early treatment of acute myocardial infarction. Circulation 1998:97:2202-2212
9. Pfeffer MA. SAVE Investigators: Effect of captopril on mortality and morbidity in patients with left ventricular dysfunction after myocardial infarction. $N$ Engl $J$ Med 1992:327:669-677.

10. Pfeffer MA, Greaves SC, Arnold O. Glynn RJ, et al: Early versus delayed angiotensinconverting enzyme inhibition therapy in acute myocardial infarction. The Healing and Early Afterload Reducing Therapy Trial (HEART). Circulation 1997;95:2643-2651.

11. Pfeffer MA. Braunwald E: Ventricular remodeling after myocardial infarction. Expcrimental observations and clinical implications. Circulation 1990:81:1161-1172.

12. Anversa P, Loud AV, Levicky V. Guideri G: Left ventricular failure induced by myocardial infarction. I. Myocyte hypertroply. $1 \mathrm{~m} J$ Physiol 1985;248:H876-H882.

13. Sinits JFM. Passier RCJJ, Nelissen-Vrancken HJMG. Cleutjens JPM. Kuizinga MC. Daemen MJAP: Does ACE inhibition limit stnuctural changes in the hear following myocardial infarction? Eur Heart J 1995; 16(Suppl.N):4651 .

14. Van-Krimpen C. Smits JF. Cleutjens JP. Debels JJ. Schoemaker RG. Stnyker-Boudier HA. Bosman FT. Daemen MJ: DNA synthesis in the non-infarcted cardiac interstitium after left coronary anery ligation in the rat: effects of captopril. J Mol Cell Cardiol 1991:23:12451253.

15. Jalil JE, Janicki JS. Pick R, Abrahams C. Weber KT: Fibrosis-induced reduction of endomyocardium in the rat after isoproterenol treatment. Circ Res 1989;65:258-264.

16. Weber KT. Brilla CG: Structural basis for pathologic Icft ventricular hypertrophy. Clm (ardiol 1993:16(Suppl.II):I110-II14.

17. Smits JFM, Van-Krimpen ('. Schocmaker RG. Cleutjens JPM. Datmen MJAP: Angiotensin II 
receptor blockade after myocardial infarction in rats: effects on hemodynamics, myocardial DNA synthesis and interstitial collagen content. $J$ Cardiovasc. Pharmacol' 1992;20:772-778.

18. CIBIS Investigators and Committees: $A$ randomized trial of beta-blockade in heart failure: the Cardiac Insufficiency Bisoprolol Study (CIBIS). Circulation 1994;90:1765-1773.

19. Bristow MR, O'Connell JB, Gilber EM, French WJ, Leatherman G, Kantrowitz NE, Orie J, Smucker ML, Marshall G. Kelly P. Deitchman D. Anderson JL., for the Bucindolol Investigators: Dose-response of chronic betablocker treatment in heart failure from either idiopathic or ischemic cardiomyopathy. Circulation 1994;89:1632-1642

20. Packer M, Bristow MR, Cohn JN, Colucci WS, Fowler MB. Gilbert EM. Shusterman NH. For the U.S. Carvedilol Hear Failure Study Group: The effect of carvedilol on morbidity and mortality in patients with chronic heart failurc. $N$ Engl J Med 1996;334:1349-1355.

21. Dies F, Krell MJ, Whitlow P. Liang $C$, Goldenberg I, Applefeld MM, Gilbert EM: Intermittent dobutamine in ambulatory outpatients with chronic cardiac failure. Circulation 1986;74 (Suppl. II): I1-38.

22. DiBianco R, Shabctai R, Kostuk W, Moran J, Schlant RC. Wright R: A comparison of oral milrinone, digoxin, and their combination in the treatment of patients with chronic heart frilure. N'Eng/J Med 1989;320:677-683.

23 Packer M, Carver JR, Rodeheffer RJ, Ivanhoe RJ, Dibianco R, Zeldis SM, Hendrix GH, Bommer WJ, Elkayam U, Kukin ML, Mallis GI. Sollano JA, Shannon J. Tandon PK. DeMets DL: Effect of oral milrinone on mortality in severe chronic heart failure. $N$ Engl I. Med 1991:325: 1468-1475.

24. Packer M: Beta-blockade in heart failure. Basic concepts and clinical results. Am J Hypertens 1998:11:235-37S.

25. Ferrari R, Ceconi $C$. Curello $S$, Visioli $O$ : The neuroendocrine and sympathetic nerous system in congestive heart failure. Eur Heart $J$ 1998; 19(Suppl.F):F45-F51.

26. Cohn JN: Beta-blockers in heart fuilure. Eur Heart J 1998:19(Suppl.F).F52-F55.

27. Assayag P, Carre F, Chevalier B. Delcayre C, Mansicr P, Swynghedauw B: Compensated cardiac hypertrophy: arrhythmogenicity and the new cardiac phenotype. I. Fibrosis. Cardiovasc Res 1997;34:439-444.

28. Yoshikawa T, Handa S, Anzai T, Nishimura $H$, Baba A. Akaishi M, Mitamura H, Ogawa S: Early reduction of neurohumoral factors plays a key role in mediating the efficacy of betablocker therapy for congestive heart failure. $A \mathrm{~m}$ Heart J 1996;131:329-336.

29. Benjamin IJ, Jalil JE, Tan LB, Cho K, Weber KT, Clark WA: Isoproterenol-induced myocardial fibrosis in relation to myocyte necrosis. Circ Res 1989;65:657-670.

30. Farivar RS, Crawford DC, Chobanian AV, Brecher P: Effect of angiotensin II blockade on the fibroproliferative response to phenylephrine in the rat heart. Hypertension 1995:25:809-813

31. Bhambi B, Eghbali $M$ : Effect of norepinephrine on myocardial collagen gene expression and response of cardiac fibroblasts after norepinephrine treatment. Am J Pathol 1991:139:1131-1141

32. Long CS, Harlogensis WE, Simpson PC: $\beta$ Adrenergic stimulation of cardiac non-myocytes augments the growth-promoting activity of nonmyocyte conditioned medium. J $\mathrm{Aol}$ Cell Cardiol 1993;25:915-925.

33. Pick R, Jalil JE, Janicki JS, Webcr KT: The fibrillar nature and structure of isoproterenolinduced myocardial fibrosis in the rat. $A \mathrm{~m} \mathrm{~J}$ Pathol 1989:134:365-371.

34. Fishbein MC, Lei LQ, Rubin SA: Long-term propranolol administration alters myocyte and ventricular geometry in rat hearts with and without infarcion. Circulation 1988:78:369. 375 . 
35. Gay RG, Raya TE. Goldman S: Chroni propranolol treatment promotes left ventricular dilation without altering systolic function after large myocardial infarction in rats. $J$ Cardiovasc Pharmacol 1990;16:529-536

36. Latini R, Masson S, Jeremic G. Luvara G, Fiordaliso $\mathrm{F}$. Calvillo L, Bernasconi R. Torri M, Rondelli I, Razzetti R, Bongrani S: Comparative efficacy of a DA2/alplia2-agonist and a beta-blocker in reducing adrenergic drive and cardiac fibrosis in an experimental model of left ventricular dysfunction after coronary artery occlusion. J Cardiovasc Pharmacol 1998:31:601-608

37. Struyker-Boudier HA. Smits JF. Van Essen H: The role of the baroreceptor reflex in the cardiovascular effects of propranolol in the conscious spontaneously hypenensive rat. C $\mathrm{lin}$ Sci 1979:56:163-167.

38. Smits JF, Van Essen H. Struyker-Boudier HA: Cardiovascular effects of chronic infusion of propranolol in the conscious spontancously hypertensive ral. J Pharm Pharmacol $1980 ; 32: 139-140$

39. Buhler FR, Laragh JH. Baer L. Vaughan ED. Brunner HR: Propranolol inhibition of renin secretion. A specific approach to diagnosis and treatment of renin-dependent hypertensive discases. N Engl J Med 1972;287:1209-1214.
40. Armah Bl: Unique presynaptic alpha 2-receptor selectivity and specificity of the antilypertensive agent moxonidine. Arzneimittelforschung 1988;38:1435-1442.

41. Van Zwieten PA: From alpha and beta to 11:An overview of sympathetic receptors involved in blood pressure control targets for drug treatment. J Cardiovasc Pharmacol 1996;29(Suppl.3):S5-S10.

42. Passier RCJJ, Smits JFM. Verluyten MJA. Daemen MJAP: Expression and localization of renin and angiotensinogen in rat hearl after myocardial infarction. Am J Physiol 1996:271:H1040-H1048

43. Passier RCJJ, Smils JFM, Verluyten MJA. Studer R, Drexler H, Dacmen MJAP: Activation of angiotensin-converting-enzyme expression in the infarct zone following myocardial infarction. Am J Physiol 1995;269:H1268$\mathrm{H} 1276$.

44. Cciler DL. Schiffers PM, Nelissen-Vrancken HJ. Smits JF: Time-related adaptations in plasma neurohormone levels and hemodynamics after myocardial infaretion in the rat. J Card Fail 1998;4:131-138. 



\section{General discussion}

\section{Introduction}

Until only a decade ago, inability of the dysfunctional heart to pump enough blood was held primarily responsible for the syndrome of heart failure. Thus, treatment was aimed at inotropic cardiac support and optimization of pre- and afterload $^{1}$. Activation of the sympathetic nervous system was viewed as a supportive mechanism to make the heart contract more forcefully in the presence of compromised function and the use of b-blockers was contra-indicated, because of their negative inotropic actions ${ }^{2}$. However, powerful inotropic agents, which, thus, seemed logical therapy in heart failure, were found to increase mortality. Negative effects on prognosis were observed in particular with agents that increase intracellular cyclic AMP levels, either by increasing its production through b-adrenergic stimulation, or through inhibition of its breakdown $n^{3-5}$. Furthermore, the degree of neurohumoral activation was demonstrated to negatively correlate with long-term prognosis ${ }^{6-8}$. 
On this basis it is now assumed that endogenous neurohumoral activation in heart failure eventually becomes maladaptive, leading to progression of the syndromey A fundamental aspect of the neurohumoral hypothesis is that endogenously activated control mechanisms in heart failure, like the renin-angiotensin system (RAS) and the sympathetic nervous system (SNS), act on cardiac structure and thereby influence the natural course of heart failure. Ventricular remodeling after acute myocardial infarction (MI) is a precursor of the development of overt heart failure and is an important predictor of mortality ${ }^{10}$.

Experimental and clinical observations of the success of ACE-inhibitors after MI and in heart failure were the first to lend support to this hypothesis. These drugs are supposed to exert their therapeutic effects through interference with cardiac structural remodeling (i.e. cardiac hypertrophy and fibrosis). Later trials have similarly pointed to the success of b-blockers in the treatment of heart failure. The underlying effect of these drugs, remains, however, unclear.

The aim of this thesis was to study, in a rat model for MI, the involvement of interstitial cardiac fibrosis and endothelial cell proliferation in the early cardiac response to $\mathrm{MI}$, and consequences for cardiac function and perfusion. Moreover, we attempted to further characterize the involvement of the renin-angiotensin system and the sympathetic nervous system in these responses.

The most important findings may be summarized as follows:

- Following MI, the early enhanced DNA synthesis in the non-infarcted myocardium is localized to a substantial extent in endothelial cells, indicating that early post-infarction remodeling includes a vascular growth response (chapter 2).

- Inhibition of DNA synthesis is associated with attenuated cardiac function after Ml (chapter 4). Such inhibition not only occurs during early ACE inhibition", but also during $\mathrm{AT}_{2}$ receptor inhibition, but not $\mathrm{AT}_{1}$ receptor inhibition (chapter 4). Early ACE inhibition after MI inhibits fibrosis ${ }^{11}$, attenuates the nonmalization of coronary flow (chapter 4), and reduces cardiac function ${ }^{12}$.

- Comparison of $\mathrm{ACE}$-inhibition and selective $\mathrm{AT}_{1}$ and $\mathrm{AT}_{2}$ receptor inhibition indicates that the functional effects of ACE-inhibitors following $\mathrm{MI}$ do not depend upon their interference with cardiac interstitial fibrosis. 
- Beta-adrenoceptor blockade and central sympatholysis do not affect cardiac interstitial cell DNA synthesis and collagen content after MI (chapter 6).

- Dobutamine, most likely through stimulation of $\alpha_{1}$-adrenoceptors, increases cardiac post-infarction DNA synthesis, but not collagen content after MI (chapter 5).

\section{Remodeling and function - vascular growth and cardiac function early after myocardial infarction.}

In chapter 2, a substantial growth response as part of the early remodeling process in the non-infarcted myocardial tissue was observed. The results of the studies presented in this thesis and those of previous studies on cardiac remodeling after MI reveal an association between early structural changes and cardiac function. In rats, ACE-inhibition with captopril started immediately after infarct induction deteriorates cardiac function ${ }^{12}$, whereas late ACE inhibition ${ }^{12.13}$ was associated with cardiac functional improvement. Moreover, early but not late captopril treatment inhibited normalization of cardiac flow, and in parallel, inhibited the enhanced endothelial cell DNA synthesis after infarction (chapter 3). Similarly, early inhibition of microvascular growth and deterioration of cardiac function could be induced by antagonizing the $\mathrm{AT}_{2}$ receptor early after infarction (chapter 4). On the other hand, $\mathrm{AT}_{1}$ receptor blockade did not substantially influence proliferation of non-myocytes (endothelial cells and fibroblasts) early after $\mathrm{MI}^{14,15}$ (chapter 4), and did also not affect cardiac function ${ }^{14}$ (chapter 4). As summarized in table 1, the effects of ACE inhibition and angiotensin II receptor blockade on other important clianges of the post-infarct remodeling process - like cardiac hypertrophy and interstitial fibrosis - were not correlated with cardiac function. 
Table 1: Early effects of interventions in the renin-angiotensin system following $M$.

\begin{tabular}{llll}
\hline & ACE- inhibition & AT 1 -blockade & AT $_{2}$-blockade \\
\hline Cardiac hypertrophy & $\downarrow /=$ & $\downarrow /=$ & $=$ \\
Cardiac fibrosis & $\downarrow$ & $\downarrow$ & $=$ \\
DNA synthesis & $\downarrow$ & $=$ & $\downarrow$ \\
Cardiac function & $\downarrow$ & $=$ & $\downarrow$ \\
\hline
\end{tabular}

Thus, the data suggest that the increase in DNA synthesis early after MI is beneficial for cardiac function and may be viewed as a physiological adaptation of the hypertrophied heart to infarction. Morphometric studies indicate that the increase in capillaries in the non-infarcted myocardium is disproportionate witl cardiomyocyte growth $^{16}$. The substantial contribution of endothelial cells to the increase in DNA synthesis following MI thus makes it attractive to speculate that inhibition of this capillary growth response after infarction results in vascular insufficiency and relative energy starvation of the contracting myocardium ${ }^{17}$. This energy starvation may further reduce the already deteriorated cardiac performance during early $\mathrm{ACE}$ inhibition or $\mathrm{AT}_{2}$ blockade. The implied role of angiotensin II (AngII) in angiogenesis is further corroborated by earlier observations in rabbit cornea $^{18}$, dog kidney $^{19}$, rat skeletal muscle ${ }^{20}$ and chick chorioallantoic membrane $\mathrm{e}^{21.22}$.

Myocardial neovascularization is an important physiological response to myocardial ischemia ${ }^{23}$. The development of collateral vessel growth has been extensively studied in several animal models. Collateral vessels can be categorized in mainly two classes, each of them probably with different underlying regulatory mechanisms: i) capillary collaterals (angiogenesis) and ii) muscular vessels (vasculogenesis) ${ }^{24}$. In porcine ischemic models of gradual coronary artery constriction or coronary microembolization, proliferative activity of endothelial cells as determined by ${ }^{3}[\mathrm{H}]$ thymidine labeling, in situ hybridization of histone $\mathrm{H} 3$ and immunochemical PCNA/cyclin positivity, has been shown to occur in capillaries ${ }^{25.26}$. In canine models, gradual constriction of the left circumflex artery resulted in growth of large epicardial collaterals. It is not possible to fit our findings of vascular growth after infarction in either of these models. Analogous to the porcine model we observed in our rat model proliferative activity of endothelial cells at the capillary level (chapter 2) 
However, in the porcine model the capillary vessel growth has been observed in the vicinity of micronecroses. This vessel growth seems to be comparable with the vascular growth response in the infarction area in our model, as part of a wound healing process. The capillary proliferation observed in myocardial areas remote from the infarction (chapter 2) has no obvious co-localization with tissue necrosis or inflammation.

\section{Function of the $\mathrm{AT}_{2}$ receptor after myocardial infarction.}

Biological actions of AngII are mediated through $\mathrm{AT}_{1}$ and $\mathrm{AT}_{2}$ receptor subtypes. The $\mathrm{AT}_{1}$ receptor has classically been recognized to mediate the majority of effects of AngII associated with the regulation of blood pressure, fluid volume homeostasis, and stimulation of cell growth ${ }^{27}$. Little information regarding the physiological roles of $\mathrm{AT}_{2}$ is available, but in recent years it has become more evident that also the $\mathrm{AT}_{2}$ receptor is involved in growth and differentiation processes and in blood pressure regulation ${ }^{28}$, although inconsistent observations have been made (table 2).

The $\mathrm{AT}_{2}$ receptor is abundant in the developing fetus and rapidly disappears after birth $^{29.30}$. Re-expression or upregulation of the $\mathrm{AT}_{2}$ receptor occur during the healing process of skin wounds ${ }^{31}$ and in cardiovascular disease such as $\mathrm{Mi}^{32}$, hypertension ${ }^{33}$ and ischemia ${ }^{3.4}$. In humans, enhanced $\mathrm{AT}_{2}$ receptor expression has been observed in failing hearts ${ }^{35-37}$. These findings suggest a role of the $\mathrm{AT}_{2}$ receptor in development, growth and in cardiac pathophysiology.

Taken all together, involvement of the renin-angiotensin system in growth appears to be a complex process. The differential role of $\mathrm{AT}_{1}$ and $\mathrm{AT}_{2}$ receptors may depend on cell type, species and experimental conditions. Data from the present thesis and from previous experiments in our laboratory indicate, early in the course of $\mathrm{MI}$ in rats, a role for $\mathrm{AT}_{1}$ receptors in cardiac hypertrophy and fibrosis, whereas the $\mathrm{AT}_{2}$ receptor is involved in angiogenesis 
Table 2: Literature data on the effects of $A T_{1}$ and $A T_{2}$ receptor antagonism on the cardiovascular system.

\begin{tabular}{|c|c|c|c|c|}
\hline & \multicolumn{2}{|c|}{$\begin{array}{r}A T_{1} \text {-antagonism } \\
\text { references }\end{array}$} & \multicolumn{2}{|c|}{$\begin{array}{r}\mathrm{AT}_{2} \text {-antagonism } \\
\text { references }\end{array}$} \\
\hline $\begin{array}{l}\text { Cardiac hypertrophy / myocyte } \\
\text { hypertrophy }\end{array}$ & $\begin{array}{l}\downarrow \\
=/ \uparrow\end{array}$ & $\begin{array}{l}38,39 \\
40-43\end{array}$ & $\uparrow$ & $\begin{array}{l}43,44 \\
39\end{array}$ \\
\hline Myocyte apoptosis & $\downarrow$ & 45 & $=$ & 45 \\
\hline $\begin{array}{l}\text { Non-myocyte (endothelial cells } \\
\text { and fibroblasts) proliferation }\end{array}$ & & 14,15 & & \\
\hline Fibroblast proliferation & $\downarrow$ & 46 & $\uparrow$ & 47 \\
\hline $\begin{array}{l}\text { Endothelial cell proliferation/ } \\
\text { capillary growth }\end{array}$ & $\downarrow$ & $\begin{array}{l}48 \\
49-51\end{array}$ & $\uparrow$ & 48 \\
\hline VSMC hypertrophy & & $\begin{array}{l}52 \\
53\end{array}$ & $\downarrow$ & $53-55$ \\
\hline VSMC proliferation & $\downarrow$ & 56,57 & $\begin{array}{l}\uparrow I= \\
\downarrow\end{array}$ & $\begin{array}{l}57,58 \\
53\end{array}$ \\
\hline Vasoconstiction & $\downarrow$ & 59 & $\uparrow$ & 59 \\
\hline
\end{tabular}

\section{Interference with the sympathetic nervous system following MI.}

As pointed out above, sympathetic activation in heart failure is nowadays regarded as deleterious. Proposed mechanisms for how the sympathetic nervous system (SNS) exerts its adverse effects have recently been reviewed by Packer ${ }^{60}$ and include:

- Induction of myocardial ischemia. Norepinephrine can induce cardiac hypertrophy but can restrict the ability of the coronary arteries to supply blood to the thickened ventricular wall ${ }^{61}$. Activation of the SNS can cause tachycardia with adverse effects on the relationship between myocardial energy supply and demand. 
- Tachycardia-induced exacerbation of the abnormal force-frequency relation of the failing heart.

- Induction of dysfunction and death of cardiomyocytes. By increasing cyclic AMP, norepineplurine can increase the concentration of intracellular calcium, which may lead to a state of calcium overload and cell necrosis.

- Stimulation of growth and induction of oxidative stress and apoptosis in cardiac cells.

- Provocation of arrhythmias through biochemical and structural alterations (hypertrophy and fibrosis).

Thus, a direct effect on myocyte and interstitial cell growth may be a key factor in the actions of agents interfering with the $\mathrm{SNS}^{2}$.

The primary mode of death during treatment with positive inotropic agents in heart failure is "sudden", i.e. from cardiac dys-rhythmias. The cause of the observed arrythmogenic effects of sympathomimetic stimulation by inotropic agents is multifactorial (see above). One of the proposed contributing factors is fibrosis (see above). Results described in chapter 5 do, however, not support an effect on post-infarct fibrosis of the non-infarcted heart after dobutamine or milrinone early after MI. This indicates that a possible arrhythmogenic effect associated with these drugs is not due to excessive fibrosis in this context. However, effects on cardiac fibrosis by long-term treatment of these drigs in the context of chronic heart failure cannot be excluded.

It has also been shown in the present thesis, that adrenergic stimulation by dobutamine enhanced post-infarction DNA synthesis of endothelial cells and fibroblasts. Early interstitial cell proliferation after infarction appears to be important for the condition of the heart; inhibition of this DNA synthesis is associated with a deterioration of the already impaired cardiac function (chapter4). The biological significance of the extra stimulated DNA synthesis is not quite clear. Extra stimulation of DNA synthesis has potential beneficial consequences (cf. above): stimulation of vascular growth can be viewed as a beneficial effect in the failing heart.

Effects of inhibitors of adrenergic activity on cardiac remodeling following $\mathrm{MI}$ have not been studied extensively. It is conceivable, that part of the beneficial effects of these agents is due to their protective effect on catecholamine-induced cardiac myocyte necrosis and associated cardiac microscarring ${ }^{62}$. 
However, the results in the present thesis show that $\beta$-adrenergic blockade and centrally acting sympatholytic agents do not affect interstitial remodeling early after infarction (chapter 6). This indicates that the endogenous SNS does not initiate post-infarction collagen deposition. On the other hand, later in the course of post-infarction heart failure (therapy initiated after 2 months), a reduction of cardiac fibrosis has been observed after long-term treatment with similar agents ${ }^{63}$.

Cardiac fibrosis appears in two morphologically distinct forms. This includes a reactive form, expressed as perivascular/interstitial fibrosis which appears in the absence of myocyte necrosis, and a reparative fibrosis or microscopic scars that replace necrotic myocytes ${ }^{64.65}$. The failing heart is initially characterized by reactive fibrosis, and the contribution of reparative fibrosis together with increasing myocyte necrosis becomes increasingly more important during progression of heart failure ${ }^{65}$. In our early infarct model, the pattern of fibrosis is reactive without visible cell necrosis in the non-infarcted myocardium ${ }^{(6)}$. The RAS, rather than the SNS, seems to be involved in collagen deposition at this stage after infarction. The forn of collagen has not been described in the study of Latini et al. ${ }^{63}$, but it is possible that, in this later stage of post-infarction heart failure, the contribution of the SNS in the regulation of collagen deposition is based on toxic effects of excessive adrenergic activity causing myocyte necrosis resulting in reparative fibrosis. This might explain the dissociation of effects on collagen of early versus late inhibition of the SNS after infarction. Thus, the SNS might play a more substantial role in maintaining and increasing collagen levels in a later stage of heart failure, rather than initiating increased collagen formation early after infarction.

From the studies presented in this thesis, it can be concluded that endogenous SNS stimulation in the early phase after infarction does not contribute to the transiently increased DNA synthesis and initiation of cardiac fibrosis. Also, clinically relevant drugs like the $\beta$-blocker propranolol and the centrally acting sympatholytic agents clonidine and moxonidine behave indifferently with respect to the interstitial remodeling response in the first weeks after infarction, at least in the rat model. It follows that it is unlikely that the observed beneficial effects of $\beta$-blockade in the setting of acute myocardial infarction relate to effects on the interstitium. 


\section{Implications and perspectives}

From previous studies and results from the present thesis it can be hypothesized that the early responses of the viable myocardium after infarction bear inherent adaptive and maladaptive elements. The impact of the many structural and molecular changes of the remodeling process after infarction is not known, but it seems conceivable that capillary growth is of great clinical benefit. Understanding how we might be able to separate beneficial and detrimental responses of pharmacological interventions is an important research issue. The finding that the $\mathrm{AT}_{2}$ receptor might mediate a novel cardioprotective effect, i.e. stimulation of vascular growth early after infarction, may have important implications for the treatment of acute myocardial infarction and heart failure. The relevance of the biological effects of $\mathrm{AT}_{2}$ receptors is underlined by the application of new forms of therapy for heart failure that may be available in the near future. Specific AT receptor blockers have already been approved for the treatment of hypertension. The clinical question whether these drugs are equally effective as, or even superior over the established treatment with ACE inhibitors is a subject of current investigation. During treatment with $\mathrm{AT}_{1}$ receptor antagonists in heart failure circulating AngII levels are increased, resulting in enhanced activation of the unopposed $\mathrm{AT}_{2}$ receptor ${ }^{67}$. Consequently, the biological actions mediated through the $\mathrm{AT}_{2}$-receptor are expected to be further enhanced under these circumstances. Interestingly, the results of the recently published ELITE trial ${ }^{68}$ suggest superiority of specific $\mathrm{AT}_{1}$ receptor blockade over $\mathrm{ACE}$ inhibition in heart failure, at least in the elderly. The mechanisms underlying these more beneficial therapeutical effects by losartan treatment are not known, but might be the result of selective $\mathrm{AT}_{2}$ receptor stimulation.

Data obtained in experimental models in which the capacity of the vascular bed is enlanced also point to a role of the myocardial vascularity in cardiac function For example, in a porcine model of cardiac ischemia, the use of an adenovirus expressing human Fibroblast Growth Factor-5 (FGF-5) induced increased blood flow to the ischemic region and improvement of contractile performance ${ }^{69}$, and an adenoviral vector expressing the Vascular Endothelial Growth Factor-121 (VEGF-121) cDNA resulted in collateral vessel development in the ischemic myocardium with concomitant significant improvement in both myocardial perfusion and function ${ }^{70}$.

Indeed, recently much attention has been paid to improvement of the vascularization of the heart as a therapeutic goal. This novel strategy for the 
ttedtment of vascular insufficiency has been termed "therapeutic angiogenesis' (reviewed by Rivard et Isner ${ }^{\text {l1 }}$ ). Results from animal models support the potential feasibility of recombinant growth factor therapy in myocardial angiogenesis ${ }^{71}$, and a recent clinical report documented that increased myocardial angiogenesis had been achieved in humans with severe coronary artery disease by direct intramyocardial injection of recombinant Fibroblast Growtl Factor-1 (FGF-1) protein $^{71.72}$. Phase I clinical trials are now under way to evaluate the results of direct myocardial revascularization (DMR), also known as 'laser revascularization', a technique of which one mechanism of action is supposed to be stimulation of angiogenesis ${ }^{73}$. 


\section{References}

1. McCarthy M: Is there more to heart failure than a bad pump? Lancet 1996;347:110.

2. Cohn $\mathrm{N}$ : Beta-blockers in heart failure. $3: y^{\circ}$ Ile'urt .I 1998:19(Suppl.F):F52-F5.

3. Dies F, Krell MJ, Whitlow P. Liang C. Goldenberg I. Applefeld MM. Gilbert EM Intermittent dobutamine in ambulatory outpatients with chronic cardiac failure. (irculation 1986:74 (Suppl, II): II-38.

4. DiBianco R, Shabetai R, Kostuk W, Moran J, Schlant RC, Wright R: A comparison of oral milrinone, digoxin, and their combination in the treatment of patients with chronic heart failure. $N$ Engl J Med 1989;320:677-683.

5. Packer M. Carver JR, Rodeheffer RJ. Ivanhoc RJ. Dibianco R. Zeldis SM. Hendrix GH. Bommer WJ. Elkayam U, Kukin ML. Mallis GI. Sollano JA. Shannon J, Tandon PK. DeMets DL: Effect of oral milrinone on mortality in severe chronic hear failure. $\mathrm{N} / \mathrm{kngl}$ J Med 1991:325:1468-1475.

6. Cohn N, Levin TB, Olivari MT, Garberg V, Lura D. Francis GS. Simon AS, Rector T: Plasma norepinephrine as a guide to prognosis in patients with chronic heart failure. $V$ Eng/ $J$ Med 1984;311:819-823.

7. Francis GS, Cohn JN. Johnson G. Reclor TS. Goldman S. Simon A: Plasma norepincphrine plasma renin activity: and congestive heart failure. Relations to survival and the effects of therapy in V-HeFT II. The V-HeFT VA Cooperative Studics Group. Cir: ulation 1993;87:VI4)-VI48.

8. Benedict CR. Shelton B. Johnstone DE. Francis G. Greenberg B. Konstam M. Probstiveld J. Yusuf S. for the SOLVD Investigators: Prognostic significance of plasma norepinephrine in patients with asy inptomalic lef ventricular dysfunction. Circulation 1996:94:690-697.
9. Packer M: The neuroliormonal hypothesis: a theory to explain the mechanism of disease progression in heart failure. $J \mathrm{Am}$ Coll Cardiol $1992 ; 20: 248-254$.

10. Pfeffer MA, Braunwald E: Ventricular remodeling after myocardial infarction. Experimental obsenations and clinical implications. Circulation 1990;81:1161-1172.

11. Van-Ḱrimpen C, Smits JF, Cleutjens JP, Debets JJ, Schoemaker RG. SInuker-Boudier HLA, Bosman FT. Daemen MJ: DNA synthesis in the non-infarcted cardiac interstitium after left coronary artery ligation in the rat: effects of captopril. J Mol Cell Cardol 1991;23:12451253.

12. Schoemaker RG. Debets JJ, Struyker-Boudier HA, Smits JF: Delayed bu not immediate captopril therapy improves cardiac function in conscious rats following myocardial infarction. JiMol Cell Caraliol 1991;23:187-197.

13. Pfeffer JM, Pfeffer MA, Braunwald E: Influence of chronic captopril therapy on the infarcted left ventricle of the rat. Circ Res 1985:57:84-95.

14. Smils JFM, Van Krimpen C. Schoemaker RG, Cleutjens JPM, Dacmen MJAP. Angiotensin II receptor blockade after myocardial infarction in rals: effects on hemodynamics, myocardial DNA synthesis and interstitial collagen content. J Cardiovasc Pharmacol 1992;20:772-778.

15. Taylor K. Patten RD, Smith JJ, A ronovitz MJ. Wight J. Salomon RN, Konstam MA: Divergent effects of angiotensin-convering enzyme inhibition and angiotensin II-receptor antagonisn on myocardial cellular proliferation and collagen deposition after myocardial infarction in rats. $J$ Cardiovasc Pharmacol 1998;31:654-660.

16. Anversa P, Beghi C, Kikkawa Y, Olivetti G: Myocardial infarction in rats. Infarct size, myocyte hypertrophy and capillary growth. Circ: 
Res 1986;58:26-37.

17. Katz AM: Cardiomyopathy of overload. A major determinant of prognosis in congestive heart failure. N Engl J Med 1990;322:100-110.

18. Fernandez L, Twickler J, Mead A: Neovascularization produced by angiotensin II. $J$ Lab Clin Med 1985:105:141-145.

19. Fernandez LA, Caride VJ, Twickler J, Galardy RE: Renin-angiotensin and development of collateral circulation after renal ischemia. $A \mathrm{~m} J$ Physiol 1982:243:H869-H875.

20. Nelissen-Vrancken HJMG, Stnyker-Boudier HAJ, Dacmen MJAP, Smits JFM:

Antihypertensive therapy and adaptive mechanisms in peripheral ischemia. Hypertension 1993:22:780-788.

21. Le-Noble FAC. Hckking JWM. Van-Straaten HWM. Slaaf DW. Struyker-Boudier HAJ: Angiotensin II stimulates angiogenesis in the chorio-allantoic membrane of the chick embryo. Eur J Pharmacol 1991:195:305-306.

22. Le Nobie FAC. Schreurs NHJS. Van Straaten HWM. Slaaf DW. Smits JFM. Rogg H. Struijker-Boudier HAJ: Evidence for a novel angiotensin II receptor involved in angiogenesis in chick embryo chorioallantoic membranc. $A m$ $J$ Physiol 1993:264:R+60-R+65.

23. Schaper W: Angiogenesis in the adult heart, in Drexler H, Zeilier AM, Bassenge E, Just $\mathrm{H}$ (eds): Endolhelial mechanisms of vasomotor control. Supplement to Basic Research in Cardiologv. New York, Springer-Verlag. 1991. vol 86.(Suppl 2), pp. 51-56.

24. Schaper W: Collateral vessel growth in the human heart. Rolc of Fibroblasis Growth Factor-2. Circulation 1996:94:600-601.

25. Zimmermann R, Arras M, Ulmann C. Strasser R. Sack S, Mollnau H. Schaper J. Schaper W: Time course of mitosis and collateral growth following coronary microcmbolization in the porcine heart. Cell Tissue Res 1997:287:583590.

26. Schaper W: New paradigms for collateral vessel growth. Basic Res Cardiol 1993;88:193-198.

27. Moeller I, Allen AM, Chai S-Y, Zhuo J, Mendelsohn FAO: Bioactive angiotensin peptides. J Hum Hypertens 1998:12:289-293.

28. Csikos $\mathrm{T}$, Chung $\mathrm{O}$, Unger T: Receptors and their classification: focus on angiotensin $\mathrm{Il}$ and the AT2 receptor. $J$ Hum Hypertens 1998:12:3I1-318.

29. Tsutsumi K. Stromberg C, Viswanathan $M$, Siavedra JM: Angiotensin-II receptor subtypes in fetal tissue of the rat:Autoradiography. guanine nucleotide sensitivity, and association with phosphoinositide hydrolysis.

Endocrinologv 1991:129:1075-1082.

30. Grady EF, Sechi LA, Griffin CA, Schambelan M. Kalinyak JE: Expression of AT2 receptors in the developing rat fetus. $J$ Clin Invest 1991:88:921-933.

31. Viswanathan $M$, Saavedra JM: Expression of angiotensin II AT2 receptors in the rat skin during experimental wound healing. Peptides 1992:13:783-786.

32. Nio $Y$. Matsubara H. Murasawa S. Kanasaki M. Inada M: Regulation of gene transcription of angiotensin II receptor subtypes in myocardial infarction. J Clin Invest 1995;95:+6-54.

33. Lopez JJ, Lorell BH, Ingelfinger JR, Weinberg EO. Schunkert H, Diamant D. Tang S-S: Disiribution and function of cardiac angiotensin AT1- and AT2-receptor subtypes in hypertrophied rat hearts . Am. $J$ Phusiol 1994:267:H844-H852.

34. Wiemer G. Scholkens BA. Wagner A, Heilsch H. Linz. W: The possible role of angiotensin II subtype AT2 receptors in endothelial cells and isolated ischemic rat hearts. Journal of Hypertension 1993:11(Suppl.5):S234-235. 
35. Asano K, Dutcher DL, Port JD, Minobe WA, Tremmel KD, Roden RL, Bohlmeyer TJ. Bush EW, Jenkin MJ, Abraham WT, Raynolds MV, Zisman LS, Pcrryman MB, Bristow MR: Selective downregulation of the angiotensin II ATl-receptor subtype in failing human ventricular myocardium. Circulation 1997;95:1193-1200.

36. Haywood GA, Gullestad L, Katsuya T. Hutchinson HG. Pratt RE, Horiuchi M. Fowler MB: AT1 and AT2 angiotensin receplor gene expression in human heart failure. Circulation 1997;95:1201-1206.

37. Wharton J, Morgan K. Rutherford RAD. Catravas JD, Chester A. Whitehead BF, De Leval MR. Yacoub MH. Polak JM: Differential distribution of angiotensin AT2 receptors in the normal and failing human heart.J Pharmacol Exp Ther 1998:284:323-336.

38. Sadoshima J, Izumo S: Molecular characterization of angiolensin II-induced hypertroply of cardiac myocytes and hyperplasia of cardiac fibroblasts. Critical role of the ATl reccptor subtype. Circ Res 1993:73:413-423.

39. Price RL. Caner W. Simpson DG. Fu L. Zhao J. Borg TK. Terracio L: The effects of angiotensin II and specific angiotensin receptor blockers on cubryonic cardic development and looping patterns. Dev Biol 1997:192:572-584.

40. Raya TE. Fonken SJ. Lee RW. Daugherty S. Goldman S, Wong PC. Timmcrinans PBMWM. Morkin E: Hcmodynamic effects of direct angiotensin II blockade compared to converting enzyme inhibition in rat model of heart failure. Am J Hypertens 1991:4:334S-340S.

41. Cheung B: Increased left-ventricular mass after losartan treatment. Lancet 1997:349:17431744.

42. Capasso JM, Li P. Meggs LG, Herman MV. Anversa P: Efficacy of angiotensin-converting enzyme inhibition and ATl receptor blockade on cardiac pump performance after myocardial infarction in rats. $J$ Cardiovasc Pharmacol 1994;23:584-593.

43. Ceiler DL, Nelissen-Vrancken HJM, De Mcy JGR, Smits JFM: Effect of chronic blockade of angiotensin II-receptor subtypes on aortic compliance in rats with myocardial infarction. $J$ Cardiovasc Pharmacol 1998;31:630-637.

44. Booz GW. Baker KM: Role of type 1 and type 2 angiotensin receptors in angiotensin II-induced cardiomyocyte hypertrophy. Hypertension 1996;28:635-640.

45. Cigola E. Kajstura J, Li B, Meggs LG. Anversa P. Angiotensin 11 activates programmed myocyte death in vitro. Exp Cell Res 1997:231:363-371.

46. Schorb W. Booz GW, Dostal DE, Conrad KM, Chang KC. Baker KM: Angiotensin II is mitogenic in neonatal rat cardiac fibroblasts. Circ Res 1993; 72:1245-1254.

47. Ohkubo N, Matsubara H, Nozowa Y, Mori Y. Murasawa S. Kijima K, Maruyama K, Masaki H. Tsutumi $Y$, Shibazaki $Y$, Iwasaka T, Inada $M:$ Angiotensin type 2 receptors are reexpressed by cardiac fibroblasts from failing myopathic hamster hearts and inhibit cell growh and fibrillar collagen metabolism. Circulation 1997:96:395.4-3962

48. Stoll M. Sieckelings M. Paul M, Bottari SP, Metzger R, Unger T: The angiotensin AT2receptor mediates inhibition of cell proliferation in coronary endothclial cclls. $J$ Clin Invest 1995:95:651-657.

49. Schieffer B. Wirger A. Meybrunn M. Scitz S. Holız J. Riede UN, Drexler H: Comparative effects of chronic angiotensin-converting enzyme inhibition and angiotensin II type 1 receptor blockade on cardiac remodeling after myocardial infarction in the rat. Circulation 1994:89:2273-2282.

50. Sladck T, Sladkova J, Kolar F, Papousck F。 Cicutti N. Korecky B. Rakusan K: The effect of 
AT1 receptor antagonist on chronic cardiac response to coronary artery ligation in rats. Cardiovasc Res 1996;31:568-576.

51. Liu $Y-H$, Yang X-P, Sharov VG. Nass O, Sabbah HN, Peterson E, Carretero OA: Effects of angiotensin-converting enzyme inhibitors and angiotensin II type 1 receptor antagonists in rats with heart failure. $J$ Clin Invest 1997;99:1926-1935.

52. Chiu AT. Roscoe WA. McCall D. Timmermans PBMWM: Angiotensin II-1 receptors mediate both vasoconstrictor and hypertrophic responses in mat artic sinooth muscle cells. Receptor 1991;1:133-140.

53. Levy BI, Benessiano J, Henrion D, Caputo L. Heymes C. Duriez M. Poitevin P. Samuel JL: Chronic blockade of AT2-subtype receptors prevents the effect of angiotensin II on rat vascular structure. J Clin Invest 1996;98:418425 .

54. Levy BI: The potential role of angiotensin II in the vasculature. J Hum Hypertens 1998:12:283287.

55. Saward L. Zahradka P: The angiotensin type 2 receptor mediates RNA synthesis in Al0 vascular smooth muscle cells. $J \mathrm{Mol} \mathrm{Cell}$ Cordiol 1996:28:499-506

56. Prescott MG, Webb RL, Reidy MA: Angiotensin-converting enzyme inhibitor versus angiotensin II. ATI receptor antagonist. Effects on smooth muscle cell migration and proliferation after balloon catheter injury. $A \mathrm{~m} \mathrm{~J}$ Pathol 1991;139: 1291-1296.

57. Van Kleef EM, Fingerle J, Daemen MJ: Angiotensin II-induced progression of neointimal thickening in the balloon-injured rat carotid artery is ATl receptor mediated. Arterioscler Tromb Fasc Biol 1996:16:857-863.

58. Nakajima $M$, Hutchinson HG. Fujinaga $M$, Hayashida W, Morishita R, Zhang L, Horiuchi M. Pratt RE, Dzau VJ: The angiotensin II type
2 (A'2) receptor antagonizes the growth efocts of the ATI receptor: gain-of-function study using gene transfer. Proc Vall load sci L S.1 1995:92:10663-10667.

59. Munzenmaier DH. Greene AS: Opposing actions of angiotensin Il on microvascular growth and arterial blood pressure. Hypertension 1996:27:759-765.

60. Packer M: Bcta-blockadc in heart failurc. Basic concepts and clinical results. Am J Hyperten.s 1998;11:23S-37S.

61. Anversa P. Ricci R. Olivetti G: Quantitative structural analysis of the myocardium during physiologic growth and induced cardiac hypertrophy: a roview. J Am Coll Cardiol 1986:7:1140-1149.

62. Pick R Jalil JE. Janicki JS, Weber KT: The fibrillar nature and structure of isoproterenolinduced myocardial fibrosis in the rat. $A m J$ Pathol 1989; 134:365-371.

63. Latini R. Masson S, Jeremic G, Luvara G, Fiordaliso F, Calvillo L, Bernasconi R, Torri M, Rondelli I, Razzetti R, Bongrani S:

Comparative efficacy of a DA2/alpha2-agonist and a beta-blocker in reducing adrenergic drive and cardiac fibrosis in an experimental model of left ventricular dysfunction after coronary artery occlusion. J Cardiovasc Pharmacol 1998:31:601-608.

64. Weber KT, Brilla CG: Pathological hypertrophy and cardiac interstitiun. Fibrosis and reninangiotensin-aldosterone system. Circulation 1991:83:1849-1865.

65. Weber KT: Extracellular matrix remodeling in hear failure. Circulation 1997;96:4065-4082.

66. Cleutjens JPM. Verluyten MJA. Smits JFM, Dacmen MJAP: Collagen remodeling after myocardial infarction in the rat hean. $A \mathrm{~m} \mathrm{~J}$ Pathol 1995; 147:325-338. 
67. Christen Y, Waeber B. Nussberger J. Porilic M, Borland RM, Lec RJ. Maggon K. Sluum L. Timmermans PB, Bnunner HR: Oral administration of DuP 753, a specific angiotensin II receptor antagonist. in normal male volunteers. Inhibition of pressor response to cxogenous angiotensin I and II. circulatien 1991:83:1333-1342.

68. Pitt B. Segal R, Martinez FA, Meurers G, Cowley AJ. Thomas I, Deedwania PC. Sanvely DB. Chang PI: Randomised trial of losartan versus captopril in patients over 65 with heart failure (Evaluation of Losartan in the Elderly Study, ELITE). Lancet 1997:349:747-752.

69. Giordano FJ, Ping P, McKirnan D, Nozaki S, DeMaria AN, Dillmann WH, Mathieu-Costello O. Hammond HK: Intracoronary gene transfer of fibroblast growth factor- 5 increases blood flow and contractile function in an ischemic region of the heart. Nature Medicine 1996:2:534-539.

70. Mack CA. Patel SR, Schwarz EA, Zamzonico P. Hahn RT. Ilercil A. Devereux RB. Goldsmith
SI, et al: Biologic bypass with the use of adenovirus-medialed gene transfer of the complementary deoxyribonucleic acid for vascular endothelial growth facior 121 improves myocardial perfusion and function in the ischemic porcine heart. J Thorac Cardiovasc Surg 1998;115:168-176.

71. Rivard A, Isner JM: Angiogenesis and vasculogenesis in treatment of cardiovascular disease. Mol Med 1998:4:429-440.

72. Schumacher B. Pecher P, Von Specht BU, Stegmann $T$ : Induction of neoangiogenesis in ischemic myocardium by human growth factors: first clinical results of a new treatment of coronary heart disease. Circulation 1998;97:645-650.

73. Kornowski R, Hong MK, Leon MB: Current perspectives on direct myocardial revascularization. Am J Cardiol 1998;81:44E$48 \mathrm{E}$. 


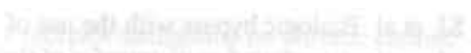

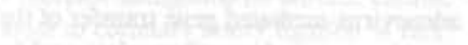

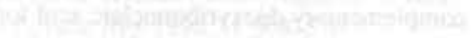

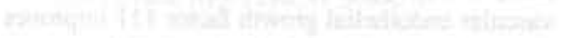

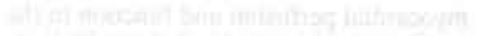

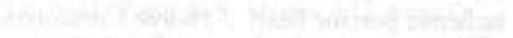

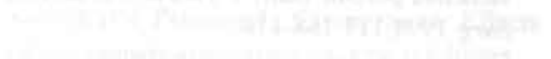

(1)

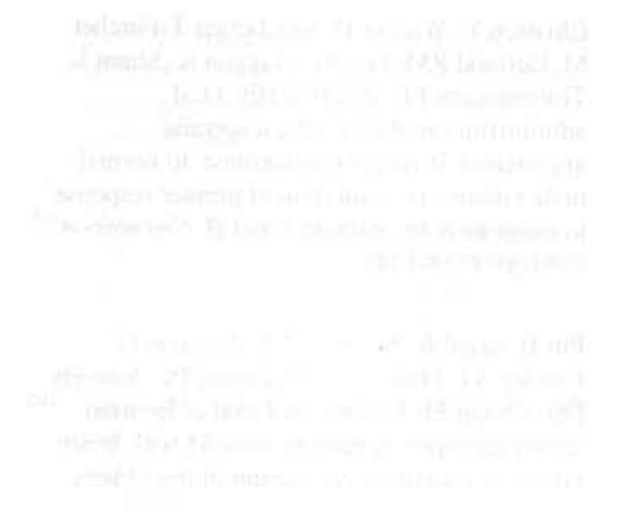




\section{Summary \\ Samenvatting \\ Curriculum vitae \\ Dankwoord}

\section{Summary}

Heart failure is a very common syndrome with an increasing incidence and prevalence. One of the major causes of heart failure is acute myocardial infarction. Understanding of the pathophysiology of heart failure is important for an adequate approach to therapy. At the present time, it is postulated that in heart failure, endogenously activated neurohumoral systems, like the renin-angiotensin system and the sympathetic nervous system lead to progression of the syndrome. A fundamental aspect of this hypothesis is that these control mechanisms can induce structural changes in de heart (termed 'cardiac remodeling') and thereby influence the natural course of heart failure.

The rat infarct model is a well established experimental model of cardiac failure. In this model, cardiac remodeling has been examined extensively. It has been shown that in the non-infarcted part of the mycardium, besides changes in 
myocytes, alterations take place in the cardiac interstitium, like an increase in DNA synthesis and in collagen content.

The aim of the experiments presented in the present thesis is to further investigate, in a rat model of myocardial infarction, the regulation of these changes which occur in the interstitium of the non-infarcted part of the myocardium, by further characterizing the effects of the renin-angiotensin system and the sympathetic nervous system on these responses.

Chapter 1, a general introduction, provides an overview of the literature concerning several aspects of the cardiac remodeling process following myocardial infarction. This is followed by a discussion on the renin-angiotensin system and the sympathetic nervous system. Attention is paid to the relationship between these two systems and cardiac structure in particular. Finally, the aim and the hypothesis of the present thesis is presented.

In chapter 2 the phenotype of the cells participating in the increased postinfarction I)NA synthesis was further identified. Previous studies have shown that the increase in DNA synthesis was almost entirely found in interstitial cells, i.e. fibroblasts and endothelial cells. In this chapter a method was described by which DNA synthesizing endothelial cells can be visualized in paraffin embedded rat heart tissue.

First, in order to find a reliable endothelial cell marker to visualize the capillary network in paraffin embedded rat heart tissue, a panel of several "vascular cell markers" was evaluated. Best staining results were obtained with the lectin Griffonia simplicifolia I (GSI).

Second, the percentage of DNA synthesizing endothelial cells was quantified in sham-operated and infarct animals. To this end, myocardial infarction (MI) was induced by ligation of the left anterior descending coronary artery in Wistar rats. Sham-operated (same surgery procedure without ligation) animals served as controls. MI rats and sham-operated rats were infused with 5-bromo-2'deoxyuridine (BrdU) to label DNA synthesizing cells. A double staining technique using the lectin GSI together with an anti-BrdU-antibody was developed to visualize DNA synthesizing endothelial cells. In this way, the majority of DNA synthesizing cells was identified in 'non-endothelial cells', the fibroblasts. However, a substantial proportion (about one-third) of DNA synthesis was shown to occur in microvascular endothelial cells, likely reflecting enhanced 
growth of the microvasculature in the non-infarcted part of the left ventricle in the first two weeks after infarction.

In chapter 3 the effects of early treatment with two ACE-inhibitors (captopril or perindoprilat) on post-infarction DNA synthesis of endothelial and nonendothelial cells were investigated. Results indicated that both early captopril and perindoprilat treatment inhibited total DNA synthesis in MI hearts. By means of the double staining technique (using a monoclonal anti-BrdU-antibody and the lectin GSI, as described in chapter 2) it was shown that only in captopril treated hearts, this inhibition was associated with a disproportionate inhibition of the endothelial cell proliferation.

Also, the functional consequences of ACE-inhibition on endothelial cell proliferation, reflected by the effect on maximal coronary flow, were determined in separate groups. In isolated retrogradely perfused rat hearts, it was shown that maximal coronary flow was completely nonnalized in MI hearts within three weeks after surgery. Early captopril (from day 0-21 after surgery), but not late captopril (day 21-35), inhibited the normalization of maximal coronary flow in MI hearts.

Thus, the results indicated that early captopril treatment inhibited endothelial cell proliferation and coronary vessel growth following myocardial infarction.

Having determined the effects of ACE-inhibition on total DNA synthesis and the DNA synthesis in endothelial cells, chapter 4 describes the effects of blockade of the angiotensin II receptor subtypes $1\left(\mathrm{AT}_{1}\right)$ and $2\left(\mathrm{AT}_{2}\right)$ on these parameters. The $\mathrm{AT}_{2}$ receptor antagonist $\mathrm{PD} 123319$, but not the $\mathrm{AT}_{1}$ receptor antagonist GR138950C significantly reduced total interstitial DNA synthesis. Both agents did not alter the fraction of DNA synthesizing endothelial cells

The effects of blockade of both these AT receptor subtypes on hemodynamic parameters were also studied in parallel experiments. Myocardial infarction reduced cardiac function at 3 weeks after myocardial infarction. PD123319 further reduced the already impaired cardiac function, whereas GR $138950 \mathrm{C}$ did not show such effect.

Thus, the data indicate that the increase in DNA synthesis in cardiac endothelial cells and non-endothelial cells after myocardial infarction is - at least partiallymediated through $\mathrm{AT}_{2}$ receptors. In addition, the inhibitory effects of $\mathrm{AT}_{2}$ receptor blockade on interstitial cell DNA synthesis and cardiac function suggest that the hemodynamic effects of $\mathrm{AT}_{2}$ receptor blockade after myocardial infarction may 
depend upon reduction of DNA synthesis of endothelial cells and/or nonendothelial cells in the hypertrophying myocardium.

Evidence exists that, besides the renin angiotensin system, the sympathetic nervous system may also influence the process of remodeling in the cardiac interstitium. However, effects of drugs interfering with the sympathetic nervous system on interstitial remodeling early after infarction are not known. Therefore, effects of early treatment with different pharmacological agents either stimulating (chapter 5) or reducing (chapter 6) the adrenergic drive on cardiac DNA synthesis and collagen content were studied in the infarct-model.

In chapter 5 the effects of adrenergic stimulation by dobutamine ( $\alpha 1-$ and $\beta$ adrenergic) were characterized in rats following myocardial infarction. In a parallel study the effects of milrinone (a phosphodiesterase III inhibitor) were determined. Phosphodiesterase III inhibition results in inhibition of the degradation of the second messenger cyclic adenosine monophosphate (cAMP), thereby mimicking $\beta$-adrenoceptor stimulation in a non- $\beta$-adrenoceptor mediated fashion. The relative collagen area of the non-infarcted left ventricle was determined morphometrically. The collagen content was significantly increased in the left ventricle of infarct animals, which confinns previous observations. The results indicate that adrenergic stimulation by dobutamine -possibly through stimulation of $\alpha_{1}$-adrenoceptors- after myocardial infarction affects the structure of the cardiac interstitium through further stimulation of DNA synthesis, but does not affect cardiac collagen content. The dobutamine-induced collagen deposition in sham animals in the present study may also depend upon $\alpha_{1}$-adrenergic stimulation, since phosphodiesterase inhibition by milrinone did not affect this parameter. In MI animals, collagen deposition may already be stimulated to its maximum.

There is now considerable interest in the use of sympatholytic drugs in the treatment of heart failure. Beneficial effects of $\beta$-adrenoceptor blocking drugs in clinical trials for this syndrome have been observed. Based upon the proposed suppression of arrhythmias as one of the potential mechanisms for the improvement in clinical outcome, together with the notion that cardiac interstitial fibrosis contributes to the development of arrhythmias, we sought to investigate the effects of $\beta$-adrenoceptor blockade and central sympatholysis on interstitial changes following infarction in rats. The experiments also follow the observations 
in chapter 5 , which led us to propose that the (presumed) sympathetic component in the control of collagen changes is maximally activated in this model for heart failure.

Thus, in chapter 6 it was tested whether adrenergic blockade by means of the non-selective $\beta$-adrenergic receptor antagonist propranolol, or by means of the centrally acting sympatholytic agents clonidine or moxonidine, affects cardiac fibrosis and DNA synthesis after infarction in the rat.

We did not observe any significant effects of the $\beta$-blocker propranolol, nor of the centrally acting sympatholytic drugs clonidine and moxonidine on cardiac interstitial remodeling following myocardial infarction. In contrast, collagen content was increased after treatment with the above mentioned agents in shamoperated animals.

In conclusion, sympathetic inhibition does not affect fibrosis after infarction, possibly because of activation of the fibrotic process by other more dominant systems early after infarction. Similarly, interstitial cell proliferation is unaffected. Our data indicate that, in the early phase following inyocardial infarction, the sympathetic nervous system does not substantially contribute to the control of interstitial remodeling.

In chapter 7 the data obtained in the studies described in the previous chapters are discussed. 


\section{Samenvatting}

Hartfalen vormt een toenemend medisch probleem, niet alleen door de verbeterde behandeling van het acute hartinfarct, een van de belangrijkste oorzaken van hartfalen, maar ook door de vergrijzing van de bevolking. Beter inzicht in de pathofysiologie van het hartfalen biedt een rationele basis voor het ontwikkelen en toepassen van therapeutische maatregelen. In dit verband gaat tegenwoordig veel belangstelling uit naar neurohumorale systemen zoals het renine-angiotensine systeem en het sympatisch zenuwstelsel als mogelijke factoren die betrokken zijn bij de ontwikkeling van hartfalen. Een ander wijdverbreid concept is dat veranderingen in de structuur van het hart (in de angelsaksische literatuur 'cardiac remodeling' genoemd) een belangrijke rol spelen in de ontwikkeling van hartfalen. Daarbij zijn er veel aanwijzingen dat activatie van het renineangiotensine systeem en het sympatisch zenuwstelsel structuurveranderingen in het hart tot gevolg kan hebben.

Een beproefd experimenteel model voor hartfalen is het infarct-model bij de rat, waarin de veranderingen die optreden in de structuur van de hartspier uitgebreid zijn onderzocht. Het is gebleken dat in het niet-geïnfarceerde deel van het hart, naast hypertrofie van spiercellen, veranderingen optreden in het ondersteunende weefsel, het zgn. interstitium. Zo is in eerdere studies aangetoond dat in het interstitiun, na infarcering, de hoeveelheid collageen alsmede de DNA- synthese (een maat voor celproliferatie) toenemen in het niet-geïnfarceerde gedeelte van het hart.

Het doel van dit proefschrift is de regulatie van de veranderingen in het interstitium in het niet-geïnfarceerde deel van het myocard nader te onderzoeken, waarbij speciale aandacht wordt besteed aan het renine-angiotensine systeem en het sympathisch zenuwstelsel als mogelijke modulatoren van deze veranderingen.

Hoofdstuk 1 is een algemene introductie en biedt een overzicht van de literatuur aangaande structuurveranderingen in het myocard na een hartinfarct. Daarna volgt een beschrijving van het renine-angiotensine systeem en het sympatisch zenuwstelsel, waarbij met name wordt ingegaan op de invloed van deze systemen op de structuur van het hart. Aan het einde van het hoofdstuk worden de doelstelling en de liypothese van dit proefschrift beschreven. 
In hoofdstuk 2 werden de interstitiële cellen nader geïdentificeerd die na een infarct een verhoogde DNA-synthese laten zien. De celpopulatie van het interstitium bestaat voomamelijk uit fibroblasten en endotheelcellen. Een mogelijkheid om in dit model het aandeel van beide celtypen in de verhoogde DNA-synthese te bepalen is het zichtbaar maken van de microvasculatuur van het in paraffine ingebedde rattenhart en de DNA-synthese in deze microvaten te kwantificeren.

Hiertoe werd allereerst de geschiktheid van een aantal zgn. 'vasculaire markers' getest. De beste marker bleek Griffonia Simplicifolia I ("GSI", een lectine) te zijn. Een beproefde methode ter kwantificering van de DNA-synthese is het toedienen van 5-bromo-2'-deoxyuridine ("BrdU", een thymidine-analoog). De resulterende BrdU-incorporatie in het DNA wordt vervolgens zichtbaar gemaakt door deze te kleuren met behulp van een anti-BrdU-antilichaam. Door middel van een combinatie van GSI en BrdU, m.a.w. een dubbelkleuring, bleek het mogelijk de DNA-synthese in endotheelcellen van de microvasculatuur te bepalen.

De gevolgen van een infarct werden bepaald door een infarct te induceren middels onderbinding van de linker kransslagader. Schijn-geopereerde ratten (zelfde operatieprocedure zonder onderbinding) dienden als controle. Op deze manier werd aangetoond dat het grootste deel van de DNA-synthese in de ecrste twee weken na een infarct plaats vond in "niet-endotheelcellen", m.a.w. de fibroblasten. Een substantiëel gedeelte (ongeveer eenderde deel) van de totale DNA-synthese vond evenwel plaats in endotheelcellen van de microvasculatuur, hetgeen duidt op een verhoogde vaatgroei in het niet-geïnfarceerde deel van de linker ventrikel in de vroege fase na een infarct.

In hoofdstuk 3 werd de modulerende rol van het renine-angiotensine systecm op de interstitiële veranderingen nader onderzocht door, na inductie van een infarct, de effecten te bepalen van twee verschillende angiotensin-converting-enzyme ("ACE")-remmers, captopril en perindoprilaat, op de DNA-synthese in alle interstitiële cellen, en in de endotheelcellen.

Het bleek dat een vroege toediening van zowel captopril als perindoprilaat resulteerde in een remming van de na een infarct verhoogde totale DNA-synthese. Met behulp van de in hoofdstuk 2 ontwikkelde BrdU-GSI dubbelkleuring werd aangetoond dat alleen captopril een disproportionele remmende werking had op de DNA-synthese in endotheelcellen.

In een aparte studie werden de effecten van captropril op de maximale coronaire flow na infarcering onderzocht. In experimenten met geïsoleerde retrograad geperfundeerde rattenharten bleek dat zonder toediening van captopril de 
maximale flow binnen drie weken volledig normaliseerde. Vroege behandeling met captopril (vanaf dag 1 tot 21 na de operatie), maar niet late behandeling (vanaf dag 21 tot 35 ) bleek de normalisatie van de maximale coronaire flow bij de infarct-ratten te remmen. Concluderend wijzen deze resultaten erop dat een behandeling met captopril in de vroege fase na een hartinfarct de proliferatie van endotheelcellen en coronaire vaatgroei remt.

$\mathrm{Na}$ de vaststelling van de effecten van ACE-remming op de totale DNA-synthese en de DNA-synthese in endotheelcellen, beschrijft hoofdstuk 4 de effecten van specifieke blokkade van de angiotensine receptor subtype $1\left(\mathrm{AT}_{1}\right)$ en angiotensine receptor subtype $2\left(\mathrm{AT}_{2}\right)$.

De $\mathrm{AT}_{2}$-antagonist PD123319 gaf een significante daling van de totale DNAsynthese te zien. De $\mathrm{AT}_{1}$-receptor antagonist GR138950C daarentegen toonde geen effect op de DNA-synthese. Beide stoffen bleken geen verandering te induceren van de fractie van de DNA-synthetiserende endotheelcellen.

In parallelle experimenten werden de effecten van $\mathrm{AT}_{1}$ - en $\mathrm{AT}_{2}$-receptor blokkade op de hartfunctie onderzocht. Zonder medicamenteuze behandeling werd drie weken na inductie van een hartinfarct een afname van de hartfunctie waargenomen. Behandeling met PD123319 verminderde de reeds verslechterde hartfunctie nog meer, terwijl GR138950C geen effect had. Concluderend wijzen deze resultaten erop dat de toename van de DNA-synthese (door endotheelcellen en fibroblasten) na een hartinfarct - ten minste ten dele - wordt gemedieerd door de $\mathrm{AT}_{2}$-receptor. Bovendien suggereert de vermindering van zowel de interstitiële DNA-synthese als van de hartfunctie door $\mathrm{AT}_{2}$ - receptor blokkade, dat de geconstateerde hemodynamische effecten van $\mathrm{AT}_{2}$-receptor blokkade afhankelijk kunnen zijn van een reductie van de DNA-synthese door endotheelcellen en/of fibroblasten in het hỵpertrofe myocard.

Het is aannemelijk dat, naast het renine-angiotensine systeem, ook het sympatisch zenuwstelsel van invloed is op de structuur van het interstitium van de hartspier. Onbekend was echter of medicijnen die interfereren met het sympathisch zenuwstelsel effect hebben op de interstitiële structuurveranderingen in een vroege fase na een hartinfarct. In het kader van dit onderzoek werden de effecten bestudeerd van verschillende farmaca met ofwel een stimulerende (hoofdstuk 5), ofwel een remmende (hoofdstuk 6) adrenerge werking, zowel op de interstitiële DNA-synthese als op het collageengehalte in het niet-geïnfarceerde deel van het rattenhart 14 dagen na infarcering. 
In hoofdstuk 5 werden de effecten beschreven van adrenerge stimulatie door dobutamine (een $\alpha$ l- en $\beta$-adrenerge stof). In een parallelle studie werden de effecten van milrinon (een fosfodiësterase III-remmer) bepaald. Fosfodiësterase III-remming resulteert in de remming van de afbraak van de intracellulaire boodschapper cyclisch AMP (cAMP). Aldus wordt stimulatie van de $\beta$-adrenerge receptor nagebootst zonder dat er een adrenerge receptor aan te pas komt. Het collageengehalte werd morfometrisch bepaald door middel van meting van het relatieve collageenoppervlak van de niet-geïnfarceerde linker ventrikel. $\mathrm{Na}$ infarcering bleek het collageengehalte significant verhoogd, hetgeen resultaten van voorgaande studies bevestigt. De resultaten van de experimenten suggereren dat adrenerge stimulatie d.m.v. dobutamine -mogelijk via $\alpha$ l-adrenerge receptoren- de structuur van het cardiale interstitium beinvloedt middels additionele stimulatie van de DNA-synthese, maar geen invloed heeft op het collageengehalte na een hartinfarct. Bij schijn-geopereerde dieren induceerde dobutamine collageendepositie. Dit effect werd mogelijk ook gemedieerd door $\alpha 1$-receptoren, aangezien fosfodiësterase III- remming d.m.v. behandeling met milrinon geen significant effect had. Voorts zou de collageendepositie bij infarctdieren reeds maximaal gestimuleerd kunnen zijn.

Het gebruik van sympathicolytische geneesmiddelen vormt een belangrijk onderdeel van de behandeling van hartfalen. In klinische onderzoeken zijn gunstige effecten waargenomen van $\beta$-blokkerende medicijnen bij patiënten met hartfalen en/of een hartinfarct. Een van de verklaringen voor de verbetering van het klinisch beloop vormt de onderdrukking van ritmestoornissen door $\beta$ blokkade. Cardiale interstitiële fibrose wordt als een van de oorzaken van het ontstaan van ritmestoornissen aangemerkt. Op grond van deze overwegingen en de waarnemingen in hoofdstuk 5, waarin werd geopperd dat de (veronderstelde) sympatische component in de regulering van de collageendepositie maximaal geactiveerd zou kunnen zijn in het gebruikte model van hartfalen, zijn de experimenten met sympathicolytica uitgevoerd zoals beschreven in hoofdstuk 6 . Uit deze experimenten kwam naar voren dat $\beta$-adrenerge blokkade met propranolol geen effect had op de DNA-synthese en het collageengehalte 14 dagen na het induceren van een infarct. Hetzelfde gold voor de centraal werkende sympathicolytica clonidine en moxonidine. Bij schijn-geopereerde dieren bleek daarentegen het cardiale collageengehalte te zijn verhoogd na behandeling met elk van de drie sympathicolytica.

Concluderend blijkt remming van de sympathicus geen meetbare invloed te hebben op de fibrose in het niet-geinfarceerde deel van het hart. Waarschijnlijk 
treedt activatie van het fibrotische proces in de vroege fase na een infarct op onder invloed van andere dominante systemen. $\mathrm{Al}$ met al wijzen de resultaten van de experimenten met diverse sympathicolytica erop dat het sympatisch zenuwstelsel in de vroege fase na een infarct geen substantiële bijdrage levert aan de regulering van de onderzochte interstitiële structuurveranderingen.

Ter afronding wordt in hoofdstuk 7 een beschouwing gegeven van de in voorafgaande hoofdstukken gepresenteerde resultaten. 


\section{Curriculum vitae}

\section{Martina Cornelie Kuizinga}

12 maart 1961

1973-1979

1979-1980

1980-1988

nov. 1986

apr. 1988

sept. 1988- okt. 1989

nov. 1989- apr. 1991

apr. 1991-okt. 1994

nov. 1994- mei 1995

juni 1995-heden
Geboren te ‘s Gravenhage.

Gymnasium Sorghvliet te 's Gravenhage en Het Baarnsch Lyceum te Baam. Eindexamen VWO: talen en biologie.

Avondcursus bij de Stichting Aanvullend Onderwijs te Utrecht, waarna staatsexamen natuurkunde en scheikunde.

Studie geneeskunde aan de Rijksuniversiteit Utrecht.

Doctoraal examen geneeskunde.

Artsexamen.

AGNIO pathologische anatomie, Westeinde Ziekenhuis te "s Gravenhage.

B-opleiding pathologie in het St. Elisabeth Ziekenluis te Tilburg (Opleider J.F.M.M. Miseré).

Opleiding pathologie, Academisch Ziekenhuis Maastricht. Opleider Prof.dr. J.W. Arends.

Staflid afdeling pathologie Academisch Ziekenhuis Maastricht.

Staflid Pathologisch Anatomisch Laboratorium Dordrecht e.o. 


\section{List of publications}

Kuizinga MC, Smits JFM, Arends JW, Daemen MJAP: AT2 receptor blockade reduces cardiac interstitial cell DNA synthesis and cardiac function after rat myocardial infarction. J Mol Cell Cardiol 1998;30:425-434.

Nelissen-Vrancken HJMG, Kuizinga MC, Daemen MJAP, Smits JFM: Early captopril treatment inhibits DNA synthesis in endothelial cells and normalization of maximal coronary flow in infarcted rat hearts. Cardiovasc Res 1998;40:156164 .

Smits JFM, Passier RCJJ, Nelissen-Vrancken HJMG, Cleutjens JPM, Kuizinga MC, Daemen MJAP: Does ACE inhibition limit structural changes in the heart following myocardial infarction? Fiur Hecort .J 1995; 16(Suppl.N):46-51.

Gans ROB, Kuizinga MC, Goldschmeding R, Assmann K, Huysmans FT, Gerlag PG, Donker AJ, Iloomtje SJ: Clinical features and outcome of patients with glomerulonephritis and antineutrophil cytoplasmic autoantibodies. Nephron 1993;64:182-188.

Roukema JA, Leenen LPH, Kuizinga MC, Maat B: Angiosarcoma of the irradiated breast: a new problem after breast conserving therapy? Neth .I Surg 1991;43:114-116.

Goldschmeding R, Cohen-Tervaert JW, Gans ROB, Dolman RM, Van den Ende ME, Kuizinga MC, Kallenberg CG, V.d.Borne AE: Different immunological specificities and disease associations of c-ANCA and p-ANCA. Neth $J$ Med 1990;36:114-116.

(ians ROB. Goldscluneding R, Donker AJM, Hoontje SJ, Kuizinga MC, Cohen Tervaert JW, Kallenberg JCM, V.d. Borne AEG: Neutrophil cytoplasmic alutuantibodies and Wegener's granulomatosis. I.unc't 1989;1:269-270. 


\section{Abstracts}

Nelissen-Vrancken HJMG, Kuizinga MC, Raes EA, Daemen MJAP, Smits JFM: Captopril inhibits vessel growth and endothelial cell proliferation in rat hearts with myocardial infarction. Circulation 1996;94(Suppl.):I126.

Nelissen-Vrancken HJMG, Kuizinga MC, Raes EA, Daemen MJAP, Smits JFM: Early and not late captopril treatment inlibits vessel growth and endothelial cell proliferation in rat hearts with myocardial infarction. Hypertension 1996;28:697.

Kuizinga MC, den Brok ЛL, Smits JFM, Arends JW, Daemen MJAP: Het sympathicomimeticum dobutamine stimuleert interstitiële myocardiale DNAsynthese na inductie van een myocardinfarct bij de rat. Ned Tijdschr Geneesk $1994 ; 138: 2028$.

Kuizinga MC, Cleutjens JPM, Smits JFM, Daemen MJAP: DNA-synthese van myocardiale interstitiele cellen na een myocardinfarct: evaluatie met behulp van een dubbelkleuring. Ned Tijdschr Geneesk 1992;137:1172-1173.

Kuizinga MC, Cleutjens JPM, Smits JFM, Daemen MJAP: Griffonia simplicifolia I (GSI): a suitable rat cardiac microvascular marker on paraffin embedded tissue. J Mol Cell Cardiol 1992;24(Suppl.V):S57.

Gans ROB, Kuizinga MC, Huysmans F, Gerlag PGG, Hoorntje SJ: Favorable outcome of rapidly progressive glomerulonephritis (RPGN) in systemic vasculitis with anti-neutrophil cytoplasmic autoantibodies (ANCA). Kidncy Int $1989 ; 35: 226$. 



\section{Dankwoord}

Velen hebben in de achterliggende jaren rechtstreeks of indirect bijgedragen aan de totstandkoming van dit proefschrift. Hen allen wil ik hier op schrift (nogmaals) bedanken. Zonder aan anderen tekort te willen doen noem ik een aantal van hen bij name.

Mijn dank gaat in de eerste plaats uit naar mijn beide promotors, de hoogleraren dr.M.J.A.P. Daemen en dr.J.F.M. Smits. Een buitengewoon duo, dat blééf geloven in de totstandkoming van dit boek.

Zonder hun optimisme, creatieve en voortvarende begeleiding zou het er nog niet zijn geweest. Beste Mat en Jos, bijzonder hartelijk bedankt!

Dr.H.J.M.G. Nelissen-Vrancken, beste Majorie, uiteraard is een prominente plaats in dit dankwoord ingeruimd voor jou. Veel experimentele arbeid en denkwerk heb je verricht voor het derde hoofdstuk. Bedankt voor de zeer prettige samenwerking.

Prof.dr. J.W. Arends, beste Jan Willem, jou ben ik veel dank verschuldigd voor je betrokkenheid en stimulerende invloed van het begin af aan. Aan jou heb ik te danken dat je voor mij voorwaarden schiep om dit onderzoek tijdens en na mijn opleidingstijd te doen. Ook ben ik je erkentelijk voor je bijdrage als lid van de beoordelingscommissie.

De andere leden van de beoordelingscommissie, de hoogleraren dr.M. Borgers en dr.H.A.J. Struijker Boudier, wil ik graag bedanken voor het kritiscl doomemen en beoordelen van het manuscript.

Prof.dr.W. Schaper and Prof.dr.K.T. Weber, I would like to thank you for reading the manuscript of this book.

Allen die destijds met mij deel uitmaakten van de cardiovasculaire onderzoeksgroep wil ik bij deze bedanken voor de ondersteuning en de gemoedelijke en gezellige werksfeer.

Dr.ir. J.P.M. Cleutjens, beste Jack, jij was een immer bereidwillige vraagbaak voor mij, en je hebt op vele manieren energie gestoken in dit project. Je hebt je bezig gehouden met de collageenmetingen van hoofdstuk 5 en 6 . Verder heb je onder andere veel dierexperimenteel werk verricht. 
Petra Aarts, Annique Janssen, Birgit Engelen, Monique Verluyten, vele bewerkingen, kleuringen, en metingen kwamen voor jullie rekening. Jullie gingen door tot het optimaal te bereiken resultaat.

Cor Beek, jij wist altijd wel weer snel gelegenheid te vinden om mij verder op weg te helpen met allerlei zaken, waaronder statistische bewerkingen en de regelmatige toezending van CCOD-schijfjes.

In dit onderdeel van mijn dankwoord wil ik natuurlijk mede betrekken:

dr.M G.(Miek) Havenith, dr.S.(Sylvia) Heeneman, dr.ir.E.M.(Ellen) van Kleef, dr. R.C.J.J. (Robert) Passier en dr.M.M.W. (Magda) Ulrich.

De afdeling Farmacologie ben ik veel dank verschuldigd voor de experimentele ondersteuning. Het team bestaande uit Jacques Debets, Peter Leenders, Carolien Eerdmans en Flsbeth Raes wil ik graag bedanken voor het verrichten van de vele operatics en metingen.

Een drietal uitstekende student-assistenten, Jan den Brok, Bas Verhoeven en Ruth Fleischeuer, hebben het onderzoekswerk aanmerkelijk verlicht. Jan den Brok, dank je wel voor je haast niet te stuiten inzet, speciaal voor je bijdrage aan hoofdstuk 5. Bas Verhoeven en Ruth Fleischeuer, zeer bedankt voor jullie volhardend optimisme en inspanningen ten behoeve van het onderzoek.

Alle medewerkers van de afdeling pathologie in Maastricht dank ik voor de prettige onderlinge contacten tijdens mijn opleiding en onderzoek.

Margriet Pijls en Annick Moors, vele uren heb ik mogen doorbrengen op jullie "immunolab". Dank voor al jullie hulp!

Het is een genoegen om, op mijn beurt, de collega arts-assistenten in die tijd, dr.A.A.M.(Anneke) van der Wurff, dr.J.E.(Evan) Boers, dr.S.(Prapto) Sastrowijoto en dr.I.E.M.G.(Ingtid) Willems, te kunnen bedanken voor hun collegialiteit en gezelligheid.

Ik prijs mij gelukkig thans als patholoog te zijn verbonden aan het Pathologisch Anatomisch Laboratorium Dordrecht. Mijn collega's, R.J.(Robert) Heinhuis, dr.A.M.(Mieke) Jonker, G.P.(Paul) Lauw, dr.A.W.F.M. (Antoine) van Leeuwen, A.C.F.(I.ex) Makkus, dr.A.H.(Dries) Mulder, J.(Janneke) Visser, dr.P.J.(Pieter) Westenend, alsmede P.(Peter) Melkert dank ik voor hun betrokkenheid en uitzonderlijk te noemen flexibiliteit. Alle medewerkers van het lab dank ik eveneens hartelijk voor hun medeleven en belangstelling. 
Marianne Y. Naerebout, dank je wel dat je je artistieke creativiteit hebt willen inzetten ten behoeve van de omslag van dit boek.

Sjors Beens, ondanks jouw drukke werkzaamheden stond je erop de layout te verzorgen. Lian Nijland wil ik eveneens graag bedanken voor haar bijdrage aan de layout.

Voor de steun die ik -door de jaren heen- mocht ondervinden van familie, vrienden en bekenden ben ik zeer dankbaar. Het immer 'open huis' en de niet aflatende ondersteuning van mijn ouders hadden en hebben een weldadig effect en betekenen veel voor mij. In de schrijffase heeft mijn omgeving geholpen de laatste loodjes een stuk lichter te maken. Allen veel dank hiervoor! Het dagelijks contact met mijn broer en 'persoonlijke coach' Wolter Kuizinga heeft uitermate stimulerend gewerkt. En ook Arie Bijl wil ik in het bijzonder bedanken voor zijn support.

Tot slot is het eigenlijk onmogelijk om Sjors in dit dankwoord te bedanken in bewoordingen die recht doen aan zijn aandeel. Lieve Sjors, als geen ander heb jij ook de keerzijde van dit project ervaren. Altijd, van (voor) het begin tot het einde was jij er voor mij. Daarvoor heel veel dank - en voor ál het andere. 
